\title{
정책방안
}

A Study on the Current Trend of

Youth Tourism and Policy Measures

to Revive Domestic Tourism 



\section{국내관광 활성화를 위한 청년관광 실태 분석 및 정책방안}

A Study on the Current Trend of Youth Tourism and Policy Measures to Revive Domestic Tourism

신용석·강현수 

연구책임

신용석 한국문화관광연구원 부연구위원

강현수 한국문화관광연구원 연구원 

국내관광 활성화를 위한 청년관광 실태 분석 및 정책방안

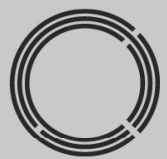

연구개요 



\section{1. 서론}

\section{가. 연구 배경 및 목적}

1) 연구 배경

- 문재인 정부는 “심표가 있는 삶, 사람이 있는 관광”이라는 관광 슬로건을 제시, 생 애주기별·계층별 관광정책으로 전환하여 과거의 양적·경제적 성과중심에서 벗어 나 국민, 지역주민, 방한 관광객 등 사람 중심의 질적 정책을 추진하였음

- 생애주기별 관광지원 체계 구축을 위해서 각 주기별에 맞는 맞춤형 정책을 수립하여 수요자 지향형 정책 추진을 위해 국내관광 활성화와 지역관광 자원개발을 도모함

- 본 연구의 대상인 청년층은 해외여행 참여와 선호도가 높아 국내관광에는 상대적 으로 낮은 관심으로 여행수지 불균형 심화 요인으로 작용하였으며, 저비용 항공 도입과 글로벌 OTA 진출은 이를 가속화하였음

- 반면, 2020년 코로나19 발생으로 청년층 여행 패턴은 큰 변화를 가져와 국내여행 이 활발해지고 지역관광에도 새로운 바람이 불고 있으므로 이를 유지, 확대하기 위해 현 상황에 대한 체계화는 정책 자료로 활용할 수 있음

- 특히, 국내관광과 해외관광은 대체제의 관계가 아니므로 향후 코로나19 종식 후 청년층의 해외여행 재개가 시작되더라도 국내여행과 해외여행의 적절한 균형을 위 해 우리나라 청년관광 정책 수립 필요성이 요구됨

\section{2) 연구 목적}

- 본 연구의 목적은 전술한 연구배경에 따라 국내관광 활성화를 위해 우리나라 청년 관광의 실태를 분석하고 청년관광에 관한 정책 방향을 제시하는 데 있음

- 국내외의 청년 개념 및 정책대상의 범위를 규정, 청년세대와 $\mathrm{MZ}$ 세대의 관계 및 특징을 파악하고 $\mathrm{MZ}$ 세대의 문화소비특징과 여행 특성을 파악함

- 우리나라 청년관광 현황 및 특성을 분석하고 이들의 국내여행 동향 및 행태 파약함 - 국내외 청년관광의 정책현황 및 사례를 분석하고 문제점을 도출하여 해당 정책 수립 근거로서 정책 기초 자료를 제공함 


\section{나. 연구 범위 및 방법}

\section{1) 연구 범위}

- 본 연구에서는 청년의 개념 및 정책대상의 범위, 청년관광의 의의, $\mathrm{MZ}$ 세대와 청년 관광, 청년관광 현황 및 특성 분석, 청년관광 국내외 정책현황 및 시례, 종합분석 및 정책제언 등을 내용적 범위로 함

〈표 1〉연구의 내용적 범위

\begin{tabular}{|c|c|}
\hline 구분 & 주요 내용 \\
\hline $\begin{array}{l}\text { 청년의 개념 및 } \\
\text { 정책대상의 범위 }\end{array}$ & $\begin{array}{l}\text { - 청년의 정의와 정책대상으로서의 범위에 대한 국내외적 추세 } \\
\text { - 우리나라 정책대상에서 청년범위와 본 연구에서의 의미 }\end{array}$ \\
\hline 청년관광의 의의 & $\begin{array}{l}\text { - 청년관광과 개인발달의 관계 } \\
\text { - 관광산업 관점에서 청년관광이 갖는 의의 }\end{array}$ \\
\hline $\begin{array}{l}\mathrm{MZ} \text { 세대와 } \\
\text { 청년관광 }\end{array}$ & $\begin{array}{l}\text { - 청년세대와 } \mathrm{MZ} \text { 세대의 관계 및 특징 } \\
\text { - } \mathrm{MZ} \text { 세대의 문화소비특징과 여행특성 }\end{array}$ \\
\hline $\begin{array}{l}\text { 청년관광 현황 및 } \\
\text { 특성 분석 }\end{array}$ & $\begin{array}{l}\text { - 국민여행조사 원자료 분석을 통한 청년층 국내관광 실태 분석 } \\
\text { - 표적집단면접, 청년층 설문조사 등을 통한 청년층의 국내여행 행태 및 특성 분석 }\end{array}$ \\
\hline $\begin{array}{l}\text { 청년관광 국내외 } \\
\text { 정책현황 및 사례 }\end{array}$ & $\begin{array}{l}\text { - 우리나라 청년관광 정책현황 및 사례 } \\
\text { - 외국 청년관광 정책현황 및 사례 (일본) }\end{array}$ \\
\hline $\begin{array}{l}\text { 종합분석 및 } \\
\text { 정책제언 }\end{array}$ & $\begin{array}{l}\text { - 연구결과 종합분석을 통한 국내여행 활성화를 위한 } \\
\text { - 청년관광 정책제시 }\end{array}$ \\
\hline
\end{tabular}

\section{2) 연구 방법}

- 연구 수행 방법은 (1) 문헌조사, (2) 전문가 조사(델파이), (3) 설문조사 및 정성적 분석(FGI) 실시 등 크게 세 가지로 정리할 수 있음 
[그림 1] 연구 흐름도

\begin{tabular}{|c|c|c|}
\hline 구 분 & 연구 내용 & 연구 방법연구방법 \\
\hline 서론 & $\begin{array}{l}\text { - 연구 배격 ㅁㅣㅣ 목ㅈㅓㅓ 설정 } \\
\text { - 연구 내용 및 방법 }\end{array}$ & $\begin{array}{l}\text { - 문헌연구 } \\
\text { - 관련자료 검토 }\end{array}$ \\
\hline $\begin{array}{c}\text { 청년과 } \\
\text { 청년관광 }\end{array}$ & $\begin{array}{l}\text { - 청년의 개념 및 정책대상 범위 } \\
\text { - 청년계층과 } \mathrm{MZ} \text { 세대 } \\
-\mathrm{MZ} \text { 세대특징 및 여행특성 }\end{array}$ & $\begin{array}{l}\text { - 관련자료 수집 } \\
\text { 및 분석 } \\
\text { - 문헌연구 }\end{array}$ \\
\hline $\begin{array}{c}\text { 청년관광 현황 및 } \\
\text { 특성 분석 }\end{array}$ & $\begin{array}{l}\text { - 우리나라 청년층 국내여행 현황 } \\
\text { - 여행 동향 및 특성 } \\
\text { - 여행 행태 } \\
\text { - 제약요인 } \\
\text { - 여행 소비 } \\
\text { - 여행정보 경로 } \\
\text { - 관심사항 등 }\end{array}$ & $\begin{array}{l}\text { - 국민여행조사 } \\
\text { 심층 분석 } \\
\text { - 표본설문조사 } \\
\text { - 표적집단면접 }\end{array}$ \\
\hline $\begin{array}{c}\text { 첫년관광 } \\
\text { 국내외 정책현황 }\end{array}$ & $\begin{array}{l}\text { - 우리나라 청년관관 정책현황 검토 } \\
\text { - 일본 청년관놩 정hㅐㄱㅅㅖ 검토 }\end{array}$ & $\begin{array}{l}\text { - 문헌조사 및 } \\
\text { 전문가 자문 }\end{array}$ \\
\hline 청년관광 활성화 방안 & $\begin{array}{l}\text { - 국내관광 활성화를 위한 청년관광 정책방향 } \\
\text { 및 주요과제 제시 }\end{array}$ & - 연구 종합 \\
\hline
\end{tabular}




\section{2. 청년과 청년관광}

\section{가. 청년의 개념 및 정책범위}

- 국가별 상황과 정책 목적에 따라 연령 범위가 유동적인 특징은 보이지만 일반적으 로 하한연령은 법정 최소 학교졸업 연령과 관련이 있으며 상한연령은 대학졸업 연 령과 관련 있음

- 청년 범위에 대한 국제적 기준은 경제협력개발기구(OECD)와 국제연합(UN)에 의 한 것으로 이들은 만 15 세부터 만 24 세까지를 청년으로 규정, 해외의 경우 청년들 의 경제 상황이 열악할수록 그 대상적 범위를 확대하는 경향을 보임

- 우리나라「청년기본법」에서는 청년을 '19세 이상 34 세 이하인 사람으로(다만, 다 른 법령과 조례에서 청년에 대한 연령을 다르게 적용하는 경우에는 그에 따를 수 있다.)' 정의하고 있으며, 「청년고용촉진 특별법」에서는 “청년이란 취업을 원하는 사람으로서 대통령령으로 정하는 나이에 해당하는 사람”으로 15세 39세까지로 규정함

〈표 2〉우리나라 청년의 정의 사례

\begin{tabular}{c|c}
\hline 출처 & \multicolumn{1}{c}{ 정의 } \\
\hline 표준국어대사전 & 1. 신체적 · 정신적으로 한창 성장하거나 무르익은 시기에 있는 사람, 2. 성년 남자 \\
\hline 청년기본법 & $\begin{array}{l}\text { 19세 이상 34세 이하인 사람(다만, 다른 법령과 조례에서 청년에 대한 연령을 다르게 } \\
\text { 적용하는 경우에는 그에 따를 수 있음) }\end{array}$ \\
\hline 청년고용촉진특별법 & 청년이란 취업을 원하는 사람으로서 대통령령으로 정하는 나이1)에 해당하는 사람 \\
\hline
\end{tabular}

자료: 연구자 정리

1) “대통령령으로 정하는 나이에 해당하는 사람"이란 15 세 이상 29 세 이하인 사람을 말한다. 다만, 법 제 5 조 제1항에 따라 「공공기관의 운영에 관한 법률」에 따른 공공기관과 「지방공기업법」에 따른 지방공기업이 청 년 미취업자를 고용하는 경우에는 15 세 이상 34 세 이하인 사람을 말한다. (청년고용촉진 특별법 시행령 제2조) 


\section{나. 청년관광의 의의}

1) 청년관광과 개인발달

- 청년은 여행의 욕구가 가장 왕성한 시기로서 여행으로 대표되는 관광활동은 청년 의 자아발전과 개인의 정체성 형성 등 개인적 발달(Personal development)에 긍 정적 영향을 끼침

- 특히 현대사회에서 여행은 청년들의 주요한 생활양식으로서 문제해결력, 문화교류 를 통한 성장의 계기로 작용하며 성인기에 들어선 청년이 자율적으로 여행지 선택 과 일정을 계획하기 때문에 인적 발달에 더 큰 영향력을 미침

2) 청년관광과 관광사업

- UNWTO \& WYSE (2011)의 보고서에 따르면 국제관광시장에서 청년관광시장 (Youth Travel Market) 은 2014년 약, 2,860억 달러 규모에서 2020년 약 4,000 억 달러로 증가할 것을 예상함

- 청년관광은 긴 여행기간의 특징으로 평균적으로 더 큰 소비액을 보이며 경제적 이 유로 게스트하우스나 호스텔 등 지역 내에서 직접적 소비가 이루어짐

- 반면, 청년여행자는 모험을 추구하고 위험을 감수하는 특징에 따라 국내보다는 국 제관광시장에서 주목받고 있으며 우리나라 20 30대의 경우에도 다른 세대에 비 해 해외여행 선호도가 높게 나타남

\section{다. 청년관광과 $\mathrm{MZ}$ 세대}

- $\mathrm{MZ}$ 세대의 특징은 어린시절부터 디지털 환경에 노출되어 신기술에 거부감이 없으 며 온라인 탐색과 정보를 적극 활용하는 특징을 보이며 개인, 일과 휴식의 균형을 중요시하며 개인의 취향을 존중함

- 소득적 측면에서 이전 세대들보다 경제적 구매력은 낮게 평가되며 생필품 등에는 가성비를 중요시하지만, 취미나 문화생활과 같은 본인의 만족을 위한 소비에는 적 극적인 이중적 행태를 보이며 현재의 행복에 충실한 특징을 나타냄 
- $\mathrm{MZ}$ 세대의 이러한 특성은 여행 활동에도 반영되어 문화관광지를 선호하고 동시에 새로운 여행지를 발굴하는 적극적인 여행자로 나타남.

- 여행 계획 시에도 디지털 매체를 적극 활용하여 여러 채널(네이버, 유튜브, 인스타 그램, 구글 등)을 동시 이용하고, 여행 과정을 본인의 SNS 에 기록하여 지인들과 공유하여 여행의 시작과 끝이 SNS를 통해 이루지고 있음

- 코로나19로 인해 MZ세대는 국내여행을 통해 여행욕구를 해소하고 있음

\section{라. 소결}

- 청년에게 청년관광의 의의는 두 가지 측면에서 고찰할 수 있는데 첫째, 개인 발달 (personal development)이며 둘째는, 관광산업적 측면에서의 청년관광의 잠재 력임

- 첫째, 개인 발달(personal development)의 경우 자기 주도적 여행계획과, 여행 지에서의 새로운 경험, 문제 해결을 통한 자아형성과 인격성숙의 긍정적 영향을 받아 개인발달의 기제(機制)로 작용할 수 있음

- 둘째, 관광산업적 측면에서 국제관광 부문에 편중되었던 평가와 청년층의 선호도 가 코로나19를 계기로 청년층의 국내관광에 대한 관심 및 활동 증가에 주목할 필 요성 증가함

- $\mathrm{MZ}$ 세대의 특징이 반영된 문화체험, 동적 레포츠, 스토리가 결합된 장소 매력성이 있는 새로운 여행지에 대한 적극적 발굴이 시급함. 또한, SNS와 온라인 콘텐츠 활 용에 적극적인 행태를 보이며 여행 트렌드를 주도하는 트렌드 리더활동에 주목할 필요가 있음 


\section{3. 청년관광 현황 및 특성}

\section{가. 청년관광 현황 및 특성 분석 개요}

- 3장에서는 청년층의 국내관광 현황과 특성을 분석함으로써 청년관광 및 국내관광 활성화 방안 수립의 근거가 되는 기초자료를 제시하고자 하였음

- 이를 위해 일차적으로 국민여행조사 원자료를 분석하여 청년층의 국내관광 실태를 검토하였음

- 두 번째 단계는 청년관광 표적집단면접 조사로서 국민여행조사 원자료 분석 결과 를 바탕으로 청년층의 국내관광 인식 및 행태를 다각적으로 살펴봄

- 마지막 단계는 상기 검토 과정을 통해 드러난 청년층의 국내관광 특성을 바탕으로 청년층 국내관광 특성을 심층 조사하기 위한 조사계획을 수립하고 구조화된 설문 지를 통해 온라인 조사를 실시함

[그림 2] 청년관광 현황 및 특성분석 절차

\begin{tabular}{|c|c|}
\hline 구분 & 주요 내용 \\
\hline $\begin{array}{l}\text { 국민여행조사 } \\
\text { 원자료 분석 }\end{array}$ & - 국내 청년층(만 19세-34세)의 전반적인 국내관광 현황 및 행태 분석 \\
\hline $\begin{array}{l}\text { 청년층 } \\
\text { 표적집단면접 조사 } \\
\text { (미혼자,기혼자/ } \\
\text { 경제활동 여부) }\end{array}$ & $\begin{array}{l}\text { - 국민여행조사 분석 결과를 바탕으로 청년층 대상 } \mathrm{FGI} \text { 실시 } \\
\text { - 결혼 및 자녀 유무, 경제활동 여부(학생, 직장인 등)에 따라 세부 그룹을 } \\
\text { 편성하여 면접조사 실시 } \\
\text { - 청년층의 국내관광 인식 및 행태, 세분 집단별 특성을 다각도로 검토 }\end{array}$ \\
\hline $\begin{array}{l}\text { 청년층 국내관광 } \\
\text { 특성 심층조사 }\end{array}$ & $\begin{array}{l}\text { - 청년층(만 19세-34세) 대상 국내관광 특성 심층조사 실시 } \\
\text { - 온라인 조사, 표본 수 } 1,000 \text { 명 } \\
\text { - 청년층의 관광 행태, 국내관광 제약 요인, 청년관광 지원정책 인식 및 } \\
\text { 수요 등 조사 }\end{array}$ \\
\hline $\begin{array}{l}\text { 종합 분석 및 } \\
\text { 시사점 도출 }\end{array}$ & $\begin{array}{l}\text { - 청년층의 국내관광 행태, 제약요인, 평가 및 개선사항 등 청년관광 활성 } \\
\text { 화 방안 도출을 위한 청년층 관광특성(세분집단)별 종합분석 }\end{array}$ \\
\hline
\end{tabular}




\section{나. 종합 분석}

1) 국내관광 시장에서 청년층의 의미

- 해외여행을 선호하나 전체적인 여행 참여 빈도가 높으며 국내관광 시장을 주도하 는 계층으로 전체 국민과 비교해 1 인 평균 여행 횟수, 1 인 평균 여행 일수, 1 인 평균 여행지 지출 등이 높은 것으로 나타나고 있음

- 코로나19 확산의 영향으로 국내관광 활동의 크게 위축된 상황에서도, 관광여행 중 심의 국내관광 활동을 지속적으로 이어가는 등 코로나 19 이후 국내관광 시장 회복 을 주도해 나갈 핵심 계층으로 평가됨

- 특히, 청년층 내에서도 여성, 30대 이상, 전업주부, 주5일 근무제 시행 사업장의 직장인, 기혼 및 자녀동반 가구 등은 국내관광 활동을 활발히 영위하고 있는 세분 집단으로 확인됨

- 반면, 코로나 19 이후 경제활동, 직업, 가구형태 등에 따른 세분집단별로 국내관광 활동에 있어서 차별적인 행태를 보임

- 특히 경제활동을 영위하지 않는 청년층의 경우 국내여행 향유 경험의 격차 확대를 보이 므로 향후 정책방향 설정 시, 청년층 내 세분집단별 차이가 면밀히 고려되어야 함

\section{2) 청년층의 국내관광 행태}

- 청년층의 국내관광 행태는 일반적으로 전체 국민과 유사한 것으로 확인되었으나 여행 정보 획득 경로, 동반자 수 및 유형, 여행지 활동, 이동 수단, 여행상품의 구 매 행동 등에서 청년층만의 독특한 특성이 나타남

- 여행정보 획득 경로에 있어서 청년층은 '인터넷 사이트/모바일 앱’에 대한 활용도 가 높으며, 포털사이트, $\mathrm{SNS}$, 동영상 사이트에 대한 선호가 높은 것으로 확인됨

- 또한 페이스북, 인스타그램 등에서 공유할 수 있는 사진과 해시태그로 구성된 SNS 콘텐츠와 같이 특정 유형의 정보에 대한 수요가 높으며, 다수의 청년층이 국내여행 후 관련 정보를 디지털 매체를 통해 공유(재생산) 하는 등 일반적인 국민들의 정보 활용 행태와 차별화 되는 특성을 보임 
- 여행 활동에 있어서 청년층은 자연 및 풍경 감상과 같이 일반적으로 선호되는 활동 뿐만 아니라 ‘시티투어', ‘테마파크, 놀이시설, 동/식물원 방문' 등 체험활동에 보 다 적극적으로 참여하는 특징을 보임

- 심층면접조사에서도 체험활동을 특정 관광 목적지 방문의 핵심 동기이자 지역에 대한 주기적인 재방문 이유로 설명함

- 청년층의 주요 이동 수단은 빠르고 쉽게 이동 가능하며 자유로운 여행이 가능한 자가용으로 나타났으나, 주로 경제적인 요인에 의해 '고속/시외/시내버스', '지하 철, '철도' 등 대중교통을 이용률이 상대적으로 높았음

- 청년층의 여행상품 이용 시 전체 국민대비 높은 사전 예약률을 보이고 있음. 이들 은 숙박비에 대한 부담을 가장 크게 느끼고 있으며, 시설 예약은 야놀자, 호텔스닷 컴 등의 숙박예약 플랫폼에서 가장 빈번히 이루어졌으며 시설 선택 시에는 비용/ 가격, 위생 등을 주로 고려함

- 청년층의 국내여행 시 동반자수는 다소 적은 것이 특징이며 주로 '친구/연인', '가 족' 등 개인적인 관계 내에서 동반 여행이 이루어지고 있으며 혼자 여행하는 비율 도 상당수를 차지하는 것으로 나타남

3) 청년층의 국내관광 제약

- 청년층의 국내관광 제약요인으로는 여행할 시간의 부족과 관광 인프라가 부족, 경 제적 여유부족 등이 주된 요인

- 특히 숙박비에 대한 부담을 가장 크게 느끼며 경제활동을 하지 않는 청년층의 경우 부모/친척 등으로부터 여행경비를 지원 받는 경우가 상대적으로 높은점을 고려하 여 청년층의 국내관광을 활성화하기 위한 경제적 유인의 제공이 고려되어야 함

4) 국내여행 평가 및 개선사항

- 청년층의 과반 이상은 국내여행에 대해 안전하고, 다른 손님과 공평하게 대접 받으 며, 편의시설, 관광 종사자의 서비스, 여행 인프라가 적절하다고 평가함 
- 반면, 가격, 여행상품 구성, 콘텐츠에 대해서는 상대적으로 낮게 평가함

- 청년층은 국내여행 활성화를 위한 개선 요인으로 상품개발, 서비스, 인프라 등에 대한 개선을 우선순위로 꼽았고, 개선의 주체로는 인프라 구축은 공공, 서비스 및 상품개발 개선은 민간을 선정함

- 청년층의 국내여행 활성화를 위해 필요한 정부 추진 정책은 바가지 요금 개선, 근 로자 휴가지원사업 확대, 주52시간 근무제 등 유연근무제 확대 시행 등이 우선순 위로 선정됨

- 대학(원)생은 '대학(원)생 여행경비 지원', 자녀동반 가구에서는 '유아동반 관광객 편의시설 확충'에 대한 선호가 높아 정부 정책 방향 설정 시 생애주기별 특성을 고려한 정책방안을 모색할 필요성이 있음

\section{4. 청년관광 정책현황 및 사례}

\section{가. 우리나라 청년관광 정책과 사례}

1) 청년관광 정책의 배경과 흐름

- 우리나라의 청년정책은 청년의 일자리 창출에 중점을 두고 시작되었기 때문에 청 년관광정책도 일자리 창출을 목적으로 하였으나 관광산업 특성상 제조업처럼 전문 기술 교육 등이 여의치 않아 창업 독려에 중점을 두어왔음

- 최근 문재인 정부에서 청년정책의 범위를 단순히 일자리 창출에서 벗어나 청년의 삶 전반으로 확대하면서 청년관광정책에서도 창업 이외 청년관광 수요 진작을 통 한 국내관광 활성화에도 관심을 가지기 시작함

2) 우리나라 청년관광 정책 사례

- 문화체육관광부 현재 국내관광 활성화를 위해 실시하고 있는 청년관광 정책사업으 로 청년관광 공모전(트래블리그), 청년층 갭이어(Gap Year), 대학생 유튜브 기자 단(트래블리더.mov)' 의 세 가지가 정책사업이 운영 중에 있음 
- 이 사업들은 한국관광공사가 사업 실무를 담당하여 진행하고 그 내용과 방식은 주 로 청년들에 의한 여행 콘텐츠 개발과 그 내용을 다양한 $\mathrm{SNS}$ 채널 등을 통하여 홍보하고 있음

- 이 사업들의 장점은 $\mathrm{MZ}$ 세대의 특성에 맞추어 SNS 채널과 유투브를 통한 홍보 채널 등의 방식이 적정하다는 점이지만, 한계점으로는 동 사업들의 예산이 너무 적고 모두 홍보 마케팅 사업에 한정되어 있음

[그림 3] 청년층 갭이어 여행콘텐츠 SNS 홍보 사례(2020년)

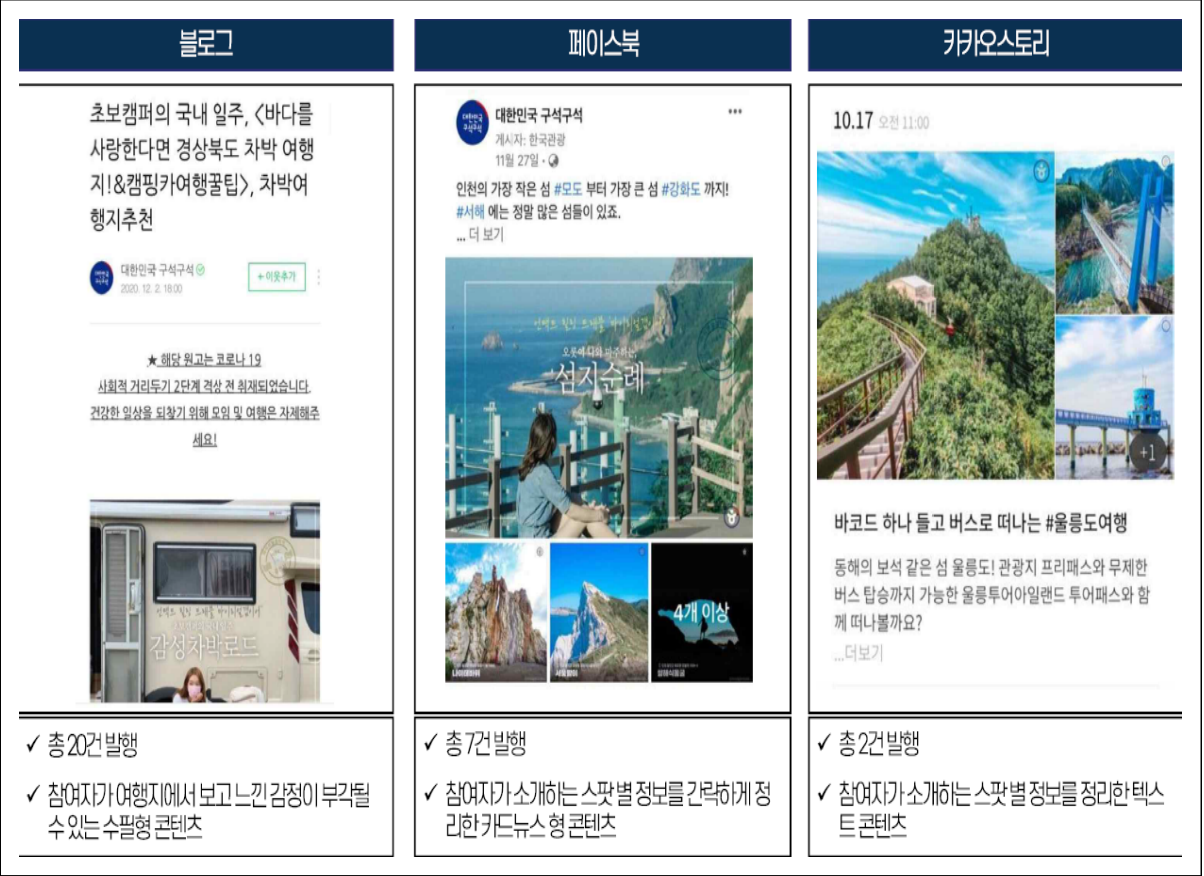

- 특히 최근 체류형 여행이 각광 받으면서 국내 지방자치단체를 중심으로 관광객 유 치 및 지역경제 활성화 목적의 한 달 살이 지원사업을 추진하고 있는 지자체 증가

- 한 달 살이 지원사업은 경남, 전남, 충북 등 수도권 밖의 지자체에서 실시하였으며, 만 18 세 이상의 지역 외 거주자를 대상으로 30 일 이내의 숙박비와 지역시설 입장 료 등의 지역관광 체험비용을 지원하는 것이 주요 형태임 
- 이 사업은 문화체육관광부의 Gap Year 프로그램과 유사하지만 지원 대상을 청년 층에 한정하지 않고 있으나 선발과정에서 체험 후기의 SNS 정기적 게재를 지원 조건에 포함시킴으로써, SNS 활용에 익숙한 청년층이 주로 선발되는 효과를 보임

- 코레일(KORAIL)은 청년층을 대상으로 일정기간 기차 무제한 이용패스인 '내일로 패스 YOUTH' 사업을 운영하고 있는데 코로나로 인한 청년들의 경제적 어려움을 덜어주기 위하여 한시적으로 연령 범위를 2021년까지 만 34세까지로 확대함

- 코레일(KORAIL)의 내일로 패스 YOUTH는 유럽의 대표적인 기차패스인 유레일 패스처럼 우리나라 기차를 통해 여행을 하는 청년들에게 교통비 부담을 덜고 국내 여행을 활성화시키는 목적이 있음

〈표 3〉 청년층 갭이어 선발자 여행주제(2020년)

\begin{tabular}{|c|c|c|c|}
\hline 구분 & 지역 & 지원 대상 & 지원 내용 \\
\hline $\begin{array}{l}\text { 남도에서 한 달 } \\
\text { 여행하기 }\end{array}$ & $\begin{array}{l}\text { 전남 고흥, 영광, } \\
\text { 해남 등 } 11 \text { 개 시군 }\end{array}$ & $\begin{array}{l}\text { 18세 이상 광주/ } \\
\text { 전남 외 거주자 }\end{array}$ & $\begin{array}{l}\text { - 숙박비(1일 } 5 \text { 만원) } \\
\text { - 지역시설 입장료 등 체험비 지원 } \\
\text { (50\% 한도) }\end{array}$ \\
\hline $\begin{array}{c}\text { 사천에서 한 달 } \\
\text { 살아보기 }\end{array}$ & 경남 사천시 & $\begin{array}{c}\text { 만 18세 이상 사천시 외 } \\
\text { 거주자 }\end{array}$ & $\begin{array}{l}\text { - 숙박비 } 5 \text { 만원(1일/1팀, } 4 \text { 인 기준) } \\
\text { - 입장료 및 체험비(실비의 } 50 \%, 1 \\
\text { 일 2만원 이내) }\end{array}$ \\
\hline $\begin{array}{l}\text { 제천에서 } \\
\text { 살아보기 }\end{array}$ & 충북 제천시 & $\begin{array}{c}\text { 제천 외 타 지역에 } \\
\text { 주소를 둔 자 } \\
\text { (개별, 팀 1인 4인 이내) }\end{array}$ & $\begin{array}{l}\text { - 숙박비(1인 1박 3만원 한도) } \\
\text { - } 1 \text { 일 체험비의 } 50 \%(1 \text { 인 1일 2만원 } \\
\text { 한도) }\end{array}$ \\
\hline $\begin{array}{c}\text { 경남별곡, 경남에서 } \\
\text { 한 달 살기 }\end{array}$ & $\begin{array}{c}\text { 통영, 김해, 하동, 산청, } \\
\text { 합천 등 } 5 \text { 개 시군 }\end{array}$ & $\begin{array}{c}\text { 경남 지역 외 거주하는 만 } \\
\text { 18세 이상 } \\
\end{array}$ & $\begin{array}{l}\text { - 숙박비 5만원 } \\
\text { - 체험, 관광지 입장료 지원 }\end{array}$ \\
\hline $\begin{array}{l}\text { 전남에서 먼저 } \\
\text { 살아보기 } \\
\text { (청년형) }\end{array}$ & 전남 영광군 & $\begin{array}{c}\text { 18세-39세 이하의 타시도 } \\
\text { 거주 청년 } \\
\text { (도내 청년은 선발인원의 } \\
30 \% \text { 이내) }\end{array}$ & $\begin{array}{l}\text { - 참가자 체류공간, 지역체험 교육 } \\
\text { 프로그램 등 지원 } \\
\text { - 생활비(식비, 교통비 등), 여행자보 } \\
\text { 험 등 자부담 }\end{array}$ \\
\hline
\end{tabular}

자료: 해당 지자체 사업안내 자료 정리

\section{나. 일본 청년관광 정책과 사례}

1) 일본 청년관광 정책 배경

- 일본은 정부 차원에서 국내외를 가리지 않고 일본 청년층의 여행을 적극 권장하고 있는데 일명 '사토리' 세대로 불리는 이들 20 30대의 일본 청년들은 일본 버블경 제 몰락기에 태어나 소극적이며 미니멀 라이프를 추구하기 때문으로 해석됨 
- 일본의 '사토리' 세대는 저성장의 여파와 고용시장 불안, 불확실한 미래로 현재의 행복을 추구한다는 점에서 $\mathrm{MZ}$ 세대와 일맥상통하지만 차이점은 '사토리' 세대는 소비에서도 소극적인 모습을 나타내는 차이점을 보임

- 미래의 일본을 책임져야 할 일본 청년층들의 이런 태도에 대한 우려와 국내관광 시장 활성화를 배경으로 일본 정부에서 추진하고 있는 대표적인 청년관광 정책사 업으로는 청년여행 ‘와카타비(若旅)' 사업과 ‘워케이션(workation)' 사업이 있음

2) '와카타비(若旅)' 사업

- 정부가 주로 주도하는 청년여행에 관한 캠페인 사업으로서 '와카타비' 는 직역하면 '젊음여행(청춘여행)'을 뜻함

- 일본 관광청은 민간, 정부, 학계로 구성된 「청년여행진흥연구회(若者旅行振興研究 ㅅ⿱二厶)」를 설치하고 청년들의 여행 의욕을 고취시키기 위하여 적극적인 캠페인을 펼 치고 있음

- 또한 캠페인과 함께 청년여행의 모범적인 사례를 선정하여 장관상을 수여하고 사 례집을 펼쳐내면서 일본 청년들이 여행에 좀 더 관심을 가지도록 노력하고 있음

- 2018년부터는 일본 국내여행 동향에서 미약하지만 일본 청년층(20-39세)의 숙박 여행 경험률이 소폭 상승, 이 현상에 대해 일본 정부는 정책효과에 긍정적 평가를 내리고 있지만 일시적 현상인지 추세전환인지의 판단은 좀 더 관찰이 요구됨

3) '워케이션(Workation)' 사업

- ‘워케이션' 사업은 일본 지자체가 먼저 시작하고 코로나19로 인해 기업의 동참이 증가하게 된 경우이며 '워케이션'은 일(Work)과 휴가(Vacation)의 합성어로 휴가 지(관광지)에서 일과 휴가를 병행하는 형태를 가리킴

- 이 사업은 일본 청년층에만 특화된 사업이 아니지만, 사업의 특성상 IT 업종에 근 무하는 청년층의 참여가 높은 특징이 있고, 정부, 기업, 근로자, 지자체의 다양한 이해관계자가 모두 수혜를 볼 수 있는 복합 효과가 있음 
- 코로나19 이후 일본기업들의 재택근무 확산과 맞물려서 워케이션에 대한 관심이 높아지면서 일본 정부는 워케이션 확대를 적극 추진하기 위해 2020년 일본 관광 전략실행추진회의(우리나라의 국가관광전략회의에 해당함)에서 워케이션을 '새로 운 여행 스타일 로 규정하고 주요 과제 중의 하나로 추진하고 있음

- 워케이션은 기업과 근로자의 상황에 따라서 다양한 형태로 진행할 수 있지만, 일본 에서는 크게 휴가형, 업무형으로 구분하고 있으며 업무형은 다시 지역과제 해결형, 합숙형, 위성 오피스형으로 나눠짐

- 현재는 위성 오피스형이 주요 형태로 추진되고 있으며 일본 와카야마현 시라하마 쵸가 대표적인 지역임

- 현재는 IT 기업 업종에 주로 한정되어 있다는 한계가 있지만, 코로나19 확산과 일본 정부의 적극적인 지원, 일/휴가 정립을 위한 근로 문화 개선 노력 등과 맞물 려 향후 점차 확대되고 관련 시장도 2025 년까지 약 5 배의 성장을 예상함

[그림 4] 일본 워케이션 유형

\section{워케이션 \\ (Work+ Vacation)}

\section{[휴가형]}

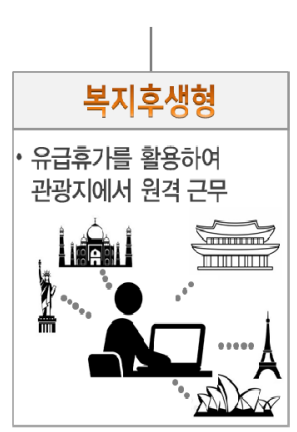

[업무형]

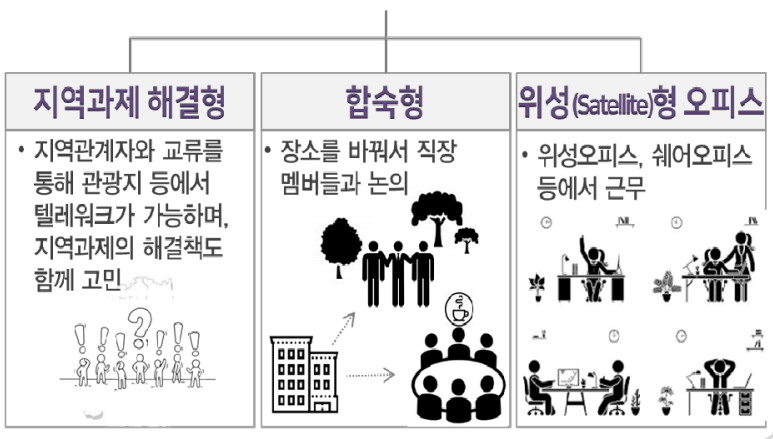

자료: https://japan-telework.or.jp/ (일본 원격근무협회) 연구자 수정 


\section{5. 청년관광 활성화 방안}

\section{가. 연구결과 종합}

- 5장에서는 연구결과를 종합하고 시사점을 정리한 후 정책방안을 제시함

〈표 4〉연구결과 종합 및 시사점 정리

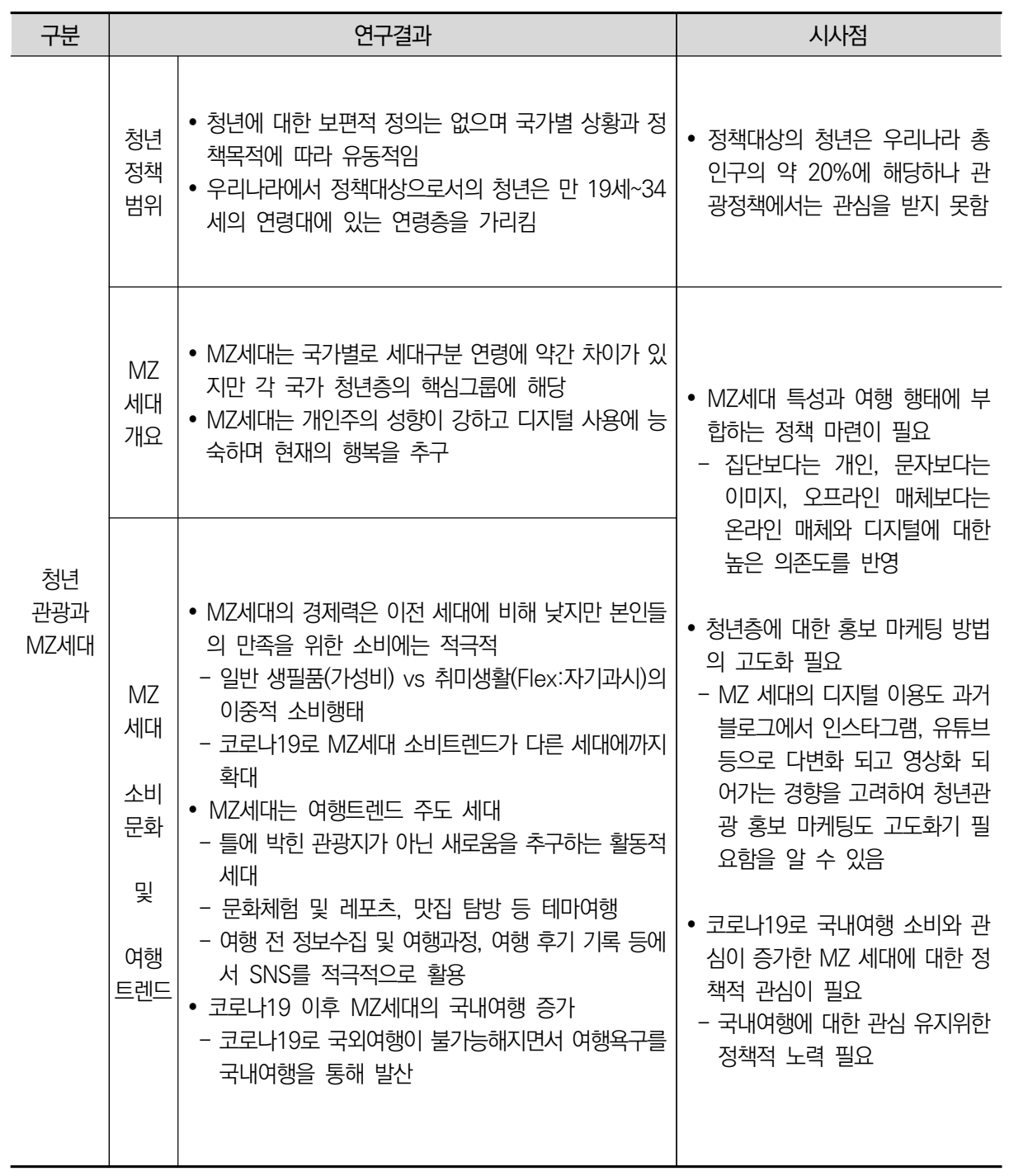


〈표 계속〉

\begin{tabular}{|c|c|c|c|}
\hline 구분 & & 연구결과 & 시사점 \\
\hline \multirow{4}{*}{$\begin{array}{c}\text { 청년층 } \\
\text { 국내관광 } \\
\text { 현황 } \\
\text { 및 } \\
\text { 특성 }\end{array}$} & $\begin{array}{l}\text { 여행 } \\
\text { 동향 }\end{array}$ & $\begin{array}{l}\text { - 청년층 국내여행 경혐율이 전체 국민 여행 경험률 } \\
\text { 보다 높음 (청년층: } 91.6 \% \text { > 전체 국민: } 86.4 \%) \\
\text { - } 1 \text { 인 평균 여행 횟수, 여행 일수, 평균 여행지 지출 } \\
\text { 도 전체 국민과 비교해 높음 } \\
\text { - 청년층이 전반적으로 여행활동이 활발하지만 세부 } \\
\text { 집단 별로 차이 } \\
\text { - 비경제활동 청년층의 경우 여행향유 격차 확대 }\end{array}$ & $\begin{array}{l}\text { - 여행에 가장 적극적인 세대 } \\
\text { - 코로나 } 19 \text { 로 관광활동이 전반적으로 } \\
\text { 위축되었지만 국내관광을 통해 관광 } \\
\text { 활동 지속 } \\
\text { - 향후 관광시장 회복과정에도 핵심적 } \\
\quad \text { 역할을 할 계층 } \\
\text { - 청년 여행 취약계층에 대한 정책적 관 } \\
\text { 심 필요 }\end{array}$ \\
\hline & $\begin{array}{l}\text { 여행 } \\
\text { 행태 }\end{array}$ & $\begin{array}{l}\text { - 여행정보 획득 경로: 온라인 매체 및 SNS 콘텐츠에 } \\
\text { 대한 선호도 높으며 단일 채널이 아닌 복수의 채널 } \\
\text { 을 활용 } \\
\text { - 디지털 매체를 통해 정보를 수집하고 다시 재생산 } \\
\text { - 여행 활동(Activities): 지역 특색을 나타내는 장소 } \\
\text { 및 체험 활동 선호 } \\
\text { - 새로운 여행지 및 다양한 여행체험 선호 } \\
\text { - 이동 수단: 여행의 자유로움 때문에 자가용을 주로 } \\
\text { 선호하나 경제적 요인에 따라서 대중교통도 이용 } \\
\text { - 코로나19로 여행안전에 대한 우려로 자가용 이용 } \\
\text { 더욱 증가 }\end{array}$ & $\begin{array}{l}\text { - 청년여행 정보제공 및 홍보 방법 정교 } \\
\text { 화 필요 } \\
\text { - 인스타그램 등 선호 SNS를 활용하 } \\
\text { 는 방법에 대한 고민 필요 } \\
\text { - 청년여행 행태를 고려한 상품 개발 } \\
\text { - 독특한 체험, 그 장소에서만 가능한 } \\
\text { 체험 관광상품 개발 } \\
\text { - 자가용 활용 증가에 대한 정책사업 } \\
\quad \text { 반영 }\end{array}$ \\
\hline & $\begin{array}{l}\text { 여행 } \\
\text { 제약 } \\
\text { 요인 }\end{array}$ & $\begin{array}{l}\text { - 국내여행 제약 주요 요인 } \\
\text { : 시간 부족, 인프라 불편, 경제적 여유 부족 } \\
\text { - 시간 부족: 직장인 청년집단에게 가장 큰 제약요 } \\
\text { 인이며 휴가사용이 어려운 직장분위기가 큰 원인 } \\
\text { - 인프라 불편: 여행 목적지 내에서의 이동, 즉 교통 } \\
\text { 인프라에 대한 불편사항이 가장 큰 제약 } \\
\text { - 경제적 여유 부족: 비경제활동 인구의 경우 부모/ } \\
\text { 친지 등으로부터 경비 지원을 통해 여행경비에 대 } \\
\text { 한 부담 }\end{array}$ & \multirow{2}{*}{$\begin{array}{l}\text { - 국내여행 제약 주요 요인 경감을 위한 } \\
\text { 정책방향 수립 } \\
\text { - 시간부족 해소: 직장인 대상 방안 마 } \\
\text { 련 필요 } \\
\text { - 교통 인프라 불편 } \\
\text { :관광지 내 이동불편 해소방안 } \\
\text { - 경제적 여유 부족: 경제적 취약 청년 } \\
\text { 계층을 위한 방안 마련 }\end{array}$} \\
\hline & $\begin{array}{l}\text { 주요 } \\
\text { 개선 } \\
\text { 희망 } \\
\text { 분야 }\end{array}$ & $\begin{array}{l}\text { - 국내여행 활성화를 위한 주요개선 희망분야 } \\
\text { : 상품개발, 서비스, 인프라 구축 등 } \\
\text { - 상품개발 및 서비스: 민간 역할 중요 } \\
\text { - 인프라 구축: 공공 역할 중요 } \\
\text { - 청년 세부집단 별로 개선희망 순위 차이 } \\
\text { - 직장인: 근로자휴가지원사업, 유연근무제 확대 시 } \\
\quad \text { 행 등 } \\
\text { - 대학생: 여행경비 지원 등 }\end{array}$ & \\
\hline
\end{tabular}




\section{나. 청년관광정책 기본방향 설정}

1) 청년관광 불편해소를 위한 인프라 개선

- 연구결과에 따르면 청년층은 여행지내에서의 이동과 숙박비 등에 대해서 제약을 느끼는 부분이 컸으며, 영유아 자녀를 동반하여 여행을 하는 기혼 청년층의 경우는 숙소의 안전과 위생 부분에 대한 큰 우려를 나타냄

- 이와 관련된 불편사항 경감을 위한 인프라 개선으로 청년들의 국내관광 편의성을 증가시켜 청년관광 활성화를 유도해야 함

2) 세부집단 수요가 반영된 청년관광 관련 제도 개선

- 연구결과에 따르면 청년층은 공통적으로 나타나는 여행 동향들도 있지만, 세부 집 단에 따라 약간씩 차별을 보이는 부분도 있으므로 청년 전체에 공통적인 정책방안 뿐 아니라 각 세부집단(sub-group)에 부합하는 제도적 개선을 마련이 요구됨

- 가령, 직장인 청년층에 대해서는 휴가 사용을 좀 더 원활하게 할 수 있고 촉진시킬 수 있는 지원방안을 마련하고 비경제 활동으로 경제적 부담이 어려운 청년층에게 는 여행경비 지원을 할 수 있는 제도적 방안이 필요함

3) 청년관광 행태가 반영된 홍보 및 콘텐츠 고도화

- $\mathrm{MZ}$ 세대 청년층의 여행 특징과 설문조사에서도 나타난 것처럼 청년층의 국내여행 은 디지털 콘텐츠와 SNS 채널에 대한 의존도가 높게 나타나는 특징을 보임

- 이처럼 인스타그램, Youtube 등의 새로운 채널이 부각하고 있으며 이미지 정보에 대한 반응을 크게 보이는 청년들의 관광행태와 취향을 반영한 홍보전략 수단을 수 립이 요구됨 


\section{다. 청년관광 정책방안}

〈표 5〉 국내관광 활성화를 위한 청년관광 정책방안(종합)

\begin{tabular}{|c|c|c|c|}
\hline 기본방향 & 정책방안 & 내용 & 추진주체 \\
\hline \multirow{3}{*}{$\begin{array}{l}\text { 청년관광 } \\
\text { 제도개선 }\end{array}$} & $\begin{array}{l}\text { 근로자휴가 } \\
\text { 지원사업 확대 }\end{array}$ & $\begin{array}{l}\text { - 근로자 휴가지원사업과 지자체 지역방문 관광객 지 } \\
\text { 원사업의 연계를 통하여 지원대상 확대 }\end{array}$ & $\begin{array}{l}\text { 문체부 } \\
\text { 지자체 }\end{array}$ \\
\hline & 워케이션 시범사업 & $\begin{array}{l}\text { - 국내 워케이션 수요조사를 통해 시범사업 추진 } \\
\text { - 근로자 휴가지원사업과도 연계검토 }\end{array}$ & $\begin{array}{l}\text { 문체부 } \\
\text { 기업 및 } \\
\text { 지자체 }\end{array}$ \\
\hline & $\begin{array}{l}\text { 청년문화누리카드 } \\
\text { 도입 }\end{array}$ & $\begin{array}{l}\text { - 청년층 경제부담 경감을 위하여 청년 문화누리카드 } \\
\text { 도입(2022년) } \\
\text { - 도입 시 경제적 취약계층 / 향후 전체 청년층으로 } \\
\text { 확대 추진 }\end{array}$ & 문체부 \\
\hline \multirow{3}{*}{$\begin{array}{l}\text { 청년관광 } \\
\text { 홍보전략 } \\
\text { 개선 }\end{array}$} & $\begin{array}{l}\text { 청년관광 인스타 } \\
\text { 100선 }\end{array}$ & $\begin{array}{l}\text { - 청년층의 SNS 선호취향을 반영한 홍보전략 추진 } \\
\text { - 해시태그를 이용한 공모방식 }\end{array}$ & 문체부 \\
\hline & $\begin{array}{c}\text { 지역관광 TV } \\
\text { 라방(라이브 방송) }\end{array}$ & $\begin{array}{l}\text { - 일방적 정보 전달이 아닌 양방향 소통 방식의 관광 } \\
\text { 홍보전략 } \\
\text { - 라이브 방송을 통한 지역관광 정보 제공 }\end{array}$ & $\begin{array}{l}\text { 문체부 } \\
\text { 지자체 }\end{array}$ \\
\hline & $\begin{array}{c}\text { 메타버스 연계 } \\
\text { 지역관광 홍보 · 마케팅 } \\
\text { 지원 }\end{array}$ & $\begin{array}{l}\text { - 가상 지역관광 콘텐츠를 체험 및 상호작용 지원 } \\
\text { - 코로나19 이후 청년층의 국내관광 관심 환기 } \\
\text { - 가상여행을 통한 지역관광 제약요인 완화 }\end{array}$ & $\begin{array}{l}\text { 문체부 } \\
\text { 지자체 }\end{array}$ \\
\hline \multirow{3}{*}{$\begin{array}{l}\text { 청년관광 } \\
\text { 인프라 개선 }\end{array}$} & $\begin{array}{l}\text { 지역관광 공유자동차 } \\
\text { 아용편의 시설지원 }\end{array}$ & $\begin{array}{l}\text { - 교통불편 지역 여행 시 청년들의 렌터카 이용 편의 } \\
\text { 증진 } \\
\text { - 청년층의 지역 내 공유차량 이용실태 조사를 통하 } \\
\quad \text { 여 사업 추진 }\end{array}$ & $\begin{array}{l}\text { 문체부 } \\
\text { 지자체 }\end{array}$ \\
\hline & $\begin{array}{l}\text { 가족친화 관광시설 } \\
\quad \text { 인증사업 }\end{array}$ & $\begin{array}{l}\text { - 안전과 위생에 대한 수요가 높은 영유아 동반 기혼 } \\
\text { 청년층을 위한 인증 } \\
\text { - 가족 친화관광사업체 인증 }\end{array}$ & 문체부 \\
\hline & $\begin{array}{l}\text { 청년 복합게스트 } \\
\text { 하우스 }\end{array}$ & $\begin{array}{l}\text { - 청년층 숙박비 부담 경감 및 장단기 체류형 숙소/ 정 } \\
\text { 보 제공 및 네트워크 장소/워케이션 참가자를 위한 } \\
\text { 공유 워크 스페이스 공간 } \\
\text { - 지자체 공모사업으로 진행 }\end{array}$ & $\begin{array}{l}\text { 문체부 } \\
\text { 지자체 }\end{array}$ \\
\hline
\end{tabular}




\section{6. 결론}

\section{가. 결론}

- 청년은 생애주기에 있어서 가장 왕성한 신체적 활동과 사회에 막 진출하기 시작한 중요한 시점이며 한 사회의 미래를 책임질 세대로서 그 사회의 향후 미래의 발전상 을 결정짓는 중요한 집단임

- 따라서 전 세계적으로 청년 문제에 많은 관심과 다양한 정책을 수립하고 있으며 이는 우리나라도 예외는 아니지만 과거 우리나라의 청년정책은 일자리 창출에 그 방점을 두었기에 청년창업에 주로 관심을 두었음

- 최근에서야 청년관광 기본계획 수립으로 청년의 삶 전반으로 청년정책의 범위가 확대되며 청년의 국내관광 활성화를 위한 수요 창출에 신경 쓰기 시작했으나 그 예산은 매우 한정적이고 유형이 마케팅과 홍보에 주로 한정되어 있음

- 본 연구에서는 이러한 문제점을 인식하고 청년관광 실태분석을 통해 국내관광 활 성화를 위한 청년관광 정책방안을 도출하고자 하였음

- 연구목적 달성을 위해 국민여행 실태조사 분석 및 설문조사, 청년층 FGI 실시, 일 본의 청년관광 사례조사 등을 통해 청년관광의 제약요인을 분석하고 청년층의 수 요를 반영한 제도개선, 청년 관광 취향에 맞는 홍보전략 수립, 청년층 불편을 경감 하는 인프라 개선의 정책방향에 따른 각각의 과제들을 제시하였음

\section{나. 정책 제언}

- 그동안 우리나라 국내관광정책에서는 청년층은 국내여행보다 국외여행을 선호한 다는 특성 때문에 청년관광정책은 우리나라 청년층의 국내여행 활성화 보다는 해 외청년층의 방한 유치에 좀 더 관심을 두어왔음

- 코로나19를 계기로 국제여행이 실질적으로 불가능해지며 국내여행에서 청년층의 영향과 활동이 매우 커졌음이 확인됨

- 코로나 전과 후를 비교한 세대별 소비지출에서도 청년층의 여행소비는 국외에서 
국내로 이동, 규모의 축소가 크지 않았으며 가장 적극적으로 국내여행에 참여하고 있음이 확인됨

- 코로나 19 의 장기화에 따라 청년층의 국내여행 활동이 당분가 지속될 것이 예상되 므로 현 시점에서 우리나라 청년들의 국내여행의 관심을 확산시키는 좋은 기회가 될 수 있으며, 청년시기의 여행경험을 통해 향후의 여행경험과 취향에도 지속적인 영향을 미칠 수 있음

- 따라서 정부는 청년시기 여행의 중요성을 고려하여 청년의 국내관광 참여 확산을 위해 정책적 관심을 지속으로 가져야 함 


\section{목차}

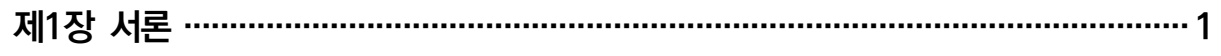

제1절 연구 배경 및 목적 3

1. 연구 배경 3

2. 연구 목적 4

제2절 연구 범위 및 방법 5

1. 연구 범위 5

2. 연구 방법 6

3. 연구 흐름도 $\quad 7$

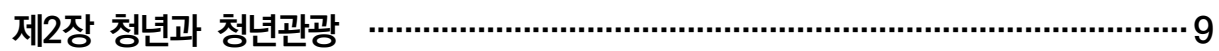

제1절 청년의 개념 및 정책범위 11

1. 청년의 개념 11

2. 우리나라 청년정책에서 청년 범위 12

제2절 청년관광의 의의 14

1. 청년관광과 개인발달 $\quad 14$

2. 청년관광과 관광산업 15

제3절 청년관광과 MZ세대 18

1. MZ세대의 특징 18

2. MZ세대의 여행트렌드 $\quad 21$

제4절 소결 $\quad 25$

1. 청년과 청년관광 25

2. 청년과 MZ세대의 여행행태 26 
제3장 청년관광 현황 및 특성 ………………………………………………….... 27

제1절 청년층 국내관광 실태분석 $\quad 29$

1. 분석 개요 29

2. 분석 결과 32

3. 소결 58

제2절 청년관광 표적집단면접(FGI) 조사 $\quad 61$

1. 조사 개요 61

2. 조사 결과 63

3. 소결 67

제3절 청년층 국내관광 특성 심층 조사 69

1. 조사 개요 69

2. 조사 결과 71

3. 소결 88

$\begin{array}{ll}\text { 제4절 종합 분석 } & 91\end{array}$

제4장 청년관광 정책현황 및 사례 ………………………………………………... 95

제1절 우리나라 청년관광 정책과 사례 97

1. 청년관광 정책의 배경과 흐름 97

2. 우리나라 청년관광 정책 사례 101

제2절 일본 청년관광 정책과 사례 109

1. 일본 청년관광 정책 배경 109

2. 일본 청년관광 정책 사례 $\quad 110$

3. 일본 워케이션(Workation) 현황 115

제3절 소결 124

1. 우리나라 청년관광정책 동향 및 사례 124

2. 일본 청년관광정책 동향 및 사례 125

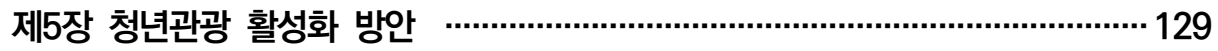

제1절 연구결과 종합 및 기본방향 설정 131

1. 연구결과 종합 131

2. 청년관광정책 기본방향 설정 133 
제2절 청년관광 정책방안

1. 청년관광 제도개선 134

2. 청년관광 홍보전략 개선 $\quad 140$

3. 청년관광 인프라 개선 145

제6장 결론 151

\section{참고문헌 / 155}

ABSTRACT / 157

부록 1. 청년층 국내관광 특성 심층 조사 조사지 양식 / 159 


\section{표 목차}

〈표 1-1〉 연구의 내용적 범위 5

〈표 2-1〉 우리나라 청년의 정의 사례 12

〈표 2-2〉 우리나라 정책대상으로서의 청년 연령 범위 13

〈표 2-3〉 미국과 한국의 세대 구분과 세대별 주요 사건 19

〈표 2-4〉 우리나라 MZ 세대의 특징과 소비문화 21

〈표 2-5〉 우리나라 세대별 여행 특징 21

〈표 3-1〉 분석 설계 30

〈표 3-2〉 분석 항목 31

〈표 3-3〉 응답자 특성 31

〈표 3-4〉여행 경험률 32

〈표 3-5〉 청년층 특성별 여행 경험률 33

〈표 3-6〉 전체 여행 횟수 34

〈표 3-7〉 청년층 특성별 국내여행 횟수 34

〈표 3-8〉1인 평균 여행 횟수 35

〈표 3-9〉 청년층 특성별 1인 평균 국내여행 횟수 36

〈표 3-10〉전체 여행 일수 37

〈표 3-11〉 청년층 특성별 국내여행 일수 37

〈표 3-12〉1인 평균 여행 일수 38

〈표 3-13〉 청년층 특성별 1인 평균 국내여행 일수 39

〈표 3-14〉 전체 여행 지출액 40

〈표 3-15〉 청년층 특성별 국내여행 지출액 40

〈표 3-16〉 1인 평균 여행 지출액 41

〈표 3-17〉 청년층 특성별 1인 평균 국내여행 지출액 42

〈표 3-18〉여행 방문지 43

〈표 3-19〉 청년층 특성별 여행 방문지(상위 3개 항목) 44

〈표 3-20〉여행 방문지 선택 이유(상위 10개 항목) 45

〈표 3-21〉 청년층 특성별 여행 방문지 선택 이유(상위 3개 항목) 45 
〈표 3-22〉 여행 정보 획득 경로

〈표 3-23〉 청년층 특성별 여행 정보 획득 경로(상위 3개 항목) 47

〈표 3-24〉 이용한 인터넷 사이트 48

〈표 3-25〉 청년층 특성별 이용한 인터넷 사이트(상위 3개 항목) 48

〈표 3-26〉 동반객 수 및 유형 49

〈표 3-27〉 청년층 특성별 동반객 수 49

〈표 3-28〉 청년층 특성별 동반객 유형(상위 3개 항목) 50

〈표 3-29〉 여행지 활동(상위 10개 항목) 51

〈표 3-30〉 청년층 특성별 여행지 활동(상위 3개 항목) 51

〈표 3-31〉 주요 이동 수단(상위 10개 항목) 53

〈표 3-32〉 청년층 특성별 주요 이동 수단(상위 3개 항목) 53

〈표 3-33〉 여행 평가 54

〈표 3-34〉 청년층 특성별 여행 평가 54

〈표 3-35〉여행사 상품 구매 여부 및 구매 시기 55

〈표 3-36〉 구매한 여행사 상품 55

〈표 3-37〉 여행 사전 예약 56

〈표 3-38〉 청년층 특성별 여행 사전 예약률 56

〈표 3-39〉 청년층 특성별 사전 예약 항목(상위 3개 항목) 57

〈표 3-40〉 청년층 국내여행 총량 비교 59

〈표 3-41〉 표적집단면접 조사 설계 62

〈표 3-42〉 표적집단면접 조사 설계 62

〈표 3-43〉 조사 설계 69

〈표 3-44〉 조사 항목 $\quad 70$

〈표 3-45〉 청년층 국내여행 특성 종합 분석 94

〈표 4-1〉 청년위원회(2013 2017) 주요 기능 97

〈표 4-2〉 우리나라 고용현황 추이(2015 2020) 98

〈표 4-3〉 청년층 갭이어 선발자 여행주제(2020년) 105

〈표 4-4〉 청년층 갭이어 선발자 여행주제(2020년) 106

〈표 4-5〉 청년층 갭이어 선발자 여행주제(2020년) 107

〈표 4-6〉 일본 청년여행 우수사례 시상내역 111

〈표 4-7〉 일본 워케이션에 대한 이해관계자 別 입장 123

〈표 5-1〉연구결과 종합 및 시사점 정리 131

〈표 5-2〉 근로자 휴가지원 사업 확대를 위한 지자체 협력방안 136 
〈표 5-3〉 근로자 휴가지원 사업 확대를 위한 지자체 협력방안 138

〈표 5-4〉 현행 문화누리카드 사업 개요 139

〈표 5-5〉 가칭 '청년 복합 게스트하우스' 사업 개요 148

〈표 5-6〉 국내관광 활성화를 위한 청년관광 정책방안(종합) 149

xxviii 국내관광 활성화를 위한 청년관광 실태 분석 및 정책방안 


\section{그림 목차}

[그림 1-1] 연구 흐름도 7

[그림 2-1] 우리나라 세대별 국내여행과 해외여행 선호도 16

[그림 2-2] MZ세대의 국내여행 특징 22

[그림 2-3] MZ세대의 "하고 싶은 일" 우선 순위(Priorities and asperations) 23

[그림 2-4] 코로나19 전후 세대 간 카드 소비 결제규모 변화 비교 24

[그림 3-1] 청년관광 현황 및 특성분석 절차 29

[그림 3-2] 최근 여행 기간

[그림 3-3] 연차 사용 71

[그림 3-4] 목적지 선택 이유_상위 10개 항목 72

[그림 3-5] 이동시간 73

[그림 3-6] 동반 유형 73

[그림 3-7] 비용 마련 방법 74

[그림 3-8] 교통수단(복수응답) 74

[그림 3-9] 자가용/렌터카 이용 이유 75

[그림 3-10] 대중교통 이용 이유 76

[그림 3-11] 이용 숙박시설_상위 10개 항목 76

[그림 3-12] 숙박시설 구매/예약처(복수응답) 77

[그림 3-13] 숙박시설 고려요인 77

[그림 3-14] 국내여행을 하는 이유 78

[그림 3-15] 국내여행 유도 콘텐츠 유형 79

[그림 3-16] 국내여행 계획 콘텐츠 유형 80

[그림 3-17] 온라인 공유 경험 $\quad 80$

[그림 3-18] 온라인 공유 방법 81

[그림 3-19] 국내여행 제약 요인 평가(긍정 응답 비율) 82

[그림 3-20] 국내여행 시간 부족 이유 82

[그림 3-21] 불편한 관광 인프라 83

[그림 3-22] 비용 부담 항목 83 
[그림 3-23] 재방문 의향

[그림 3-24] 재방문 의향 없는 이유 85

[그림 3-25] 재방문 의향 있는 이유 85

[그림 3-26] 국내여행 평가(긍정 응답 비율) 86

[그림 3-27] 개선사항 중요도(긍정 응답 비율) 86

[그림 3-28] 개선 주체 역할 중요도(공공/민간 응답 비율) 87

[그림 3-29] 추진 필요 정책 88

[그림 4-1]〈제1차 청년정책 기본계획〉 개요 99

[그림 4-2] 청년관광 공모전 (트래블리그) 홍보 포스터 101

[그림 4-3] 청년관광 공모전 (트래블리그) 진행 과정 102

[그림 4-4] 청년관광 공모전(트래블리그) 여행 가이드북 표지 103

[그림 4-5] 청년여행(트래블리그) 공모전 참가 이후 국내여행 관심도 변화 104

[그림 4-6] 청년층 갭이어 여행콘텐츠 SNS 홍보 사례(2020년) 105

[그림 4-7] 한국관광공사 대학생 유튜브 기자단 채널 영상 Capture Image 106

[그림 4-8] 일본인 국내여행 소비액 추이(2004-2019) 109

[그림 4-9] 일본 청년여행 활성화 캠페인 「와카타비(若旅)」로고 111

[그림 4-10] 일본인 국내 숙박여행 경험률 추이 (2012-2019) 113

[그림 4-11] 일본인 국내 숙박여행 경험률 비교 (2018 vs 2019) 113

[그림 4-12] 일본인 국내여행 행태 세대별 비교 (2018 vs 2019) 114

[그림 4-13] 일본 청년층 국내여행 제약요인 115

[그림 4-14] 일본 워케이션 유형 117

[그림 4-15] 일본 워케이션 시장 전망(2020 2025) 118

[그림 4-16] 일본 와카야마현(和歌山県) 시라하마초(白浜町) 위치 119

[그림 4-17] 일본 와카야마 워케이션 프로젝트 홈페이지 119

[그림 4-18] 일본 와카야마 워케이션 가이드북에 소개된 원격근무 환경 120

[그림 4-19] 일본 와카야마 워케이션 참가자들의 하이킹 모습 121

[그림 4-20] 일본 와카야마 워케이션 참가자들의 마을 돕기 모습 121

[그림 5-1] 근로자 휴가지원사업 국내여행 신규 수요창출 효과 134

[그림 5-2] 근로자 휴가지원사업 국내여행 인식개선 효과 135

[그림 5-3] 강원도 워케이션 관광상품 홍보 포스터 137

[그림 5-4] (가칭) 청년 관광 인스타 100선 공모 및 확산 과정 141

[그림 5-5] (가칭) 지역 관광 TV '라이브 방송' 지원 사업 추진 과정 143

[그림 5-6] 메타버스 연계 홍보·마케팅 사례 144 
국내관광 활성화를 위한 청년관광 실태 분석 및 정책방안

제1장

서론 



\section{제1절 연구 배경 및 목적}

\section{1. 연구 배경}

문재인 정부는 '심표가 있는 삶, 여행이 있는 삶'의 일상화를 위해 제 1 차 국가관광 전 략회의(2017.12.18.) 에서 생애주기별·계층별 관광정책을 추진할 것을 천명하였다.

이러한 정책방향은 그동안 우리 관광정책이 지나치게 양적·경제적 성과중심에 매몰되 었던 것에서 벗어나 국민, 지역주민, 방한 관광객 등 사람 중심의 질적 정책으로 방향을 전환하고자 한 것이었다. 이러한 정책기조 하에서 정부는 국민이 한 달에 한 번은 여행을 떠날 수 있고 관광객이 다시 방문 하고 싶도록 매력적인 콘텐츠와 편의를 제공하는 "심표 가 있는 삶, 사람이 있는 관광” 이라는 관광 슬로건을 제시하였다. 그리하여 생애주기별 관광지원 체계 구축을 위해서 각 주기별에 맞는 맞춤형 정책을 수립하여 수요자 지향형 정책을 추진하기로 하였다. 이러한 접근을 통해 좀 더 국민이 체감할 수 있는 정책을 집행 하고, 그 정책 과정에서 국내관광 활성화와 지역관광 자원개발을 도모하고자 했다.

본 연구의 대상이 되는 청년층은 생애주기에서 신체적으로 가장 왕성한 외부활동을 하고 여행에 대한 욕구가 강한 집단이다. 또한 청년층은 다른 연령층에 비하여 해외여행 참여와 선호도가 높은데, 반면에 국내관광에는 상대적으로 관심이 적은 계층이다. 따라 서 이러한 해외여행에 대한 쏠림 현상은 여행수지 불균형을 심화시키는 요인으로도 작 용하며 국내관광 활성화에는 부정적인 측면이 있을 수 있다. 특히 우리나라의 경우 저가 항공 도입과 글로벌 OTA 진출 등의 소비 환경 변화로 해외여행 환경이 더 용이해지면서 최근 청년들의 해외여행 선호도가 더 강해지는 경향을 나타내었다.

그러나 2020년 코로나19의 발생은 우리나라 청년층의 여행 패턴에 큰 변화를 가져오 고 있다. 코로나19로 인하여 해외여행이 불가능한 상황이 되면서 청년층의 국내여행이 활발해지고 지역관광에도 새로운 바람이 불어오고 있는 것이다. 따라서 이번 코로나19 로 인해 생긴 청년들의 국내관광에 대한 관심을 계속 유지시키고 향후로도 그 시장을 
키우는데 현 상황을 적극 활용해야 할 필요가 있다.

물론 국내관광과 해외관광은 대체재의 관계가 아니기 때문에 향후에 코로나19가 종 식되면 다시 이전처럼 청년들은 해외여행을 재개할 것이다. 그러나 해외여행이 재개가 되더라도 과거처럼 해외여행에 대한 과도한 쏠림보다는 해외여행과 국내여행의 적절한 균형을 유지시킬 수 있도록 우리나라 청년관광에 대한 정책을 수립할 필요가 있다.

\section{2. 연구 목적}

본 연구의 목적은 전술한 연구배경에 따라 국내관광 활성화를 위하여 우리나라 청년 관광의 실태를 분석하고 청년관광에 관한 정책방안을 제시하는데 있다.

구체적으로는 청년의 개념과 우리나라 청년정책에서 범위를 우선 살펴보고 본 연구에 서 청년의 의미를 규정한다. 이후 국민여행조사 원자료 분석과 표적집단면접(FGI), 청년 층 대상 설문조사 등을 통하여 우리나라 청년관광의 특성 및 행태를 분석하고, 이를 바탕 으로 우리나라 청년관광 정책현황 및 해외(일본)사례를 통해 시사점을 도출한다. 마지막 으로 연구 종합분석을 통하여 국내관광 활성화를 위한 청년정책 방안 과제를 제시한다. 


\section{제2절 연구 범위 및 방법}

\section{1. 연구 범위}

본 연구에서는 청년의 개념 및 정책대상의 범위, 청년관광의 의의, $\mathrm{MZ}$ 세대와 청년관 광, 청년관광 현황 및 특성 분석, 청년관광 국내외 정책현황 및 사례, 종합분석 및 정책 제언 등을 중심으로 연구를 수행하였다. 본 연구에서 다루어질 주요한 내용적 범위는 아래〈표 1-1〉과 같다.

〈표 1-1〉 연구의 내용적 범위

\begin{tabular}{|c|c|}
\hline 구분 & 주요 내용 \\
\hline $\begin{array}{l}\text { 청년의 개념 및 } \\
\text { 정책대상의 범위 }\end{array}$ & $\begin{array}{l}\text { - 청년의 정의와 정책대상으로서의 범위에 대한 국내외적 추세 } \\
\text { - 우리나라 정책대상에서 청년범위와 본 연구에서의 의미 }\end{array}$ \\
\hline 청년관광의 의의 & $\begin{array}{l}\text { - 청년관광과 개인발달의 관계 } \\
\text { - 관광산업 관점에서 청년관광이 갖는 의의 }\end{array}$ \\
\hline $\begin{array}{l}\mathrm{MZ} \text { 세대와 } \\
\text { 청년관광 }\end{array}$ & $\begin{array}{l}\text { - 청년세대와 } \mathrm{MZ} \text { 세대의 관계 및 특징 } \\
\text { - } \mathrm{MZ} \text { 세대의 문화소비특징과 여행특성 }\end{array}$ \\
\hline $\begin{array}{l}\text { 청년관광 현황 및 } \\
\text { 특성 분석 }\end{array}$ & $\begin{array}{l}\text { - 국민여행조사 원자료 분석을 통한 청년층 국내관광 실태 분석 } \\
\text { - 표적집단면접, 청년층 설문조사 등을 통한 청년층의 국내여행 행태 및 특성 분서- }\end{array}$ \\
\hline $\begin{array}{l}\text { 청년관광 국내외 } \\
\text { 정책현황 및 사례 }\end{array}$ & $\begin{array}{l}\text { - 우리나라 청년관광 정책현황 및 사례 } \\
\text { - 외국 청년관광 정책현황 및 사례 (일본) }\end{array}$ \\
\hline $\begin{array}{l}\text { 종합분석 및 } \\
\text { 정책제언 }\end{array}$ & $\begin{array}{l}\text { - 연구결과 종합분석을 통한 국내여행 활성화를 위한 } \\
\text { - 청년관광 정책제시 }\end{array}$ \\
\hline
\end{tabular}




\section{2. 연구 방법}

본 연구에서는 연구의 목적을 달성하기 위하여 다음과 같은 연구 방법을 사용하였다. 첫째, 청년정책 및 청년관광 관련 문헌과 2차 자료의 검토를 통하여 우리나라 청년정책 과 청년관광 정책의 배경 및 동향에 대한 흐름, 그리고 국내외 청년관광정책 사례 등을 분석하여 시사점을 도출하였다.

둘째, 정책 관계자 의견 수렴 등을 통하여 현행 청년관광 현황의 문제점과 개선방안을 도출하는 데 활용하였다. 문화체육관광부와 한국관광공사의 청년관광 정책담당자들과의 간담회를 통하여 국내 청년관광 정책 관련한 의견을 청취하였다.

셋째, 국민여행조사 원자료를 분석하여 청년층의 여행 동향 및 특징에 관한 사항들을 도출하고자 하였으며 이 자료들을 바탕으로 좀 더 구체적인 내용을 알기 위하여 청년층 1,000 명을 대상으로 설문조사를 실시하였다. 또한 계량적 설문조사를 보완하기 위하여 청년층을 대상으로 FGI 조사를 통해 정성적 분석도 병행하였다. 조사에 관한 좀 더 구체 적인 내용은 해당 장에서 기술한다.

넷째, 국외 청년관광 정책을 통한 시사점과 아이디어 발굴을 위하여 전문가 자문과 검색을 통해서 일본의 청년관광 현황과 사례조사를 시도하였다. 


\section{3. 연구 흐름도}

지금까지 설명한 연구 범위(연구 내용)와 연구 방법을 정리하여 연구 흐름도로 표시하 면 아래 [그림 1-1]과 같다.

[그림 1-1] 연구 흐름도

\begin{tabular}{|c|c|c|}
\hline 구 분 & 연구 내용 & 연구 방법연구방법 \\
\hline 서론 & $\begin{array}{l}\text { - 연구 배경 및 목적 설정 } \\
\text { • 연구 내용 및 방법 }\end{array}$ & $\begin{array}{l}\text { - 문헌연구 } \\
\text { - 관련자료 검토 }\end{array}$ \\
\hline $\begin{array}{l}\text { 청년과 } \\
\text { 청년관광 }\end{array}$ & $\begin{array}{l}\text { •• 청년의 개념 및 정책대상 범위 } \\
\text { - 청년계층과 } \mathrm{MZ} \text { 세대 } \\
\text { - MZ 세대특징 및 여행특성 }\end{array}$ & $\begin{array}{l}\text { - 관련자료 수집 } \\
\text { 및 분석 } \\
\text { - 문헌연구 }\end{array}$ \\
\hline $\begin{array}{l}\text { 청년관광 현황 및 } \\
\text { 특성 분석 }\end{array}$ & $\begin{array}{l}\text { - 우리나라 청년층 국내여행 현황 } \\
\text { - 여행 동향 및 특성 } \\
\text { - 여행 행태 } \\
\text { - 제약요인 } \\
\text { - 여행 소비 } \\
\text { - 여행정보 경로 } \\
\text { - 관심사항 등 }\end{array}$ & $\begin{array}{l}\text { - 국민여행조사 } \\
\text { 심층 분석 } \\
\text { - 표본설문조사 } \\
\text { - 표적집단면접 }\end{array}$ \\
\hline $\begin{array}{c}\text { 청년관광 } \\
\text { 국내외 정책현황 }\end{array}$ & $\begin{array}{l}\text { • 우리나라 청년관광 정책현황 검토 } \\
\text { •- 일본 청년관광 정책사례 검토 }\end{array}$ & $\begin{array}{l}\text { - 문헌조사 및 } \\
\text { 전문가 자문 }\end{array}$ \\
\hline 청년관광 활성화 방안 & $\begin{array}{l}\text {-0 국내관광 활성화를 위한 청년관광 정책방향 } \\
\text { 및 주요과제 제시 }\end{array}$ & - 연구 종합 \\
\hline
\end{tabular}



국내관광 활성화를 위한 청년관광 실태 분석 및 정책방안

제2장

청년과 청년관광 



\section{제1절 청년의 개념 및 정책범위}

\section{1. 청년의 개념}

\section{가. 청년의 정의}

청년의 사전적 의미는 '1. 신체적 - 정신적으로 한창 성장하거나 무르익은 시기에 있 는 사람, 2. 성년 남자를 뜻한다(표준국어대사전). 후자는 성별에 대한 구분을 둔 것으로 일반적으로는 남녀를 모두 포괄한 전자의 의미에 해당한다.

그러나 이는 매우 포괄적인 것으로 정책대상으로 청년을 규정할 때는 연령에 따라 청 년에 대한 범위를 설정하는 데 그 범위는 국가별로 다르다. 일반적으로 하한연령은 법정 최소 학교졸업 연령과 관련이 있으며, 상한연령은 대학졸업 연령과 관련이 있다.

청년의 범위에 대한 국제적 기준은 경제협력개발기구(OECD)와 국제연합(UN)에 의 한 것으로 이들은 만 15 세부터 만 24 세까지를 청년으로 규정하고 있으나 해외의 경우 청년들의 경제적 상황이 열악할수록 그 대상적 범위를 확대한다. 예를 들어 유럽연합 (EU) '유스개런티(Youth Guarantee: 청년보장정책)'2)의 지급연령 기준은 일반적으로 만25세까지이나 포르투갈과 같이 청년실업이 심각한 일부 국가는 만 30세까지 지급연 령을 확대하고 있으며, OECD 또한 청년 니트족3) 통계를 산출 시 만 29세까지를 청년 으로 보고 있다.

우리나라 「청년기본법」에서는 청년을 '19세 이상 34세 이하인 사람을 말한다(다만, 다른 법령과 조례에서 청년에 대한 연령을 다르게 적용하는 경우에는 그에 따를 수 있 다.)' 라고 정의하고 있으며 「청년고용촉진 특별법」에서는 “청년이란 취업을 원하는 사 람으로서 대통령령으로 정하는 나이에 해당하는 사림” 이라고 규정하고 있다. 이러한 상

2) 유스개런티(청년보장정책)는 구직활동을 하는 청년들을 지원하기 위한 목적으로 일종의 청년수당을 지급하 는 제도임

3) 니트족이란 일을 하지 않으면서, 교육이나 직업훈련도 받지 않는 청년층을 의미하는 용어임 
황을 볼 때 청년의 명확한 정의는 부재하며, 국가별 상황과 정책적 목적에 따라 그 연령 범위는 유동적인 것임을 알 수 있다.

〈표 2-1〉 우리나라 청년의 정의 사례

\begin{tabular}{c|c}
\hline 출처 & \multicolumn{1}{c}{ 정의 } \\
\hline 표준국어대사전 & 1. 신체적 · 정신적으로 한창 성장하거나 무르익은 시기에 있는 사람, 2. 성년 남자 \\
\hline 청년기본법 & $\begin{array}{l}\text { 19세 이상 34세 이하인 사람(다만, 다른 법령과 조례에서 청년에 대한 연령을 다르게 } \\
\text { 적용하는 경우에는 그에 따를 수 있음) }\end{array}$ \\
\hline 청년고용촉진특별법 & 청년이란 취업을 원하는 사람으로서 대통령령으로 정하는 나이4)에 해당하는 사람 \\
\hline
\end{tabular}

자료: 연구자 정리

\section{2. 우리나라 청년정책에서 청년 범위}

우리나라 청년정책의 기본이 되는 「청년기본법」에서는 우리나라 청년의 범위를 19 세 이상 34세까지로 규정하고 있으며 청년고용에 대한 법률인 「청년고용촉진 특별법」에서 는 청년의 하단과 상단 범위를 좀 더 넓혀서 15세 39세까지로 정하고 있다. 또한 청년 기본법 예외적 단서 조항에 명시한 것처럼 다른 법령과 조례에서 청년에 대한 연령을 다르게 적용하는 경우도 있는데 일자리 관련하여 제정된 지자체 조례의 경우가 청년의 연령 범위를 넓게 두는 경향이 있다(〈표 2-2〉 참조).

4) “대통령령으로 정하는 나이에 해당하는 사람" 이란 15 세 이상 29 세 이하인 사람을 의미함. 다만, 법 제 5 조 제1항에 따라 「공공기관의 운영에 관한 법률」에 따른 공공기관과 「지방공기업법」에 따른 지방공기업이 청 년 미취업자를 고용하는 경우에는 15세 이상 34세 이하인 사람을 지칭함 (청년고용촉진 특별법 시행령 제2조) 
〈표 2-2〉 우리나라 정책대상으로서의 청년 연령 범위

\begin{tabular}{|c|c|c|}
\hline 구분 & 내용 & 연령범위 \\
\hline 청년정책기본계획 & $\begin{array}{l}\text { - 청년의 일할 권리 보장 } \\
\text { - 청년의 주거부담 경감 } \\
\text { - 청년층 교육기회 보장 } \\
\text { - 청년층 자산형성, 건강증진, 복지 지원 등 }\end{array}$ & 19 34세 \\
\hline \multirow{3}{*}{ 청년관련법률 } & - 청년기본법 & 19 34세 \\
\hline & - 청년고용촉진 특별법 시행령 & 15 29세 \\
\hline & $\begin{array}{l}\text { - 공공기관의 운영에 관한 법률(청년고용 촉진조항) } \\
\text { - 지방공기업법(청년고용 촉진 조항) }\end{array}$ & 15 34세 \\
\hline \multirow{6}{*}{$\begin{array}{l}\text { 지방자치단체 } \\
\text { 청년관련 조례 }\end{array}$} & - 경기도 ‘청년일자리 촉진 조례’ & 15 39세 \\
\hline & - 강원도 ‘청년기본 조례’ & 18 34세 \\
\hline & - 강원도 ‘청년농어업인 육성 조례’ & 18 45세 \\
\hline & - 전남 강진군 '청년층 활성화 조례’ & 19 55세 \\
\hline & - 경북도 ‘청년창업 지원 조례’ & 15 39세 \\
\hline & - 경기도 과천시 ‘청년기본 조례’ & 19 39세 \\
\hline
\end{tabular}

자료: 청년정책기본계획 및 국가법령정보센터 자료를 바탕으로 연구자 정리

각 청년 관련 법률이나 조례에서 청년 범위를 살펴보면 공통적으로 해당되는 연령대 가 만 19세 34세에 해당되는 연령층으로 정부 정책에서는 이 연령층을 청년정책의 대 상적 범위로 설정하고 있다. 〈제1차 정년정책 기본계획〉 에서도 청년의 기준 연령을 역 시 만 19세 34세로 설정하고 있어, 본 연구에서도 청년관광 정책의 청년연령은 만 19 세 34세를 따르도록 한다. 참고로 우리나라 만 19세 34에 해당하는 인구수는 $10,510,567$ 명으로 우리나라 총 인구수 $(51,829,023)$ 의 약 $20 \%$ 를 차지한다(2020년 통 계청 인구 총조사 기준). 


\section{제2절 청년관광의 의의}

\section{1. 청년관광과 개인발달}

청년은 신체적으로 가장 왕성한 외부 활동을 하고 여행에 대한 욕구가 강한 시기로 이 시기의 여행을 통한 관광은 다른 시기에 비하여 청년에게 깊은 영향과 자극을 주게 된다. 낮선 여행지에서의 경험과 이색적인 문화체험은 청년의 자아발전과 개인의 정체성 형성에 중요한 영향을 미치기 때문이다. 즉 여행으로 대표되는 관광활동은 청년의 개인 적 발달(Personal development)에 긍정적인 영향을 통하여 개인의 정서적 발전을 자 극하게 된다.

이러한 이유로 이수현(2019)은 한국 청년들의 여행 경험에 관한 연구를 통하여 여행 이 한국 청년들의 자아를 형성하고 발전시키는 중요한 역할을 하고 있으며, 현대사회에 서 여행은 청년들의 주요한 생활양식으로 자리 잡고 있다고 주장하였다.5) 그는 한국사 회 청년들의 여행경험에 대한 문화사회학적 연구를 통해 청년들에게 여행이 주는 의미 는 단순히 관광 상품을 소비하는 것이 아니라 여행 자체가 주는 해방감과 설레임의 감정, 그리고 여행지에서의 돌발상황 등에 대한 문제 해결과 위기 극복을 통해 한 단계 더 성 장하는 것임을 강조한다.

세계관광가구(UNWTO: United Nations World Tourism Organization, 이하 UNWTO) 도 세계청년\&학생교육여행연맹(WYSE: World Youth Student \& Educational Travel Confederation)과 함께 낸 보고서에서 청년 시기의 여행이 자아에 대한 이해와 함께 다른 사회에 대한 이해도를 높이고 문화교류를 증진시키는 점을 역시 강조한 바 있다. (UNWTO \& WYSE, 2011)

이러한 여행을 통한 청년의 정서적 발전은 특히 외국여행에서 겪을 수 있는 문화교류

5) 이러한 이유로 해외에서는 고등학교 졸업 후 대학진학 또는 취업 전에 1년 정도의 기간(갭이어:Gap Year) 을 두고 장기간 여행을 통해 본인의 진로 모색과 자아 탐구에 사용한다. 
(cross-cultural experiences)를 통해 더욱 강해질 수 있는데, 청년 여행자가 나고 자 란 본인의 문화와 다른 사회 문화를 접하고 그에 대한 이해의 폭을 넓혀 한 단계 더 성장 할 수 있게 만든다(Huang, Songshan \& Chen, Ganghua, 2018).

물론 이러한 자아발달과 성숙한 인격형성은 청소년층의 교육여행(Educational Travel)에서도 강조되는 사항이다. 그러나 청소년층의 교육여행과 청년층의 여행활동이 구분되는 가장 다른 점은 여행계획의 자율성에 있다. 수학여행으로 대표되는 청소년 교 육여행의 경우 여행계획의 주체가 청소년이 아니라 학교와 교사에게 있기 때문에 여행 의 자율성이 상대적으로 떨어진다. 반면에 청년여행은 성인기에 들어선 청년이 직접 여 행지를 선택하고 일정을 계획하기 때문에 여행의 자율성이 크다. 이렇게 여행을 준비하 는 단계에서부터 청년여행은 시작되기 때문에 청년관광이 청년의 인적발전(personal development)에 미치는 영향은 다른 연령층보다 크다 할 수 있다.

\section{2. 청년관광과 관광산업}

청년관광은 개인의 정서적 발달 뿐 아니라 관광 산업 측면에서도 매우 중요한 시장을 구성하고 있어 역시 주목할 필요가 있다. UNWTO \& WYSE (2011)의 보고서에 따르면 국제관광시장에서 청년관광시장(Youth Travel Market) 은 2014년 약, 2,860억 달러 규모에서 2020년 약 4,000억 달러로 증가할 것을 예상하였다.

청년 관광시장의 경우 1 인당 소비액은 중장년층보다 작지만, 여행 기간이 길기 때문 에 평균적으로는 더 큰 소비액을 가지고 있는 장점이 있으며 경제적인 이유로 럭셔리 숙소보다는 게스트 하우스나 호스텔에 머무는 경우가 많기 때문에 지역 내에서 직접적 인 소비가 이루어지는 장점도 가지고 있다. 또한 청년여행자는 가장 적극적이고 모험을 추구하는 여행자(Adventurer)이며 어느 정도의 위험은 감수하는 여행자(Risk-taker)들 로서 코로나19가 어느 정도 안정이 되면 가장 먼저 여행을 시작할 계층으로 예상되고 있다. 실제로 WYSE 에서 2020년에 실시한 여행업 동향 조사에 따르면 청년층을 대상 으로 하는 여행업에서는 여행 재개에 대해서 좀 더 긍정적인 기대를 가지고 있는 것으로 나타나기도 했다(WYSE Press release, 2020). 
다만 이러한 청년관광의 관광산업적 가치가 주로 주목하고 있는 섹터는 국제관광시장 이며 국내관광(domestic tourism)에서는 청년관광이 아직까지는 주목받는 분야가 아 니다. 이러한 이유는 앞서 기술한 것처럼 국제관광에서 청년관광 시장의 성장 잠재력이 높은 이유도 있겠지만, 청년들의 국제여행 선호도가 높은 것에도 기인한다.

청년들이 국내여행보다 해외여행을 선호하는 현상은 우리나라에서도 확인할 수 있는 데, 조아라김형종(2019)의 연구에 따르면 우리나라 2-30대가 다른 세대에 비해서 해외 여행 선호도가 높은 것으로 나타났다([그림 2-3] 참조).

[그림 2-1] 우리나라 세대별 국내여행과 해외여행 선호도

\begin{tabular}{|c|c|c|c|c|c|c|}
\hline 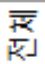 & & 33.1 & \multicolumn{4}{|c|}{66.9} \\
\hline \multirow{5}{*}{ 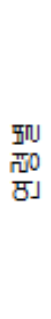 } & 60 대 & 37.1 & \multicolumn{4}{|c|}{62.9} \\
\hline & 50대 & 38.7 & \multicolumn{4}{|c|}{61.3} \\
\hline & 40 대 & 33.2 & \multicolumn{4}{|c|}{66.8} \\
\hline & 30대 & 29.8 & \multicolumn{4}{|c|}{70.2} \\
\hline & 20 대 & 27.0 & \multicolumn{4}{|c|}{73.0} \\
\hline \multirow{4}{*}{$\begin{array}{l}\text { कूर } \\
\text { ₹ }\end{array}$} & 여성 & 33.1 & \multicolumn{4}{|c|}{66.9} \\
\hline & 남성 & 33.1 & \multicolumn{4}{|c|}{66.9} \\
\hline & & $20 \%$ & $40 \%$ & $60 \%$ & $80 \%$ & $100 \%$ \\
\hline & \multicolumn{6}{|c|}{ 국내여핵 해외여핵 } \\
\hline
\end{tabular}

자료: 조아라 김형종(2019), [국민의 해외여행 동향분석],p.135

청년들은 해외여행을 선호하는 이유로 해외여행을 경험하는 것 자체가 의미 있고 흥 미 있는 일이라고 응답하였는데, 이는 해외여행을 국내여행을 대체하는 여행이라기보다 는 국내여행과는 전혀 다른 성격의 여행으로 인식하고 있음을 시사한다. 또한 비용적인 측면에서도 국내여행과 비교하면, 해외여행이 가성비가 좋고 콘텐츠에서 즐길 거리가 다 양한 것도 국내여행보다 해외여행을 선호하는 것으로 들고 있다(조아라김형종, 2019).

특히 최근에는 저가항공과 공유 숙박, 글로벌 OTA, 여행 전문 App 개발 등의 원인으 로 해외여행의 비용이 많이 저렴해지고 용이해지면서 우리나라 젊은 층의 해외여행에 대한 선호도가 심화되고 있다. 이러한 현상은 최근 호주 관광청에서 실시한 조사에서도 
비슷한 결과를 보였는데, 호주의 청년들도 역시 호주의 국내관광을 선호하지 않는 이유 가 해외여행에 비하여 (호주) 국내관광이 가격적인 장점이 별로 없고, (이국적인) 해외여 행지에 비하여 호주의 관광 콘텐츠가 특별히 매력적(attractive)이지 않다는 반응을 보 였다.6) 이러한 배경으로 청년관광이 관광산업에서 차지하는 중요성은 국제관광 측면에 서만 주로 그동안 주목받아 왔던 것이다.

그러나 코로나 19 의 발생으로 인하여 국제관광이 자유롭지 못 하게 되면서 청년층의 관광 목적지가 국내로 이동하는 현상이 발생하면서 국내관광 시장 섹터에서도 청년관광 의 산업적 가치를 새롭게 발견할 필요성이 대두되고 있는데 이 부분에 대해서는 다음 절에서 $\mathrm{MZ}$ 세대의 특성과 함께 다루도록 한다.

6) "Australia tourism: Why don't young Australians want to see their own country?" https://www.traveller.com.au/australia-tourism-why-dont-young-australians-want-to-seetheir-own-country-h1qqj9 


\section{제3절 청년관광과 $\mathrm{MZ}$ 세대}

\section{MZ세대의 특징}

\section{가. 세대구분과 세대연구}

세대는 세(世)와 대(代)의 합성어로 세는 사람의 한평생을 뜻하고, 대는 대신하여 잇는 다는 뜻이다. 이러한 세대는 본래 전통사회에서 가계의 체계를 구성하는 개념으로 선대 와 뒤를 잇는 후대를 의미하였고 생물학적 연령으로는 약 30 년을 한 단위로 한다(두산백 과 \& 한국민족문화대백과). 그러나 현대사회에 오면서 세대의 의미는 연령적 구분보다 공통의 체험을 기반으로 하며 공통의 의식이나 풍속을 전개하는 공통적 집단의 의미가 더욱 강해졌고, 보통 특정한 사건이나 사회적 변동을 겪으면서 이러한 세대적 구분이 이루어지게 된다.

한편 이러한 사건이나 사회적 변동은 세계적 규모(Global Scale)인 것도 있지만, 국 지적(Local) 것도 있어 세대 구분은 국가별로 조금씩 차이가 있을 수 있다. 예를 들어 '밀레니얼 세대’ 라는 용어는 20세기에서 21세기로의 세기 전환을 바탕으로 한 세계적 규모의 것으로서 통용되지만, 실업과 경제적 어려운 현실에 처한 'N포 세대' 라는 용어 는 한국의 해당 세대에 대한 좀 더 특수한 현실을 반영하는 용어라고 할 수 있다.

또한 세대적 구분에 있어 베이비붐 세대, X세대 등 세대적 용어는 동일하여도 각 세대 에 대한 시간적 분류에도 조금씩 차이가 있는데 이는 각 세대를 구분 짓는 큰 사건 등의 발생 시기적 차이가 있기 때문이다. 미국의 베이비붐 세대는 제 2 차 세계대전 종전이 그 시작점이 되지만, 한국의 경우 6.25 종전 이후가 시작점이 되는 것이 그러한 차이를 보 여주는 예(例)가 될 것이다. 
〈표 2-3〉미국과 한국의 세대 구분과 세대별 주요 사건

\begin{tabular}{|c|c|c|c|c|}
\hline 구분 & 베이비붐 세대 & X세대 & 밀레니얼세대 & Z세대 \\
\hline \multirow[b]{2}{*}{ 미국 } & $\begin{array}{c}\text { 1946 1964년 } \\
\text { 출생 }\end{array}$ & $\begin{array}{l}\text { 1965 1978년 } \\
\text { 출생 }\end{array}$ & $\begin{array}{l}\text { 1979 1995년 } \\
\text { 출생 }\end{array}$ & $\begin{array}{l}\text { 1996 2010년 } \\
\text { 출생 }\end{array}$ \\
\hline & $\begin{array}{c}\text { 2차대전 종전 } \\
\text { 베트남전쟁 } \\
\text { 히피문화 } \\
\text { 인권운동 } \\
\text { 달 착륙 }\end{array}$ & $\begin{array}{c}\text { 베를린 장벽 } \\
\text { 붕괴/냉전종식 } \\
\text { AIDS(후천성면역결핍) } \\
\text { 걸프전 } \\
\text { MTV POP문화 }\end{array}$ & $\begin{array}{c}9.11 \text { 테러 } \\
\text { 소셜 미디어(SNS) } \\
\text { 비디오 게임 } \\
\text { Y2K }\end{array}$ & $\begin{array}{c}\text { 경기침체 } \\
\text { 지구온난화 } \\
\text { 흑인대통령 당선 } \\
\text { Youtube }\end{array}$ \\
\hline \multirow[b]{2}{*}{ 한국 } & $\begin{array}{l}\text { 1955 1969년 } \\
\text { 출생 }\end{array}$ & $\begin{array}{l}\text { 1970 1983년 } \\
\text { 출생 }\end{array}$ & $\begin{array}{l}\text { 1984 1996년 } \\
\text { 출생 }\end{array}$ & $\begin{array}{l}\text { 1997 2010년 } \\
\text { 출생 }\end{array}$ \\
\hline & $\begin{array}{l}6.25 \text { 동란 휴전 } \\
\text { 원조경제 } \\
\text { 산업화/도시화 } \\
4.19 \text { 혁명 } \\
5.16 \text { 군사쿠데타 }\end{array}$ & $\begin{array}{c}\text { 경제성장 } \\
\text { 88서울올림픽 } \\
\text { 해외여행 자유화 } \\
\text { 대통령 직선제 } \\
\text { PC 통신 }\end{array}$ & $\begin{array}{l}\text { 평화적 정권교체 } \\
\text { IMF 경제위기 } \\
\text { 인터넷 } \\
2002 \text { 월드컵 } \\
\text { 디지털 1세대 }\end{array}$ & $\begin{array}{l}\text { 저성장 고착 } \\
\text { 세월호 } \\
\text { 한류 } \\
\text { 공유경제 } \\
\text { 멀티태스킹 }\end{array}$ \\
\hline
\end{tabular}

자료: 제프 프롬\& 앤지 리드(2018). 〈Z세대가 온다〉, p. 23. 연구자 내용 수정.

그렇다면 세대구분을 통한 세대연구의 의의는 무엇인가? 그것은 이러한 세대연구를 통하여 특정 세대의 사회적 이슈와 행동, 특성에 대한 이해를 하는 데 도움이 될 수 있기 때문이다. 물론 개개인에 대한 연구가 아니라 집단에 대한 연구이기 때문에 지나친 일반 화(over-generalization)의 위험을 가질 수 있지만, 많은 인구를 대상으로 하는 정책수 립과 집행에서 있어서 세대에 대한 이해는 필수적인 것은 부정할 수 없다. 또한 정책연 구 뿐 아니라 정치학, 사회학, 인구학적 측면에서도 각 세대가 가지는 특성과 이해관계 에 따른 세대 간 갈등 및 문제 해결 등에 대해서도 관심을 가져왔다(전상진, 2004; 허석 재, 2015). 특히 현대사회에서 빠르게 변화하는 트렌드 연구와 관련하여 이러한 세대에 관한 연구는 특정 세대의 문화생활이나 소비행태 등을 파악함으로써 유용하게 사용될 수 있는 측면이 있다. 그러므로 본 연구에서도 우리나라 청년층에 해당하는 MZ세대(밀 레니얼 세대 $+\mathrm{Z}$ 세대)의 특징에 대해서 알아볼 필요가 있다.

\section{나. MZ세대의 소비문화}

$\mathrm{MZ}$ 세대는 어린 시절부터 디지털 환경에 노출됐기 때문에 이전 세대에 비해 신기술 에 거부감이 없으며 집단보다는 개인, 일과 휴식의 균형을 중요하게 여기는 세대로 평가 받고 있다. 또한 개인의 취향을 존중하고 여러 채널을 통해 정보를 습득하되, 텍스트 기 
반의 오프라인 정보보다는 이미지 기반의 온라인 정보를 더욱 활용하는 특징이 있다. 그러나 이들은 금융위기 이후 경제 양극화와 저성장, 자동화 등으로 인한 양질의 일자리 가 감소하면서 생애 소득이 이전 세대보다 감소할 것으로 추정되어 이른바 "부모 세대보 다 가난한 첫 세대“라고 지칭되고 있기 때문에 이전 세대들보다 경제적 구매력은 낮은 것으로 평가받고 있다.

실제로 우리나라 국민연금 가입자의 연령별 소득 자료를 활용하여 연령-소득 프로파 일을 추정한 심혜정(2019)의 연구에 따르면 연령별 구간 생애 평균임금은 1978년생 이 후부터는 직전 세대의 소득 수준에서 정체하거나 하락하는 것으로 나타난 바 있다. 또한 $\mathrm{MZ}$ 세대와 이전 세대 간의 소득 격차는 코로나 19 로 인하여 기업들이 신규고용을 꺼려 청년층의 실업문제로 더욱 커질 가능성이 높다. 이러한 이유로 $\mathrm{MZ}$ 세대는 고성장 시대 에 경제적 성장과 소득이 동행하던 이전 세대와는 다르게 저성장과 고용침체의 일상화 로 경제적 소득의 감소를 우려해야 하는 첫 세대로서 평균 소비성향은 감소하고 있다(홍 춘욱·박종훈, 2019).

그러나 평균 소비성향은 감소하지만 $\mathrm{MZ}$ 세대는 한편으로는 본인의 만족을 위한 소비 에는 적극적인 모습을 보이는 이중적인 형태를 보인다. 이러한 양상의 기저에는 어차피 경기침체 장기화와 부동산 가격 폭등으로 주택과 같은 대규모 자금이 들어가는 자산구 입은 어려워지자 $\mathrm{MZ}$ 세대는 불확실한 미래보다는 현재의 행복에 충실하려는 욕망이 반 영된 것으로 보인다.

일반적인 생필품에는 가성비를 중요시여기지만 그들의 취미생활이나 문화생활에는 과감히 투자하는 Flex(자기과시) 소비를 추구하기도 한다. 실제로 하나은행 하나금융연 구소(2021a)에서 분석한 국내 세대별 2020년 카드 소비 분석 결과에 따르면 2020년 전체 온라인 명품 결제규모의 약 $55 \%$ 를 20,30 대가 차지하는 것으로 나타나 MZ세대의 자기표현과 과시욕이 소비성향에 반영된 것으로 드러났다.

그리고 $\mathrm{MZ}$ 세대는 디지털 기기에 익숙한 세대로서 온라인 소비에도 친숙한데, 코로 나19 이후로 이른바 비대면 경제활동이 증가하면서 이러한 $\mathrm{MZ}$ 세대의 소비 행태는 다 른 세대에게도 점차 확대되고 있기도 하다(우리금융연구소, 2021b). 
〈표 2-4〉 우리나라 MZ 세대의 특징과 소비문화

\begin{tabular}{c|c}
\hline 구분 & \multicolumn{1}{|c}{ 특징 } \\
\hline 경제력 & ・ 저성장과 경기침체의 장기화로 이전 세대에 비해 경제력은 낮음 \\
\hline 소비성향 & $\begin{array}{l}\text { ・ 평균 소비성향은 다른 세대에 비해 낮지만 본인들의 만족을 위한 분야는 과감한 소비 } \\
\text { '가성비' 와 'Flex' 의 야누스적 소비 }\end{array}$ \\
\hline 소비채널 & $\begin{array}{l}\text { - 온라인 쇼핑에 익숙하며 라방(Live 방송을 통한 쇼핑)이나 공동 구매 등의 새로운 소비 } \\
\text { 채널에도 거리낌이 없음 }\end{array}$ \\
\hline
\end{tabular}

자료: 연구자 정리

\section{MZ세대의 여행트렌드}

$\mathrm{MZ}$ 세대는 문화 및 여가분야 소비를 통해 자신의 취향을 확인하고 재미와 만족을 추 구하는데 이러한 소비 행태는 여행 활동(Travel Activity)에도 반영되고 있다. 그들은 판에 박힌 패키지 상품보다는 자신의 취향에 따라 여행을 계획하고 동적 Activity 와 맛집 탐방 등 다양한 체험을 원한다.

한국관광공사(2021)에서 빅 데이터 분석을 통해 MZ세대의 선호관광지를 분석 결과 $\mathrm{MZ}$ 세대의 특성은 문화관광지를 선호하고 동시에 새로운 여행지를 발굴하는 적극적인 여행자로 나타났다(〈표 2-5〉 및 [그림 2-2] 참조).

〈표 2-5〉 우리나라 세대별 여행 특징

\begin{tabular}{|c|c|c|c|c|}
\hline 구분 & 10대 & 20-30대(MZ세대) & $\mathrm{X}$ 세대\&베이비붐 세대 & 시니어 세대 \\
\hline $\begin{array}{l}\text { 활동력 및 } \\
\text { 활동반경 }\end{array}$ & $\begin{array}{l}\text { - 여행의 기회가 적고 } \\
\text { 거주지 인근에서 여 } \\
\text { 행활동을 즐기는 소 } \\
\text { 극적 여행자 } \\
\text { - 체험 학습형 여행자 }\end{array}$ & $\begin{array}{l}\text { - 일상을 벗어난 새로 } \\
\text { 움을 추구하는 활동 } \\
\text { 적 여행세대 } \\
\text { - 여행의 트렌드 리더 }\end{array}$ & $\begin{array}{l}\text { - 적극적 여행향유자 } \\
\text { 이지만 내부중심 여 } \\
\text { 행가 } \\
\text { - 잡식성 여행자 }\end{array}$ & $\begin{array}{l}\text { - 소극적 일상 여행자 } \\
\text { - 자연 친화형 일상 } \\
\text { 여행자 }\end{array}$ \\
\hline 코로나19 영향 & $\begin{array}{l}\text { - 코로나19에 의해 더 } \\
\text { 욱 위축된 여행세대 }\end{array}$ & $\begin{array}{l}\text { - 코로나19 이후 국 } \\
\text { 내여행 증가 }\end{array}$ & $\begin{array}{c}\text { - 코로나190|후 사회 } \\
\text { 관계 활동 감소로 } \\
\text { 여행활동도 감소 }\end{array}$ & $\begin{array}{l}\text { - 건강염려 등으로 생 } \\
\text { 활관광 등 추구 }\end{array}$ \\
\hline $\begin{array}{l}\text { 선호 관광지 } \\
\quad \text { 유형 }\end{array}$ & $\begin{array}{l}\text { - 체험형.학습형 여행 } \\
\text { 목적지 선호 }\end{array}$ & $\begin{array}{c}\text { - 문화체험 및 레포츠 } \\
\text { / 새로운 여행지 }\end{array}$ & - 힐링/웰니스 & $\begin{array}{l}\text { - 산, 바닷가의 자연 } \\
\text { 관광지 }\end{array}$ \\
\hline
\end{tabular}

자료: 한국관광공사(2021), [빅데이터에 남겨진 세대별 여행기록], 연구자 수정 
[그림 2-2] MZ세대의 국내여행 특징

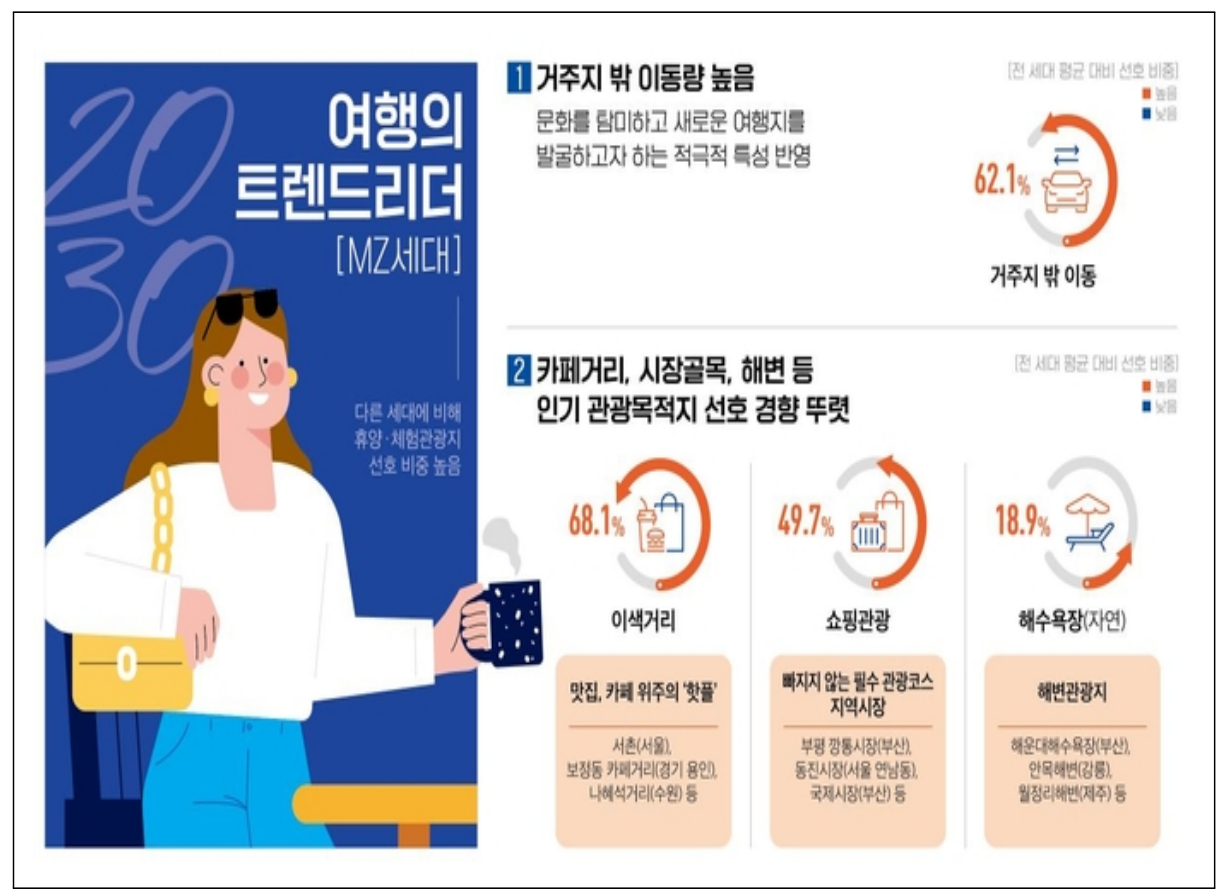

자료: 한국관광공사(2021), [빅데이터에 남겨진 세대별 여행기록]

특히 MZ세대는 여행을 계획할 때 디지털 매체를 적극 활용하며, 디지털 환경에 익숙 하기 때문에 한 가지 매체 뿐 아니라 여러 채널(네이버, 유튜브, 인스타그램, 구글 등)을 동시 이용하고, 또한 여행 과정 및 여행 기록을 본인도 SNS 에 기록하여 지인들과 공유 하여 여행의 시작과 끝이 SNS를 통해 이루어진다. 이들 중에는 블로그와 Youtube를 통하여 전문적인 여행 작가나 여행 youtuber로 활동하는 경우도 있는데, 이들은 여행 인플루언서로 영향력을 미친다. 이원희.박주영.조아라(2019)는 MZ 세대를 여행에 적극 적이며 향후 여행 트렌드를 주도할 세대(trend setter)로 평가하고 이 세대의 특징을 '(1) 나를 위한 아낌없는 여행 (2) 영상에 의한 여행 (SNS를 통한 정보 습득) (3) 영상을 위한 여행(SNS 기록)'으로 규정하였다.

$\mathrm{MZ}$ 세대는 또한 집단에서의 인정이나 직장에서의 승진, 높은 급여보다 개인의 행복과 자유 등을 선호하는 특성을 가지고 있다. 이들의 이러한 성향은 여행욕구에도 반영되는 데 딜로이트 컨설팅에서 조사한 Survey를 보면 세계여행을 가장 하고 싶은 일 1순위로 답하고 있다([그림 2-3] 참조). 
[그림 2-3] MZ세대의 “하고 싶은 일" 우선 순위(Priorities and asperations)

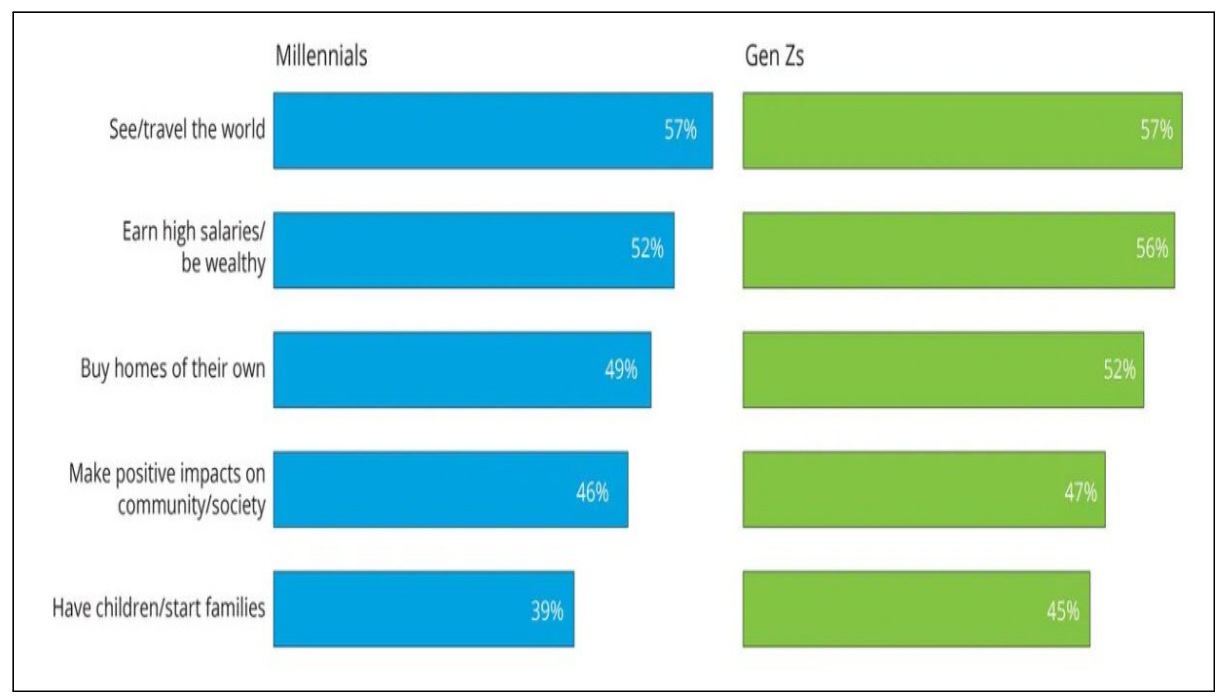

자료: Deloitte Development LLC(2019), [Deloitte Global Millennial Survey], p.14

그러나 코로나19는 해외여행에 대한 수요와 시장 전체의 전반적인 위축으로 나타났 다. 그러나 $\mathrm{MZ}$ 세대의 경우 해외여행이 어려워지자 그들의 여행욕구를 국내여행을 통해 서 부분적으로 해소하고 있다.

앞서 한국관광공사 빅데이터에서도 나타난 것처럼 코로나19 발생 이후 2020년 MZ 세대는 생활권 밖 이동량이 전 세대 평균보다 $62.1 \%$ 많은 것으로 나타났다.

이렇게 MZ세대의 코로나19 이후 국내여행 확대에 대한 데이터는 신용카드 소비액에 의해서도 다시 한 번 확인할 수 있다. 하나은행 하나금융경영연구소에서 2019년 1월부 터 2020년 12월까지 총 2년간의 하나카드(개인 신용카드 및 체크카드 기준) 온라인 결 제 데이터를 분석하여 코로나19 이전과 이후의 소비 행태를 비교분석한 결과, 여행, 숙 박 분야가 코로나19 이후 전 연령층에서 순위가 크게 하락하였지만 20대에서는 큰 차이 가 없는 것으로 나타났다.

구체적으로 [그림 2-4]를 보면 다른 세대들의 경우 여행, 숙박 분야에서 카드 결제 규모 순위의 하락이 크지만, 20대의 경우 여행, 숙박 분야에서의 카드 결제 규모 변화가 5 위->6위로 한 계단만 하락한 것을 알 수 있다. 이는 MZ세대의 핵심층인 20대의 경우 여행, 숙박의 소비가 감소하기는 하였지만, 많은 부분이 국외여행에서 국내여행으로 흡 수되었음을 시사한다. 이러한 코로나 19 이후 $\mathrm{MZ}$ 세대인 청년층의 국내여행 참여 증가 
에 대한 것은 본 연구의 FGI 에서도 다시 한 번 확인할 수 있었는데, 그 부분은 3장에서 다시 기술한다.

[그림 2-4] 코로나19 전후 세대 간 카드 소비 결제규모 변화 비교

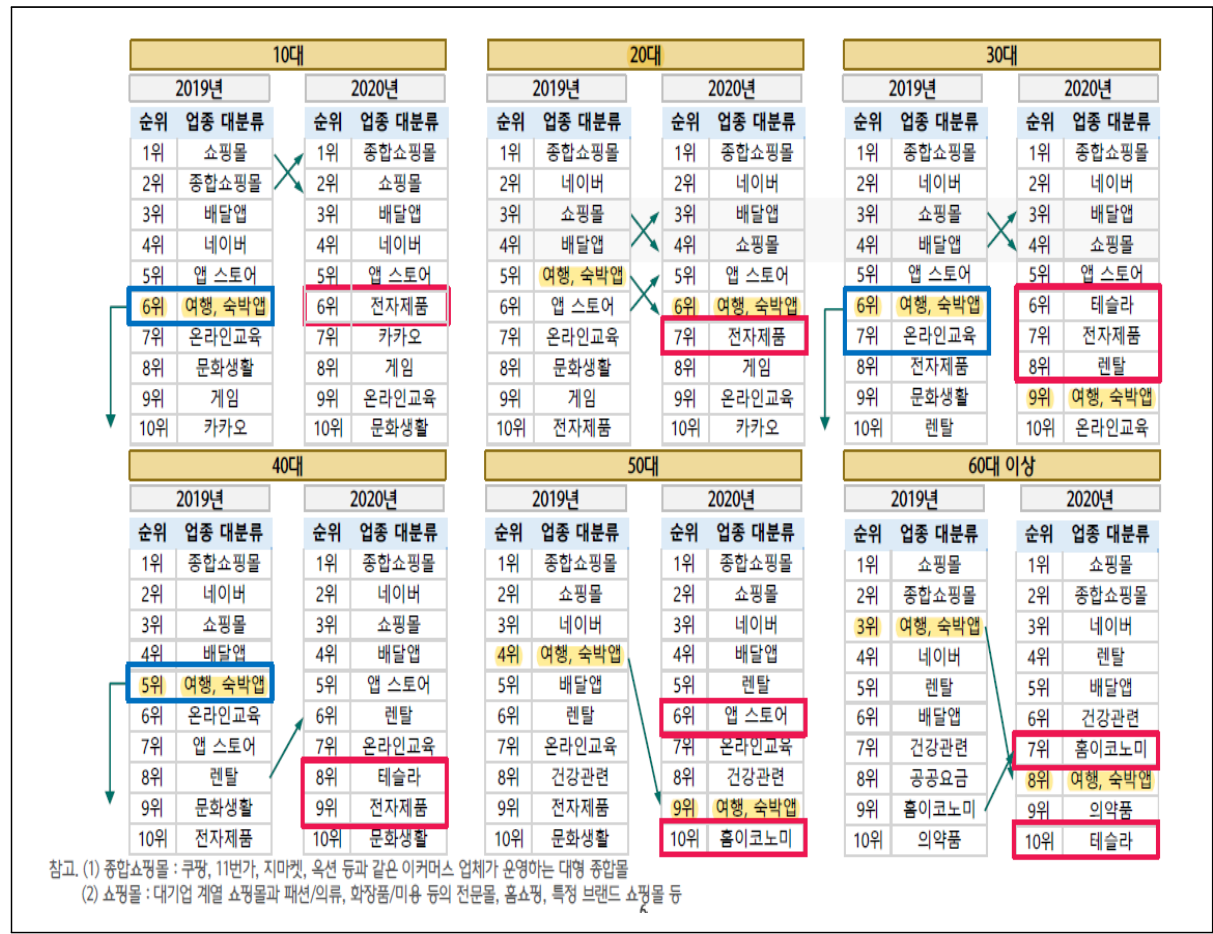

자료: 하나은행 하나금융경영연구소(2021), 세대별 온라인 소비행태 변화와 시사점 


\section{제4절 소결}

\section{1. 청년과 청년관광}

청년의 정의에 대한 보편적 정의는 없으며 보통 연령으로 구분을 한다. 이러한 이유로 청년의 범위는 국가별 상황과 정책 대상에 따라서 유동적이다. 보통 경제적 상황이 어려 울수록 청년의 범위를 넓게 잡으며 고용정책에 해당할수록 그러한 경향이 더욱 강하다. 우리나라의 경우도 마찬가지인데 청년정책의 근간이 되는 「청년기본법과 청년종합정책 인 〈제1차 청년정책 기본계획〉 에서는 그 연령을 만 19세 34세로 규정하고 있으며 본 연구에서도 같은 연령대를 청년의 범위로 본다. 이 연령대는 2020년 기준으로 우리나라 총 인구수의 약 $20 \%$ 를 차지하는 비중이다.

청년에게 있어 청년관광이 가지는 의의는 두 가지 측면에서 고찰할 수 있는데 첫째는 청년의 개인적 발달(personal development)이며 둘째는, 관광산업적인 측면에서의 청 년관광의 잠재력이다.

우선 관광활동인 여행을 통하여 청년은 자기 주도적인 여행계획과 여행지에서의 경 험, 문제의 해결을 통해 자아형성과 인격성숙의 긍정적인 영향을 받을 수 있다. 즉 여행 은 청년에게 개인적 발달을 이룰 수 있는 하나의 기제(機制)로 작동할 수 있는 것이다.

또한 관광산업적인 측면에서도 빠르게 성장하는 청년관광시장의 잠재성을 감안할 필 요가 있는데 그동안 이러한 관광 산업적 측면에서의 청년관광에 대한 평가는 주로 국제 관광시장 섹터에 쏠렸던 경향이 있다. 이러한 이유는 일반적인 관광정책이 인바우드 정 책에 쏠렸던 것과 함께 청년들의 해외여행에 대한 선호 등이 그 배경으로 추정할 수 있 다. 그러나 코로나 19 의 발생으로 인하여 최근 청년층의 국내여행에 대한 관심과 활동이 증가하여 국내관광 차원에서의 청년관광에 대해 주목해야 할 필요성이 증가하였다. 


\section{2. 청년과 $\mathrm{MZ}$ 세대의 여행행태}

청년계층의 핵심집단인 MZ세대의 특성은 여행행태에 많은 영향을 미친다.

이들은 여행패턴에서도 MZ세대의 취향이 반영된 체험관광지 및 독특한 장소를 선호 한다. 단순한 자연관광지 보다는 문화체험이나 동적 레포츠를 선호하며 스토리가 결합되 어 있는 장소적 매력이 있는 곳을 좋아하고 새로운 여행지를 적극적으로 발굴한다.

또한 여행의 소 과정에서 SNS 와 온라인 콘텐츠의 활용이 크게 관여하고 있다. SNS 을 통해 정보를 습득하고, 자신들의 여행기록을 다시 SNS 에 기록하면서 여행 트렌드를 주도하는 트렌드리더로 활동하고 있다.

$\mathrm{MZ}$ 세대는 다른 세대에 비해 국내여행보다 국제여행에 대한 선호도가 높다. 이들은 경험하지 못한 세계에 대해 매력을 느끼며, 새로운 것을 체험하는 것을 두려워하지 않기 때문이다. 또한 최근 저가항공과 공유숙박, OTA 등 국제여행을 쉽고 저렴하게 해줄 수 있는 여행 환경도 $\mathrm{MZ}$ 세대의 국제여행에 대한 선호도를 강화시키는 요소들이다.

그러나 코로나19의 발생으로 국제여행이 실제적으로 불가능해지면서 MZ세대의 그들 의 여행욕구를 국내여행을 통해서 발산시키고 있다. 세대별 여행소비 규모에서도 $\mathrm{MZ}$ 세대는 다른 세대에 비해 그 감소폭이 가장 적어 여행지를 국외에서 국내로 이동시켰음 을 시사한다. 
국내관광 활성화를 위한 청년관광 실태 분석 및 정책방안

제3장

청년관광 현황 및 특성 



\section{제1절 청년층 국내관광 실태분석}

\section{1. 분석 개요}

본 장에서는 청년층의 국내관광 현황과 특성을 분석함으로써 청년관광 및 국내관광 활성화 방안 수립의 근거가 되는 기초자료를 제시하고자 하였다. 이를 위해 일차적으로 국민여행조사 원자료를 분석하여 청년층의 국내관광 실태를 검토하였으며, 두 번째 단계 는 청년관광 표적집단면접 조사로서 국민여행조사 원자료 분석 결과를 바탕으로 청년층 의 국내관광 인식 및 행태를 다각적으로 살펴보았다. 마지막 단계는 상기 검토 과정을 통해 드러난 청년층의 국내관광 특성을 바탕으로 청년층 국내관광 특성을 심층 조사하 기 위한 조사계획을 수립하고 구조화된 설문지를 통해 온라인 조사를 실시하였다.

\section{[그림 3-1] 청년관광 현황 및 특성분석 절차}

\begin{tabular}{|c|c|}
\hline 구분 & 주요 내용 \\
\hline $\begin{array}{l}\text { 국민여행조사 } \\
\text { 원자료 분석 }\end{array}$ & - 국내 청년층(만 19세-34세)의 전반적인 국내관광 현황 및 행태 분석 \\
\hline $\begin{array}{l}\text { 청년층 } \\
\text { 표적집단면접 조사 } \\
\text { (미혼자,기혼자/ } \\
\text { 경제활동 여부) }\end{array}$ & $\begin{array}{l}\text { - 국민여행조사 분석 결과를 바탕으로 청년층 대상 } \mathrm{FGI} \text { 실시 } \\
\text { - 결혼 및 자녀 유무, 경제활동 여부(학생, 직장인 등)에 따라 세부 그룹을 } \\
\text { 편성하여 면접조사 실시 } \\
\text { - 청년층의 국내관광 인식 및 행태, 세분 집단별 특성을 다각도로 검토 }\end{array}$ \\
\hline $\begin{array}{l}\text { 청년층 국내관광 } \\
\text { 특성 심층조사 }\end{array}$ & $\begin{array}{l}\text { - 청년층(만 } 19 \text { 세-34세) 대상 국내관광 특성 심층조사 실시 } \\
\text { - 온라인 조사, 표본 수 } 1,000 \text { 명 } \\
\text { - 청년층의 관광 행태, 국내관광 제약 요인, 청년관광 지원정책 인식 및 수 } \\
\text { 요 등 조사 }\end{array}$ \\
\hline $\begin{array}{l}\text { 종합 분석 및 } \\
\text { 시사점 도출 }\end{array}$ & $\begin{array}{l}\text { - 청년층의 국내관광 행태, 제약요인, 평가 및 개선사항 등 청년관광 활성 } \\
\text { 화 방안 도출을 위한 청년층 관광특성(세분집단)별 종합분석 }\end{array}$ \\
\hline
\end{tabular}




\section{가. 분석 목적}

본 절에서는 국내관광 시장 활성화를 위하여 청년의 국내관광 실태를 파악하고, 청년 관광 정책발굴을 위한 기초자료 제공하기 위한 목적으로 국민여행조사 원자료 분석을 수행하였다. 국민여행조사는 국민의 국내여행 총량, 여행 행태, 평가 등에 대한 폭넓은 정보를 담고 있을 뿐만 아니라, 매년 연속적으로 조사가 수행되어 시간의 흐름에 따른 변화를 관찰하는데 적합한 장점이 있다. 따라서 본 절에서는 국민여행조사 원자료를 활 용하는데 있어서 청년층의 국내관광 실태를 파악하는 것은 물론 코로나19 전후의 결과 비교를 통해 코로나19로 인한 청년층의 국내관광 행태 변화를 함께 살펴보고자 하였다.

\section{나. 분석 설계}

본 절에서는 국민여행조사 원자료 중 청년층(만19-34세) 데이터를 추가분석 함으로 써 청년층의 여행 총량 및 행태 파악하고 전체 국민과 비교되는 특징을 도출하고자 하였 으며, 분석의 대상은 2019년부터 2020년까지 최근 2년간 국민여행조사에 응답한 청년 층(만19-34세) 국내여행 데이터로 2019년 10,974개(월평균 약 915개), 2020년 11,646 개(월평균 약 971개)를 대상으로 하였다.

〈표 3-1〉 분석 설계

\begin{tabular}{c|l}
\hline 구분 & \multicolumn{1}{c}{ 내용 } \\
\hline \multirow{2}{*}{ 분석 대상 } & $\begin{array}{l}\text { ・ 2019년 2020년 국민여행조사 청년층(만19-34세) 응답 데이터 } \\
\text { • 국내여행 데이터 }\end{array}$ \\
\hline \multirow{2}{*}{ 분석 데이터 } & $\begin{array}{l}\text { ・ 2019년 10,974개 } \\
\text { • 2020년 11,646개 }\end{array}$ \\
\hline
\end{tabular}

\section{다. 분석 내용}

본 절의 분석 항목은 청년층의 여행 총량 부문과 여행 행태 부문으로 구성된다(표 3-2> 참조). 본 절에서 분석한 청년층의 여행 총량 및 여행 행태 분석 결과는 2019년, 2020년 국민여행조사의 전체 국민 여행 특성과 비교함으로써 청년층 고유의 특성을 도 출하는데 활용하고자 하였다.

또한, 국민여행조사 원자료 분석 시 청년층을 성별, 연령, 직업, 주5일근무제, 혼인상 
태, 자녀 여부, 가구소득 등에 따라 세분화함으로써 청년층 내 집단 간 특성 차이를 확인 하고자 하였다.

아울러 2020년 1월 국내에서 첫 번째 코로나19 확진자가 발생한 이후 우리 국민의 국내관광 행태가 크게 변화된 것으로 전망되어 왔는데, 본 절에서는 2019년과 2020년 국민여행조사 원자료 분석 결과를 비교함으로써 코로나19로 인한 청년층의 국내관광 행 태변화를 함께 고찰하여 향후 청년층의 국내관광 회복을 위한 의미있는 시사점을 도출 하고자 노력하였다.

〈표 3-2〉 분석 항목

\begin{tabular}{|c|c|c|c|}
\hline \multicolumn{2}{|r|}{ 구분 } & \multicolumn{2}{|c|}{ 내용 } \\
\hline & 여행 총량 & $\begin{array}{l}\text { - 여행 경험률 } \\
\text { - 여행 횟수 }\end{array}$ & $\begin{array}{l}\text { - 여행 일수 } \\
\text { - 여행 지출액 }\end{array}$ \\
\hline $\begin{array}{l}\text { 분석 } \\
\text { 항목 }\end{array}$ & 여행 행태 & $\begin{array}{l}\text { - 여행 방문지 } \\
\text { - 여행 방문지 선택 이유 } \\
\text { - 여행 정보 획득 경로 } \\
\text { - 동반객 수 및 유형 } \\
\text { - 여행지 활동 }\end{array}$ & $\begin{array}{l}\text { - 주요 이동 수단 } \\
\text { - 주요 숙박 시설 } \\
\text { - 행동 의도 } \\
\text { - 여행사 상품 구매 } \\
\text { - 여행 사전 예약 }\end{array}$ \\
\hline
\end{tabular}

본 절에서 수행하는 분석 대상 자료의 응답자 특성은 아래 〈표 3-3〉과 같이 나타난다. 데이터의 분포는 원 조사인 국민여행조사의 표본설계에 따라 나타난 결과이며, 2020년 기준 전체 국민여행조사 원자료 50,710 건 중 11,646 건으로 약 $23 \%$ 를 차지하고 있다.

〈표 3-3〉 응답자 특성

[단위: 명]

\begin{tabular}{|c|c|c|c|c|c|}
\hline \multirow{2}{*}{\multicolumn{2}{|c|}{ 구분 }} & \multicolumn{2}{|c|}{ 2019년 } & \multicolumn{2}{|c|}{ 2020년 } \\
\hline & & 전체 & 청년층 & 전체 & 청년층 \\
\hline \multicolumn{2}{|c|}{ 전체 } & 48,269 & 10,974 & 50,710 & 11,646 \\
\hline \multirow{2}{*}{ 성별 } & 남성 & 24,036 & 5,938 & 25,251 & 6,259 \\
\hline & 여성 & 24,233 & 5,036 & 25,459 & 5,387 \\
\hline \multirow{6}{*}{ 연령대 } & 10대 & 2,976 & 653 & 3,442 & 628 \\
\hline & 20대 & 7,077 & 7,077 & 7,491 & 7,491 \\
\hline & 30대 & 7,466 & 3,244 & 8,122 & 3,527 \\
\hline & 40대 & 8,897 & - & 9,651 & - \\
\hline & 50대 & 9,341 & - & 9,603 & - \\
\hline & 60대 이상 & 6,542 & - & 12,401 & - \\
\hline
\end{tabular}




\section{2. 분석 결과}

\section{가. 여행 총량}

\section{1) 여행 경험률}

2020년 기준 청년층의 국내여행 경험률은 91.6\%로 전체 국민의 여행 경험률 $86.4 \%$ 대비 높은 것으로 나타났다. 2019년에는 청년층(91.2\%)이 전체 국민(92.4\%) 대비 다소 낮은 국내여행 경험률을 보였으나, 2020년에는 코로나 19 확산의 영향으로 전체 국민의 여행 경험률은 감소한 반면, 청년층의 국내여행 경험률은 소폭 상승한 것으로 나타났다.

특히, 전체 국민의 관광여행 경험률은 약 $10 \%$ 감소한 반면, 청년층의 관광여행 경험 률은 전년과 유사한 수준을 유지하여 코로나19 확산에도 청년층은 지속적으로 관광여행 을 경험하였음을 알 수 있다.

〈표 3-4〉여행 경험률

[단위: \%]

\begin{tabular}{c|c|c|c|c}
\hline \multirow{2}{*}{ 구분 } & \multicolumn{2}{|c|}{ 2019년 } & \multicolumn{2}{c}{ 2020년 } \\
\cline { 2 - 5 } & 전체 & 청년층 & 전체 & 청년층 \\
\hline 국내여행 & 92.4 & 91.2 & 86.4 & 91.6 \\
\hline 관광여행 & 85.0 & 83.6 & 75.5 & 82.4 \\
\hline 기타여행 & 69.5 & 63.6 & 53.7 & 53.8 \\
\hline
\end{tabular}

청년층 내 세분집단별 국내여행 경험률을 살펴보면 2019년에는 전체 집단에서 고르 게 높은 국내여행 경험률을 나타내고 있으나 2020년에는 집단별 국내여행 경험률의 차 이가 두드러지게 나타난다. 경제활동 유형별로 살펴보면 전업주부(86.5\%) 및 무직 (75.9\%)의 국내여행 경험률이 전년대비 큰 폭으로 감소하였으며, 가구형태별 특성을 살 펴보면 기혼(89.4\%) 가구, 자녀동반(86.1\%) 가구의 국내여행 경험률 감소폭이 높은 것 으로 나타났다. 
〈표 3-5〉 청년층 특성별 여행 경험률

[단위: \%]

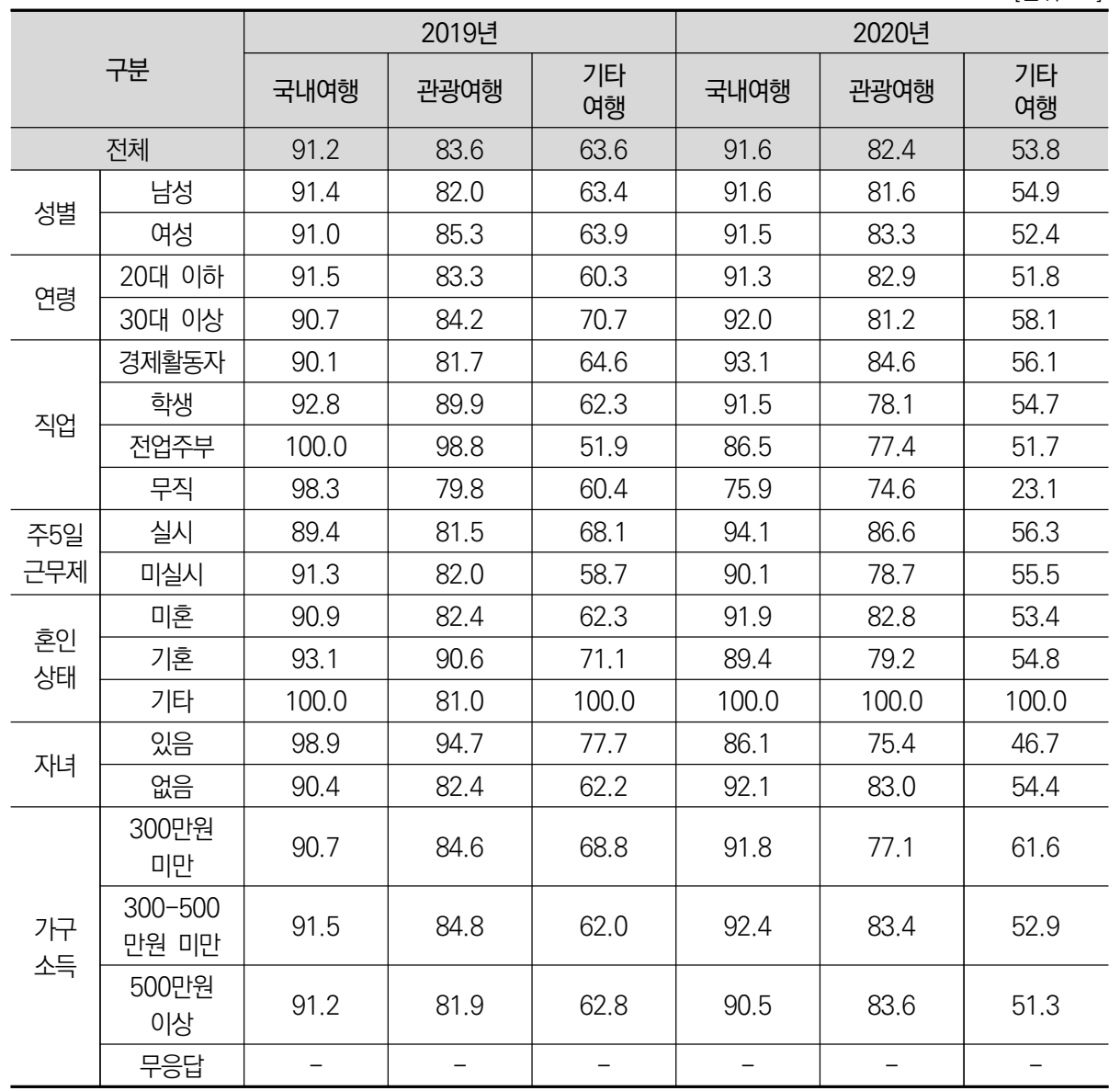

\section{2) 여행 횟수}

2020년 기준 청년층의 국내여행 횟수는 6,509만 2,000천 회로 전체 국내여행 횟수 의 2억 2,519만 9,000회의 28.9\%를 차지하는 것으로 나타났다. 2020년에는 코로나19 의 영향으로 전체 국민과 청년층 모두에서 국내여행 횟수가 크게 감소하였으나, 전체 국민의 국내여행 횟수는 2019년 대비 $34.7 \%$ 감소한 반면, 청년층은 $28.1 \%$ 감소하여 감소폭은 상대적으로 작은 것으로 나타났다. 그러나 전체 국민과 청년층 모두에서 당일 여행 대비 숙박여행의 감소율이 더 높은 것으로 나타나 코로나 19 의 확산이 국민의 숙박 여행 감소에 큰 영향을 끼쳤음을 알 수 있다. 특히, 전업주부, 기혼 가구, 자녀 동반 가구 에서 국내여행 횟수가 상대적으로 크게 줄어든 것으로 확인되었다. 
〈표 3-6〉 전체 여행 횟수

[단위: 천 회]

\begin{tabular}{|c|c|c|c|c|c|}
\hline \multirow{2}{*}{\multicolumn{2}{|c|}{ 구분 }} & \multicolumn{2}{|c|}{ 2019년 } & \multicolumn{2}{|c|}{ 2020년 } \\
\hline & & \multirow{2}{*}{$\begin{array}{c}\text { 전체 } \\
344,750\end{array}$} & \multirow{2}{*}{$\begin{array}{c}\text { 청년층 } \\
90,558\end{array}$} & \multirow{2}{*}{$\begin{array}{c}\text { 전체 } \\
225,199\end{array}$} & \multirow{2}{*}{$\begin{array}{l}\text { 청년층 } \\
65,092\end{array}$} \\
\hline \multirow{3}{*}{$\begin{array}{l}\text { 국내 } \\
\text { 여행 }\end{array}$} & 전체 & & & & \\
\hline & 숙박여행 & 162,376 & 43,354 & 88,450 & 25,891 \\
\hline & 당일여행 & 182,374 & 47,204 & 136,749 & 39,200 \\
\hline \multirow{3}{*}{$\begin{array}{l}\text { 관광 } \\
\text { 여행 }\end{array}$} & 전체 & 263,257 & 72,098 & 170,642 & 52,101 \\
\hline & 숙박여행 & 129,603 & 35,490 & 68,834 & 21,562 \\
\hline & 당일여행 & 133,654 & 36,608 & 101,808 & 30,539 \\
\hline \multirow{3}{*}{$\begin{array}{l}\text { 기타 } \\
\text { 여행 }\end{array}$} & 전체 & 81,492 & 18,460 & 54,556 & 12,991 \\
\hline & 숙박여행 & 32,772 & 7,864 & 19,616 & 4,329 \\
\hline & 당일여행 & 48,720 & 10,596 & 34,940 & 8,661 \\
\hline
\end{tabular}

〈표 3-7〉 청년층 특성별 국내여행 횟수

[단위: 천 회]

\begin{tabular}{|c|c|c|c|c|c|c|c|}
\hline & \multirow{2}{*}{ 구분 } & \multicolumn{3}{|c|}{ 2019년 } & \multicolumn{3}{|c|}{ 2020년 } \\
\hline & & 전체 & 숙박여행 & 당일여행 & 전체 & 숙박여행 & 당일여행 \\
\hline \multicolumn{2}{|r|}{ 전체 } & 90,558 & 43,354 & 47,204 & 65,092 & 25,891 & 39,200 \\
\hline \multirow{2}{*}{ 성별 } & 남성 & 46,247 & 21,788 & 24,459 & 34,453 & 13,803 & 20,650 \\
\hline & 여성 & 44,311 & 21,566 & 22,745 & 30,638 & 12,088 & 18,550 \\
\hline \multirow{2}{*}{ 연령 } & 20대 이하 & 61,455 & 28,782 & 32,673 & 43,829 & 17,338 & 26,491 \\
\hline & 30대 이상 & 29,103 & 14,572 & 14,531 & 21,262 & 8,553 & 12,709 \\
\hline \multirow{4}{*}{ 직업 } & 경제활동자 & 65,134 & 31,215 & 33,919 & 48,361 & 19,439 & 28,922 \\
\hline & 학생 & 18,377 & 8,432 & 9,946 & 12,979 & 4,906 & 8,073 \\
\hline & 전업주부 & 3,466 & 2,032 & 1,434 & 1,490 & 609 & 881 \\
\hline & 무직 & 3,581 & 1,675 & 1,906 & 2,261 & 937 & 1,324 \\
\hline \multirow{2}{*}{$\begin{array}{l}\text { 주5일 } \\
\text { 근무제 }\end{array}$} & 실시 & 45,492 & 21,364 & 24,128 & 36,983 & 14,640 & 22,343 \\
\hline & 미실시 & 19,642 & 9,851 & 9,791 & 11,378 & 4,799 & 6,579 \\
\hline \multirow{3}{*}{$\begin{array}{l}\text { 혼인 } \\
\text { 상태 }\end{array}$} & 미혼 & 76,257 & 36,232 & 40,024 & 56,263 & 22,160 & 34,102 \\
\hline & 기혼 & 14,066 & 6,943 & 7,123 & 8,649 & 3,582 & 5,067 \\
\hline & 기타 & 235 & 179 & 56 & 180 & 149 & 31 \\
\hline \multirow{2}{*}{ 자녀 } & 있음 & 8,948 & 4,389 & 4,559 & 4,521 & 1,710 & 2,811 \\
\hline & 없음 & 81,610 & 38,965 & 42,645 & 60,570 & 24,181 & 36,390 \\
\hline \multirow{4}{*}{$\begin{array}{l}\text { 가구 } \\
\text { 소득 }\end{array}$} & $\begin{array}{c}\text { 300만원 } \\
\text { 미만 }\end{array}$ & 17,588 & 8,639 & 8,950 & 11,667 & 4,970 & 6,697 \\
\hline & $\begin{array}{l}300-500 \\
\text { 만원 미만 }\end{array}$ & 36,829 & 16,831 & 19,997 & 26,685 & 10,028 & 16,657 \\
\hline & $\begin{array}{c}\text { 500만원 } \\
\text { 이상 }\end{array}$ & 36,141 & 17,884 & 18,257 & 26,740 & 10,893 & 15,847 \\
\hline & 무응답 & - & - & - & - & - & - \\
\hline
\end{tabular}




\section{3) 1 인 평균 여행 횟수}

2020년 기준 청년층 1 인당 평균 국내여행 횟수는 6.06회로 전체 국민의 4.95회 대비 1.11 회 많은 것으로 나타났다. 2020년에는 코로나19의 영향으로 전반적으로 여행 횟수 가 감소한 것으로 나타났으나, 전체 국민은 2019년의 7.61회 대비 2.66회 감소한 반면, 청년층은 2019년의 8.23회 대비 2.17회 감소하여 상대적으로 소폭 감소하는데 그쳤다. 특히, 국내여행 횟수는 감소하였음에도 청년층이 전체 국민 대비 평균 여행 횟수가 높다 는 경향성은 변하지 않은 것으로 나타났다.

〈표 3-8〉1인 평균 여행 횟수

\begin{tabular}{c|c|c|c|c|c}
\hline \multirow{2}{*}{\multicolumn{2}{|c|}{ 구분 }} & \multicolumn{2}{|c|}{ 2019년 } & \multicolumn{2}{c}{ 2020년 } \\
\cline { 3 - 6 } \multicolumn{2}{c|}{} & 전체 & 청년층 & 전체 & 청년층 \\
\hline \multirow{3}{*}{$\begin{array}{c}\text { 국내 } \\
\text { 여행 }\end{array}$} & 전체 & 7.61 & 8.23 & 4.95 & 6.06 \\
\cline { 2 - 6 } & 숙박여행 & 3.59 & 3.94 & 1.94 & 2.41 \\
\cline { 2 - 6 } & 당일여행 & 4.03 & 4.29 & 3.01 & 3.65 \\
\hline \multirow{3}{*}{$\begin{array}{c}\text { 관광 } \\
\text { 여행 }\end{array}$} & 전체 & 5.81 & 6.55 & 3.75 & 4.85 \\
\cline { 2 - 6 } & 숙박여행 & 2.86 & 3.23 & 1.51 & 2.01 \\
\cline { 2 - 6 } & 당일여행 & 2.95 & 3.33 & 2.24 & 2.84 \\
\hline \multirow{3}{*}{$\begin{array}{c}\text { 기타 } \\
\text { 여행 }\end{array}$} & 전체 & 1.80 & 1.68 & 1.20 & 1.21 \\
\cline { 2 - 6 } & 숙박여행 & 0.72 & 0.71 & 0.43 & 0.40 \\
\cline { 2 - 6 } & 당일여행 & 1.08 & 0.96 & 0.77 & 0.81 \\
\hline
\end{tabular}

청년층 내 세분집단별 1인당 평균 국내여행 횟수를 살펴보면 2019년에는 여성(8.73 회), 30대 이상(8.48회), 전업주부(9.58회), 주5일 근무제 실시 직장인(8.86회), 기혼 가 구(8.91회), 자녀동반 가구(9.18회) 등의 1 인당 평균 국내여행 횟수가 높았으나, 2020 년에는 2019년과 달리 전업주부의 평균 국내여행 횟수가 4.96회 감소하여 감소폭이 가 장 높았고, 자녀가 있는 경우에도 평균 국내여행 횟수가 3.61회 감소하여 여행 횟수가 크게 감소한 것으로 나타났다. 또한 무직자는 2019년과 2020년 공통적으로 전체 평균 대비 국내여행 횟수가 적은 경향성을 나타내고 있으나 2020년에는 1 인당 평균 국내여 행 횟수가 3.34회 감소하여 전체 평균과의 격차가 2019년 0.66일에서 1.83 일로 크게 증가한 것으로 나타났다. 
〈표 3-9〉 청년층 특성별 1인 평균 국내여행 횟수

[단위: 회]

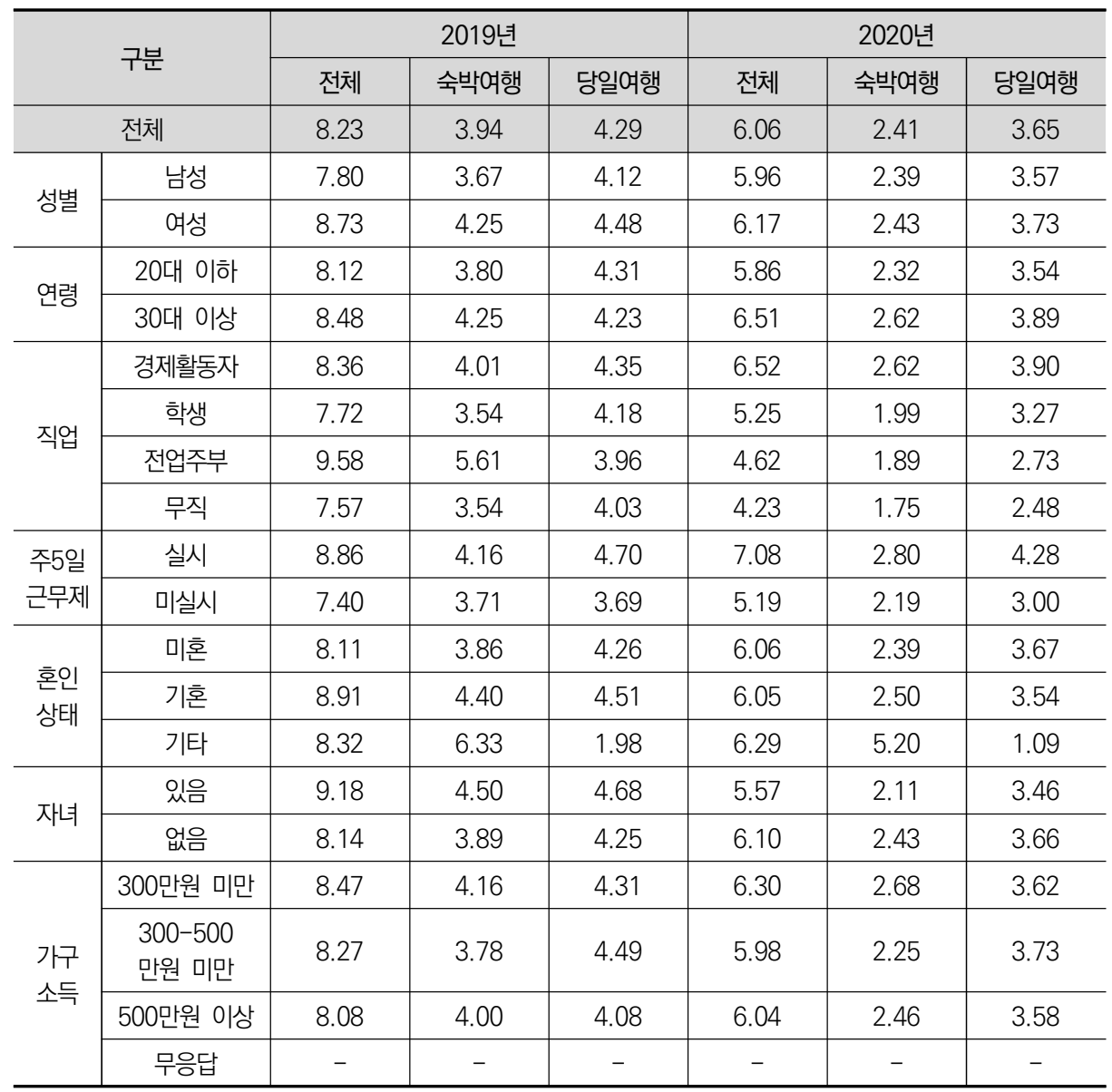

\section{4) 여행 일수}

2020년 기준 청년층의 여행 일수는 1 억 1 만 9,000일로 전체 국민의 3억 4,787만 6,000 일 가운데 $28.8 \%$ 를 차지하는 것으로 나타났다. 2020년 국내여행 일수는 코로나 19 확산의 영향으로 전반적으로 감소한 모습이나, 전체 국민 감소율 $40.6 \%$ 대비 청년층 의 감소율 $35.7 \%$ 은 상대적으로 낮은 것으로 확인되었다. 여행 유형별 살펴보면 전체 국 민(47.7\%)과 청년층(43.9\%) 모두에서 당일여행 대비 숙박여행의 감소율이 높은 것으로 확인되었으나, 청년층의 당일여행 감소율(17.0\%)은 다른 여행 유형 대비 상대적으로 낮 은 수준을 보였다. 한편, 자녀가 있는 청년층의 경우, 전년 대비 $80 \%$ 이상 감소하였다. 
〈표 3-10〉 전체 여행 일수

[단위: 천 일, \%]

\begin{tabular}{|c|c|c|c|c|c|}
\hline \multirow{2}{*}{\multicolumn{2}{|c|}{ 구분 }} & \multicolumn{2}{|c|}{ 2019년 } & \multicolumn{2}{|c|}{ 2020년 } \\
\hline & & 전체 & 청년층 & 전체 & 청년층 \\
\hline \multirow{3}{*}{$\begin{array}{l}\text { 국내 } \\
\text { 여행 }\end{array}$} & 전체 & 585,710 & 155,884 & 347,876 & 100,199 \\
\hline & 숙박여행 & 403,336 & 108,680 & 211,127 & 60,999 \\
\hline & 당일여행 & 182,374 & 47,204 & 136,749 & 39,200 \\
\hline \multirow{3}{*}{$\begin{array}{l}\text { 관광 } \\
\text { 여행 }\end{array}$} & 전체 & 453,051 & 124,387 & 264,445 & 80,531 \\
\hline & 숙박여행 & 319,397 & 87,779 & 162,636 & 49,992 \\
\hline & 당일여행 & 133,654 & 36,608 & 101,808 & 30,539 \\
\hline \multirow{3}{*}{$\begin{array}{l}\text { 기타 } \\
\text { 여행 }\end{array}$} & 전체 & 132,659 & 31,497 & 83,431 & 19,669 \\
\hline & 숙박여행 & 83,939 & 20,901 & 48,491 & 11,007 \\
\hline & 당일여행 & 48,720 & 10,596 & 34,940 & 8,661 \\
\hline
\end{tabular}

〈표 3-11〉 청년층 특성별 국내여행 일수

[단위: 천 일]

\begin{tabular}{|c|c|c|c|c|c|c|c|}
\hline & \multirow{2}{*}{ 구분 } & \multicolumn{3}{|c|}{ 2019년 } & \multicolumn{3}{|c|}{ 2020년 } \\
\hline & & 전체 & 숙박여행 & 당일여행 & 전체 & 숙박여행 & 당일여행 \\
\hline \multicolumn{2}{|r|}{ 전체 } & 155,884 & 108,680 & 47,204 & 100,199 & 60,999 & 39,200 \\
\hline \multirow{2}{*}{ 성별 } & 남성 & 78,847 & 54,388 & 24,459 & 52,910 & 32,260 & 20,650 \\
\hline & 여성 & 77,037 & 54,292 & 22,745 & 47,289 & 28,739 & 18,550 \\
\hline \multirow{2}{*}{ 연령 } & 20대 이하 & 104,827 & 72,154 & 32,673 & 67,041 & 40,549 & 26,491 \\
\hline & 30대 이상 & 51,057 & 36,526 & 14,531 & 33,158 & 20,449 & 12,709 \\
\hline \multirow{4}{*}{ 직업 } & 경제활동자 & 112,321 & 78,402 & 33,919 & 74,555 & 45,633 & 28,922 \\
\hline & 학생 & 30,639 & 20,693 & 9,946 & 19,767 & 11,694 & 8,073 \\
\hline & 전업주부 & 6,899 & 5,465 & 1,434 & 2,347 & 1,465 & 881 \\
\hline & 무직 & 6,025 & 4,120 & 1,906 & 3,530 & 2,206 & 1,324 \\
\hline \multirow{2}{*}{$\begin{array}{l}\text { 주5일 } \\
\text { 근무제 }\end{array}$} & 실시 & 15,839 & 11,280 & 4,559 & 56,644 & 34,301 & 22,343 \\
\hline & 미실시 & 140,045 & 97,399 & 42,645 & 17,911 & 11,332 & 6,579 \\
\hline \multirow{3}{*}{$\begin{array}{l}\text { 혼인 } \\
\text { 상태 }\end{array}$} & 미혼 & 130,504 & 90,480 & 40,024 & 86,240 & 52,137 & 34,102 \\
\hline & 기혼 & 24,772 & 17,648 & 7,123 & 13,570 & 8,503 & 5,067 \\
\hline & 기타 & 608 & 552 & 56 & 390 & 358 & 31 \\
\hline \multirow{2}{*}{ 자녀 } & 있음 & 42,501 & 30,342 & 12,159 & 6,982 & 4,171 & 2,811 \\
\hline & 없음 & 113,383 & 78,338 & 35,045 & 93,217 & 56,827 & 36,390 \\
\hline \multirow{4}{*}{$\begin{array}{l}\text { 가구 } \\
\text { 소득 }\end{array}$} & $\begin{array}{c}300 \text { 만원 } \\
\text { 미만 }\end{array}$ & 30,349 & 21,400 & 8,950 & 18,788 & 12,091 & 6,697 \\
\hline & $\begin{array}{l}300-500 \\
\text { 만원 미만 }\end{array}$ & 62,650 & 42,653 & 19,997 & 39,919 & 23,262 & 16,657 \\
\hline & $\begin{array}{c}\text { 500만원 } \\
\text { 이상 }\end{array}$ & 62,884 & 44,627 & 18,257 & 41,492 & 25,646 & 15,847 \\
\hline & 무응답 & - & - & - & - & - & - \\
\hline
\end{tabular}




\section{5) 1 인 평균 여행 일수}

2020년 기준 청년층 1 인당 평균 국내여행 일수는 9.32일로 전체 국민의 7.65일 대비 1.67 일 많은 것으로 나타났다. 2020년에는 전년대비 전반적으로 여행 일수가 감소한 가운데 전체 국민은 평균 5.29 일 감소하였으며, 청년층은 4.84 일 감소한 것으로 확인되 었다. 특히 청년층의 경우 관광 숙박여행의 감소가 두드러지게 나타났는데, 청년층의 관 광 숙박여행은 2019년 7.98일 대비 3.33일 감소한 4.65일로 확인되었다.

\section{〈표 3-12〉1인 평균 여행 일수}

[단위: 일]

\begin{tabular}{|c|c|c|c|c|c|}
\hline \multirow{2}{*}{\multicolumn{2}{|c|}{ 구분 }} & \multicolumn{2}{|c|}{ 2019년 } & \multicolumn{2}{|c|}{ 2020년 } \\
\hline & & 전체 & 청년층 & 전체 & 청년층 \\
\hline \multirow{3}{*}{$\begin{array}{l}\text { 국내 } \\
\text { 여행 }\end{array}$} & 전체 & 12.94 & 14.17 & 7.65 & 9.32 \\
\hline & 숙박여행 & 8.91 & 9.88 & 4.64 & 5.68 \\
\hline & 당일여행 & 4.03 & 4.29 & 3.01 & 3.65 \\
\hline \multirow{3}{*}{$\begin{array}{l}\text { 관광 } \\
\text { 여행 }\end{array}$} & 전체 & 10.01 & 11.30 & 5.81 & 7.49 \\
\hline & 숙박여행 & 7.05 & 7.98 & 3.58 & 4.65 \\
\hline & 당일여행 & 2.95 & 3.33 & 2.24 & 2.84 \\
\hline \multirow{3}{*}{$\begin{array}{l}\text { 기타 } \\
\text { 여행 }\end{array}$} & 전체 & 2.93 & 2.86 & 1.83 & 1.83 \\
\hline & 숙박여행 & 1.85 & 1.90 & 1.07 & 1.02 \\
\hline & 당일여행 & 1.08 & 0.96 & 0.77 & 0.81 \\
\hline
\end{tabular}

청년층 내 세분집단별 1 인 평균 여행 일수를 살펴보면 2019년에는 여성(15.18일), 30 대 이상(14.88일), 경제활동자(14.42일), 전업주부(19.06일), 주5일 근무제 시행 사 업장의 직장인(15.06일), 기혼 가구(15.69일), 자녀동반 가구(16.24일) 등에서 평균 대 비 여행 일수가 많은 것으로 나타났다. 그러나 2020년에는 30대 이상(10.15일), 경제활 동자(10.05일), 주5일 근무제 시행 사업장의 직장인(10.84일) 등이 평균 대비 많은 여행 일수를 나타내는 가운데. 전업주부(7.27일), 기혼 가구(9.49일), 자녀동반 가구(8.61일) 등의 여행 일수는 전년 대비 큰 폭으로 감소하였다. 
〈표 3-13〉 청년층 특성별 1인 평균 국내여행 일수

[단위: 일]

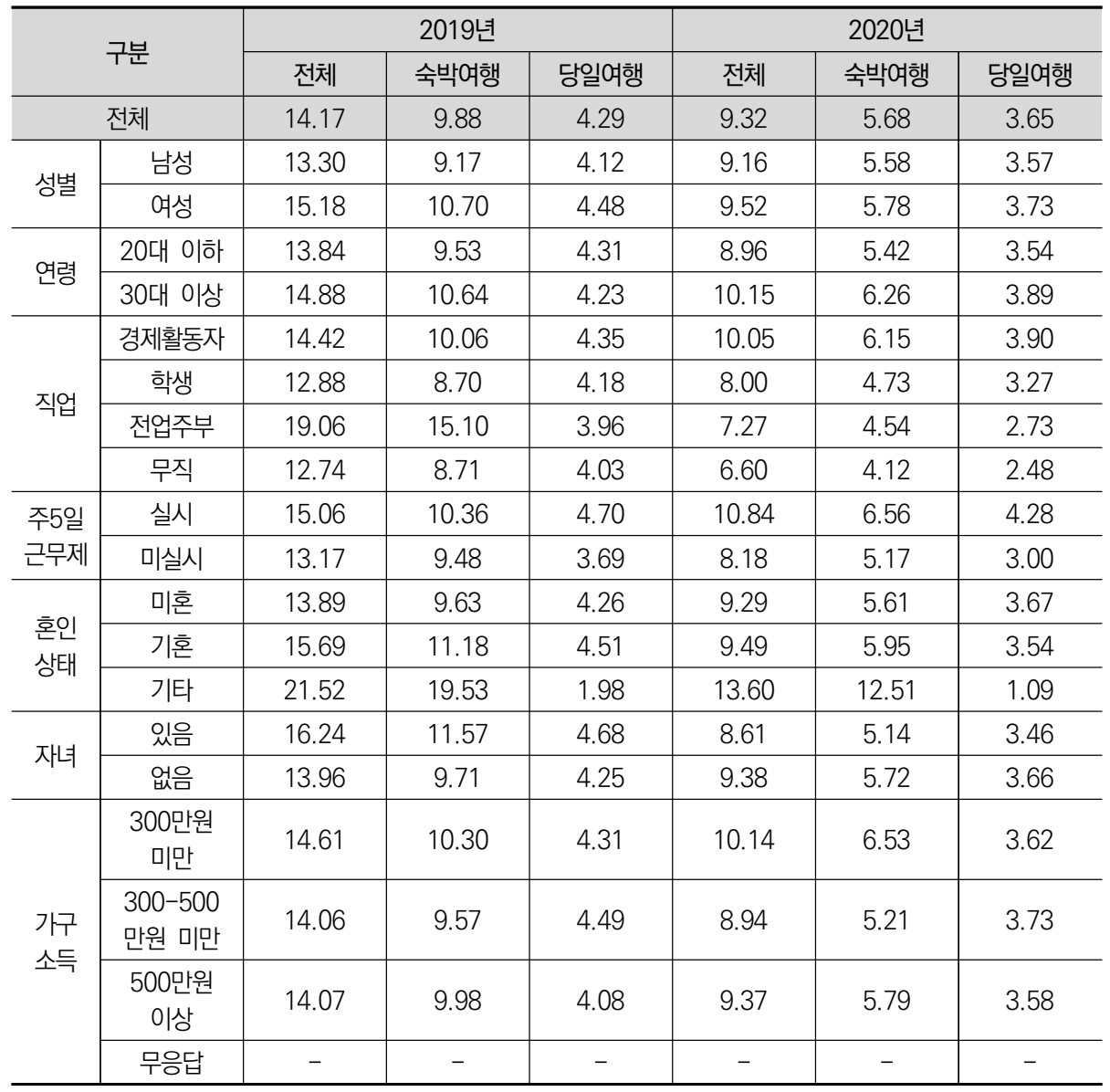

\section{6) 여행 지출액}

2020년 기준 청년층의 여행 지출액은 7 조 3,710 억 원으로 전체 국민 여행 지출 24 조 1,210 억 원 중 $30.6 \%$ 를 차지하는 것으로 확인되었다. 2020 년 전체 국내여행 지출액 은 2019년 대비 크게 감소한 가운데 전체 국민은 $45.4 \%$, 청년층은 $40.1 \%$ 감소하였 다. 여행 유형별로 살펴보면 전체 국민은 관광 숙박여행에서의 감소율이 $48.9 \%$ 로 가 장 높은 반면, 청년층은 기타 숙박여행의 감소율이 $50.8 \%$ 로 가장 높은 것으로 확인되 었으며, 기타여행을 제외한 모든 여행 유형에서 전체 국민 대비 청년층의 감소율이 상 대적으로 낮은 것으로 조사되었다. 
〈표 3-14〉전체 여행 지출액

[단위: 십억 원, \%]

\begin{tabular}{|c|c|c|c|c|c|}
\hline \multirow{2}{*}{\multicolumn{2}{|c|}{ 구분 }} & \multicolumn{2}{|c|}{ 2019년 } & \multicolumn{2}{|c|}{ 2020년 } \\
\hline & & \multirow{2}{*}{$\begin{array}{c}\text { 전체 } \\
44,183\end{array}$} & \multirow{2}{*}{$\begin{array}{c}\text { 청년층 } \\
12,305\end{array}$} & \multirow{2}{*}{$\frac{\text { 전체 }}{24,121}$} & \multirow{2}{*}{$\begin{array}{l}\text { 청년층 } \\
7,371\end{array}$} \\
\hline \multirow{3}{*}{$\begin{array}{l}\text { 국내 } \\
\text { 여행 }\end{array}$} & 전체 & & & & \\
\hline & 숙박여행 & 30,041 & 8,500 & 15,638 & 4,863 \\
\hline & 당일여행 & 14,142 & 3,805 & 8,483 & 2,508 \\
\hline \multirow{3}{*}{$\begin{array}{l}\text { 관광 } \\
\text { 여행 }\end{array}$} & 전체 & 38,015 & 10,782 & 20,213 & 6,488 \\
\hline & 숙박여행 & 26,580 & 7,599 & 13,579 & 4,420 \\
\hline & 당일여행 & 11,435 & 3,183 & 6,633 & 2,068 \\
\hline \multirow{3}{*}{$\begin{array}{l}\text { 기타 } \\
\text { 여행 }\end{array}$} & 전체 & 6,168 & 1,523 & 3,908 & 883 \\
\hline & 숙박여행 & 3,460 & 901 & 2,058 & 443 \\
\hline & 당일여행 & 2,707 & 622 & 1,850 & 440 \\
\hline
\end{tabular}

〈표 3-15〉 청년층 특성별 국내여행 지출액

\begin{tabular}{|c|c|c|c|c|c|c|c|}
\hline & \multirow{2}{*}{ 구분 } & \multicolumn{3}{|c|}{ 2019년 } & \multicolumn{3}{|c|}{ 2020년 } \\
\hline & & 전체 & 숙박여행 & 당일여행 & 전체 & 숙박여행 & 당일여행 \\
\hline \multicolumn{2}{|c|}{ 전체 } & 12,305 & 8,500 & 3,805 & 7,371 & 4,863 & 2,508 \\
\hline \multirow{2}{*}{ 성별 } & 남성 & 6,096 & 4,165 & 1,931 & 3,788 & 2,499 & 1,289 \\
\hline & 여성 & 6,209 & 4,335 & 1,874 & 3,583 & 2,364 & 1,219 \\
\hline \multirow{2}{*}{ 연령 } & 20대 이하 & 8,262 & 5,643 & 2,619 & 4,716 & 3,047 & 1,669 \\
\hline & 30대 이상 & 4,043 & 2,857 & 1,186 & 2,654 & 1,816 & 838 \\
\hline \multirow{4}{*}{ 직업 } & 경제활동자 & 9,235 & 6,426 & 2,809 & 5,799 & 3,887 & 1,911 \\
\hline & 학생 & 2,181 & 1,448 & 733 & 1,192 & 717 & 475 \\
\hline & 전업주부 & 427 & 320 & 107 & 151 & 107 & 44 \\
\hline & 무직 & 462 & 305 & 157 & 229 & 152 & 77 \\
\hline \multirow{2}{*}{$\begin{array}{l}\text { 주5일 } \\
\text { 근무제 }\end{array}$} & 실시 & 6,430 & 4,447 & 1,984 & 4,458 & 2,975 & 1,483 \\
\hline & 미실시 & 2,805 & 1,980 & 825 & 1,341 & 912 & 428 \\
\hline \multirow{3}{*}{$\begin{array}{l}\text { 혼인 } \\
\text { 상태 }\end{array}$} & 미혼 & 10,475 & 7,237 & 3,238 & 6,405 & 4,202 & 2,203 \\
\hline & 기혼 & 1,753 & 1,190 & 562 & 931 & 628 & 304 \\
\hline & 기타 & 77 & 72 & 5 & 35 & 33 & 1 \\
\hline \multirow{2}{*}{ 자녀 } & 있음 & 1,018 & 666 & 352 & 420 & 264 & 156 \\
\hline & 없음 & 11,287 & 7,834 & 3,453 & 6,951 & 4,599 & 2,352 \\
\hline \multirow{4}{*}{$\begin{array}{l}\text { 가구 } \\
\text { 소득 }\end{array}$} & $\begin{array}{c}\text { 300만원 } \\
\text { 미만 }\end{array}$ & 2,283 & 1,571 & 712 & 1,270 & 832 & 439 \\
\hline & $\begin{array}{l}300-500 \\
\text { 만원 미만 }\end{array}$ & 4,807 & 3,215 & 1,593 & 2,807 & 1,776 & 1,031 \\
\hline & $\begin{array}{c}\text { 500만원 } \\
\text { 이상 }\end{array}$ & 5,215 & 3,715 & 1,500 & 3,294 & 2,255 & 1,038 \\
\hline & 무응답 & - & - & - & - & - & - \\
\hline
\end{tabular}




\section{7) 1 인 평균 여행 지출액}

2020 년 기준 청년층 1 인 평균 여행 지출액은 68 만 6,000 원으로 전체 국민의 53 만 원 15만 6천원 많은 것으로 나타났다. 2019년과 비교하여 전반적으로 1 인 평균 여행 지출액이 감소한 가운데 전체 국민의 1 인 평균 여행 지출액은 $45.7 \%$ 감소하였고, 청년 층의 1 인 평균 여행 지출액은 $38.7 \%$ 감소하여 청년층의 감소폭이 상대적으로 적은 것으 로 조사되었다.

여행 유형별로 살펴보면 여행 지출액과 마찬가지로 전체 국민은 관광 숙박여행에서의 감소율이 $49.1 \%$ 로 가장 높은 반면, 청년층은 기타 숙박여행의 감소율이 $50.0 \%$ 로 가장 높은 것으로 확인되었다.

〈표 3-16〉1인 평균 여행 지출액

[단위: 천 원]

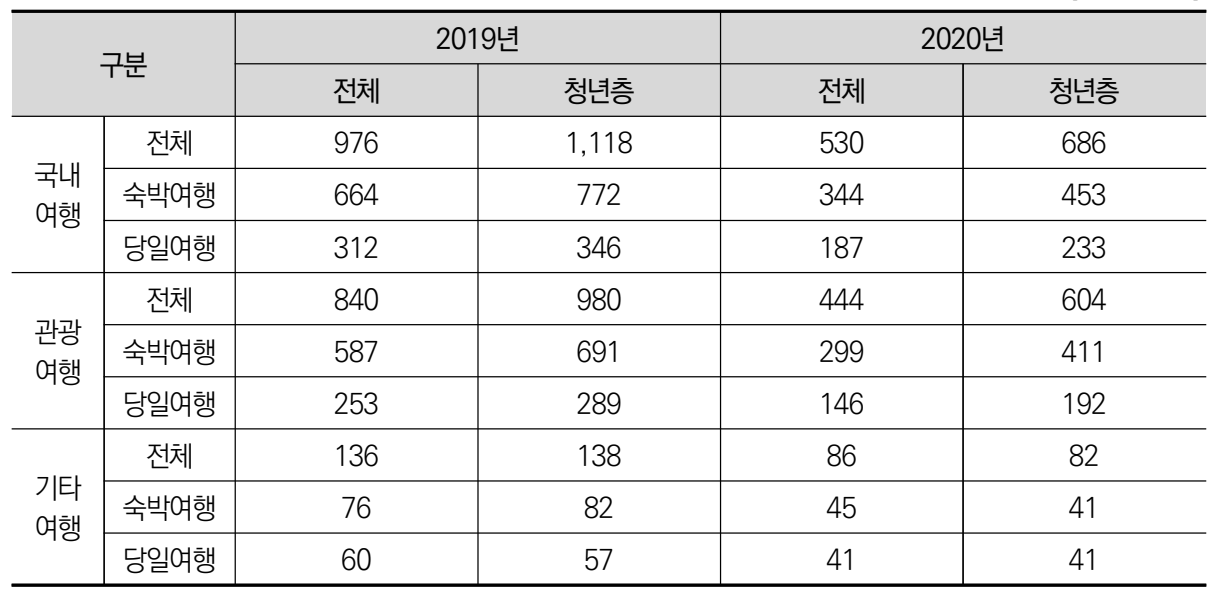

청년층 세분집단별 특성을 살펴보면 여성, 30 대 이상, 경제활동자, 주5일 근무제 시행 사업장의 직장인, 자녀 없는 가구 등에서 상대적으로 1 인 평균 지출비용이 높은 것으로 나타났으나, 2020년에는 전업주부 및 무직자의 지출액이 전년 대비 큰 폭으로 감소한 것으로 조사되었다. 
〈표 3-17〉 청년층 특성별 1인 평균 국내여행 지출액

[단위: 천 원]

\begin{tabular}{|c|c|c|c|c|c|c|c|}
\hline & \multirow{2}{*}{ 구분 } & \multicolumn{3}{|c|}{ 2019년 } & \multicolumn{3}{|c|}{ 2020년 } \\
\hline & & 전체 & 숙박여행 & 당일여행 & 전체 & 숙박여행 & 당일여행 \\
\hline \multicolumn{2}{|c|}{ 전체 } & 1,118 & 772 & 346 & 686 & 453 & 233 \\
\hline \multirow{2}{*}{ 성별 } & 남성 & 1,028 & 702 & 326 & 656 & 432 & 223 \\
\hline & 여성 & 1,224 & 854 & 369 & 721 & 476 & 245 \\
\hline \multirow{2}{*}{ 연령 } & 20대 이하 & 1,091 & 745 & 346 & 631 & 407 & 223 \\
\hline & 30대 이상 & 1,178 & 833 & 346 & 813 & 556 & 257 \\
\hline \multirow{4}{*}{ 직업 } & 경제활동자 & 1,185 & 825 & 361 & 782 & 524 & 258 \\
\hline & 학생 & 917 & 609 & 308 & 482 & 290 & 192 \\
\hline & 전업주부 & 1,180 & 884 & 296 & 469 & 332 & 137 \\
\hline & 무직 & 978 & 646 & 331 & 427 & 283 & 144 \\
\hline \multirow{2}{*}{$\begin{array}{l}\text { 주5일 } \\
\text { 근무제 }\end{array}$} & 실시 & 1,252 & 866 & 386 & 853 & 569 & 284 \\
\hline & 미실시 & 1,057 & 746 & 311 & 612 & 417 & 196 \\
\hline \multirow{3}{*}{$\begin{array}{l}\text { 혼인 } \\
\text { 상태 }\end{array}$} & 미혼 & 1,115 & 770 & 345 & 690 & 452 & 237 \\
\hline & 기혼 & 1,110 & 754 & 356 & 651 & 439 & 212 \\
\hline & 기타 & 2,744 & 2,566 & 177 & 1,211 & 1,167 & 44 \\
\hline \multirow{2}{*}{ 자녀 } & 있음 & 1,044 & 683 & 361 & 517 & 325 & 192 \\
\hline & 없음 & 1,125 & 781 & 344 & 700 & 463 & 237 \\
\hline \multirow{4}{*}{$\begin{array}{l}\text { 가구 } \\
\text { 소득 }\end{array}$} & $\begin{array}{c}\text { 300만원 } \\
\text { 미만 }\end{array}$ & 1,099 & 756 & 343 & 686 & 449 & 237 \\
\hline & $\begin{array}{l}300-500 \\
\text { 만원 미만 }\end{array}$ & 1,079 & 721 & 357 & 629 & 398 & 231 \\
\hline & $\begin{array}{c}\text { 500만원 } \\
\text { 이상 }\end{array}$ & 1,166 & 831 & 336 & 744 & 509 & 234 \\
\hline & 무응답 & - & - & - & - & - & - \\
\hline
\end{tabular}




\section{나. 여행 행태}

\section{1) 여행 방문지}

2020년 기준 청년층이 가장 많이 방문한 국내관광 목적지는 경기도(21.8\%)이며, 이 어서 강원도(11.2\%)와 전라남도(9.4\%) 순으로 조사되었다. 이는 2019년의 경기도 (18.5\%), 강원도(15.3\%), 서울(11.1\%) 등의 조사 결과와 유사하나 경기도의 방문율이 증가한 반면 강원도와 서울의 방문율은 하락한 결과이다.

〈표 3-18〉여행 방문지

[단위: \%]

\begin{tabular}{c|c|c|c|c}
\hline \multirow{2}{*}{ 구분 } & \multicolumn{2}{|c|}{2019 년 } & \multicolumn{2}{c}{2020 년 } \\
\cline { 2 - 5 } & 건체 & 청년층 & 전체 & 청년층 \\
\hline 강원 & 17.4 & 18.5 & 21.9 & 21.8 \\
\hline 경북 & 13.6 & 15.3 & 10.8 & 11.2 \\
\hline 경남 & 9.9 & 8.5 & 8.0 & 6.3 \\
\hline 충남 & 9.7 & 7.3 & 10.3 & 8.7 \\
\hline 전남 & 9.4 & 8.5 & 9.5 & 8.6 \\
\hline 서울 & 8.4 & 8.2 & 9.5 & 9.4 \\
\hline 전북 & 7.5 & 11.1 & 6.2 & 8.6 \\
\hline 부산 & 6.3 & 6.9 & 6.7 & 6.4 \\
\hline 충북 & 4.9 & 8.9 & 5.0 & 6.5 \\
\hline 인천 & 4.9 & 3.4 & 4.9 & 3.8 \\
\hline 제주 & 4.2 & 5.4 & 4.6 & 4.8 \\
\hline 대전 & 3.0 & 5.1 & 4.1 & 4.1 \\
\hline 대구 & 2.6 & 3.2 & 2.6 & 2.8 \\
\hline 울산 & 1.9 & 2.9 & 1.7 & 1.9 \\
\hline 광주 & 1.7 & 1.6 & 1.9 & 1.6 \\
\hline 세종 & 0.9 & 0.9 & 1.1 & 1.3 \\
\hline
\end{tabular}


〈표 3-19〉 청년층 특성별 여행 방문지(상위 3개 항목)

[단위: \%]

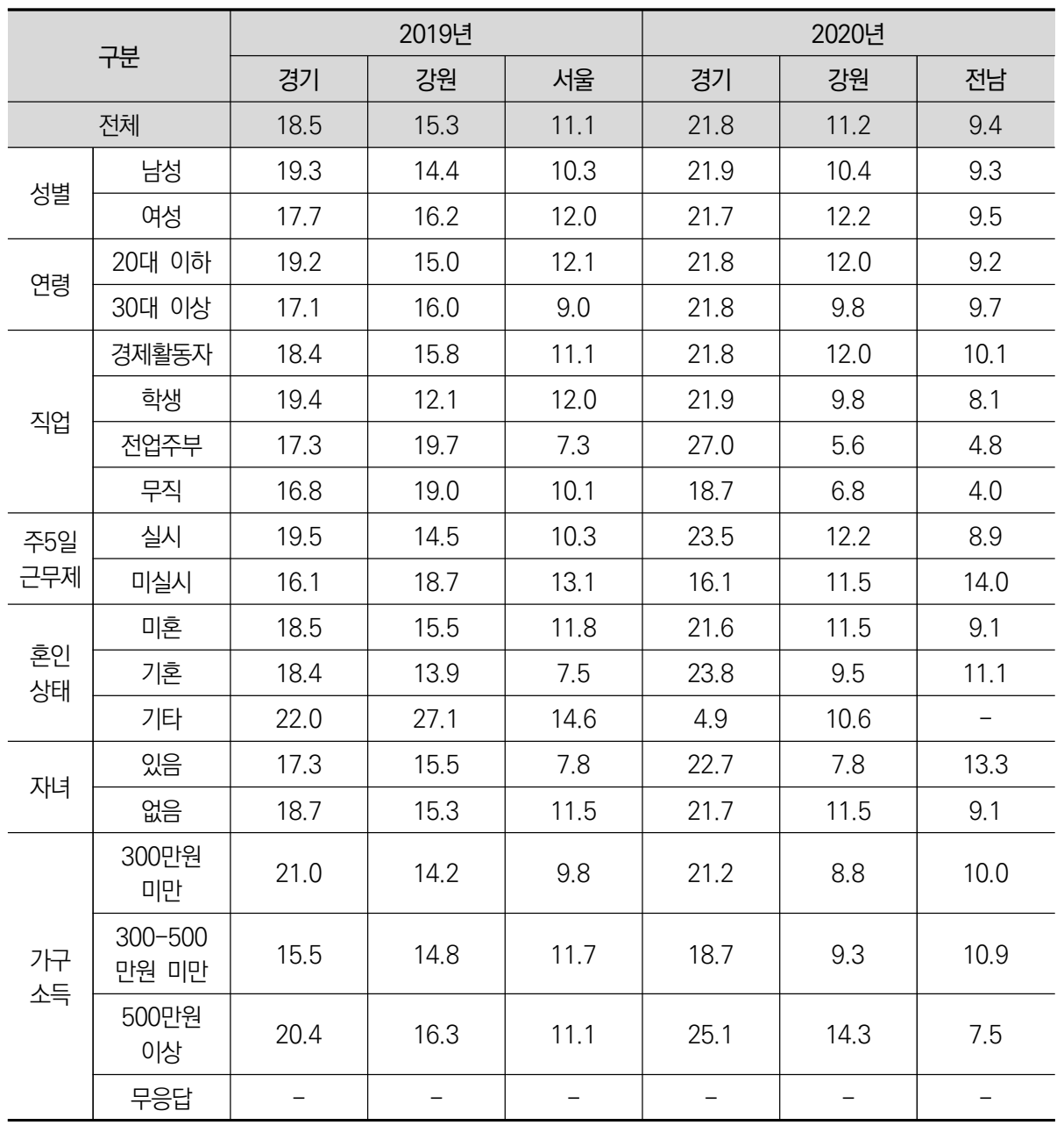

\section{2) 여행 방문지 선택 이유}

2020년 기준 청년층의 주된 여행방문지 선택 이유는 볼거리 제공(19.8\%)이며, 그 외 에도 여행지 지명도(16.9\%), 이동거리(13.2\%) 등이 주로 고려되는 것으로 나타났다. 전 체 국민과 청년층 간 응답의 차이는 크지 않으나 전반적으로 이동거리와 여행할 수 있는 시간에 대한 응답이 2019년 대비 증가한 것으로 나타났다.

청년층 내 세분집단별 응답의 차이는 크지 않으나, 학생과 전업주부에서 '여행지 지명 도' 응답 비중이 상대적으로 높은 것으로 확인되었다. 
〈표 3-20〉 여행 방문지 선택 이유(상위 10개 항목)

\begin{tabular}{c|c|c|c|c}
\hline \multirow{2}{*}{ 구분 } & \multicolumn{2}{|c|}{ 2019년 } & \multicolumn{2}{c}{ 2020년 } \\
\cline { 2 - 5 } & 전체 & 청년층 & 전체 & 기준, 단위: \% $]$ \\
\hline 볼거ㄴㅡㅡㅇㅣ 제공 & 19.6 & 20.9 & 18.6 & 19.8 \\
\hline 여행지 지명도 & 18.2 & 18.3 & 16.4 & 16.9 \\
\hline 이동거리 & 10.3 & 10.9 & 12.6 & 13.2 \\
\hline 여행할 수 있는 시간 & 9.5 & 8.8 & 12.4 & 12.1 \\
\hline 여행 동반자 유형 & 9.4 & 8.5 & 8.4 & 8.2 \\
\hline 음식 & 7.6 & 6.7 & 7.9 & 7.1 \\
\hline 저렴한 여행 경비 & 5.5 & 5.9 & 6.0 & 5.9 \\
\hline 경험자 추천 & 6.5 & 6.4 & 5.6 & 5.4 \\
\hline 숙박시설 & 2.5 & 1.9 & 3.5 & 2.8 \\
\hline 교통편 & 3.7 & 3.9 & 2.6 & 3.0 \\
\hline
\end{tabular}

〈표 3-21〉 청년층 특성별 여행 방문지 선택 이유(상위 3개 항목)

[단위: \%]

\begin{tabular}{|c|c|c|c|c|c|c|c|}
\hline & \multirow{2}{*}{ 구분 } & \multicolumn{3}{|c|}{ 2019년 } & \multicolumn{3}{|c|}{ 2020년 } \\
\hline & & 볼거리 제공 & 여행지지명도 & 이동거리 & 볼거리 제공 & 여행지지명도 & 이동거리 \\
\hline \multicolumn{2}{|c|}{ 전체 } & 20.9 & 18.3 & 10.9 & 19.8 & 16.9 & 13.2 \\
\hline \multirow{2}{*}{ 성별 } & 남성 & 19.1 & 17.9 & 11.2 & 18.4 & 16.5 & 14.2 \\
\hline & 여성 & 22.7 & 18.6 & 10.6 & 21.3 & 17.2 & 12.2 \\
\hline \multirow{2}{*}{ 연령 } & 20 대 이하 & 22.1 & 18.8 & 10.1 & 20.5 & 16.8 & 13.9 \\
\hline & 30대 이상 & 18.2 & 17.0 & 12.7 & 18.3 & 16.9 & 11.7 \\
\hline \multirow{4}{*}{ 직업 } & 경제활동자 & 20.7 & 17.6 & 11.6 & 20.0 & 16.3 & 13.5 \\
\hline & 학생 & 21.6 & 18.3 & 9.5 & 20.6 & 19.0 & 13.1 \\
\hline & 전업주부 & 23.1 & 25.0 & 8.7 & 19.1 & 20.9 & 10.0 \\
\hline & 무직 & 17.8 & 23.0 & 8.3 & 11.4 & 14.3 & 10.1 \\
\hline \multirow{2}{*}{$\begin{array}{l}\text { 주5일 } \\
\text { 근무제 }\end{array}$} & 실시 & 19.1 & 17.8 & 12.0 & 20.9 & 15.8 & 13.9 \\
\hline & 미실시 & 21.5 & 18.4 & 10.5 & 17.0 & 17.6 & 12.2 \\
\hline \multirow{3}{*}{$\begin{array}{l}\text { 혼인 } \\
\text { 상태 }\end{array}$} & 미혼 & 21.3 & 18.6 & 10.8 & 20.2 & 17.0 & 13.3 \\
\hline & 기혼 & 18.6 & 16.5 & 11.6 & 17.2 & 15.8 & 12.6 \\
\hline & 기타 & 17.5 & 24.0 & 9.7 & 19.0 & 19.2 & 6.5 \\
\hline \multirow{2}{*}{ 자녀 } & 있음 & 17.4 & 15.8 & 11.8 & 17.8 & 15.7 & 13.0 \\
\hline & 없음 & 21.3 & 18.5 & 10.8 & 20.0 & 16.9 & 13.2 \\
\hline \multirow{4}{*}{$\begin{array}{l}\text { 가구 } \\
\text { 소득 }\end{array}$} & $\begin{array}{c}\text { 300만원 } \\
\text { 미만 }\end{array}$ & 20.3 & 18.0 & 11.3 & 18.5 & 15.1 & 13.2 \\
\hline & $\begin{array}{l}300-500 \\
\text { 만원 미만 }\end{array}$ & 21.7 & 19.0 & 11.2 & 20.3 & 17.8 & 13.0 \\
\hline & $\begin{array}{c}\text { 500만원 } \\
\text { 이상 }\end{array}$ & 20.3 & 17.6 & 10.4 & 19.8 & 16.7 & 13.5 \\
\hline & 무응답 & - & - & - & - & - & - \\
\hline
\end{tabular}




\section{3) 여행 정보 획득 경로}

2020년 기준 청년층의 주된 여행 정보 획득 경로는 과거 방문 경험이며, 전체 국민과 비교하여 유사한 결과를 나타내었다. 2019년과 비교할 경우 전반적으로 주변인에 대한 의존도가 감소한 반면, 과거 방문 경험에 대한 응답 비율은 다소 증가하였다. 청년층에 게서 특징적으로 드러나는 여행정보 획득 경로는 인터넷 사이트/모바일 앱(20.0\%)으로 전체 국민(12.5\%) 대비 상대적 비중이 높을 뿐만 아니라 전년대비 응답비율이 $2.9 \% \mathrm{p}$ 증가한 것으로 조사되었다.

〈표 3-22〉 여행 정보 획득 경로

[1순위 기준, 단위: \%]

\begin{tabular}{c|c|c|c|c}
\hline \multirow{2}{*}{ 구분 } & \multicolumn{2}{|c|}{2019 년 } & \multicolumn{2}{c}{2020 년 } \\
\cline { 2 - 5 } & 전체 & 청년층 & 전체 & 청년층 \\
\hline 과거 방문 경험 & 28.3 & 26.6 & 32.9 & 29.0 \\
\hline 주변인 & 39.0 & 37.4 & 29.1 & 28.5 \\
\hline $\begin{array}{c}\text { 인터넷 } \\
\text { 사이트/모바일 앱 }\end{array}$ & 11.2 & 17.1 & 12.5 & 20.0 \\
\hline $\begin{array}{c}\text { 기사 및 방송 } \\
\text { 프로그램 }\end{array}$ & 2.6 & 2.6 & 2.1 & 2.2 \\
\hline 광고 & 2.6 & 2.5 & 1.7 & 1.8 \\
\hline 관광 안내 서적 & 0.8 & 0.9 & 0.4 & 0.5 \\
\hline 여행사 & 0.8 & 0.5 & 0.3 & 0.3 \\
\hline 기타 & 0.3 & 0.2 & 0.1 & 0.1 \\
\hline 정보 없이 방문 & 14.3 & 12.1 & 20.9 & 17.7 \\
\hline
\end{tabular}

세분집단별로 살펴보면 '과거 방문 경험'은 전업주부(36.8\%)에서 높은 것으로 나타났 으며, 직업이 무직인 청년층의 '과거 방문 경험' 및 '인터넷 사이트/모바일 앱’ 이용률 전년 대비 크게 감소하였다. 
〈표 3-23〉 청년층 특성별 여행 정보 획득 경로(상위 3개 항목)

[단위: \%]

\begin{tabular}{|c|c|c|c|c|c|c|c|}
\hline \multirow[b]{2}{*}{ 구분 } & \multirow[b]{2}{*}{ 구분 } & \multicolumn{3}{|c|}{ 2019년 } & \multicolumn{3}{|c|}{ 2020년 } \\
\hline & & 주변인 & $\begin{array}{c}\text { 과거 방문 경 } \\
\text { 험 }\end{array}$ & $\begin{array}{l}\text { 인터넷 사이 } \\
\text { 트/모바일 앱 }\end{array}$ & $\begin{array}{c}\text { 과거 방문 경 } \\
\text { 험 }\end{array}$ & 주변인 & $\begin{array}{l}\text { 인터넷 사이 } \\
\text { 트/모바일 앱 }\end{array}$ \\
\hline \multicolumn{2}{|c|}{ 전체 } & 37.4 & 26.6 & 17.1 & 29.0 & 28.5 & 20.0 \\
\hline \multirow{2}{*}{ 성별 } & 남성 & 37.5 & 28.1 & 15.6 & 31.3 & 26.9 & 18.6 \\
\hline & 여성 & 37.4 & 25.0 & 18.6 & 26.5 & 30.1 & 21.5 \\
\hline \multirow{2}{*}{ 연령 } & 20대 이하 & 37.7 & 25.9 & 17.5 & 28.6 & 29.4 & 21.0 \\
\hline & 30대 이상 & 36.7 & 28.1 & 16.3 & 29.7 & 26.3 & 17.6 \\
\hline \multirow{4}{*}{ 직업 } & 경제활동자 & 37.7 & 26.1 & 17.3 & 28.7 & 27.9 & 20.9 \\
\hline & 학생 & 39.3 & 24.9 & 16.8 & 30.0 & 31.2 & 16.5 \\
\hline & 전업주부 & 24.9 & 38.2 & 20.4 & 36.8 & 26.6 & 15.7 \\
\hline & 무직 & 34.9 & 32.5 & 12.8 & 24.3 & 25.5 & 24.4 \\
\hline \multirow{2}{*}{$\begin{array}{l}\text { 주5일 } \\
\text { 근무제 }\end{array}$} & 실시 & 37.7 & 25.3 & 17.7 & 29.0 & 28.2 & 20.5 \\
\hline & 미실시 & 37.7 & 27.9 & 16.2 & 27.7 & 26.8 & 22.1 \\
\hline \multirow{3}{*}{$\begin{array}{l}\text { 혼인 } \\
\text { 상태 }\end{array}$} & 미혼 & 38.3 & 25.9 & 17.5 & 28.7 & 29.4 & 20.5 \\
\hline & 기혼 & 32.4 & 30.5 & 15.1 & 31.2 & 21.9 & 16.7 \\
\hline & 기타 & 42.2 & 11.7 & 7.5 & 23.6 & 23.1 & 19.1 \\
\hline \multirow{2}{*}{ 자녀 } & 있음 & 35.4 & 28.0 & 14.8 & 32.2 & 24.2 & 12.8 \\
\hline & 없음 & 37.6 & 26.4 & 17.4 & 28.7 & 28.7 & 20.5 \\
\hline \multirow{4}{*}{$\begin{array}{l}\text { 가구 } \\
\text { 소득 }\end{array}$} & $\begin{array}{c}\text { 300만원 } \\
\text { 미만 }\end{array}$ & 39.8 & 28.8 & 15.7 & 28.7 & 28.7 & 18.7 \\
\hline & $\begin{array}{l}300-500 \\
\text { 만원 미만 }\end{array}$ & 35.7 & 27.2 & 16.9 & 28.8 & 28.4 & 20.1 \\
\hline & $\begin{array}{c}\text { 500만원 } \\
\text { 이상 }\end{array}$ & 38.1 & 24.9 & 18.0 & 29.2 & 28.4 & 20.5 \\
\hline & 무응답 & - & - & - & - & - & - \\
\hline
\end{tabular}

\section{4) 이용한 인터넷 사이트}

2020년 기준 청년층이 주요 이용한 인터넷 사이트는 포털사이트(65.2\%)로 전체 국민 과 유사한 결과로 조사되었다. 그러나 청년층은 전체 국민과 비교해 SNS의 이용률이 상 대적으로 높았으며, 동영상 사이트 또한 선호하는 것으로 나타났다.

이용한 인터넷 사이트와 관련하여 청년층 내 세분집단별로 뚜렷한 차이는 발견되지 않았으나 전업주부의 경우 포털사이트(77.1\%)에 대한 이용율이 특히 높은 것으로 나타 났으며, 2019년 대비 21.6\%p 증가한 것으로 조사되었다. 
〈표 3-24〉 이용한 인터넷 사이트

[1순위 기준, 단위: \%]

\begin{tabular}{c|c|c|c|c}
\hline \multirow{2}{*}{ 구분 } & \multicolumn{2}{|c|}{2019 년 } & \multicolumn{2}{c}{ 2020년 } \\
\cline { 2 - 5 } & 전체 & 청년층 & 전체 & 청년층 \\
\hline 포털사이트 & 62.6 & 58.1 & 68.6 & 65.2 \\
\hline 여행 관련 블로그 & 13.7 & 13.4 & 11.1 & 10.0 \\
\hline SNS & 12.1 & 16.4 & 10.7 & 14.4 \\
\hline 동영상 사이트 & 5.1 & 6.6 & 4.5 & 5.3 \\
\hline 여행 및 숙박전문사이트 또는 앱 & 2.5 & 2.5 & 2.8 & 3.0 \\
\hline 공공기관 홈페이지 & 2.1 & 1.4 & 1.0 & 0.8 \\
\hline 개별 관광지 또는 관광시설 & 1.1 & 1.0 & 1.0 & 1.3 \\
\hline 홈페이지 & 0.7 & 0.6 & 0.3 & 0.1 \\
\hline 여행사 홈페이지 & 0.1 & - & - & - \\
\hline 기타 & & &
\end{tabular}

〈표 3-25〉 청년층 특성별 이용한 인터넷 사이트(상위 3개 항목)

\begin{tabular}{|c|c|c|c|c|c|c|c|}
\hline & \multirow[b]{2}{*}{ 구분 } & \multicolumn{3}{|c|}{ 2019년 } & \multicolumn{3}{|c|}{ 2020년 } \\
\hline & & $\begin{array}{l}\text { 포털 } \\
\text { 사이트 }\end{array}$ & SNS & $\begin{array}{c}\text { 여행 관련 } \\
\text { 블로그 }\end{array}$ & $\begin{array}{l}\text { 포털 } \\
\text { 사이트 }\end{array}$ & SNS & $\begin{array}{c}\text { 여행 관련 } \\
\text { 블로그 }\end{array}$ \\
\hline \multicolumn{2}{|r|}{ 전체 } & 58.1 & 16.4 & 13.4 & 65.2 & 14.4 & 10.0 \\
\hline \multirow{2}{*}{ 성별 } & 남성 & 60.5 & 14.8 & 12.7 & 64.8 & 14.7 & 11.1 \\
\hline & 여성 & 56.0 & 17.9 & 14.1 & 65.6 & 14.1 & 9.0 \\
\hline \multirow{2}{*}{ 연령 } & 20대 이하 & 59.7 & 16.8 & 13.5 & 64.4 & 15.1 & 10.2 \\
\hline & 30대 이상 & 54.3 & 15.4 & 13.1 & 67.3 & 12.6 & 9.5 \\
\hline \multirow{4}{*}{ 직업 } & 경제활동자 & 58.6 & 16.2 & 12.8 & 64.7 & 14.4 & 10.8 \\
\hline & 학생 & 57.8 & 16.6 & 13.2 & 69.1 & 15.2 & 6.9 \\
\hline & 전업주부 & 55.5 & 14.9 & 26.2 & 77.1 & 6.7 & 6.0 \\
\hline & 무직 & 54.0 & 20.3 & 13.7 & 51.5 & 14.8 & 10.1 \\
\hline \multirow{2}{*}{$\begin{array}{l}\text { 주5일 } \\
\text { 근무제 }\end{array}$} & 실시 & 55.6 & 17.6 & 13.9 & 65.2 & 13.6 & 10.6 \\
\hline & 미실시 & 66.3 & 12.7 & 10.0 & 63.1 & 17.1 & 11.5 \\
\hline \multirow{3}{*}{$\begin{array}{l}\text { 혼인 } \\
\text { 상태 }\end{array}$} & 미혼 & 58.5 & 16.6 & 12.7 & 64.9 & 14.7 & 10.0 \\
\hline & 기혼 & 55.2 & 14.7 & 18.2 & 67.7 & 11.4 & 10.8 \\
\hline & 기타 & 55.0 & - & - & 85.1 & 14.9 & - \\
\hline \multirow{2}{*}{ 자녀 } & 있음 & 55.7 & 14.3 & 20.9 & 66.6 & 12.2 & 9.6 \\
\hline & 없음 & 58.3 & 16.6 & 12.8 & 65.2 & 14.5 & 10.0 \\
\hline \multirow{4}{*}{$\begin{array}{l}\text { 가구 } \\
\text { 소득 }\end{array}$} & $\begin{array}{c}\text { 300만원 } \\
\text { 미만 }\end{array}$ & 59.7 & 15.0 & 12.4 & 69.6 & 17.6 & 5.8 \\
\hline & $\begin{array}{l}300-500 \\
\text { 만원 미만 }\end{array}$ & 61.1 & 14.9 & 13.8 & 70.4 & 11.1 & 7.8 \\
\hline & $\begin{array}{c}\text { 500만원 } \\
\text { 이상 }\end{array}$ & 54.6 & 18.4 & 13.5 & 58.5 & 16.4 & 13.8 \\
\hline & 무응답 & - & - & - & - & - & - \\
\hline
\end{tabular}




\section{5) 동반객 수 및 유형}

2020년 기준 청년층의 본인을 포함한 동반객 수는 2.9 명으로서, 전체 국민 대비 다소 적은 것으로 분석되었다. 2020년에는 전반적으로 전년대비 여행 동반객 수가 감소하였 으나 청년층은 상대적으로 소폭 감소하였다. 전체 국민의 경우, 가족(54.6\%)과 함께하는 비율이 가장 높은 반면, 청년층은 친구/연인(73.1\%)과 동반하는 경우가 3 분의 2 이상을 차지하였다.

〈표 3-26〉 동반객 수 및 유형

[단위: 명, \%]

\begin{tabular}{c|c|c|c|c|c}
\hline \multirow{2}{*}{\multicolumn{2}{c|}{ 구분 }} & \multicolumn{2}{c|}{2019 년 } & \multicolumn{2}{c}{2020 년 } \\
\cline { 3 - 6 } \multicolumn{2}{c|}{} & 전체 & 청년층 & 전체 & 청년층 \\
\hline 동반객 수 & 평균(명) & 4.3 & 3.2 & 3.2 & 2.9 \\
\hline \multirow{5}{*}{ 동반자 유형 } & 가족 & 55.1 & 27.5 & 54.6 & 23.0 \\
\cline { 2 - 6 } & 친구/연인 & 38.1 & 69.5 & 40.4 & 73.1 \\
\cline { 2 - 6 } & 친척 & 3.1 & 1.2 & 3.0 & 1.3 \\
\cline { 2 - 6 } & 친목 단체/모임 & 5.2 & 0.8 & 2.4 & 0.5 \\
\cline { 2 - 6 } & (직장)동료 & 2.2 & 2.1 & 2.0 & 3.2 \\
\cline { 2 - 6 } & 학교 단체 & 0.3 & 0.4 & - & 0.0 \\
\cline { 2 - 6 } & 기타 & 0.2 & 0.1 & 0.1 & 0.0 \\
\hline
\end{tabular}

〈표 3-27〉 청년층 특성별 동반객 수

[단위: 명]

\begin{tabular}{|c|c|c|c|}
\hline \multicolumn{2}{|r|}{ 구분 } & 2019년 & 2020년 \\
\hline \multicolumn{2}{|r|}{ 전체 } & 3.2 & 2.9 \\
\hline \multirow{2}{*}{ 성별 } & 남성 & 3.2 & 2.9 \\
\hline & 여성 & 3.1 & 2.9 \\
\hline \multirow{2}{*}{ 연령 } & 20대 이하 & 3.2 & 3.0 \\
\hline & 30대 이상 & 3.0 & 2.6 \\
\hline \multirow{4}{*}{ 직업 } & 경제활동자 & 2.9 & 2.7 \\
\hline & 학생 & 3.9 & 3.3 \\
\hline & 전업주부 & 3.6 & 3.3 \\
\hline & 무직 & 3.0 & 2.8 \\
\hline \multirow{2}{*}{$\begin{array}{l}\text { 주5일 } \\
\text { 근무제 }\end{array}$} & 실시 & 2.9 & 2.7 \\
\hline & 미실시 & 3.0 & 2.8 \\
\hline \multirow{3}{*}{$\begin{array}{l}\text { 혼인 } \\
\text { 상태 }\end{array}$} & 미혼 & 3.1 & 2.9 \\
\hline & 기혼 & 3.3 & 2.8 \\
\hline & 기타 & 2.3 & 2.6 \\
\hline
\end{tabular}


〈표 계속〉

\begin{tabular}{c|c|c|c}
\hline \multicolumn{2}{c|}{ 구분 } & 2019년 & 2020년 \\
\hline \multirow{3}{*}{ 자녀 } & 있음 & 3.7 & 3.4 \\
\cline { 2 - 4 } & 없음 & 3.1 & 2.8 \\
\hline \multirow{4}{*}{$\begin{array}{c}\text { 가구 } \\
\text { 소득 }\end{array}$} & 300만원 미만 & 2.9 & 2.6 \\
\cline { 2 - 4 } & $300-500$ 만원 미만 & 3.2 & 2.9 \\
\cline { 2 - 4 } & 500만원 이상 & 3.2 & 3.0 \\
\cline { 2 - 4 } & 무응답 & - & - \\
\hline
\end{tabular}

청년층 내 세분집단별 차이를 살펴보면 20대 이하 및 미혼인 경우 ‘친구/연인' 바율이 높은 반면, 전업주부와 기혼 및 자녀가 있는 경우는 '가족'의 바율이 $80 \%$ 이상을 차지하였다.

〈표 3-28〉 청년층 특성별 동반객 유형(상위 3개 항목)

[단위: \%]

\begin{tabular}{|c|c|c|c|c|c|c|c|}
\hline \multirow{2}{*}{\multicolumn{2}{|c|}{ 구분 }} & \multicolumn{3}{|c|}{ 2019년 } & \multicolumn{3}{|c|}{ 2020년 } \\
\hline & & $\begin{array}{l}\text { 친구/ } \\
\text { 연인 }\end{array}$ & 가족 & $\begin{array}{c}\text { (직장) } \\
\text { 동료 }\end{array}$ & $\begin{array}{l}\text { 친구/ } \\
\text { 연인 }\end{array}$ & 가족 & $\begin{array}{c}\text { (직장) } \\
\text { 동료 }\end{array}$ \\
\hline \multicolumn{2}{|r|}{ 전체 } & 69.5 & 27.5 & 2.1 & 73.1 & 23.0 & 3.2 \\
\hline \multirow{2}{*}{ 성별 } & 남성 & 73.8 & 23.1 & 1.7 & 75.4 & 19.8 & 3.8 \\
\hline & 여성 & 65.4 & 31.8 & 2.5 & 70.7 & 26.4 & 2.6 \\
\hline \multirow{2}{*}{ 연령 } & 20대 이하 & 77.5 & 19.0 & 2.2 & 79.1 & 17.5 & 2.6 \\
\hline & 30대 이상 & 51.3 & 46.8 & 2.0 & 59.2 & 35.9 & 4.5 \\
\hline \multirow{4}{*}{ 직업 } & 경제활동자 & 70.8 & 26.0 & 2.6 & 73.7 & 21.6 & 4.3 \\
\hline & 학생 & 74.5 & 21.9 & 1.3 & 77.2 & 21.0 & 0.1 \\
\hline & 전업주부 & 7.5 & 94.4 & - & 8.2 & 92.6 & - \\
\hline & 무직 & 81.7 & 17.6 & 0.4 & 77.1 & 20.4 & 0.4 \\
\hline \multirow{2}{*}{$\begin{array}{l}\text { 주5일 } \\
\text { 근무제 }\end{array}$} & 실시 & 71.2 & 25.4 & 2.9 & 73.2 & 21.8 & 5.0 \\
\hline & 미실시 & 69.7 & 27.6 & 1.8 & 75.3 & 21.1 & 2.2 \\
\hline \multirow{3}{*}{$\begin{array}{l}\text { 혼인 } \\
\text { 상태 }\end{array}$} & 미혼 & 79.4 & 17.1 & 2.3 & 82.0 & 13.8 & 3.3 \\
\hline & 기혼 & 15.3 & 84.6 & 1.0 & 11.2 & 86.8 & 2.4 \\
\hline & 기타 & 85.2 & 14.8 & - & 80.7 & 10.9 & 8.3 \\
\hline \multirow{2}{*}{ 자녀 } & 있음 & 12.2 & 87.5 & 1.0 & 8.2 & 90.2 & 1.8 \\
\hline & 없음 & 75.9 & 20.9 & 2.2 & 77.7 & 18.3 & 3.3 \\
\hline \multirow{4}{*}{$\begin{array}{l}\text { 가구 } \\
\text { 소득 }\end{array}$} & 300만원 미만 & 75.3 & 21.0 & 2.7 & 77.7 & 18.0 & 3.6 \\
\hline & 300-500만원 미만 & 65.9 & 31.8 & 1.7 & 69.2 & 27.8 & 2.3 \\
\hline & 500만원 이상 & 70.6 & 26.1 & 2.3 & 75.0 & 20.3 & 3.9 \\
\hline & 무응답 & - & - & - & - & - & - \\
\hline
\end{tabular}




\section{6) 여행지 활동}

2020년 기준 청년층의 주된 여행지 활동은 자연 및 풍경 감상으로 조사되었다. 청년 층의 여행지 활동의 경우 전체 국민과 큰 차이를 보이지는 않으나, '시티투어', '테마파 크, 놀이시설, 동/식물원 방문' 등에 대한 응답 비율이 상대적으로 높았으며, '가족/친지 /친구 방문' 응답 비율은 전체 국민 대비 상대적으로 낮은 것으로 확인되었다.

〈표 3-29〉여행지 활동(상위 10개 항목)

[단위: \%]

\begin{tabular}{c|c|c|c|c}
\hline \multirow{2}{*}{ 구분 } & \multicolumn{2}{|c|}{ 2019년 } & \multicolumn{2}{c}{ 2020년 } \\
\cline { 2 - 5 } & 전체 & 청년층 & 전체 & 청년층 \\
\hline 자연 및 풍경 감상 & 74.4 & 71.4 & 78.1 & 78.9 \\
\hline 휴식/휴양 & 56.3 & 56.9 & 57.6 & 59.5 \\
\hline 음식관광 & 51.9 & 52.8 & 53.9 & 55.9 \\
\hline 가족/친지/친구 방문 & 13.9 & 10.9 & 16.3 & 11.1 \\
\hline 쇼핑 & 7.7 & 9.6 & 7.8 & 8.5 \\
\hline 시티투어 & 5.2 & 6.4 & 5.9 & 8.5 \\
\hline 역사 유적지 방문 & 9.8 & 9.5 & 8.5 & 8.2 \\
\hline $\begin{array}{c}\text { 테마파크, 놀이시설, } \\
\text { 동/식물원 방문 }\end{array}$ & 8.0 & 10.6 & 5.5 & 7.3 \\
\hline $\begin{array}{c}\text { 야외 위락 및 스포츠, } \\
\text { 레포츠 활동 }\end{array}$ & 4.8 & 6.7 & 6.4 & 6.8 \\
\hline 드라마 촬영지 방문 & 4.2 & 5.8 & 3.7 & 4.1 \\
\hline
\end{tabular}

〈표 3-30〉 청년층 특성별 여행지 활동(상위 3개 항목)

[단위: \%]

\begin{tabular}{c|c|c|c|c|c|c|c}
\hline \multirow{2}{*}{\multicolumn{2}{c|}{ 구분 }} & \multicolumn{3}{|c|}{ 2019년 } & \multicolumn{3}{c}{ 2020년 } \\
\cline { 3 - 8 } \multicolumn{2}{c|}{} & $\begin{array}{c}\text { 자연 및 } \\
\text { 풍경감상 }\end{array}$ & 휴식/휴양 & 음식관광 & $\begin{array}{c}\text { 자연 및 } \\
\text { 풍경감상 }\end{array}$ & 휴식/휴양 & 음식관광 \\
\hline \multirow{2}{*}{ 전체 } & 71.4 & 56.9 & 52.8 & 78.9 & 59.5 & 55.9 \\
\hline \multirow{2}{*}{ 성별 } & 남성 & 69.9 & 57.2 & 51.6 & 78.3 & 59.2 & 53.7 \\
\cline { 2 - 8 } & 여성 & 73.0 & 56.7 & 54.1 & 79.6 & 59.8 & 58.2 \\
\hline \multirow{2}{*}{ 연령 } & 20대 이하 & 70.2 & 56.4 & 51.8 & 78.7 & 58.8 & 56.2 \\
\cline { 2 - 8 } & 30대 이상 & 74.3 & 58.2 & 55.2 & 79.5 & 61.0 & 55.3 \\
\hline \multirow{4}{*}{ 직업 } & 경제활동자 & 72.5 & 58.6 & 54.5 & 80.5 & 60.8 & 56.9 \\
\cline { 2 - 8 } & 학생 & 67.0 & 49.7 & 48.3 & 75.0 & 56.0 & 54.3 \\
\cline { 2 - 8 } & 전업주부 & 78.4 & 53.5 & 53.6 & 74.8 & 51.8 & 52.6 \\
\cline { 2 - 8 } & 무직 & 70.3 & 68.4 & 45.7 & 73.0 & 56.8 & 47.3 \\
\hline
\end{tabular}


〈표 계속)

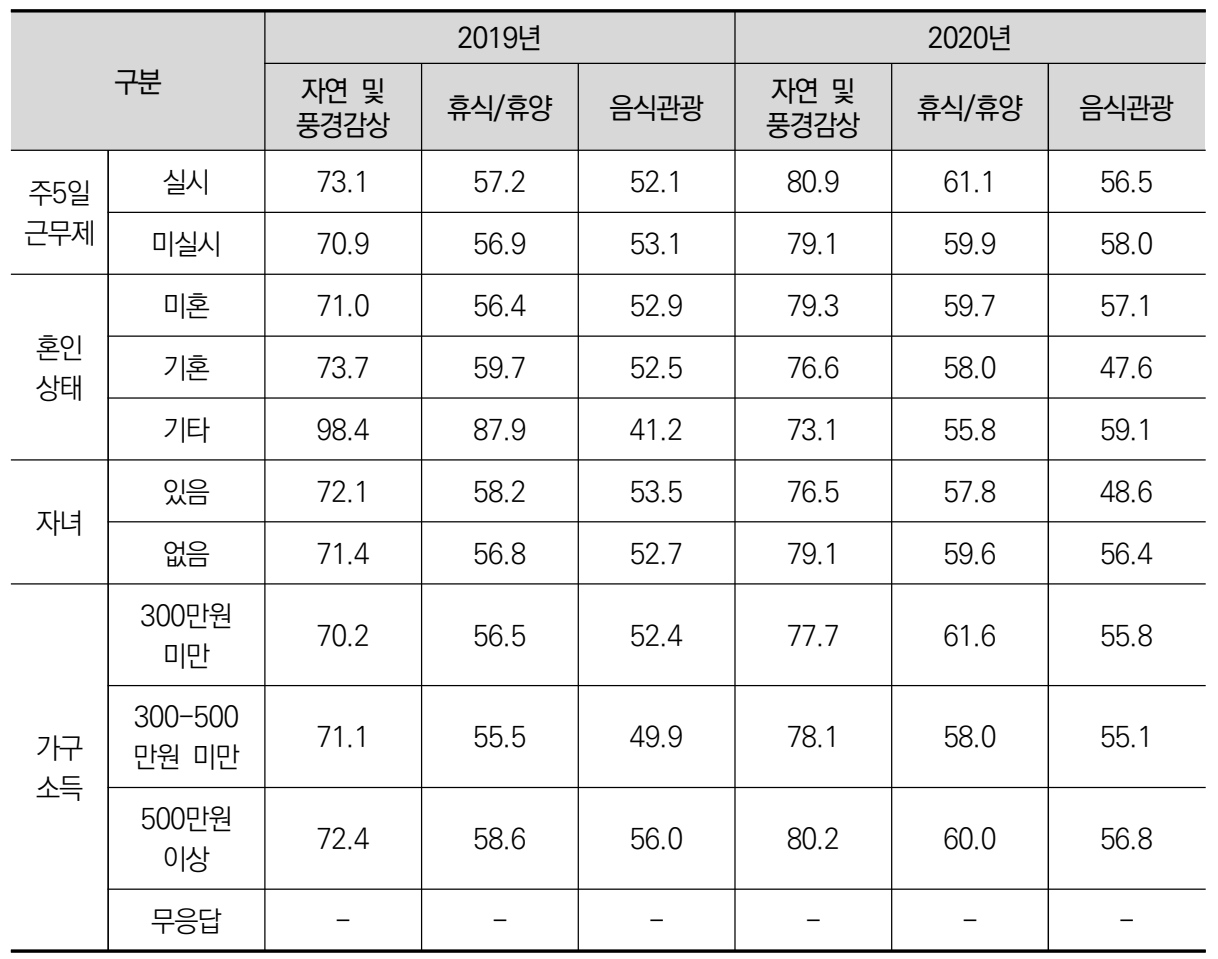

\section{7) 주요 이동 수단}

2020년 기준 청년층의 국내여행 시 주요 이동 수단은 '자가용(75.9\%)'으로 전체 국민 과 동일하게 청년층 또한 대부분 자가용을 이용하고 있으나, 상대적으로 '고속/시외/시 내버스(9.0\%)', '지하철(5.8\%)'등 대중교통에 대한 이용 비율이 높은 것으로 나타났다.

'자가용'의 이용은 30대 이상(86.2\%), 경제활동자(81.9\%), 전업주부(90.6\%), 기혼 (92.3\%), 자녀동반 가구(94.2\%) 등에서 높으며, 학생, 무직자, 미혼 등에서 상대적으로 대중교통 이용률이 높은 것으로 나타났다. 그러나 2020년에는 학생과 미혼 청년층에서 도 2019년 대비 자가용 이용이 크게 증가한 것으로 확인되었다. 
〈표 3-31〉 주요 이동 수단(상위 10개 항목)

[1순위 기준, 단위: \%]

\begin{tabular}{c|c|c|c|c}
\hline \multirow{2}{*}{ 구분 } & \multicolumn{2}{|c|}{ 2019년 } & \multicolumn{2}{c}{ 2020년 } \\
\cline { 2 - 5 } & 전체 & 청년층 & 전체 & 청년층 \\
\hline 자가용 & 77.0 & 68.8 & 84.8 & 75.9 \\
\hline 고속/시외/시내 버스 & 5.6 & 10.8 & 4.5 & 9.0 \\
\hline 지하철 & 2.6 & 4.8 & 3.2 & 5.8 \\
\hline 항공기 & 3.2 & 3.7 & 2.7 & 2.3 \\
\hline 철도 & 4.6 & 7.5 & 1.9 & 3.6 \\
\hline 차량 대여/렌트 & 1.3 & 2.0 & 1.3 & 2.2 \\
\hline 전세/관광버스 & 4.3 & 1.1 & 0.7 & 0.4 \\
\hline 택시 & 0.5 & 0.8 & 0.3 & 0.5 \\
\hline 선박/해상 교통 & 0.5 & 0.4 & 0.2 & 0.2 \\
\hline 자전거 & 0.1 & 0.1 & 0.1 & 0.1 \\
\hline
\end{tabular}

〈표 3-32〉 청년층 특성별 주요 이동 수단(상위 3개 항목)

\begin{tabular}{|c|c|c|c|c|c|c|c|}
\hline & \multirow[b]{2}{*}{ 구분 } & \multicolumn{3}{|c|}{ 2019년 } & \multicolumn{3}{|c|}{ 2020년 } \\
\hline & & 자가용 & $\begin{array}{l}\text { 고속/시외/ } \\
\text { 시내버스 }\end{array}$ & 철도 & 자가용 & $\begin{array}{l}\text { 고속/시외/ } \\
\text { 시내버스 }\end{array}$ & 지하철 \\
\hline \multicolumn{2}{|r|}{ 전체 } & 68.8 & 10.8 & 7.5 & 75.9 & 9.0 & 5.8 \\
\hline \multirow{2}{*}{ 성별 } & 남성 & 70.4 & 9.8 & 8.0 & 75.7 & 8.9 & 6.2 \\
\hline & 여성 & 67.1 & 11.7 & 6.9 & 76.1 & 9.1 & 5.4 \\
\hline \multirow{2}{*}{ 연령 } & 20대 이하 & 61.6 & 14.1 & 9.2 & 71.4 & 11.8 & 7.1 \\
\hline & 30대 이상 & 85.1 & 3.1 & 3.5 & 86.2 & 2.6 & 2.9 \\
\hline \multirow{4}{*}{ 직업 } & 경제활동자 & 74.8 & 6.8 & 6.2 & 81.9 & 5.4 & 4.2 \\
\hline & 학생 & 46.9 & 24.6 & 11.8 & 55.6 & 21.3 & 11.2 \\
\hline & 전업주부 & 89.3 & 0.8 & 2.7 & 90.6 & 1.5 & 1.1 \\
\hline & 무직 & 59.3 & 16.5 & 10.5 & 62.9 & 15.4 & 10.6 \\
\hline \multirow{2}{*}{$\begin{array}{l}\text { 주5일 } \\
\text { 근무제 }\end{array}$} & 실시 & 81.7 & 5.5 & 4.7 & 83.2 & 4.1 & 4.2 \\
\hline & 미실시 & 64.4 & 12.5 & 8.4 & 77.9 & 9.5 & 4.3 \\
\hline \multirow{3}{*}{$\begin{array}{l}\text { 혼인 } \\
\text { 상태 }\end{array}$} & 미혼 & 65.1 & 12.4 & 8.6 & 73.5 & 10.1 & 6.5 \\
\hline & 기혼 & 89.7 & 1.4 & 1.4 & 92.3 & 0.9 & 1.4 \\
\hline & 기타 & 70.9 & 5.0 & - & 100.0 & - & - \\
\hline \multirow{2}{*}{ 자녀 } & 있음 & 90.4 & 1.6 & 1.6 & 94.2 & 0.4 & 0.9 \\
\hline & 없음 & 66.5 & 11.7 & 8.1 & 74.7 & 9.6 & 6.2 \\
\hline \multirow{4}{*}{$\begin{array}{l}\text { 가구 } \\
\text { 소득 }\end{array}$} & 300만원 미만 & 72.9 & 11.5 & 6.4 & 74.3 & 9.0 & 6.4 \\
\hline & $\begin{array}{c}\text { 300-500만원 } \\
\text { 미만 }\end{array}$ & 66.9 & 12.6 & 7.1 & 75.0 & 10.6 & 6.4 \\
\hline & 500만원 이상 & 68.8 & 8.6 & 8.4 & 77.5 & 7.4 & 5.1 \\
\hline & 무응답 & - & - & - & - & - & - \\
\hline
\end{tabular}




\section{8) 여행 평가}

2020년 100점 기준 청년층의 전반적 만족도는 80.1점, 재방문 의향은 76.3 점, 타인 추천 의향은 74.3점으로 나타났다. 청년층의 국내여행 평가는 전체 국민 대비 큰 차이는 없으며, 타인 추천 의향 외에는 2019년 대비 상승하였으나, 변동 폭 자체는 크지 않은 것으로 조사되었다.

〈표 3-33〉 여행 평가

[100점 만점 기준, 단위: 점]

\begin{tabular}{c|c|c|c|c}
\hline \multirow{2}{*}{ 구분 } & \multicolumn{2}{|c|}{2019 년 } & \multicolumn{2}{c}{2020 년 } \\
\cline { 2 - 5 } & 전체 & 청년층 & 전체 & 청년층 \\
\hline 전반적 만족도 & 78.9 & 79.0 & 79.8 & 80.1 \\
\hline 재방문 의향 & 75.5 & 75.6 & 76.2 & 76.3 \\
\hline 타인 추천 의향 & 74.3 & 74.3 & 74.2 & 74.3 \\
\hline
\end{tabular}

〈표 3-34〉 청년층 특성별 여행 평가

\begin{tabular}{|c|c|c|c|c|c|c|c|}
\hline & \multirow[b]{2}{*}{ 구분 } & \multicolumn{3}{|c|}{ 2019년 } & \multicolumn{3}{|c|}{ 2020년 } \\
\hline & & $\begin{array}{l}\text { 전반적 } \\
\text { 만족도 }\end{array}$ & 재방문 의향 & $\begin{array}{c}\text { 타인 추천 의 } \\
\text { 향 }\end{array}$ & $\begin{array}{l}\text { 전반적 } \\
\text { 만족도 }\end{array}$ & 재방문 의향 & $\begin{array}{c}\text { 타인 추천 의 } \\
\text { 향 }\end{array}$ \\
\hline \multicolumn{2}{|r|}{ 전체 } & 79.0 & 75.6 & 74.3 & 80.1 & 76.3 & 74.3 \\
\hline \multirow{2}{*}{ 성별 } & 남성 & 78.5 & 75.2 & 73.6 & 79.7 & 76.0 & 74.1 \\
\hline & 여성 & 79.4 & 75.9 & 74.9 & 80.5 & 76.6 & 74.5 \\
\hline \multirow{2}{*}{ 연령 } & 20대 이하 & 79.0 & 75.5 & 74.2 & 80.3 & 76.5 & 74.5 \\
\hline & 30대 이상 & 78.9 & 75.8 & 74.4 & 79.6 & 75.8 & 73.8 \\
\hline \multirow{4}{*}{ 직업 } & 경제활동자 & 78.9 & 75.8 & 74.4 & 80.3 & 76.5 & 74.3 \\
\hline & 학생 & 79.0 & 75.0 & 73.7 & 79.3 & 75.5 & 74.5 \\
\hline & 전업주부 & 79.5 & 77.2 & 76.0 & 79.0 & 78.1 & 76.8 \\
\hline & 무직 & 78.9 & 73.6 & 72.0 & 80.5 & 75.6 & 73.3 \\
\hline \multirow{2}{*}{$\begin{array}{l}\text { 주5일 } \\
\text { 근무제 }\end{array}$} & 실시 & 79.0 & 75.6 & 74.1 & 80.4 & 76.5 & 74.5 \\
\hline & 미실시 & 78.8 & 76.2 & 75.3 & 80.2 & 76.3 & 73.5 \\
\hline \multirow{3}{*}{$\begin{array}{l}\text { 혼인 } \\
\text { 상태 }\end{array}$} & 미혼 & 79.0 & 75.5 & 74.1 & 80.1 & 76.2 & 74.2 \\
\hline & 기혼 & 79.1 & 76.0 & 74.9 & 80.4 & 76.6 & 74.8 \\
\hline & 기타 & 72.3 & 71.0 & 69.9 & 78.9 & 78.0 & 77.1 \\
\hline \multirow{2}{*}{ 자녀 } & 있음 & 78.9 & 76.2 & 75.5 & 80.3 & 77.1 & 75.2 \\
\hline & 없음 & 79.0 & 75.5 & 74.1 & 80.1 & 76.2 & 74.3 \\
\hline \multirow{4}{*}{$\begin{array}{l}\text { 가구 } \\
\text { 소득 }\end{array}$} & 300만원 미만 & 77.2 & 74.0 & 72.9 & 79.6 & 75.4 & 73.1 \\
\hline & $\begin{array}{c}\text { 300-500만원 } \\
\text { 미만 }\end{array}$ & 78.9 & 75.5 & 74.2 & 80.0 & 76.0 & 74.3 \\
\hline & 500만원 이상 & 79.9 & 76.4 & 74.9 & 80.3 & 76.8 & 74.8 \\
\hline & 무응답 & - & - & - & - & - & - \\
\hline
\end{tabular}




\section{9) 여행사 상품 구매 여부 및 구매 시기}

2020 년 기준 청년층의 여행사 상품 구매 비율은 $1.2 \%$ 에 불과하며, 전년 대비 소폭 감소하여, 전체 국민과 비슷한 수준을 보이고 있다. 구매 시기의 경우, ' 1 개월 전에' 예 약한 비율이 2019년 대비 크게 증가한 반면, '2-3주 전'에 예약한 비율은 감소하였다.

〈표 3-35〉 여행사 상품 구매 여부 및 구매 시기

[단위: \%]

\begin{tabular}{|c|c|c|c|c|c|}
\hline & \multirow{2}{*}{ 구분 } & \multicolumn{2}{|c|}{ 2019년 } & \multicolumn{2}{|c|}{ 2020년 } \\
\hline & & 전체 & 청년층 & 전체 & 청년층 \\
\hline \multicolumn{2}{|c|}{ 여행사 상품 구매 } & 4.0 & 3.7 & 1.3 & 1.2 \\
\hline \multirow{9}{*}{$\begin{array}{l}\text { 구매 } \\
\text { 시기 }\end{array}$} & 6개월 이상 전에 & 1.5 & 0.2 & 1.1 & - \\
\hline & 4 6개월 전에 & 5.7 & 1.7 & 5.6 & 2.5 \\
\hline & 2 3개월 전에 & 22.2 & 18.5 & 20.2 & 17.7 \\
\hline & 1개월 전에 & 42.2 & 43.4 & 44.2 & 52.9 \\
\hline & 2-3주 전에 & 19.5 & 23.6 & 19.3 & 11.5 \\
\hline & 4-7일 전에 & 6.6 & 10.2 & 5.7 & 9.1 \\
\hline & 2-3일 전에 & 1.8 & 0.8 & 2.8 & 2.7 \\
\hline & 하루 전에 & 0.1 & 0.5 & 0.6 & 2.3 \\
\hline & 당일 & 0.4 & 1.3 & 0.4 & 1.4 \\
\hline
\end{tabular}

2020년 여행사 상품을 구매한 청년층 중 '부분 패키지’를 구매한 비율은 $86.6 \%$ 로 나 타났으며, '숙박시설(84.7\%)'에 대한 구매가 가장 많은 것으로 분석되었다. 전반적으로 2019년 대비 '부분 패키지' 구매 비율이 크게 증가했으며, 청년층은 전체 국민에 비해 세부 상품에 대한 예약률 역시 높은 것으로 보인다.

〈표 3-36〉 구매한 여행사 상품

[단위: \%]

\begin{tabular}{|c|c|c|c|c|}
\hline \multirow{2}{*}{ 구분 } & \multicolumn{2}{|c|}{ 2019년 } & \multicolumn{2}{|c|}{ 2020년 } \\
\hline & 전체 & 청년층 & 전체 & 청년층 \\
\hline 전체 패키지 & 51.4 & 26.1 & 34.1 & 13.4 \\
\hline 부분 패키지 & 48.6 & 73.9 & 65.9 & 86.6 \\
\hline 숙박시설 & 67.8 & 68.1 & 81.7 & 84.7 \\
\hline 교통 & 43.9 & 46.1 & 39.5 & 46.1 \\
\hline 차량임대 & 21.9 & 23.6 & 18.7 & 20.3 \\
\hline 레저시설 & 19.0 & 22.1 & 14.8 & 19.6 \\
\hline 기타 & 2.0 & 2.9 & - & - \\
\hline
\end{tabular}




\section{0) 여행 사전 예약}

2020년 청년층의 국내여행 사전 예약 비율은 36.6\%로 2019년 대비 5.9\%p 감소하 였으나, 전체 국민 의 $30.6 \%$ 대비 높은 수준을 유지하였다. '숙박시설(80.2\%)'에 대한 예약이 대부분을 차지하고 있으며, 전체 국민 대비 '교통수단(29.6\%)'에 대한 예약 비율 이 상대적으로 높았다. 가구 소득이 높을수록 사전 예약률 또한 높은 경향이 있으며, 자 녀가 있는 청년층의 경우, 사전 예약률이 2019년 대비 크게 감소하였다.

〈표 3-37〉 여행 사전 예약

[단위: \%]

\begin{tabular}{|c|c|c|c|c|c|}
\hline & \multirow{2}{*}{ 구분 } & \multicolumn{2}{|c|}{ 2019년 } & \multicolumn{2}{|c|}{ 2020년 } \\
\hline & & 전체 & 청년층 & 전체 & 청년층 \\
\hline \multicolumn{2}{|c|}{ 사전 예약 여부 } & 39.8 & 42.5 & 30.6 & 36.6 \\
\hline \multirow{8}{*}{$\begin{array}{l}\text { 예약 } \\
\text { 유형 }\end{array}$} & 숙박시설 & 78.4 & 77.3 & 81.4 & 80.2 \\
\hline & 교통수단 & 22.3 & 26.5 & 25.3 & 29.6 \\
\hline & 차량대여/렌트 & 8.8 & 9.5 & 11.9 & 11.4 \\
\hline & 레저시설 & 6.4 & 3.6 & 5.1 & 2.0 \\
\hline & 식당 & 8.1 & 11.1 & 5.0 & 4.2 \\
\hline & 관광명소 & 3.6 & 2.9 & 1.4 & 1.4 \\
\hline & 체험 프로그램 & 2.4 & 2.6 & 1.2 & 0.8 \\
\hline & 기타 & 1.0 & 1.1 & 0.4 & 0.2 \\
\hline
\end{tabular}

〈표 3-38〉 청년층 특성별 여행 사전 예약률

[단위: 명]

\begin{tabular}{|c|c|c|c|}
\hline \multicolumn{2}{|r|}{ 구분 } & 2019년 & 2020년 \\
\hline \multicolumn{2}{|r|}{ 전체 } & 42.5 & 36.6 \\
\hline \multirow{2}{*}{ 성별 } & 남성 & 43.0 & 36.4 \\
\hline & 여성 & 42.0 & 36.8 \\
\hline \multirow{2}{*}{ 연령 } & 20대 이하 & 42.5 & 37.8 \\
\hline & 30대 이상 & 42.4 & 33.9 \\
\hline \multirow{4}{*}{ 직업 } & 경제활동자 & 42.4 & 37.2 \\
\hline & 학생 & 43.4 & 34.9 \\
\hline & 전업주부 & 40.2 & 33.4 \\
\hline & 무직 & 39.9 & 36.4 \\
\hline \multirow{2}{*}{$\begin{array}{l}\text { 주5일 } \\
\text { 근무제 }\end{array}$} & 실시 & 41.1 & 36.3 \\
\hline & 미실시 & 45.6 & 40.0 \\
\hline \multirow{3}{*}{$\begin{array}{l}\text { 혼인 } \\
\text { 상태 }\end{array}$} & 미혼 & 43.4 & 37.7 \\
\hline & 기혼 & 37.1 & 28.0 \\
\hline & 기타 & 47.3 & 51.2 \\
\hline
\end{tabular}


〈표 계속)

\begin{tabular}{|c|c|c|c|}
\hline \multicolumn{2}{|r|}{ 구분 } & 2019년 & 2020년 \\
\hline \multirow{2}{*}{ 자녀 } & 있음 & 39.2 & 26.1 \\
\hline & 없음 & 42.8 & 37.3 \\
\hline \multirow{4}{*}{$\begin{array}{l}\text { 가구 } \\
\text { 소득 }\end{array}$} & 300만원 미만 & 39.4 & 33.6 \\
\hline & 300-500만원 미만 & 40.5 & 34.4 \\
\hline & 500만원 이상 & 46.0 & 39.9 \\
\hline & 무응답 & - & - \\
\hline
\end{tabular}

청년층 세분집단별 사전예약 항목을 살펴보면 ‘숙박시설’ 은 가구 소득이 높을수록 예 약률이 높은 반면, '교통수단'은 오히려 가구 소득이 낮을수록 예약 비율이 높은 경향이 나타났다.

〈표 3-39〉 청년층 특성별 사전 예약 항목(상위 3개 항목)

\begin{tabular}{|c|c|c|c|c|c|c|c|}
\hline & \multirow{2}{*}{ 구분 } & \multicolumn{3}{|c|}{ 2019년 } & \multicolumn{3}{|c|}{ 2020년 } \\
\hline & & 숙박시설 & 교통수단 & 레저시설 & 숙박시설 & 교통수단 & 차량대여/렌트 \\
\hline \multicolumn{2}{|r|}{ 전체 } & 77.3 & 26.5 & 11.1 & 80.2 & 29.6 & 11.4 \\
\hline \multirow{2}{*}{ 성별 } & 남성 & 76.8 & 24.2 & 13.1 & 79.1 & 26.5 & 11.1 \\
\hline & 여성 & 77.7 & 28.8 & 9.1 & 81.4 & 32.9 & 11.7 \\
\hline \multirow{2}{*}{ 연령 } & 20대 이하 & 75.4 & 29.3 & 11.5 & 77.8 & 31.0 & 10.8 \\
\hline & 30대 이상 & 81.6 & 20.0 & 10.3 & 86.2 & 26.3 & 13.0 \\
\hline \multirow{4}{*}{ 직업 } & 경제활동자 & 81.0 & 23.8 & 10.0 & 84.6 & 26.3 & 10.9 \\
\hline & 학생 & 64.8 & 34.3 & 14.6 & 64.8 & 41.5 & 12.1 \\
\hline & 전업주부 & 87.6 & 15.7 & 12.6 & 82.8 & 24.3 & 20.5 \\
\hline & 무직 & 71.9 & 39.9 & 10.9 & 72.1 & 36.2 & 12.1 \\
\hline \multirow{2}{*}{$\begin{array}{l}\text { 주5일 } \\
\text { 근무제 }\end{array}$} & 실시 & 80.6 & 25.4 & 10.8 & 85.2 & 26.3 & 12.1 \\
\hline & 미실시 & 81.8 & 20.5 & 8.4 & 82.9 & 26.4 & 7.6 \\
\hline \multirow{3}{*}{$\begin{array}{l}\text { 혼인 } \\
\text { 상태 }\end{array}$} & 미혼 & 76.2 & 28.5 & 11.2 & 79.3 & 30.7 & 11.3 \\
\hline & 기혼 & 83.9 & 12.6 & 10.7 & 88.6 & 18.3 & 12.9 \\
\hline & 기타 & 100.0 & 50.9 & - & 95.4 & 58.4 & - \\
\hline \multirow{2}{*}{ 자녀 } & 있음 & 83.2 & 11.4 & 13.0 & 87.1 & 17.5 & 15.0 \\
\hline & 없음 & 76.7 & 27.9 & 11.0 & 79.9 & 30.2 & 11.2 \\
\hline \multirow{4}{*}{$\begin{array}{l}\text { 가구 } \\
\text { 소득 }\end{array}$} & 300만원 미만 & 73.4 & 28.5 & 11.2 & 68.8 & 40.1 & 10.8 \\
\hline & 300-500만원 미만 & 74.7 & 27.8 & 10.6 & 80.8 & 28.4 & 11.0 \\
\hline & 500만원 이상 & 81.2 & 24.4 & 11.6 & 83.6 & 27.1 & 11.9 \\
\hline & 무응답 & - & - & - & - & - & - \\
\hline
\end{tabular}




\section{3. 소결}

본 절에서는 지난 2개년(2019년, 2020년)간의 국민여행조사 원자료를 분석하여 청년 층의 국내여행 실태를 파악하고, 청년층의 국내여행 특성을 심층적으로 분석하기 위한 기초자료를 생산하고자 하였다.

국민여행조사 분석 결과 청년층은 전체 국민과 비교하여 여행 총량 및 행태 측면에서 유의미한 차이를 나타내고 있으며, 특히 정보획득 경로, 이동 수단, 여행지 활동, 숙박시 설 등에 있어서 전체 국민과 구분되는 특성을 나타내었다. 코로나19로 인한 국내여행 영향에 있어서 전체 국민과 구분되는 차이가 드러나기도 하였으며, 일부 국내여행 총량 및 여행 행태 항목에 있어서는 청년층 내 세분집단별 차이 또한 관찰되었다. 국민여행조 사 원자료 분석을 통해 나타난 청년층의 국내여행 특성은 다음과 같다.

\section{가. 여행 총량}

2020년 기준 청년층의 국내여행 경험률(91.6\%)은 전체 국민의 여행 경험률(86.4\%) 대비 높은 것으로 나타났으며, 1 인 평균 국내여행 횟수(6.06회), 1 인 평균 국내여행 일 수(9.32일), 1 인 평균 여행 지출액(68만 6,000 원) 등 또한 전체 국민 대비 높은 것으로 확인되었다. 특히, 2020년에는 코로나19의 확산으로 인한 여행심리의 위축과 사회적 거리두기 조치의 시행 등 전반적인 국내여행 활동이 제한된 상황 하에서 전반적으로 여 행총량이 감소하는 경향을 나타냈으나 청년층은 전체 국민과 비교해 여행총량의 감소폭 이 상대적으로 작은 것으로 확인되었다. 
〈표 3-40〉 청년층 국내여행 총량 비교

[단위: \%, 천 회, 천 일, 천 원]

\begin{tabular}{c|c|c|c|c}
\hline \multirow{2}{*}{ 구분 } & \multicolumn{2}{|c|}{ 2019년 } & \multicolumn{2}{c}{2020 년 } \\
\cline { 2 - 5 } 여행 경험률 & 전체 & 청년 & 전체 & 청년 \\
\hline 1인 평균 여행 횟수 & 7.41 & 91.2 & $\begin{array}{c}86.4 \\
(\triangle 6.0 \% \mathrm{p})\end{array}$ & $\begin{array}{c}91.6 \\
(0.4 \% \mathrm{p})\end{array}$ \\
\hline 1인 평균 여행 일수 & 12.94 & 14.17 & $\begin{array}{c}4.95 \\
(\triangle 35.0 \%)\end{array}$ & $\begin{array}{c}6.06 \\
(\triangle 26.4 \%)\end{array}$ \\
\hline 1인 평균 여행지 지출 & 976 & 1,118 & $\begin{array}{c}530.9 \%) \\
(\triangle 45.7 \%)\end{array}$ & $\begin{array}{c}6.32 \\
(\triangle 34.2 \%)\end{array}$ \\
\hline
\end{tabular}

청년층 내 세분집단별 차이를 살펴보면 2019년에는 여성, 30대 이상, 전업주부, 주5 일 근무제 시행 사업장의 직장인, 기혼 가구 및 자녀동반 가구 등의 국내여행 활동이 상대적으로 활발한 것으로 나타났으나, 코로나 19 가 확산된 2020년에는 전업주부, 기혼 가구 및 자녀동반 가구 등의 국내여행 활동이 큰 폭으로 위축되었으며, 무직자 계층의 경우 기존보다 국내여행 향유 경험이 크게 줄어들어 타 집단과의 격차가 보다 확대된 것으로 확인되었다.

\section{나. 여행 행태}

청년층의 주요 여행 행태는 전체 국민과 전반적으로 유사한 것으로 나타났으나 여행 정보 획득 경로, 동반객 수 및 유형, 여행지 활동, 이동 수단, 여행상품의 구매 행동 등에 서 상대적인 차이가 관찰되었다. 청년층에게서 특징적으로 드러나는 여행정보 획득 경로 는 '인터넷 사이트/모바일 앱'으로 포털사이트, SNS, 동영상 사이트에 대한 선호가 높은 것으로 나타났다.

청년층의 국내여행 동반자 수는 전체 국민 대비 다소 적은 것으로 나타났으며, '친구/ 연인'과 동반하는 경우가 대다수를 차지하였다. 다만 20대 이하 및 미혼인 경우 '친구/ 연인' 비율이 높은 반면, 전업주부와 기혼 가구 및 자녀동반 가구에서는 반대로 '가족'의 비율이 대부분을 차지하였다.

청년층의 주된 여행지 활동은 자연 및 풍경 감상으로 조사되어 여행지 활동면에서 전 
체 국민과 큰 차이를 보이지는 않았으나, '시티투어', '테마파크, 놀이시설, 동/식물원 방 문' 등 체험활동에 참여하는 비율이 상대적으로 높은 것으로 드러났다.

주요 이동 수단으로는 전체 국민과 동일하게 청년층 또한 대부분 자가용을 이용하고 있으나, 상대적으로 '고속/시외/시내버스', '지하철'등 대중교통에 대한 이용 비율이 높 았는데, 학생, 무직자, 미혼 등에서 상대적으로 대중교통 이용률이 높은 것으로 확인되 었다. 그러나 2020년에는 학생과 미혼 청년층에서도 2019년 대비 자가용 이용이 크게 증가한 것으로 확인되었는데 이는 코로나19 확산으로 안전한 여행에 대한 욕구가 증대 된 영향으로 이해할 수 있다.

청년층은 여행상품 이용 시 전체 국민대비 높은 사전 예약률을 보였으며 '숙박시설'에 대한 예약이 대부분을 차지하였다. 


\section{제2절 청년관광 표적집단면접(FGI) 조사}

\section{1. 조사 개요}

\section{가. 조사 목적}

본 절에는 국민여행조사 원자료 분석 결과를 바탕으로 청년층 내면의 국내관광 인식, 국내관광 행태 등을 파악하고 '청년층 국내관광 특성 심층 조사'를 위한 구조화된 설문 지를 도출하기 위하여 청년층을 대상으로 표적집단면접을 실시하고 의견을 청취하였다. 특히 제1절의 국민여행조사 원자료 분석결과에 따르면 청년층은 동일 연령집단 내에서 학생과 직장인, 미혼자 및 기혼자, 자녀 동반가구 등 다양한 생애주기의 세분집단으로 구분이 가능하며, 국내관광에 대한 인식과 행태에 있어서도 일부 차이가 관찰되었다.

따라서 본 절에서는 청년층의 전반적인 국내관광 인식과 관광행태를 파악하는 것 뿐 만 아니라 세분집단별 특성을 도출하는 데에 주안점을 두고 청년관광 표적집단면접을 수행하였다.

\section{나. 조사 설계}

표적집단면접은 ‘국내관광 인식 및 행태 파악'이라는 조사 목적을 달성하기 위하여 최 근 3년간 반기 1회 이상 국내여행에 참여한 경험이 있는 만 19-34세 청년층을 대상으로 실시하였으며, 경제활동 여부, 결혼 여부, 자녀 유무 등 청년층을 세분할 수 있는 주요 인구통계적 요인 고려하여 5명씩 2개 그룹으로 구분 후 면접을 실시하였다.

또한, 원활한 면접의 진행을 위해 피면접자의 국내여행 경험, 코로나 19 이후의 국내 여행 행태 변화, 여행 제약 및 촉진 요인, 정부 지원 시책 이용 경험 등에 대한 질문지를 사전에 배포하여 본 면접의 참고자료로 활용하였다. 면접은 연구진이 진행자로 참여하여 사전에 배포된 질문지의 응답내용을 중심으로 진행하였으며 개별 그룹별 두 시간의 시 
간을 할애하여 청년층의 국내여행 인식 및 경험을 다각도로 살펴보고자 하였다.

〈표 3-41〉 표적집단면접 조사 설계

\begin{tabular}{|c|c|c|}
\hline 구분 & 그룹 1 & 그룹 2 \\
\hline 조사대상 & $\begin{array}{l}\text { - 여행 경험: 반기 1회 이상 국내 숙박여행 경 } \\
\text { 험자(최근 3년) } \\
\text { - 연령: 만 19-34세 청년층 } \\
\text { - 결혼 여부: 미혼 }\end{array}$ & $\begin{array}{l}\text { - 여행 경험: 반기 1회 이상 국내 숙박여행 경 } \\
\text { 험자(최근 3년) } \\
\text { - 연령: 만 19-34세 청년층 } \\
\text { - 결혼 여부: 기혼 }\end{array}$ \\
\hline 표본배분 & $\begin{array}{l}\text { - 경제활동 여부: 직장인 3명 / 대학생 및 대 } \\
\text { 학원생 } 2 \text { 명 }\end{array}$ & - 자녀 유무: 자녀 2명 / 무자녀 3명 \\
\hline 표 본 수 & 5 명 & 5명 \\
\hline
\end{tabular}

\section{다. 조사 내용}

면접의 주요 질의 항목은 청년층의 국내여행 행태, 국내 여행에 대한 인식 및 선호, 여행 제약 및 촉진 요인, 정부의 국내여행 지원 프로그램에 대한 인식 및 경험 등으로 구성 되었다. 면접 조사의 주요 항목은 관광교통패스 도입 방안 연구(한국관광공사, 2018), 국민의 해외여행 동향 분석(조아라 - 김형종, 2019), 국민여행조사(문화체육관광 부, 2020) 등 기존 유사 선행연구의 설문조사 문항을 참고하였으며, 연구진의 검토를 거쳐 본 연구의 특성에 맞도록 재구성 하였다(〈표 3-42〉 참조).

〈표 3-42〉 표적집단면접 조사 설계

\begin{tabular}{|c|c|c|}
\hline 구분 & \multicolumn{2}{|c|}{ 주요 내용 } \\
\hline 청년층 국내여행 실태 & $\begin{array}{l}\text { - 연간 여행 총량 } \\
\text { - 연중 여행시기 } \\
\text { - 여행 목적 } \\
\text { - 여행 동반자 } \\
\text { - 최근 여행 방문지 (선택이유) }\end{array}$ & $\begin{array}{l}\text { - 주요 이동수단 (이용이유) } \\
\text { - 주요 숙박시설 (이용이유) } \\
\text { - 여행지 주요 활동 } \\
\text { - 여행 지출액 } \\
\text { - 코로나 } 19 \text { 이후 여행 행태 변화 }\end{array}$ \\
\hline 청년층의 여행 인식 및 선호 & - 청년층에게 있어서 여행의 의미 & - 국내여행 및 해외여행에 대한 선호 \\
\hline 가장 기억에 남는 국내여행 경험 & - 가장 기억에 남는 국내 여행지 & - 여행목적, 동반자, 주요 활동 등 \\
\hline 국내여행 제약 및 촉진 요인 & - 국내여행 제약 요인 (촉진 요인) & - 국내여행 의사 결정 시 중요 요인 \\
\hline $\begin{array}{c}\text { 정부(또는 민간)의 국내여행 지원 } \\
\text { 프로그램 인식 및 경험 }\end{array}$ & $\begin{array}{l}\text { - 국내여행 지원 프로그램 인지도 } \\
\text { - 국내여행 지원프로그램 참여 경험 } \\
\text { 및 이유 }\end{array}$ & $\begin{array}{l}\text { - 국내여행 지원 프로그램에 참여하 } \\
\text { 지 않은 이유 } \\
\text { - 청년층 국내여행 활성화를 위해 필 } \\
\text { 요한 정부 지원 }\end{array}$ \\
\hline
\end{tabular}




\section{2. 조사 결과}

본 절에서는 청년층의 국내관광 인식 및 행태적 특성을 알아보기 위해 표적집단면접 을 수행하였다. 표적집단면접에서는 청년층의 국내여행 실태를 비롯하여 여행인식 및 선 호, 기억에 남는 국내여행 경험, 국내여행 제약 및 촉진요인, 국내여행 지원 프로그램 인식 및 경험 등이 폭넓게 논의되었다. 다만 자연스러운 분위기에서 응답자의 경험을 이끌어내기 위하여 조사 항목을 분절적으로 질의하기 보다는 응답자가 최초 질문과 관 련되는 내용을 충분히 응답할 수 있도록 진행하였다. 따라서 본 절의 인터뷰 결과의 기 술에 있어서도 조사 항목의 구분 보다는 청년층 관광의 특징을 중심으로 기술하였다.

\section{가. 여행정보 획득 경로}

청년층은 여행의사를 결정하거나 여행정보를 획득할 때 소셜미디어 및 인터넷 정보를 (네이버 블로그, 인스타그램, 구글, 유튜브 등)을 적극적으로 활용하고 있는 것으로 나타 났다. 특히 청년층은 소셜미디어 및 인터넷 정보 활용시 다양한 매체를 동시에 활용하고 있으며, 획득한 각기 다른 형태와 내용의 정보를 다각도로 검토하여 여행과정에 활용한 다는 점에서 다른 연령집단과 비교해 눈에 띄는 차이점을 보인다.

한편 일부 청년층의 경우 인터넷 정보를 일부 활용하기도 하나 과거의 경험이나, 주변 인으로부터 획득한 정보를 여행의사 결정 및 여행 과정에 활용하는 것으로 확인되었다.

- 가끔 인스타그램 피드에 여행지 이미지가 올라오는데, 예쁘고 가보고 싶다는 생각이 들면 어디인지 파악 한 후에 자세한 정보는 네이버 블로그를 찾아보고, 여행지에서 거기서 방문할 맛집은 구글 평점을 참고하 는 방식으로 여행 정보를 획득 (오혜 $\bigcirc$ )

- "인스타 보다가 누군가 갔는데 좋아 보이면, 혹은 알고리즘에 따라서 좋은 곳, 어디 추천리스트 나오는 게 있어요. 그런 걸 보고 네이버에 찾아보고, 유튜브 찾아보고 좋아 보이면 다음에 여기 가야 되겠다," (변동)

- “인스타그램에서 이미지를 추출 해서 괜찮다 싶은 관광지를 유튜브에서 실제 영상 찍은 걸 봐요. 이 정도면 가볼 만하겠다," (장윤 $\bigcirc$ )

-“구글이랑 네이버랑 인스타랑 동시에 다 검색해 봐요. 리뷰 위주로 검색을 해요. 설명이 중요한 게 아니 라 사람들 리뷰로 평점 낮은 순으로 해서. 높은 건 광고일 확률이 높다고 해서 역으로." (김영릭)

- 인스타그램은 친숙하지 않아서 네이버 블로그를 검색하게 되고, 무계획으로 가는 경우가 많아서, 현지인 또는 지인으로부터 여행과 관련된 정보를 획득함 (오종ᄋ, 마유)

-“SNS 많이 이용하긴 하는데 같은 관광지라고 1년 전과 5년 전이 다른 경우가 많아서, 주변 같은 또래 니까 여행 다녀온 직장 동료나 친구들 중에 어디가 좋았나 물어보고, 몇 개 리스트 한 다음에 와이프랑 상의해서" (채경 $\bigcirc)$ 


\section{나. 영유아동반 여행 경험}

청년층 내에서도 영유아 자녀를 동반한 가구와 이에 해당하지 않는 가구 간 여행행태 및 추구편익에 있어서 의미 있는 차이가 발견되었다. 특히, 영유아를 동반하고 여행하는 가구의 경우 숙박시설 선택 시 자녀를 중심으로 의사결정을 하고 있었다. 예를 들어 펜 션과 같이 자녀가 뛰어 놀 수 있는 넒은 공간의 숙소를 선호하거나 자녀의 안전을 위해 낙상 위험이 없는 한옥 유형의 숙소를 선택하였다.

또한, 공공화장실 등에 유아용가 이용할 수 있는 위생시설 비치를 희망하였으며, 자녀 가 즐길 수 있는 다양한 교육 콘텐츠의 필요성을 느끼고 있었다.

- "숙소를 알아보고 가장 선호하는 건 온돌방(안전문제)이긴 하거든요. 침대가 없는. 한옥은 너무 좋고.... 근처에 구경거리가 하나만 있어도, 아이를 동반하고는 그것도 즐기기가 쉽지 않거든요." (이진) . "펜션. 왜냐하면 공간이 넓은 데 선호해요. 호텔은 아무래도 사이즈가 크기가 쉽지 않잖아요. 실제 생활하 는 공간보다는. 애들과 갈 때는 펜션 위주로 가는 거고," (김영이)

- "공공 화장실을 가면 기저귀를 가는 게 너무 갓난애기용 가는 게 있어요(유아용 제품X). 막상 그렇게 갓난 애기를 데리고 안 가거든요... 화장실 문제가 조금, 기저귀를 안 뗀 애를 데리기 다니기 힘들었고, 기저귀 를 막 뗀 아이도 있는데 유아용 변기가 있으면 좋고, 없으면 커버라도 있으면 좋거든요.."(이진)

- “교육적인 것... 5세 이하, 한글을 아직까지 모르지만 영상적이거나 그런 부분에 대해서 노출되는 게 있으 면 좋겠는 거예요. 저도 간단하게 애기만 해 주는 거고, 그냥 구경하는 걸로 끝나는 것 같더라고요. 유적 지나 관광지, 역사적인 곳은. 특히 5 세 이하는 그런 것 같아요." (김영으)

- "애들을 데리고 가는 관광지가 어느 정도 한정돼 있을 것 같거든요. 어릴 때 다녔던 여행의 기억이 아이들 한테 진짜 중요한데, 그때 뮌가 잘 교육이 된다고 한다면 큰 도움이 될 것 같아요." (이진O)

\section{다. 코로나19로 인한 여행 행태 변화}

코로나19의 확산은 청년층의 관광 행태에 상당한 변화를 야기하였는데 그 중에서도 국내여행의 증가, 다중이용 시설에 대한 회피, 위생과 방역 수칙 준수 여부 고려, 비대면 수업 방식을 이용한 여행 시간의 증가 등이 두드러지게 나타났다.

청년층은 코로나 19 의 확산으로 인해 입국제한 조치 등 해외여행에 대한 제약이 발생 하면서 국내여행 중심의 관광 활동을 이어나갔다. 또한 감염병에 대한 우려에 따라 다중 이용 시설을 회피하고자 하는 노력을 기울였는데, 이는 관광지 활동(자연경관 감상), 이 동수단(자가용), 숙박시설(위생 및 방역수칙 준수), 여행시간(이른 아침) 등에 대한 행태 변화를 통해 관찰된다.

특히, 숙박시설 이용시에는 저렴한 가격보다는 위생적인 환경과 방역지침 준수 여부 
를 우선적으로 고려하고 있으며, 숙박시설 예약 사이트를 통해 관련 정보를 철저히 검증 하고 있다. 학생들의 경우 비대면 수업의 도입으로 일상활동 중 장소에 대한 제약이 완 화됨에 따라 여행 할 수 있는 시간이 증가한 것으로 나타났다.

- 기존에 해외여행을 주로 갔고 유명 관광지, 유적지 등을 주로 방문했었는데, 코로나19로 인해 국내여행을 자주하게 되었고 관광객으로 붐비지 않는 자연경관 위주의 여행으로 변화 (오혜 $\bigcirc$, 변동 $\bigcirc$, 채경 $\bigcirc$, 김영 )

- 온라인 수업 등 많은 활동이 비대면 방식으로 전환되면서 여행을 할 수 있는 시간이 증가하였고, 여행지에 서 스마트기기를 이용하여 온라인 수업에 참여함 (장윤 $\bigcirc$ )

- 기차, 비행기 등과 같이 많은 사람들이 이용하는 교통수단을 회피하고, 자가용을 이용하여 여행할 수 있는 장소를 선호함 (변동)

- 5세, 3세 자녀가 있어서 국내여행을 자주하는 편인데 숙박여행을 할 경우 가족만 안전하게 휴식할 수 있는 공간이 있기 때문에 코로나19 확산 후에도 숙박여행 빈도는 유지하고 있고, 오히려 당일 여행 시 사람이 없는 아침 시간에 출발하여 오후에 귀가하는 방식으로 변화 (이진이

- 이전에는 숙박비 부담으로 저렴한 숙소를 주로 이용했는데, 코로나19 확산 이후에는 예약 사이트에 "방역 철저, 소독을 잘 하고 있다”는 문구가 표시되어 있으면 우선적으로 고려하고 돈이 더 들더라도 위생적이 고 방역수칙을 준수하는 숙소를 이용함 (오종 $\mathrm{O}$, 김영리)

\section{라. 청년층의 국내여행 인식 및 선호}

표적집단면접에 참여한 대부분의 청년은 대체로 국내여행보다는 해외여행을 선호하 는 것으로 응답하였다. 그러나 청년층 내에서도 가구형태(영유아 자녀의 유무)에 따라 응답이 상이하게 나타났다.

먼저 해외여행을 선호하는 이유로는 국내여행에 비해 일상으로부터의 해방감 만끽할 수 있다는 점과 국내여행 대비 경쟁력(가성비/가심비) 있는 가격을 첫 손에 꼽았다. 특 히, 청년들은 국내 물가가 비싸다고 느끼고 있었으며, 동일한 활동과 프로그램을 진행하 는 경우 항공기를 이용하여 해외여행을 떠나는 것에 큰 부담을 느끼지 않는 것으로 나타 났다. 이 외에도 일부 청년들은 국내여행은 지금이 아니더라도 살아가면서 언제든지 떠 날 수 있다는 인식을 가지고 있었다.

반면에 영유아 자녀를 동반하고 여행하는 가구에서는 아이를 동반한 채 비행기를 타 고 장시간 여행을 하는 것에 대한 부담으로 인해 상대적으로 국내여행을 선호하는 비중 이 높은 것으로 나타났다. 
- 여행이라는 건 해방감을 주는 게 제일 중요한데 국내여행을 하다 보면 일상(연락, 언어, 음식 등)과 멀어지 는 건 한계, 좀 더 여행이라는 맛을 느끼기 위해서는 해외여행을 함 (변동ㅇ, 오혜 $\bigcirc$ )

- 국내로 갈 거면 가격적인 부분에서 메리트가 있어야 되는데, 생각보다 국내여행을 하는 거랑 외국에서 여행을 하는 거랑 비용 차이가 크지 않아요. 같은 활동, 프로그램이더라도 우리나라에서 할 바에는 외국에 나가서 하자는 생각을 갖고 있음 (장윤 $\bigcirc$, 오종 $\bigcirc$ )

- 국내여행은 계속 한국에 살 거니까 언젠가 갈 수 있다는 생각도 있고, 쉽게 갈 수 있다는 생각도 있는데, 해외여행은 아무래도 나이가 들수록 시간에 쫓기다 보니까 조금 더 어릴 때 시간을 자유자재로 낼 수 있을 때 갔다 오자는 생각으로 해외여행을 함 (이보 $\mathrm{O}$, 오종 $\bigcirc)$

- 코로나와 상관없이 아이 유무에 따라 다른 것 같은데 아이가 없었을 때는 해외여행만을 고집했고, 아이가 생기면 장거리 여행이 어렵기 때문에 어쩔 수 없이 국내여행에 의존함 (이진)

\section{마. 국내여행 제약 및 촉진요인}

청년층은 국내여행에 대한 선호도가 낮은 이유에 대한 질문에 대표적으로 국내여행시 청년층에게 제공되는 인센티브의 부재, 지역 간 높은 유사성, 관광 매력물의 낮은 집적 도 및 연계성 등을 꼽았다.

특히 기초 지자체의 경우에는 대중교통을 이용한 이동의 불편함을 핵심 장애 요인으 로 응답하였는데, 광역 교통수단을 이용하여 지역 관광목적지에 내려가더라도 지역 내에 서 관광지 간 이동에 많은 시간이 소요되는데 따른 어려움을 호소하였다.

무엇보다 지역 내 관광 매력물의 집적도가 낮기 때문에 잦은 이동이 필요한데 비해서, 이용할 수 있는 교통수단은 한정되어 있으며, 제공되는 교통 정보가 부정확한 점은 젊은 청년층이 지역 관광지에 유입되는 것을 제약하는 요인이 되고 있다.

- 여행을 하려면 여행자로서 가고 싶은 목표나 강력한 인센티브가 있어야 하는데, 30 대 초반 청년은 20 대 (내일로패스)와 같이 적용 받을 수 있는 국내여행 인센티브가 부재함 (오혜 $\bigcirc$ )

- "산사를 가고 싶다", “트래킹을 가고 싶다" 이런 뚜렷한 목표가 없으면 어디를 가나 거기서 거기라는 생각 을 가지고 있음. 양구를 가든 양양을 가든 화천을 가든 다 비슷함 (오혜 $\bigcirc$ )

- 주요 고려사항은 "내가 그 지역에 놀러 갈만큼 매력이 있느냐, 즐길 거리가 있느냐"인데 괜찮은 곳을 찾아 도 막상 가면 여기는 정말 괜찮은데 연계되는 관광 매력물이 없어서 한 지역에서 깊게 관광을 할 수가 없음 (장윤ㄱ)

- 지방 여행지에 가면 배차 간격이 길고 대중교통 시간표가 맞지 않는 등 교통수단 이용에 불편함을 느낌. 좋은 관광지를 방문하고 싶어도 접근성이 떨어져서 한, 두 군데 방문하고 나면 이동시간이 많이 소요되어 일정이 끝남 (오종, 이보) 


\section{3. 소결}

본 절에서는 청년층(만 19세-34세)을 대상으로 표적집단면접을 실시하였으며, 면접 을 통해 결혼 여부, 경제활동 유무 등에 따른 청년층 내 관광 특성 차이를 다각도로 살펴 보고자 하였다.

조사 결과 청년층은 체험관광지 방문을 선호하고, 여행 의사결정 및 여행 중 정보획득 에 있어서 소셜미디어와 인터넷 정보를 폭넓게 활용하고 있었는데 이는 제2장에서 검토 한 MZ세대의 특성 및 제 3 장 제 1 절의 국민여행조사 원자료 분석결과와 일치한다.

또한 가구 형태에 따른 여행 행태와 코로나 19 의 영향으로 인한 여행 행태 변화와 관 련하여 다양한 의견이 개진되었는데, 표적집단면접 조사를 통해 나타난 청년층의 국내여 행 특성은 다음과 같다.

\section{가. 국내여행 및 해외여행 인식}

청년층은 국내여행보다 해외여행은 선호하는 것으로 나타났으며, 해외여행을 통해 국 내여행과 유사한 비용으로 일상 탈출의 경험을 추구하였다. 청년층에게 국내여행은 언제 든지 마음먹으면 떠날 수 있기 때문에 우선순위가 낮은 선택지로 여겨지나, 어린 자녀를 동반한 기혼 부부에게는 국내여행이 현실적으로 여행을 즐길수 있는 유일한 수단이었다.

\section{나. 국내여행을 선호하지 않는 이유, 불편 사항}

청년층이 국내여행을 선호하지 않는 이유는 언제든 떠날 수 있다는 접근성의 역설 외 에도 인센티브 부재, 지역간 유사성, 낮은 집적도, 불편한 이동수단 등 다양한 요인이 존재한다. 특히, 경제 활동기에 접어든 20대 후반 이상의 청년층에게 있어서 국내여행 비용을 보조해주는 경제적인 인센티브의 부재는 국내여행 대신 해외여행을 선택하게 하 는 요인으로 작용하였다. 또한 지역 간 차별화되는 콘텐츠가 부족하고, 관광 매력물 간 연계성이 낮은 것은 청년층이 국내여행을 선택하는데 큰 장애요인으로 작용되고 있으며, 지역 내 충분한 관광 매력물이 부재함에 따라 여행 중 관광목적지 내(또는 인접 지역으 로의) 잦은 이동이 요구되나, 편리한 대중교통 이용을 위한 인프라 및 정보 제공이 열악 하였다. 


\section{다. 국내여행 정보 활용}

청년층은 여행 의사결정 과정부터 여행지에서의 활동에 이르는 여행의 전 과정에 걸 쳐 블로그, 인스타그램, 유튜브, 포털사이트 등 소셜미디어와 인터넷 정보를 폭넓게 활 용하고 있었다. 특히, 여행지의 선택에는 인스타그램, 유튜브 등 시각정보 매체를 주로 활용하고, 실행을 위한 정보 취득은 네이버 블로그와 같이 텍스트 기반 매체를 활용하는 등 단계별, 기능별 필요성에 따라 다양한 경로로 여행정보를 구득하고 있다.

\section{라. 자녀(영유아) 동반 가구의 여행 행태}

청년층의 여행 경험은 생애주기에 따라 미혼자의 여행, 기혼자의 여행, 유아동반 여행 등 다양한 형태로 나타나고 있다. 이 가운데 유아를 동반하고 여행을 하는 가구는 청년 층의 타 집단과 비교해 상당한 여행행태의 차이를 드러내는데, 자녀의 안전을 고려한 숙소의 선택, 화장실 등 공공 편의시설 개선, 교육 콘텐츠에 대한 선호 등이 대표적 특성 으로 나타난다.

\section{마. 코로나19 이후 국내여행 행태 변화}

코로나19의 확산으로 청년층의 관광 행태에 상당한 변화를 나타났는데 국내여행의 증가, 다중이용 시설에 대한 회피, 위생과 방역 수칙 준수 여부 고려, 비대면 수업 방식 을 이용한 여행 시간의 증가 등이 대표적인 특징으로 드러났다. 청년층은 코로나19의 확산으로 인해 해외여행에 대한 제약이 발생하면서 국내여행 중심의 관광활동을 이어나 갔으며, 감염병에 대한 우려에 따라 다중이용 시설을 회피하고자 하는 노력을 기울이고 있다. 특히, 숙박시설 이용 시에는 저렴한 가격보다는 위생적인 환경과 방역지침 준수 여부를 우선적으로 고려하고 있으며, 숙박시설 예약 사이트를 통해 관련 정보를 철저히 검증하고 있었다. 한편 대학(원)생의 경우 비대면 수업의 도입으로 일상 활동 중 장소에 대한 제약이 완화되면서 여행 할 수 있는 시간이 증가한 것으로 나타났다. 


\section{제3절 청년층 국내관광 특성 심층 조사}

\section{1. 조사 개요}

\section{가. 조사 목적}

본 절에서는 국민여행조사 원자료 분석 및 표적집단면접 조사를 통해 드러난 청년관 광 정보를 바탕으로 보다 깊이 있는 청년층의 관광 특성을 파악하기 위한 온라인 조사를 수행하였다. 특히, 구조화된 설문지를 활용하여 청년층의 국내여행 경험이유, 국내여행 시 디지털 콘텐츠 활용, 여행경험 공유 방법 등 청년층 특유의 관광 행태를 구체적으로 알아보고자 하였으며, 국내여행 제약요인과 개선을 위해 필요한 사항 등 정책 수립 시 고려해야할 주요 사항을 확인하고자 하였다.

\section{나. 조사 설계}

본 조사의 모집단은 만19세 이상 만34세 이하 전 국민으로 하였으며, 주민등록 인구 통계를 활용한 표본 설계를 통해 1,000 명의 청년층을 대상으로 조사를 실시하였다. 표 본은 성별/연령대별/거주지역별 제곱근 비례 배분을 실시하였으며, 주민등록 인구통계 는 2021년 6월을 기준으로 활용하였다.

〈표 3-43〉 조사 설계

\begin{tabular}{c|l}
\hline 구분 & \multicolumn{1}{|c}{ 내용 } \\
\hline 조사 대상 & ・ 만19세 이상 만34세 이하 전국민 \\
\hline 조사 방법 & • 온라인 조사 \\
\hline 표본 크기 & $\bullet 1,000$ 개 \\
\hline 표본 배분 & ・ 성별/연령대별/거주지역별 제곱근 비례배분(주민등록 인구통계 06월 기준) \\
\hline 표본 추출 & ・ 층화계통추출 \\
\hline 조사 기간 & • 2020년 07월 26일 2020년 08월 04일 \\
\hline
\end{tabular}




\section{다. 조사 내용}

조사의 주요 질의 항목은 청년층의 국내여행 특성, 국내여행 제약 요인, 국내여행에 대한 평가, 국내여행 활성화를 위한 개선 사항 등 6 개 부문으로 구성되었다. 조사 항목 은 국민여행 조사 원자료 분석 및 청년층 표적집단면접 조사의 결과를 보완하여 청년층 의 국내관광 특성에 심층적으로 접근할 수 있도록 설계되었다.

조사 항목의 구성을 위해 문체부, 한국관광공사 등 정책의 수립 및 실행을 담당하고 있는 이해관계자를 대상으로 정책 간담회를 실시하는 한편, 관광부문 전문가를 대상으로 조사 항목의 구성에 대한 자문을 실시하였다. 청년층 대상 전 국민 조사를 위한 세부항 목은 다음 〈표 3-44〉와 같다.

또한 본 절에서는 청년층을 연령대, 직업, 자녀 여부 등에 따라 분류하고 해당 특성에 따른 분석을 병행함으로써 정책방향 설정을 위해 세분 집단별 특성을 함께 제시하고자 하였다.

〈표 3-44〉 조사 항목

\begin{tabular}{|c|c|}
\hline 구분 & 내용 \\
\hline $\begin{array}{l}\text { 응답자 } \\
\text { 정보 }\end{array}$ & $\begin{array}{l}\text { - 성별/연령/거주지/직업 } \\
\text { - 가구 소득/개인 소득/자가용 보유 여부 } \\
\text { - 소득 대비 국내여행 지출 비중/결혼 상태/자녀 유무 }\end{array}$ \\
\hline $\begin{array}{c}\text { 국내여행 } \\
\text { 특성 }\end{array}$ & $\begin{array}{l}\text { - (가장 최근) 여행 기간 } \\
\text { - (가장 최근) 연차 사용 여부 및 사용 기간 } \\
\text { - (가장 최근) 목적지 및 선택 이유 } \\
\text { - (가장 최근) 이동 시간/동반자 유형/경비마련 방법/이용 교통수단 } \\
\text { - (가장 최근) 숙박시설/예약 채널/주요 고려 정보 } \\
\text { - 국내여행 경험 이유 } \\
\text { - 국내여ㅎㅐㅐ 유발/계획 관련 디지털 콘텐츠 유형 } \\
\text { - 여행경험 공유 여부 및 방법 }\end{array}$ \\
\hline $\begin{array}{c}\text { 국내여행 } \\
\text { 제약 }\end{array}$ & $\begin{array}{l}\text { - 국내여행 제약 요인 } \\
\text { - 국내여행 할 시간이 없는 이유 } \\
\text { - 불편한 관광 인프라 } \\
\text { - 비용 부담이 큰 항목 } \\
\text { - 재방문 의향 및 이유 }\end{array}$ \\
\hline $\begin{array}{c}\text { 국내여행 } \\
\text { 평가 }\end{array}$ & - 국내여행 정보/인프라/서비스/콘텐츠/안전도 등 \\
\hline 국내여행 개선사항 & $\begin{array}{l}\text { - 국내여행 활성화를 위한 중요도 } \\
\text { - 민간 및 공공 역할 } \\
\text { - 정부 추진 필요 정책 }\end{array}$ \\
\hline
\end{tabular}




\section{2. 조사 결과}

\section{가. 국내여행 특성}

1) 최근 여행 기간

응답자의 73.6\%는 국내여행 시 '숙박여행'을 경험하였으며, 평균 숙박여행 기간은 2.8 일로 나타났다. ‘당일여행' 응답 비율은 무직(53.3\%), ‘숙박여행' 은 직장인(77.6\%)에 서 상대적으로 높게 조사되었다.

[그림 3-2] 최근 여행 기간

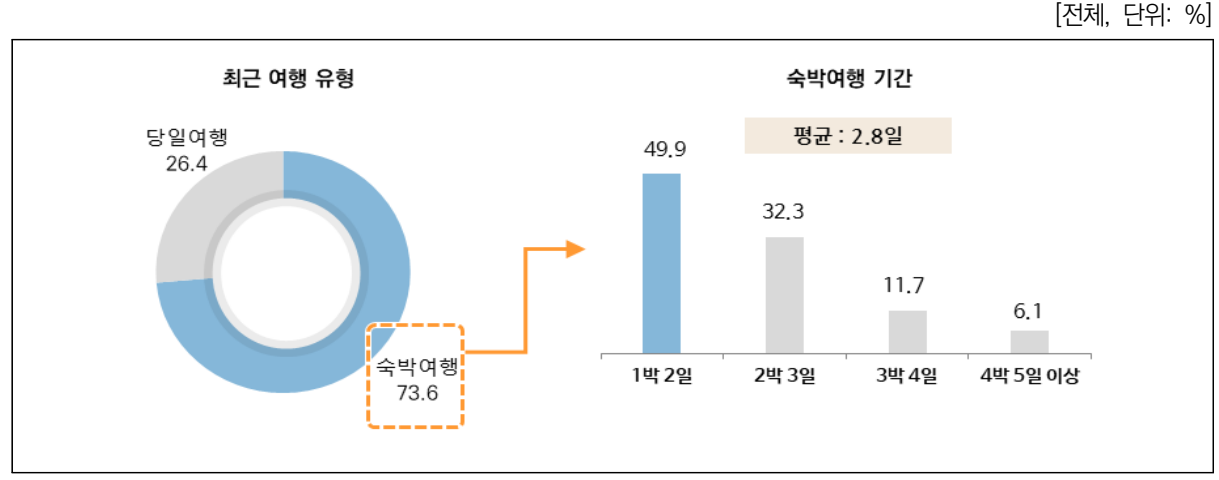

2) 연차 사용 여부

직장인의 $40.3 \%$ 는 국내여행 시 연차를 사용하고 있었으며, 평균 연차 기간은 2.2 일 이었다. 자녀가 있는 청년의 경우, 연차 사용률(65.1\%)이 상대적으로 높은 것으로 확인되었다.

[그림 3-3] 연차 사용

[직장인, 단위: \%]

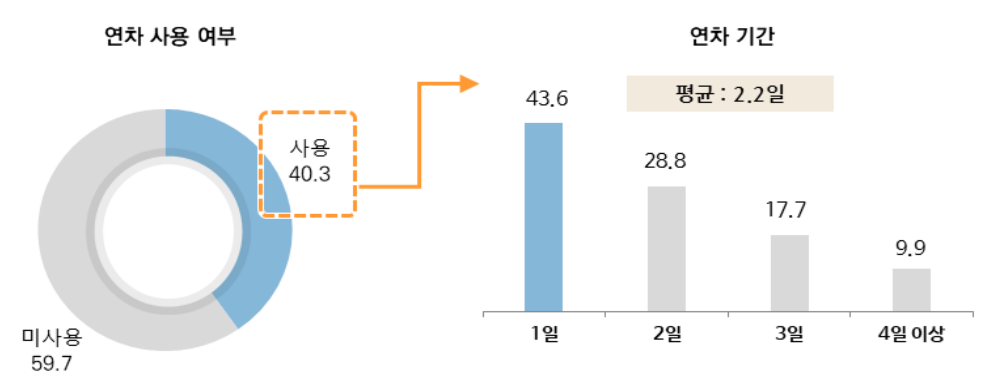




\section{3) 목적지 선택 이유}

가장 최근에 다녀온 국내여행 목적지를 선택한 이유로는 '가까운 이동거리 때문에'(1 순위 $27.0 \%, 1+2+3$ 순위 $40.1 \%$ )라는 응답이 가장 높은 것으로 나타났다. 이어서 '해당 지역만의 고유한 특성을 느끼기 위해서' $(1+2+3$ 순위 $39.5 \%)$, '전망, 사진촬영 때문 에'(1+2+3순위 30.2\%), '가고 싶은 맛집이 있어서'(1+2+3순위 29.8\%) 등이 높은 순위 로 조사되었다. 집단별로는 19-29세, 대학(원)생 등에서 '가까운 이동거리 때문에', '전 망, 사진촬영 때문에', '가고 싶은 맛집이 있어서' 등이 평균 대비 높은 응답을 보였다.

[그림 3-4] 목적지 선택 이유_상위 10개 항목

[전체, 단위: \%]

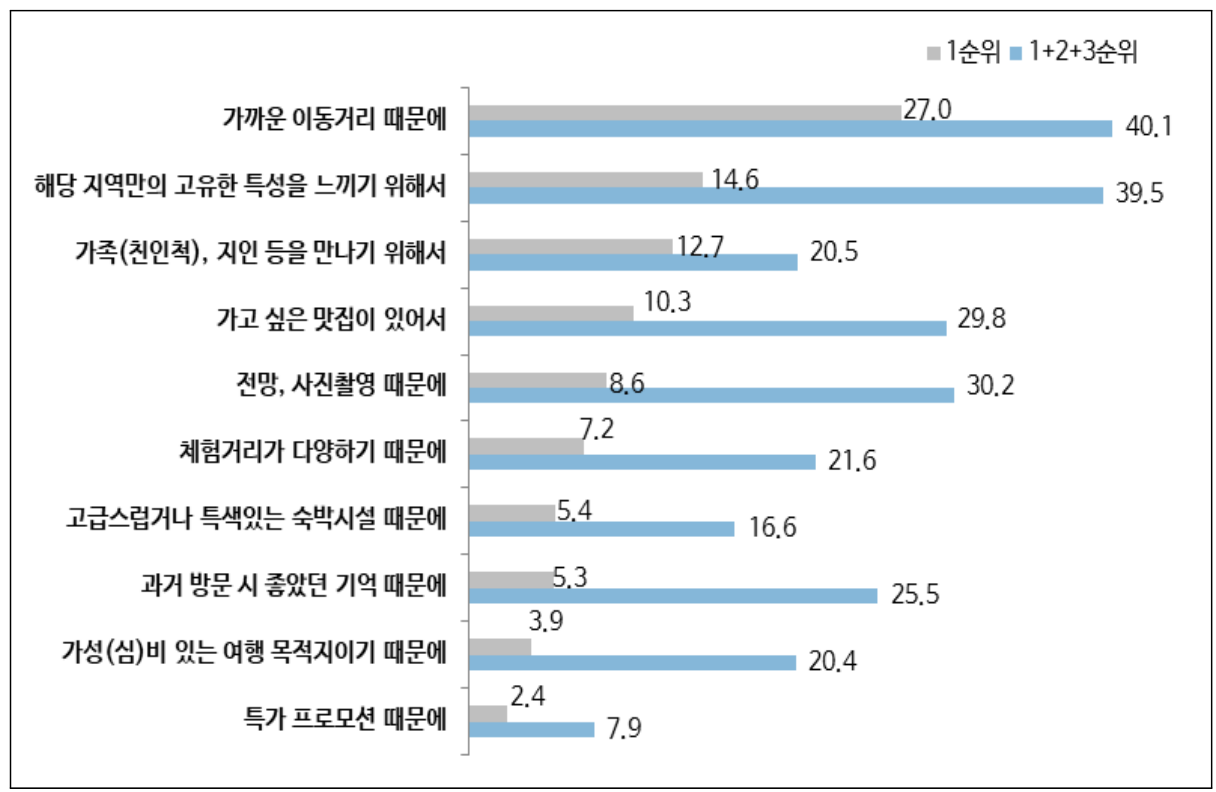

4) 이동시간

국내여행 시, 출발지에서 목적지까지의 이동시간은 '2시간 이하' (48.1\%)가 가장 많 으며, 이동시간이 길수록 응답 비율이 낮은 경향을 보였다.

19-29세, 무직, 아르바이트, 자녀동반 가구 등에서 상대적으로 '2시간 이하'에 대한 응답률이 높았으며, 30-34세, '직장인', '자영업' 등에서 전체 대비 '5-8시간'에 대한 응 답이 높은 것으로 확인되었다. 


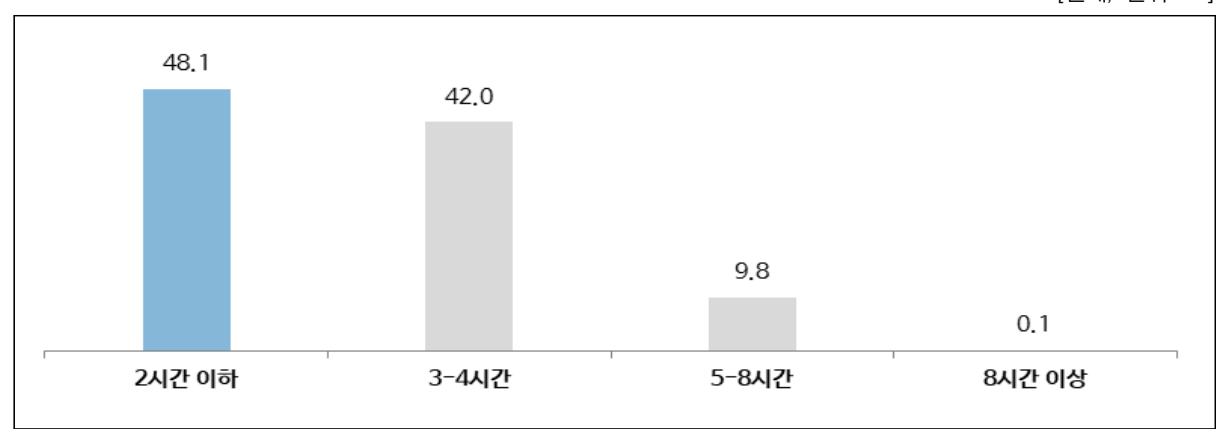

\section{5) 동반 유형}

청년층의 국내여행 동반자로는 '친구'(33.0\%)가 가장 많았으며, '가족/친지(영유아/ 어린이 미동반)'(28.6\%). '연인'(22.3\%) 등의 순서로 나타났다. '혼자' 여행을 다녀온 비 율 또한 $10.3 \%$ 였으며, '가족/친지(영유아/어린이 동반)'에 대한 응답도 $8.9 \%$ 를 차지하 였다. 직업별로 밨을 때, '친구'는 대학(원)생(47.8\%)에서 가장 높으며, '혼자'는 무직 (20.0\%), '아르바이트'(19.4\%) 등에서 높았다.

\section{[그림 3-6] 동반 유형}

[전체, 단위: \%]

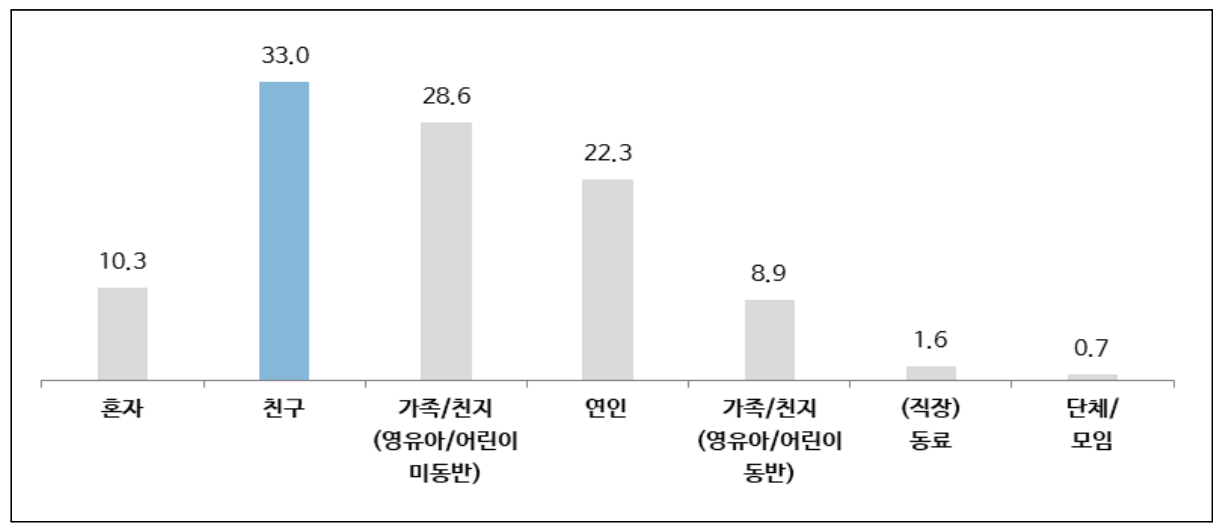

6) 비용 마련 방법

청년층에게 국내여행에서 본인 몫의 비용을 어떻게 마련했는지 물었을 때, '전액 본인 스스로 경제활동을 통해 마련' 했다는 응답이 $68.7 \%$ 로 가장 많았다. '전액 본인 스스로 
경제활동을 통해 마련' 했다는 응답은 30-34세(78.1\%) 및 직장인(81.6\%)에서 높은 것으 로 나타났으나, 직업이 없는 무직(1+2순위 $80.0 \%)$, 대학(원)생(1+2순위 40.8\%) 청년들 의 상당수가 '전액 또는 일부 경비를 가족/친지의 지원을 통해 마련' 했다고 응답하였다.

[그림 3-7] 비용 마련 방법

[전체, 단위: \%]

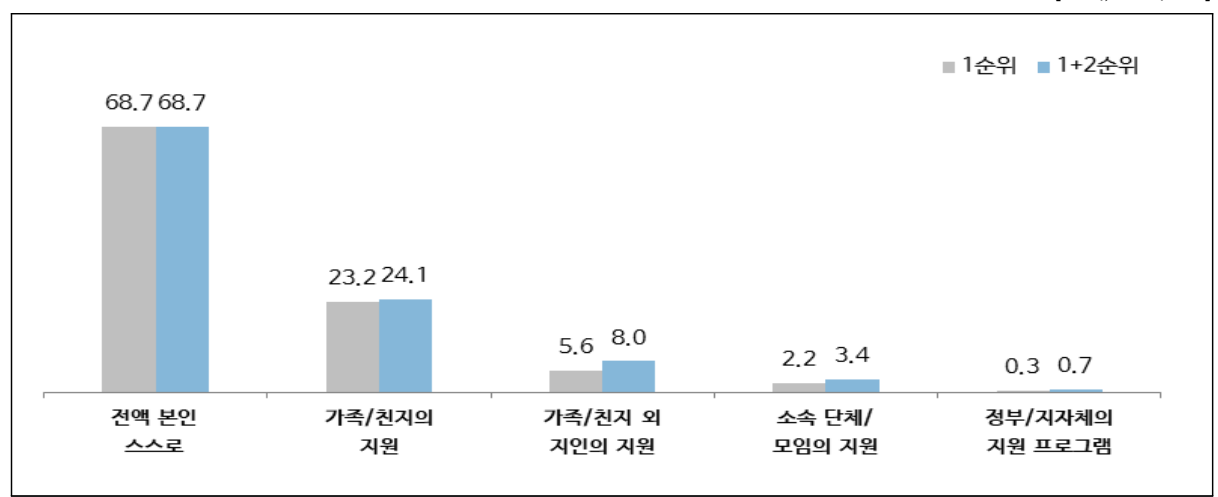

7) 교통수단

(1) 이용 교통수단

청년들의 과반 이상은 국내여행 시 '자가용'(54.7\%)을 이용한 것으로 조사되었으며, '시내/시외/고속버스'(21.2\%), '기차'(18.8\%) 등의 순서로 뒤를 이었다. 특히 30-34세 (66.2\%)와 자녀 있음(82.2\%)등에서 '자가용'은 응답 비율이 높았으며, 대학(원)생에서 '시내/시외/고속버스'(39.9\%), '기차'(25.9\%), ‘항공기'(21.1\%) 등 대중교통 이용 비율 이 높은 것으로 나타났다.

[그림 3-8] 교통수단(복수응답)

[전체, 단위: \%]

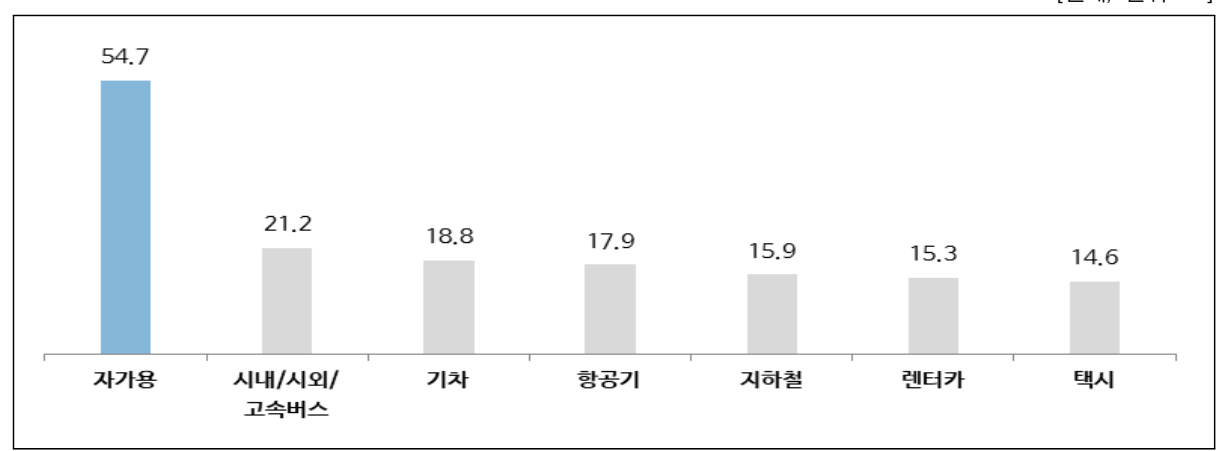

74 국내관광 활성화를 위한 청년관광 실태 분석 및 정책방안 
(2) 자가용/렌터카 이용 이유

국내여행에서 자가용 또는 렌터카를 이용한 이유로는 '국내여행 목적지까지 쉽고 빠 르게 이동할 수 있기 때문에'(56.7\%)라는 응답이 가장 많았고, ‘자유로운 여행 일 정'(33.6\%)때문 이라는 응답이 뒤를 이었다.

특히, 자녀가 있는 청년층(62.5\%)에서 '국내여행 목적지까지 쉽고 빠르게 이동할 수 있기 때문에'이라는 응답이 높은 응답 비율을 보였다.

[그림 3-9] 자가용/렌터카 이용 이유

[자가용/렌터카 이용자, 단위: \%]

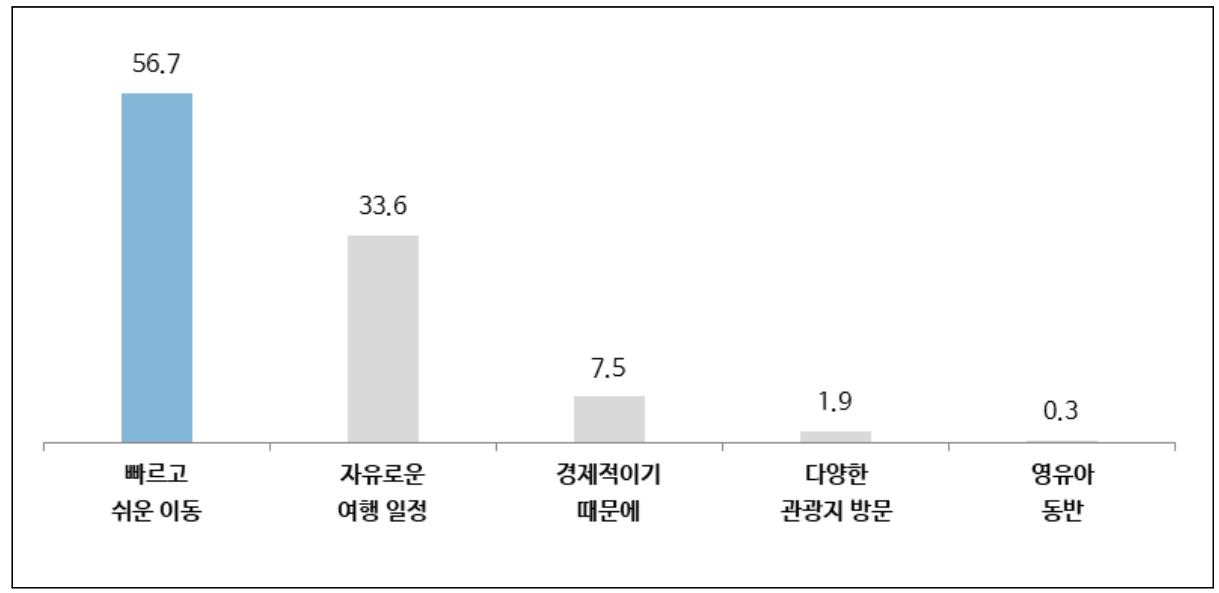

(3) 대중교통 이용 이유

국내여행에서 대중교통을 이용한 청년들에게 그 이유를 물었을 때, '자가용/렌터카'이 용자와 마찬가지로 '국내여행 목적지까지 빠르게 이동할 수 있기 때문에'(44.8\%)라는 응 답이 가장 높은 것으로 나타났다. 특히, 30-34세(51.6\%)에서 '국내여행 목적지까지 빠 르게 이동할 수 있기 때문에' 대중교통을 이용하는 것으로 나타났으며, 반면 대학(원)생 (33.3\%)은 상대적으로 경제적이기 때문에 대중교통을 이용하는 것으로 조사되었다. 


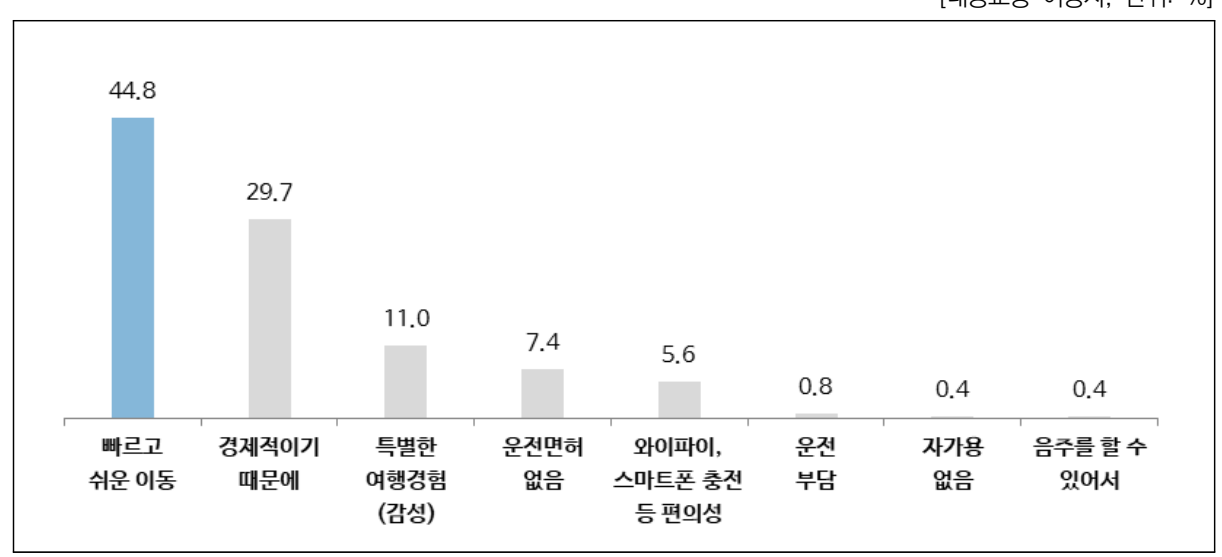

\section{8) 숙박시설}

(1) 이용 숙박시설

청년층이 국내여행에서 이용한 숙박시설로는 ‘호텔’(45.2\%)이 가장 많은 응답을 기록 하였으며, '펜션'(24.2\%), ‘모텔/여관'(12.0\%) 등의 순서로 조사되었다.

직장인들의 절반 정도가 ‘호텔'(50.1\%)을 이용한 것으로 나타났으며, 자녀동반 가구 의 경우 상대적으로 '펜션'(27.9\%) 및 '콘도미니엄'(24.6\%) 이용 비율이 높은 것으로 나 타났다.

\section{[그림 3-11] 이용 숙박시설_상위 10 개 항목}

[숙박여행자, 단위: \%]

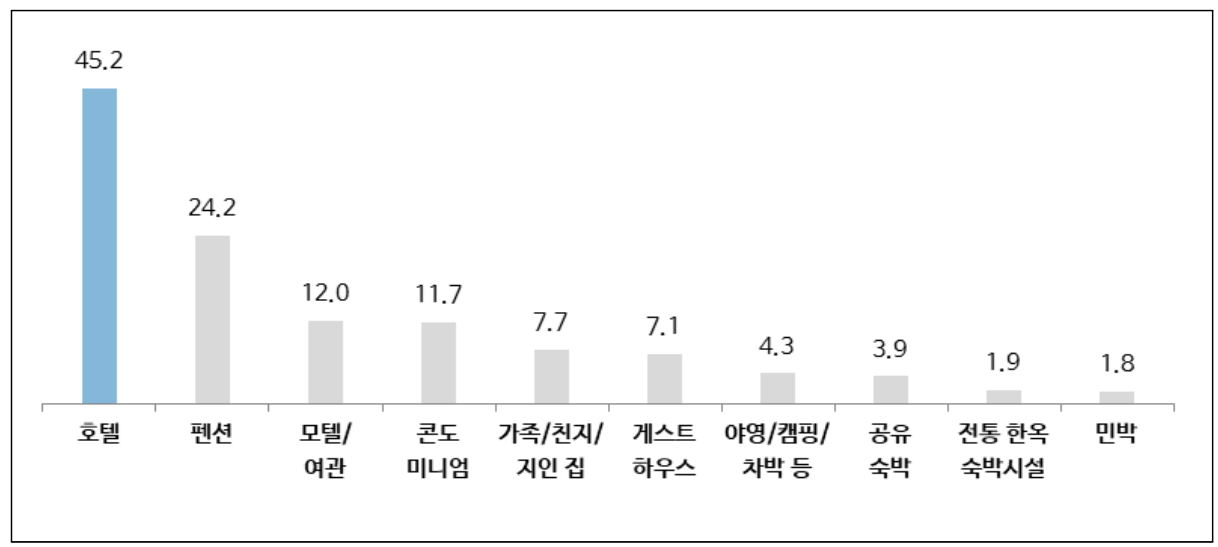

76 국내관광 활성화를 위한 청년관광 실태 분석 및 정책방안 


\section{(2) 숙박시설 구매/예약처}

숙박시설 이용자를 대상으로 숙박시설 구매/예약처에 대해 질문한 결과 과반 이상이 야놀자, 호텔스닷컴 등의 '숙박예약 플랫폼' (58.0\%)을 통해 숙박시설을 구매/예약한 것 으로 나타났다. 한편 자녀동반 가구의 경우 ‘숙박시설 공식 채널'(40.4\%)을 통해 숙박시 설을 구매하거나 예약한 비중이 상대적으로 높은 것으로 조사되었다.

[그림 3-12] 숙박시설 구매/예약처(복수응답)

[숙박시설 이용자, 단위: \%]

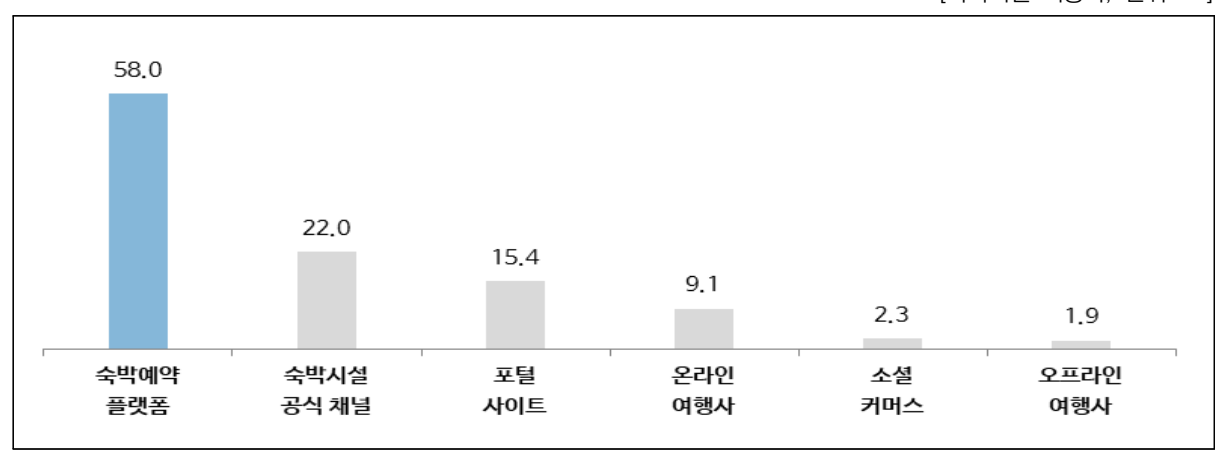

(3) 숙박시설 고려요인

숙박시설을 구매/예약할 때, 중요하게 고려하는 요인으로는 '비용/가격'(1순위 $57.2 \%, 1+2+3$ 순위 $85.2 \%)$ 이 가장 높았으며, '객실 청결 및 위생상태' $(1$ 순위 $18.9 \%$, $1+2+3$ 순위 66.2\%)가 두 번째로 높은 것으로 나타났다. 한편, 1 순위 기준으로 대학(원) 생에서 '비용/가격'(68.6\%) 응답이 가장 높았으며, '객실 청결 및 위생상태'는 자녀동반 가구에서 가장 높은 것으로 나타났다.

[그림 3-13] 숙박시설 고려요인

[숙박시설 이용자, 단위: \%]

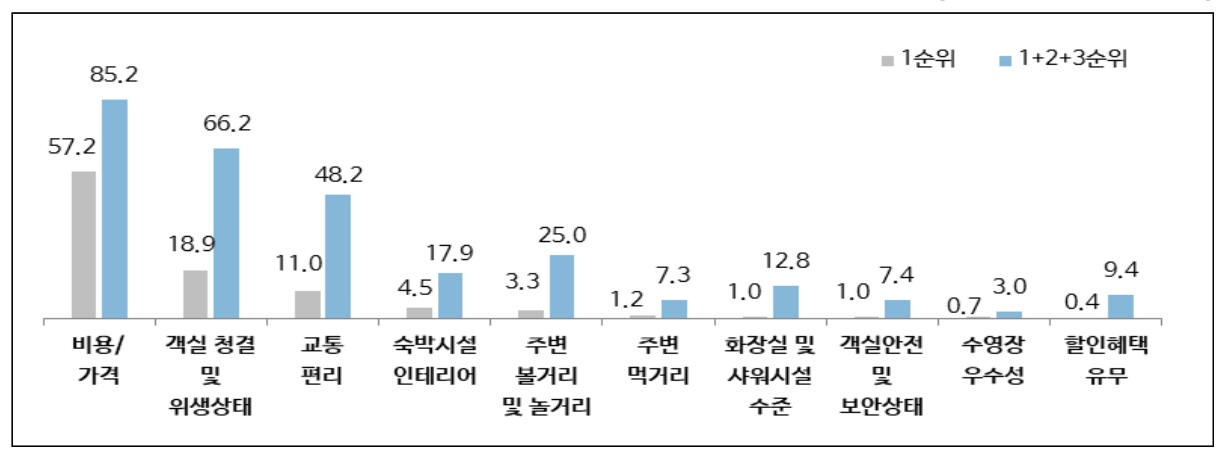




\section{9) 국내여행을 하는 이유}

청년층은 평소 다른 여가 활동과 비교해 국내여행을 하는 이유에 대해서, '짧은 휴가기 간을 이용하여 여행이 가능하기 때문에'(1순위 $32.0 \%, 1+2+3$ 순위 53.4\%)라는 항목에 가장 높은 응답률을 보였다. $1+2+3$ 순위 기준으로 '계획 없이 즉흥적으로 국내여행이 가 능하기 때문에'(39.5\%), '지역별 먹거리와 맛집'(35.1\%), '힐링, 휴식 등을 경험'(34.8\%) 등이 뒤를 이었으며, 30-34세(58.2\%), 직장인(56.8\%), 아르바이트(56.5\%) 등에서 '짧은 휴가기간을 이용하여 여행이 가능하기 때문에'라는 응답 비중이 특히 높았다.

[그림 3-14] 국내여행을 하는 이유

[전체, 단위: \%]

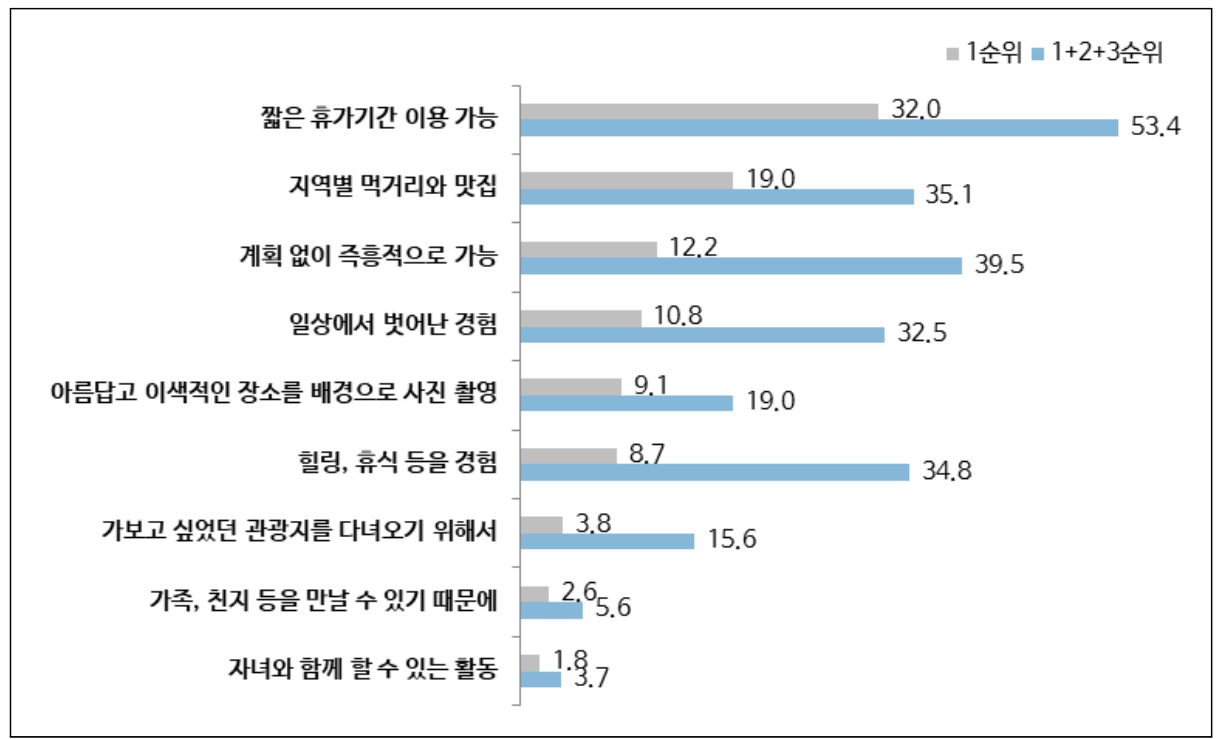

10) 디지털 콘텐츠 이용

(1) 국내여행 유도 콘텐츠 유형

청년들에게 국내여행 욕구를 불러일으키는(가고 싶게 만드는) 디지털 콘텐츠 유형으 로는 '관광 매력물의 사진과 해시태그로 구성된 SNS 콘텐츠'(1순위 24.7\%, $1+2+3$ 순위 $51.5 \%)$ 가 가장 높게 나타났으며, '여행후기 형식의 영상물' $(1+2+3$ 순위 50.1\%), '장문 의 텍스트로 설명된 여행 후기 콘텐츠'(38.5\%) 등이 뒤를 이었다.

1 순위 기준으로 봤을 때, '관광 매력물의 사진과 해시태그로 구성된 SNS 콘텐츠'는 
자녀가 있는 청년층(33.3\%)에서 높으며, '크리에이터가 국내여행 과정을 소개하는 여행 후기 형식의 영상물'은 대학(원)생(29.4\%)에서 높은 응답을 보였다.

[그림 3-15] 국내여행 유도 콘텐츠 유형

[전체, 단위: \%]

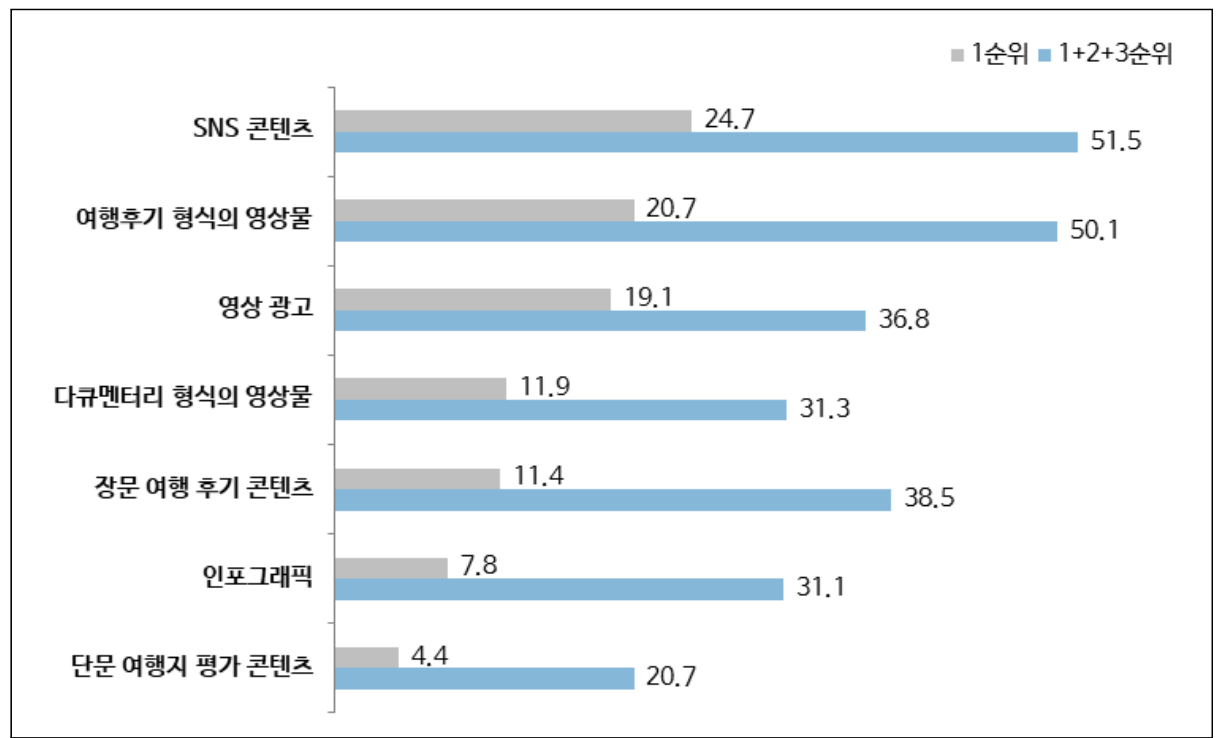

(2) 국내여행 계획 콘텐츠 유형

평소 청년들이 국내여행을 계획할 때, 주로 이용하는 여행정보 디지털 콘텐츠 유형 은 '관광 매력물의 사진과 해시태그로 구성된 SNS 콘텐츠'(1순위 $28.2 \%, 1+2+3$ 순위 $57.0 \%)$ 인 것으로 확인되었다. 이어서 '여행 후기 형식의 영상물' $(1+2+3$ 순위 $51.6 \%)$

'장문 여행 후기 콘텐츠' $(1+2+3$ 순위 $49.1 \%)$ 등의 순서로 응답률을 기록하였다.

연령대별로 살펴봤을 때 19-29세에서 SNS 콘텐츠'(1+2+3순위 61.5\%), '여행 후기 형식의 영상물' $(1+2+3$ 순위 $52.4 \%)$, '장문 여행 후기 콘텐츠' $(1+2+3$ 순위 $49.3 \%)$ 등의 콘텐츠 유형이 평균 대비 높은 응답률을 보였고, 30-34세에서는 '인포그래팍' $(1+2+3$ 순 위 34.8\%), '영상 광고'(1+2+3순위 $29.0 \%$ ) 에 대한 응답률이 높았다. 
[그림 3-16] 국내여행 계획 콘텐츠 유형

[전체, 단위: \%]

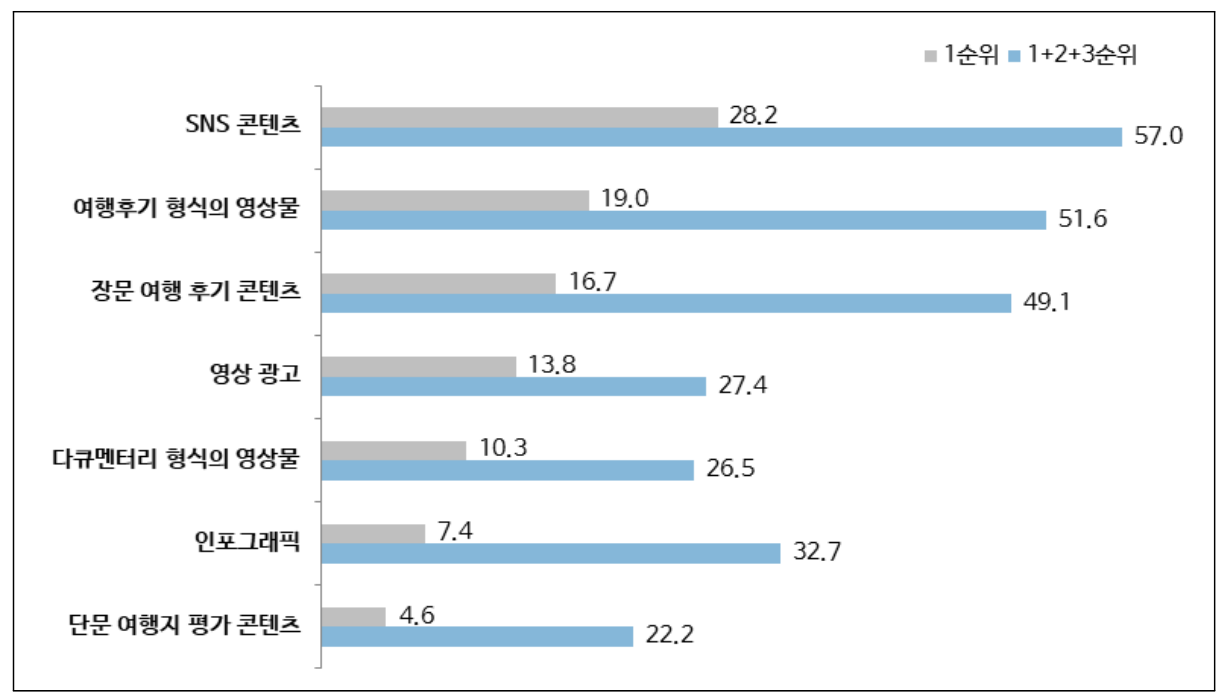

11) 온라인 공유 경험

(1) 온라인 공유 경험

청년들의 $60.1 \%$ 는 다녀온 여행 경험을 온라인에 공유한 적이 있으며, '여행이 매우 좋거나 혹은 나쁜 경우에 공유'(31.5\%)하는 경우가 많았다.

연령별로 살펴보면 19-29세에서 '매번 다녀온 여행에 대해 공유'(30.2\%)한다는 응답 이 평균 대비 많았으며, 30-34세에서는 '공유한 적 없음'(42.8\%)이라는 응답이 상대적 으로 많았다.

[그림 3-17] 온라인 공유 경험

[전체, 단위: \%]

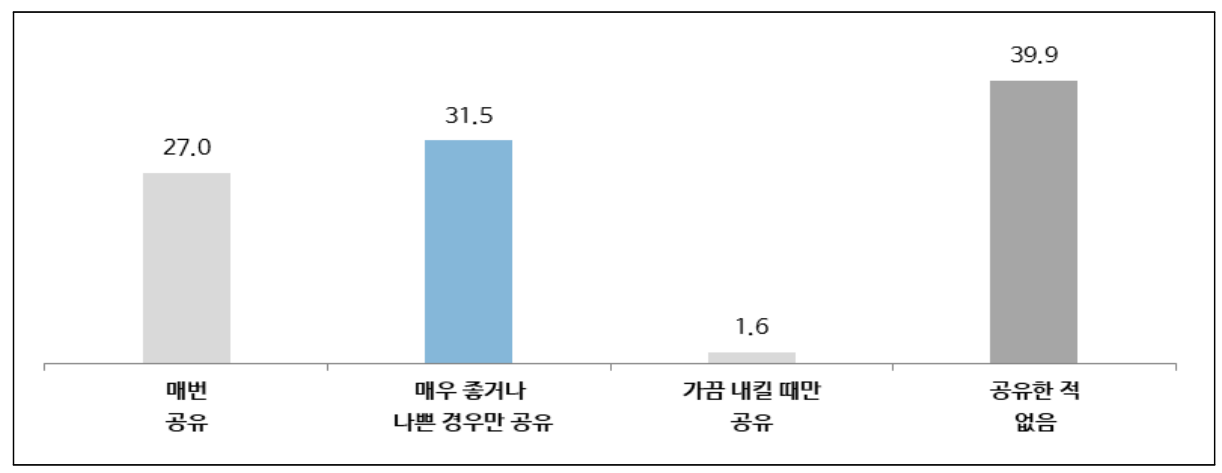

80 국내관광 활성화를 위한 청년관광 실태 분석 및 정책방안 


\section{2) 온라인 공유 방법}

여행 경험을 온라인에 공유한 청년들의 공유 방법으로는 '관광 매력물의 사진과 해시 태그로 구성된 SNS 콘텐츠'(1순위 53.8\%, 1+2+3순위 70.6\%)가 가장 많았고, 이어서 '장문 여행 후기 콘텐츠' $(1+2+3$ 순위 $49.2 \%)$, '단문 여행지 평가 콘텐츠' $(1+2+3$ 순위 $33.5 \%)$ 등의 형식으로 온라인 후기를 공유하고 있었다.

[그림 3-18] 온라인 공유 방법

[온라인 공유 경험자, 단위: \%]

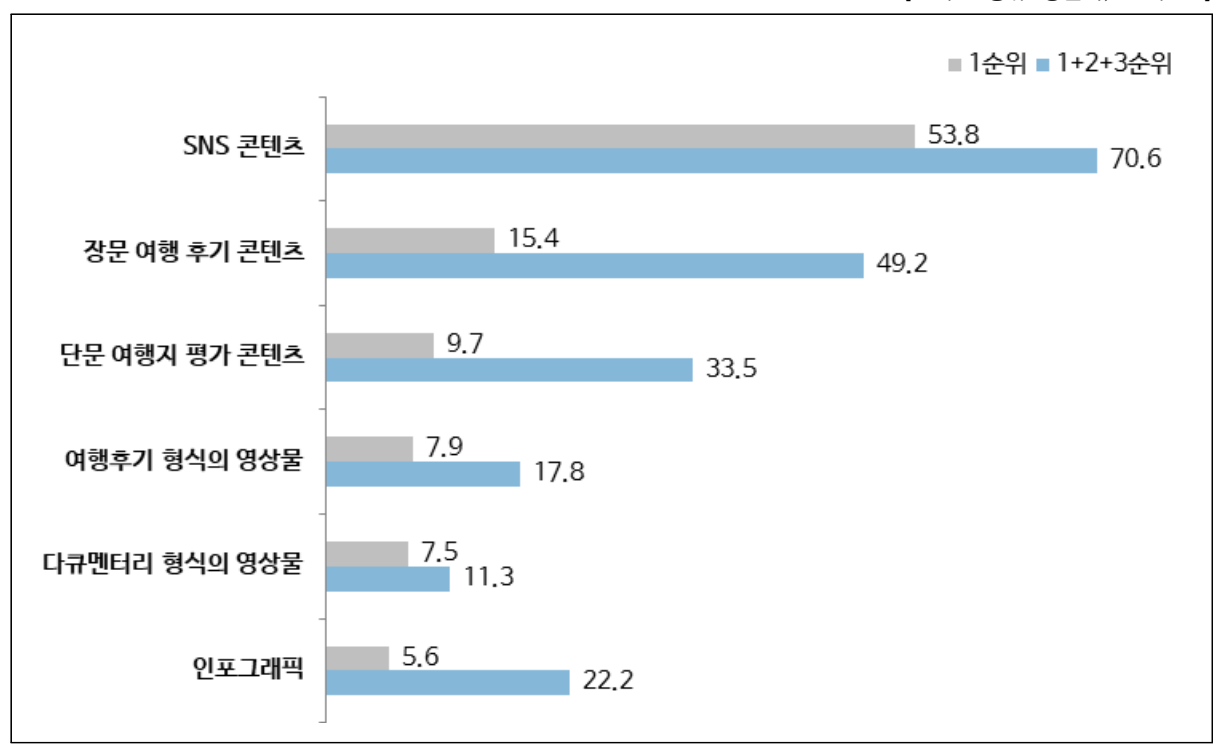

\section{나. 국내여행 제약 요인}

1) 국내여행 제약 요인 평가

청년들의 국내여행 제약 요인으로는 '국내여행을 할 시간이 없다'(23.2\%)가 가장 높 은 응답을 기록하였다. 이어서 '관광 인프라 부족'(18.1\%), '경제적 여유 없음'(17.8\%) 등을 주요 제약요인으로 꼽았으며, '정보 부족' 때문이라는 응답 또한 $15.4 \%$ 를 차지하였 다. 직업별로 살펴보면 직장인 '국내여행을 할 시간이 없다'는 응답이 많았으며, 무직, 대학(원)생, 아르바이트 등에서는 '국내여행을 할 경제적 여유가 없다'에 동의하는 비율 이 높았다. 
[그림 3-19] 국내여행 제약 요인 평가(긍정 응답 비율)

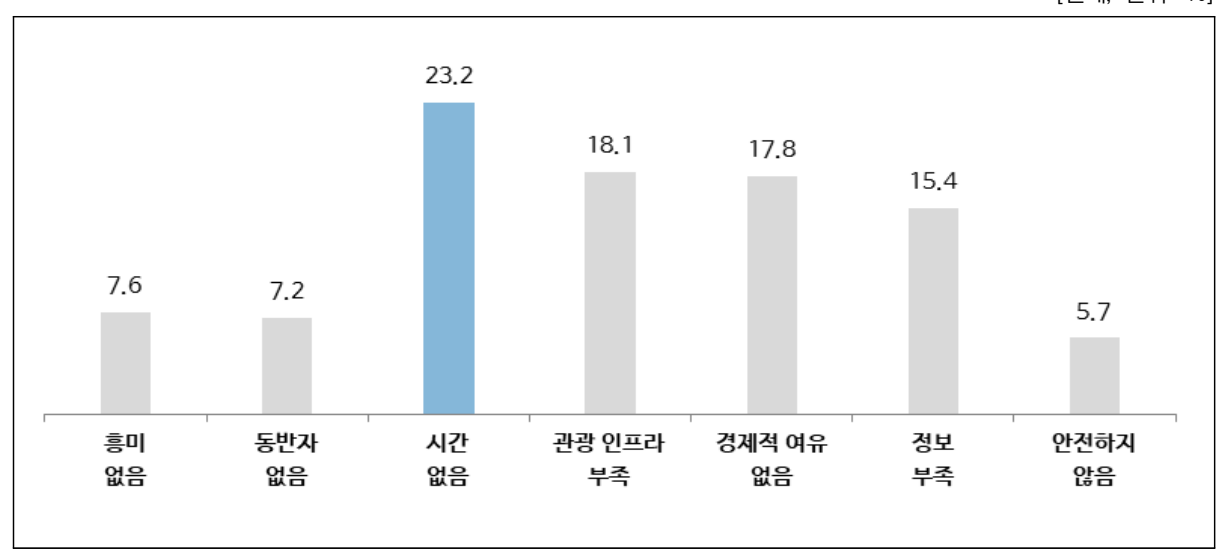

\section{2) 국내여행 시간 부족 이유}

국내여행을 할 시간이 없다고 응답한 이유에 대해서는 '국내여행을 위해 휴가를 내기 어려운 직장 분위기'(1순위 및 $1+2$ 순위 $40.9 \%$ )라는 응답이 가장 높은 응답률을 보였으 며, '주5일 근무제 미시행 등 근로시간 부담'(1+2순위 28.0\%), '학업/취업 준비 등에 대한 부담' $(1+2$ 순위 $22.4 \%)$ 등의 순서로 뒤를이었다. '학업/취업준비 등에 대한 부담' 은 19-29세(1+2순위 30.3\%)에서 상대적으로 높은 반면, '국내여행을 위해 휴가를 내기 어려운 직장 분위기'는 30-34세(1+2순위 54.5\%)에서 높았다.

[그림 3-20] 국내여행 시간 부족 이유

['시간 없음' 긍정 응답자, 단위: \%]

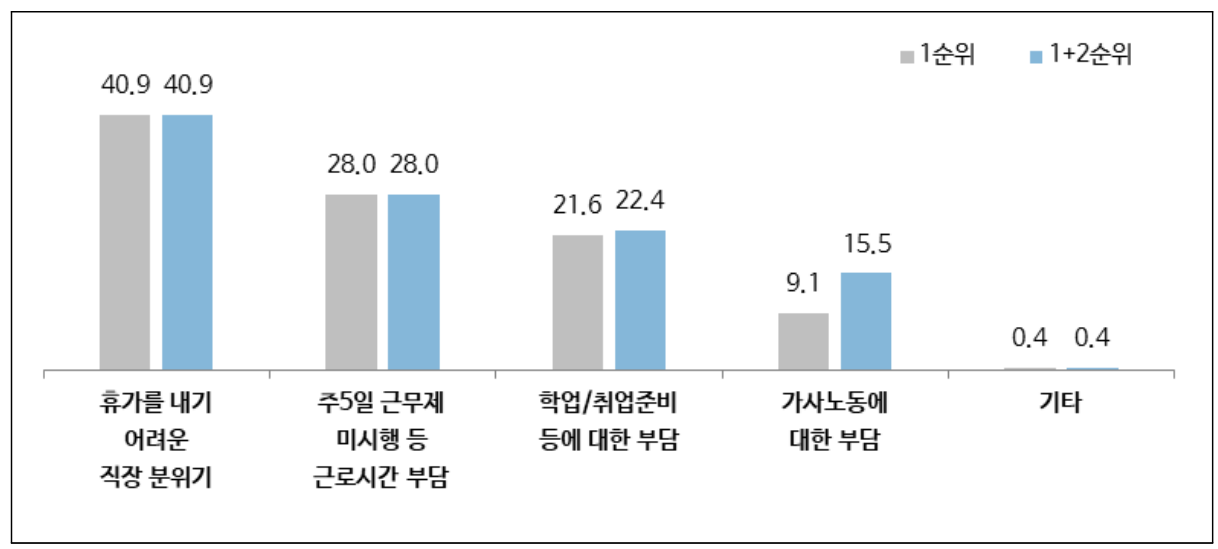




\section{3) 불편한 관광 인프라}

국내여행을 위한 관광 인프라 중 불편한 것이 무엇인지 물었을 때, '관광지역까지 이 동할 교통수단'(1순위 36.5\%, 1+2순위 54.7\%)과 '관광지역 내에서의 이동을 위한 교통 수단'(1순위 36.5\%,1+2순위 63.0\%)가 가장 높은 응답을 보였으며, '숙박시설' $(1+2$ 순 위 38.7\%)이 뒤를 이었다. 한편, 자녀동반 가구의 경우 '동반자를 위한 편의시설 및 서 비스'(1+2순위 40.0\%)가 상대적으로 높은 응답률을 기록하였다.

[그림 3-21] 불편한 관광 인프라

['관광 인프라 불편' 긍정 응답자, 단위: \%]

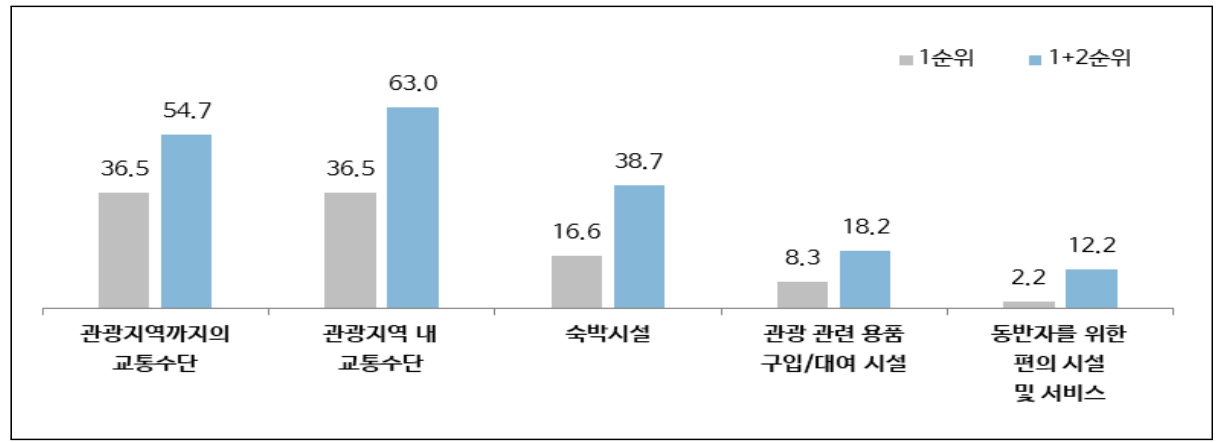

\section{4) 비용 부담 항목}

평소 국내여행 시 바용 부담이 크다고 생각한 항목으로는 $1+2$ 순위 기준 ‘숙박비’ $(88.8 \%)$, ‘식/음료비'(51.1\%), ‘교통비'(40.4\%) 등의 순으로 높은 응답률을 보였다. 비용 부담 항목의 경우, 응답자 특성에 따른 응답 비율의 차이가 크지 않은 것으로 조사되었다.

[그림 3-22] 비용 부담 항목

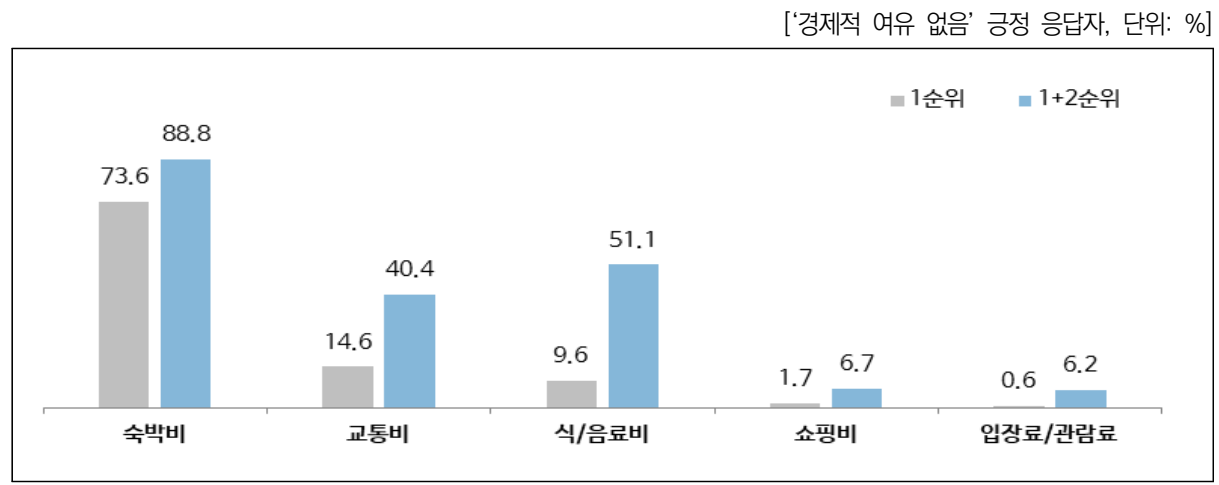




\section{5) 재방문 의향}

(1) 재방문 의향

가장 최근에 다녀온 국내여행 목적지를 향후 1 년 이내에 다시 방문할 의향이 있는지 물었을 때, 청년층의 66.0\%는 '그렇다'고 응답하였다.

재방문 의향 항목의 경우, 응답자 특성에 따른 응답 비율의 차이가 크지 않은 것으로 조사되었다.

[그림 3-23] 재방문 의향

[전체, 단위: \%]

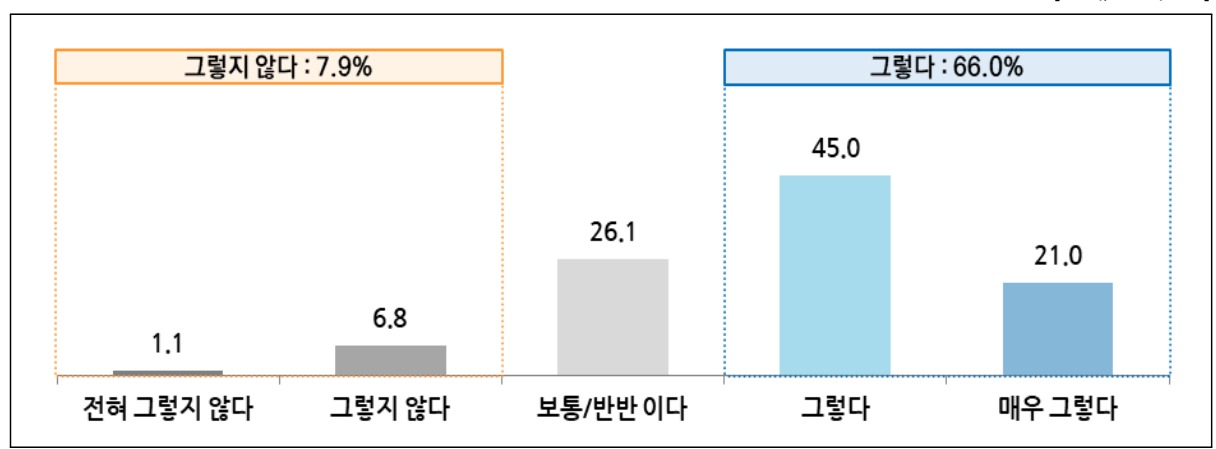

(2) 재방문 의향 이유

재방문 의향이 없는 청년들에게 그 이유를 물었을 때, '지금까지 가보지 않은 새로운 곳으로 국내여행을 다녀오고 싶어서'(1순위 $46.8 \%, 1+2+3$ 순위 $65.8 \%$ )라는 응답이 가 장 많았다. 다음으로 '교통 관련 인프라가 불편해서' $(1+2$ 순위 $30.4 \%)$, ‘볼거리가 부족해 서'(29.1\%), '경제적으로 부담되서'(25.3\%) 등이 꼽혔다.

한편 직장인은 '지금까지 가보지 않은 새로운 곳으로 국내여행을 다녀오고 싶어 서'(72.2\%)라는 응답이 상대적으로 높은 것으로 확인되었다.

다시 방문할 의향이 있는 청년들에게 그 이유를 물었을 때, '경제적으로 부담이 되지 않아서'(1순위 $27.3 \%, 1+2+3$ 순위 $46.8 \%$ )라는 응답이 가장 많았다. 이어서 '볼거리가 충분해서'( $1+2+3$ 순위 $45.6 \%)$, '먹거리가 충분해서'(1+2+3순위 $44.4 \%)$, '교통관련 인 프라가 편리해서' $(1+2+3$ 순위 $42.1 \%)$ 등의 순서로 많은 응답이 나타났다. 한편 '먹거리 가 충분해서'라는 응답은 1 순위(10.6\%)에서는 높지 않았으나, $1+2+3$ 순위(44.4\%)에서 는 높은 응답 비율을 보였다. 
[그림 3-24] 재방문 의향 없는 이유

[재방문 의향 없음, 단위: \%]

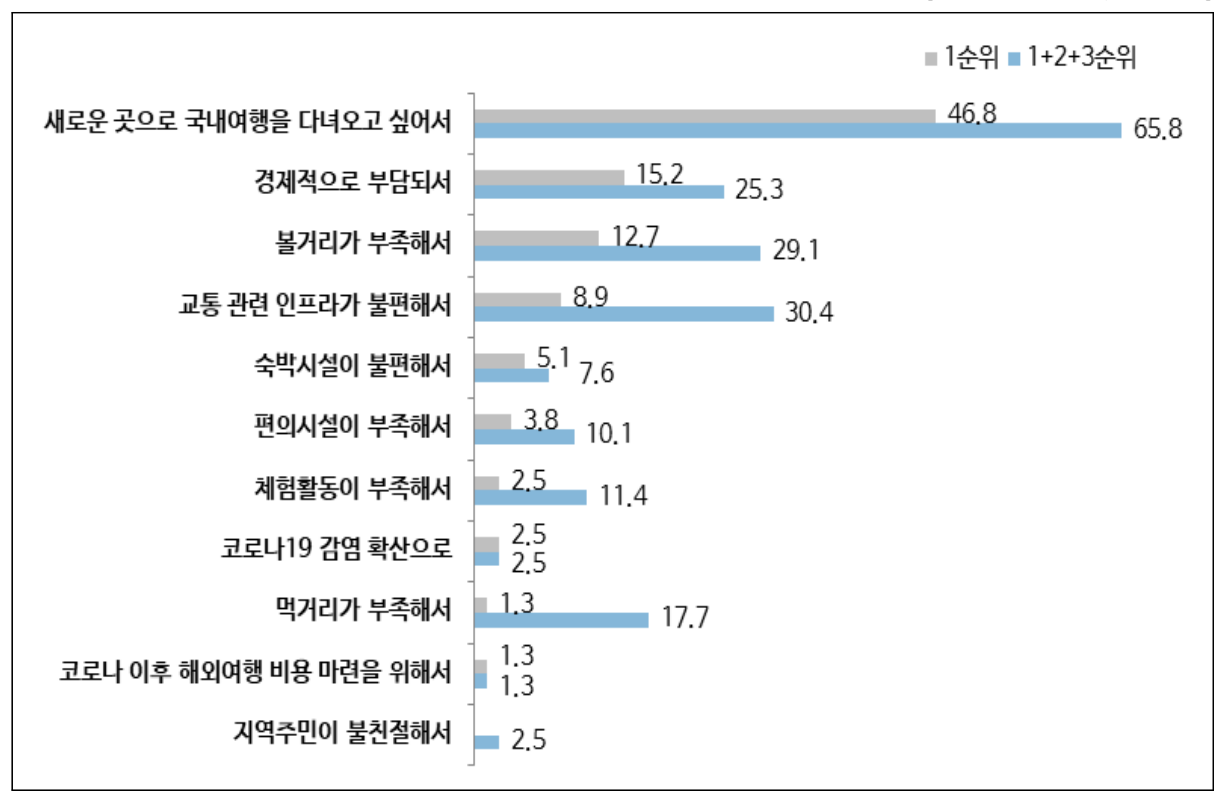

[그림 3-25] 재방문 의향 있는 이유

[재방문 의향 있음, 단위: \%]

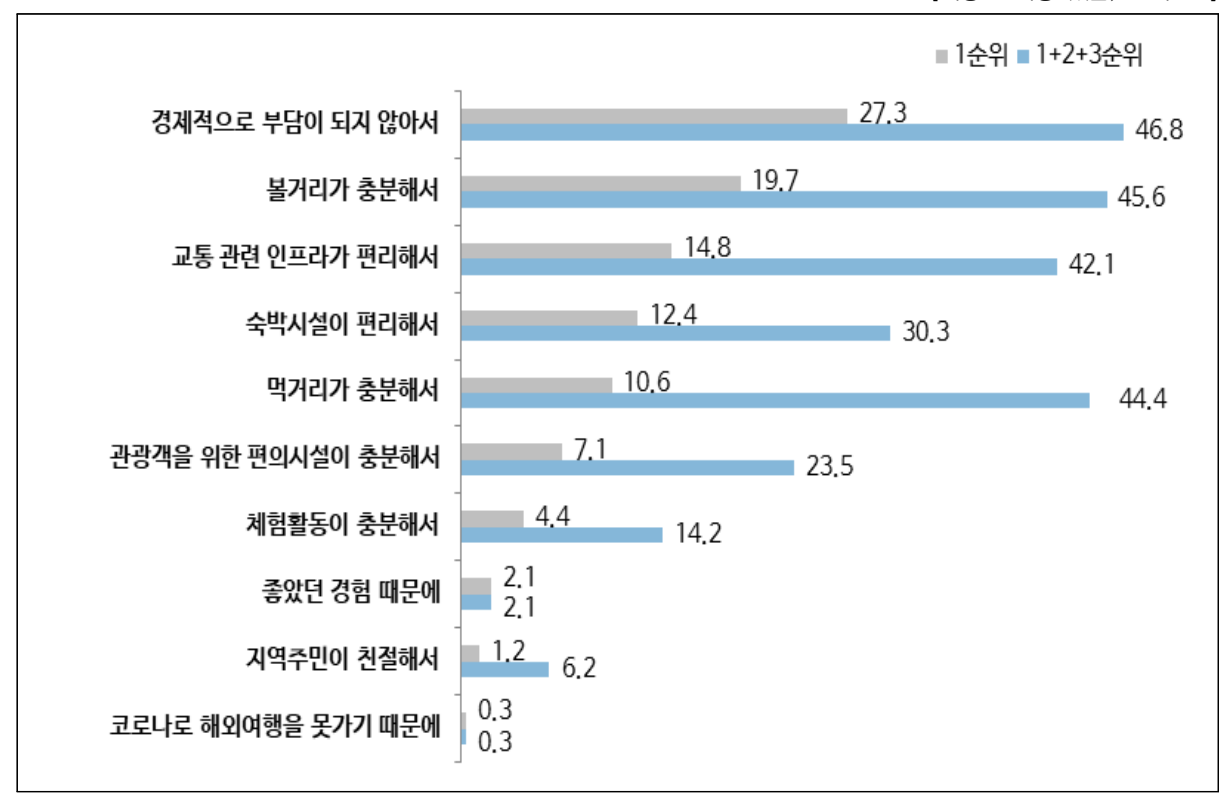




\section{다. 국내여행 평가 및 개선사항}

\section{1) 국내여행 평가}

2019년 1월 1일 이후 경험한 국내여행을 바탕으로 국내여행에 대해 평가하였을 때, '청년(및 동반자)에게 국내여행은 안전하다'에 동의하는 비율이 가장 높게 나타났으며, '여행하는데 다른 관광객들이 시선이 불편하다'(18.9\%)에 동의하는 비율이 가장 낮았다.

[그림 3-26] 국내여행 평가(긍정 응답 비율)

[전체, 단위: \%]

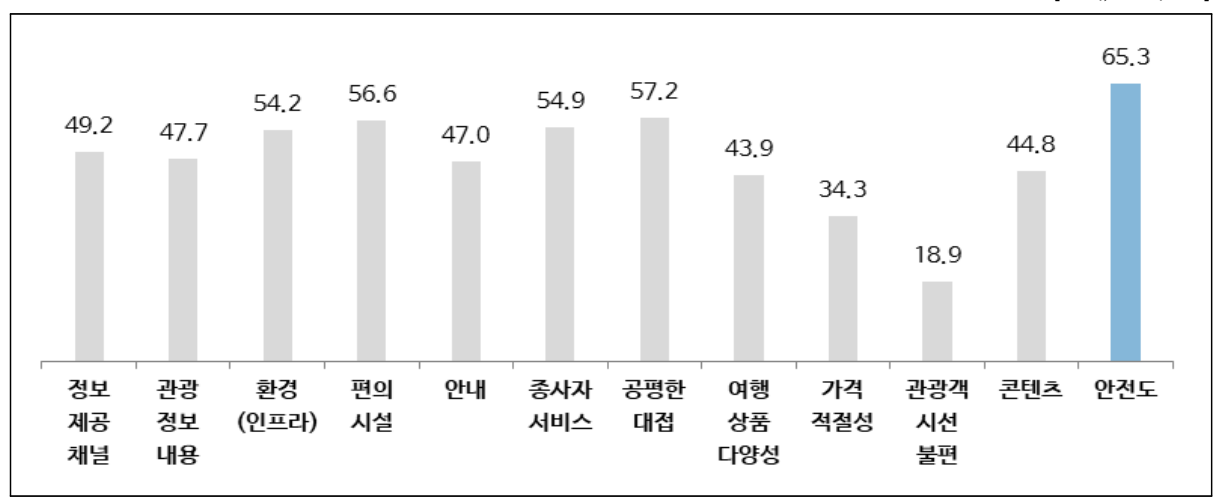

2) 개선사항 중요도

청년들의 국내여행 활성화를 위한 개선사항의 중요도를 물었을 때, '상품개발/개 선'(75.9\%), '인프라 구축'(75.1\%), '서비스 개선'(74.7\%) 등이 높게 나타났다.

[그림 3-27] 개선사항 중요도(긍정 응답 비율)

[전체, 단위: \%]

\begin{tabular}{|c|c|c|c|c|}
\hline & & 75.1 & 74.7 & 75.9 \\
\hline 64.3 & 67.1 & & & \\
\hline 관광저변 & 정보제공 & 인프라 & 서비스 & 상품개발/ \\
\hline 확대 & 확대 & 구축 & 개선 & 개선 \\
\hline
\end{tabular}




\section{3) 개선 주체 역할 중요도}

청년의 국내여행 활성화를 위한 개선사항에 있어, 공공과 민간 중 어느 쪽의 역할이 중요한지 물었을 때, '서비스 개선'(공공 $25.9 \%$, 민간 $48.1 \%$ )을 제외한 모든 항목에서 공공의 역할이 더 중요한 것으로 나타났다.

[그림 3-28] 개선 주체 역할 중요도(공공/민간 응답 비율)

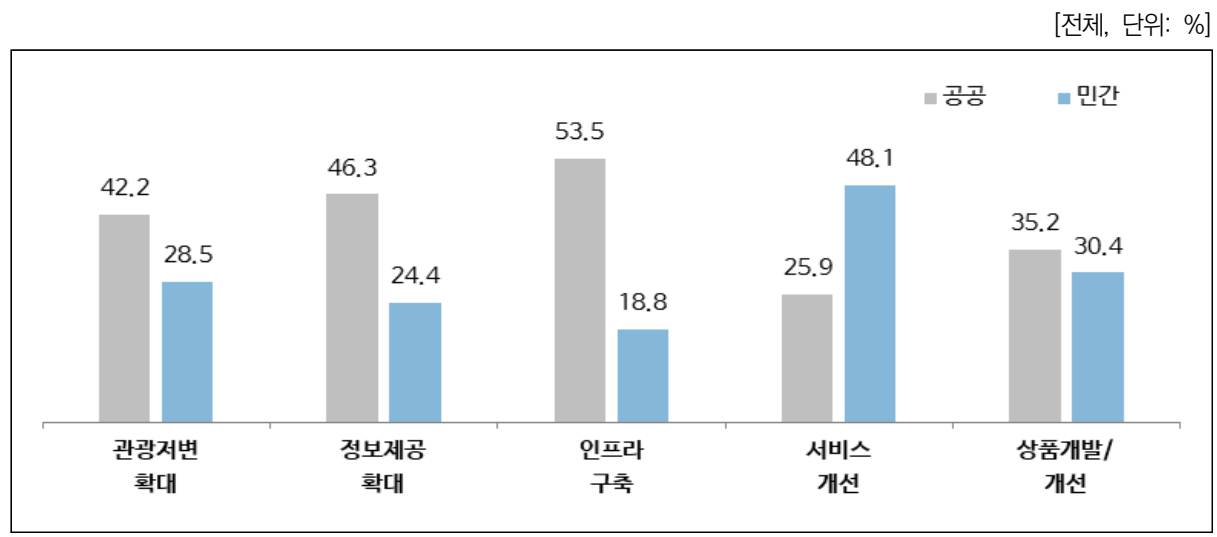

\section{4) 추진 필요 정책}

청년의 국내여행 활성화를 위해 정부가 추진해야 할 정책으로는 '근로자 휴가지원사 업 확대'(1순위 $21.6 \%, 1+2$ 순위 $33.0 \%$ )와 '국내 관광지 바가지요금 개선'(1순위 $16.5 \%, 1+2$ 순위 $33.4 \%)$ 이 가장 높은 것으로 나타났으며, '유연 근무제 확대 시행' $(1+2$ 순위 30.7\%), '지역 관광지 대중교통 접근성 개선'(1+2순위 23.8\%) 또한 상위로 응답되 었다. '근로자 휴가지원사업 확대'와 '유연 근무제 확대 시행'에 대한 선호는 특히 직장 인에게서 높은 것으로가 높은 것으로 나타났으며, 전체적으로 높은 우선순위로 응답되지 는 않았지만 대학(원)생은 ‘대학(원)생 여행경비 지원', 자녀동반 가구에서는 '유아동반 관광객 편의시설 확충'에 대한 응답이 상대적으로 높았다. 
[그림 3-29] 추진 필요 정책

[전체, 단위: \%]

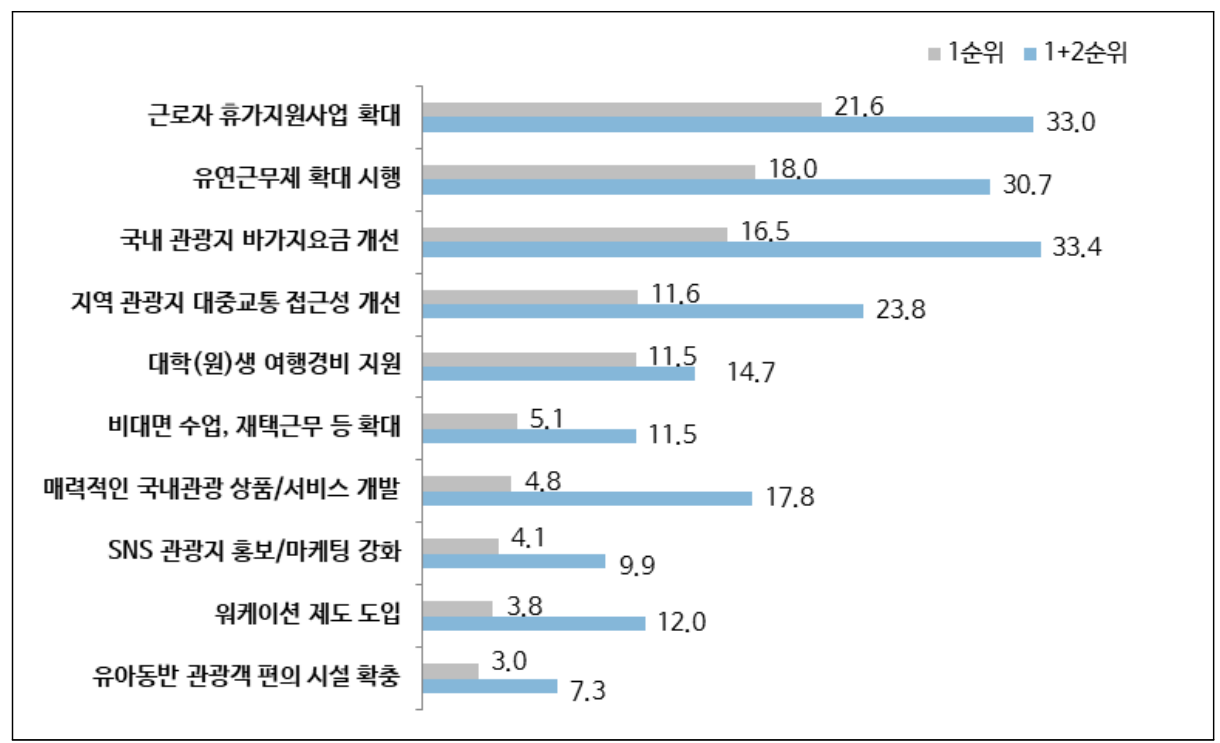

\section{3. 소결}

본 절에서는 국민여행조사 원자료 분석 결과 및 표적집단면접 조사를 통해 드러난 청 년층의 관광 인식을 바탕으로 보다 깊이 있는 청년층의 국내관광 특성을 파악하기 위한 온라인 조사를 수행하였다.

다만 본 조사에서는 응답자의 명확한 답변을 이끌어내기 위해 가장 최근에 다녀온 국 내여행 경험(2019년 이후)을 기준으로 답변하도록 하였기 때문에 본 조사의 결과는 특 정 기간 동안의 총량으로서의 의미를 갖지는 않으며, 청년층의 특성을 파악하기 위한 목적으로 활용되어야 할 것이다. 조사를 통해 청년층의 국내관광 특성은 다음과 같이 나타난다.

\section{가. 국내여행 특성}

조사결과 응답자는 대부분은 숙박여행(73.6\%)의 경험을 바탕으로 조사에 응답하였다. 청년층이 숙박여행시 주로 이용한 숙박시설은 호텔 및 펜션(69.4\%)인 것으로 나타났으 
며, 숙박시설 예약 시 야놀자, 호텔스닷컴 등의 숙박예약 플랫폼(58.0\%)을 가장 빈번히 이용하고 있었다. 또한 숙박시설 선택 시에는 비용/가격 (85.2\%), 위생(66.2\%) 등을 가 장 많이 고려하는 것으로 확인되었다.

조사 대상 청년층의 국내여행 목적지는 강원, 제주, 부산 순으로 나타났는데 전통적인 국내여행 목적지와 유사함을 확인할 수 있었다. 여행목적지를 선택할 때에는 접근성 (40.1\%)과 지역만이 갖고 있는 고유 콘텐츠(39.5\%)를 가장 우선적으로 고려하는 것으로 조사되었으나, 전망, 사진촬영 때문에(30.2\%), 가고 싶은 맛집이 있어서(29.8\%) 등 또한 높은 우선 순위로 고려되었다.

청년층의 국내여행 주 동반자는 친구/연인(55.3\%)으로 나타났으며, 혼자 여행을 하는 비율도 $10 \%$ 이상으로 청년층만의 특징적인 부분으로 이해할 수 있다. 청년층의 $68.7 \%$ 는 국내여행 시 스스로 여행경비를 마련하고 있었는데, 경제활동을 하지 않는 청년층에서는 부모/친척 등으로부터 여행경비를 지원 받는 경우가 상대적으로 높은 것으로 나타났다.

청년층의 $89.8 \%$ 는 국내여행 시, 대중교통을 이용하고 있으며, 대중교통을 이용하는 주된 이유로는 빠르고 쉽게 이동(44.8\%)할 수 있다는 장점과 자가용/렌터카와 비교하여 경제적으로 이용할 수 있는 점을(29.7\%)을 꼽고 있었다. 한편, 자가용/렌터카를 이용하 는 비율도 $70.0 \%$ 로 높게 나타났는데, 이용 이유로는 빠르고 쉽게 이동(56.7\%)할 수 있 다는 점과 더불어 자유로운 여행(33.6\%)이 가능하다는 점을 높게 꼽았다.

청년층 10 명 중 6 명은 다녀온 여행과 관련한 정보나 후기를 온라인 매체에 공유하고 있었으며, 페이스북, 인스타그램 등에서 공유 가능한 사진과 해시태그로 구성된 SNS콘 텐츠(70.6\%)의 형태를 가장 선호하는 것으로 타나났다.

\section{나. 국내여행 제약}

청년층의 국내여행 제약요인으로는 여행할 시간이 없다(23.2\%), 관광 인프라가 부족 하다(18.1\%), 경제적 여유가 없다(17.8\%), 정보가 부족하다(15.4\%)가 주된 요인으로 꼽 혔고, 안전하지 않다(5.7\%)는 가장 낮은 것으로 나타났다.

시간이 없는 이유는 휴가를 내기 어려운 직장 분위기(40.9\%)를 첫 손에 꼽았으며, 불 편한 관광 인프라는 여행목적지 내 교통수단(63.0\%), 비용부담이 큰 항목으로는 숙박비 $(88.8 \%)$ 가 가장 높았다. 


\section{다. 국내여행 평가 및 개선사항}

청년층의 과반 이상은 국내여행에 대해 안전하고(65.3\%), 다른 손님과 공평하게 대접 받으며(57.2\%), 편의시설(56.6\%), 관광 종사자의 서비스(54.9\%), 여행 인프라(54.2\%) 가 적절하다고 평가한 반면, 가격(34.3\%), 여행상품 구성(43.9\%), 콘텐츠(44.8\%)에 대 해서는 상대적으로 낮은 평가를 하였다.

청년층의 국내여행 활성화를 위한 개선 요인으로 상품개발(75.9\%), 서비스(74.7\%), 인프라(75.1\%)가 상대적으로 높았고, 개선 주체로는 인프라 구축은 공공, 서비스 및 상 품개발 개선은 민간을 높게 꼽았다.

한편, 청년층의 국내여행 활성화를 위한 정부 추진 정책은 바가지 요금 개선(33.4\%), 근로자 휴가지원사업 확대(33.0\%), 주52시간 근무제 등 유연근무제 확대 시행(30.7\%) 이 30\% 이상을 상회하였으나, 세분집단에 따라 '대학(원)생 여행경비 지원', '유아동반 관광객 편의시설 확충 등의 의견이 제시되기도 하였다. 


\section{제4절 종합 분석}

제 3 장에서는 청년층의 국내관광 특성을 분석하고 청년관광 및 국내관광 활성화 방안 수립의 근거가 되는 기초자료를 제시하고자 하였다. 이를 위해 일차적으로 국민여행조사 원자료를 분석하여 청년층의 국내관광 총량 변화와 행태 등 국내관광 실태를 검토하였 으며, 두 번째 단계에서는 청년관광 표적집단면접 조사로서 청년층 내면의 관광인식과 선호 세분집단별 특성을 살펴보았다. 그리고 마지막 단계에서는 청년층 국내관광 특성에 대한 온라인 조사를 통해 기존 국가승인통계를 통해 확인할 수 없는 국내관광 행태에 대한 추가 조사, 국내관광 제약요인, 국내관광에 대한 평가 및 개선사항을 검토하여 청 년층의 국내관광 확대를 위한 정책방향 설정의 준거를 마련하였다.

\section{가. 국내관광 시장에서 청년층의 의미}

청년층은 해외여행을 선호하나 전체적인 여행 참여 빈도가 높고 국내관광 시장을 주 도하는 계층으로 전체 국민과 비교해 1 인 평균 여행 횟수, 1 인 평균 여행 일수, 1 인 평균 여행지 지출 등이 높은 것으로 나타나고 있으며, 코로나19 확산의 영향으로 국내관광 활동의 크게 위축된 상황에서도, 관광여행 중심의 국내관광 활동을 지속적으로 이어가는 등 코로나19 이후 국내관광 시장 회복을 주도해 나갈 핵심 계층으로 평가할 수 있다.

특히, 청년층 내에서도 여성, 30대 이상, 전업주부, 주5일 근무제 시행 사업장의 직장 인, 기혼 및 자녀동반 가구 등은 국내관광 활동을 활발히 영위하고 있는 세분집단으로 확인되었다. 다만, 코로나 19 이후 경제활동, 직업, 가구형태 등에 따른 세분집단별로 국 내관광 활동에 있어서 차별적인 행태가 드러나고 있으며, 특히 경제활동을 영위하지 않 는 청년층의 경우 국내여행 향유 경험의 격차가 확대되고 있는 것으로 나타나 향후 국내 관광 활성화를 위한 정책방향 설정 시에는 청년층 내 세분집단별 차이를 면밀히 고려하 여야 할 것이다. 


\section{나. 청년층의 국내관광 행태}

청년층의 국내관광 행태는 일반적으로 전체 국민과 유사한 것으로 확인되었으나 여행 정보 획득 경로, 동반객 수 및 유형, 여행지 활동, 이동 수단, 여행상품의 구매 행동 등에 서 청년층만의 독특한 특성이 나타난다.

대표적으로 여행정보 획득 경로에 있어서 청년층은 '인터넷 사이트/모바일 앱'에 대한 활용도가 높으며, 포털사이트, SNS, 동영상 사이트에 대한 선호가 높은 것으로 확인되었 다. 또한 페이스북, 인스타그램 등에서 공유할 수 있는 사진과 해시태그로 구성된 SNS 콘텐츠와 같이 특정 유형의 정보에 대한 수요가 높으며, 다수의 청년층이 국내여행 후 관련 정보를 디지털 매체를 통해 공유(재생산) 하는 등 일반적인 국민들의 정보활용 행 태와 차별화 되는 특성을 보인다.

또한 청년층은 여행지 활동 시 자연 및 풍경 감상과 같이 일반적으로 선호되는 활동뿐 만 아니라 '시티투어', '테마파크, 놀이시설, 동/식물원 방문' 등 체험활동에 보다 적극적 으로 참여하고 있었다. 심층면접조사 실시 결과 청년층은 이러한 체험활동을 특정 관광 목적지를 방문하는 핵심 동기로 꼽기도 하였으며, 지역에 대한 주기적인 재방문 이유로 설명하였다.

청년층의 주요 이동 수단은 자가용으로 나타났으나, 주로 경제적인 요인에 의해 '고속 /시외/시내버스', '지하철' '철도' 등 대중교통을 이용률이 상대적으로 높았다. 청년층 역시 빠르고 쉽게 이동할 수 있다는 점과 더불어 자유로운 여행이 가능하다는 장점 때문 에 자가용(또는 렌터카)의 이용을 선호하고 있었으며, 2020년 이후에는 코로나19의 영 향으로 안전한 여행을 위한 자가용 이용이 증가하고 있다.

청년층은 여행상품 이용 시 전체 국민대비 높은 사전 예약률을 보였으며 '숙박시설'에 대한 예약이 대부분을 차지하였다. 청년층은 숙박시설 예약 시 야놀자, 호텔스닷컴 등의 숙박예약 플랫폼을 가장 빈번히 이용하고 있었으며, 숙박시설 선택 시에는 비용/가격 , 위생 등을 주로 고려하고 있다. 특히 숙박과 관련하여 여행비 가운데 숙박비에 대한 부 담을 가장 크게 느끼는 것으로 나타났다.

이 외에도 청년층의 전체 국민과 비교해 국내여행 시 동반자 수가 다소 적은 것으로 확인되며, 주로 '친구/연인', '가족' 등 개인적인 관계 내에서 동반 여행이 이루어지는 것으로 나타났다. 또한 혼자 여행하는 비율도 상당수를 차지하고 있었는데 이 또한 청년 
층 고요의 특성으로 이해할 수 있다.

\section{다. 청년층의 국내관광 제약}

청년층의 국내관광 제약요인으로는 여행할 시간이의 부족과 관광 인프라가 부족, 경 제적 여유부족 등이 주된 요인으로 꼽혔다. 특히 직장인의 경우 시간이 없는 이유는 휴 가를 내기 어려운 직장 분위기를 첫 손에 꼽았으며, 대학(원)생은 취업/학업 등에 대한 부담을 원인으로 지목하였다. 불편한 관광 인프라로는 여행목적지 내 교통수단을 가장 불편하다고 응답하였는데 이는 청년층 외에도 전반적으로 국내 지역관광에 대해 지적되 고 있는 문제 중 하나이다. 비용부담과 관련해서는 숙박비에 대한 부담을 가장 크게 느 끼고 있었는데 경제활동을 하지 않는 청년층의 경우 부모/친척 등으로부터 여행경비를 지원 받는 경우가 상대적으로 높았던 점을 고려할 때 청년층의 국내관광을 활성화하기 위한 경제적 유인의 제공이 고려되어야 할 필요성이 있다.

\section{라. 국내여행 평가 및 개선사항}

청년층의 과반 이상은 국내여행에 대해 안전하고, 다른 손님과 공평하게 대접 받으며, 편의시설, 관광 종사자의 서비스, 여행 인프라가 적절하다고 평가한 반면, 가격, 여행상 품 구성, 콘텐츠에 대해서는 상대적으로 낮은 평가를 하였다.

청년층은 국내여행 활성화를 위한 개선 요인으로 상품개발, 서비스, 인프라 등에 대한 개선을 우선순위로 꼽았고, 개선의 주체로는 인프라 구축은 공공, 서비스 및 상품개발 개선은 민간을 선정하였다.

한편, 청년층의 국내여행 활성화를 위해 필요한 정부 추진 정책은 바가지 요금 개선, 근로자 휴가지원사업 확대, 주52시간 근무제 등 유연근무제 확대 시행 등이 우선순위에 선정되었으나 대학(원)생은 ‘대학(원)생 여행경비 지원', 자녀동반 가구에서는 ‘유아동반 관광객 편의시설 확충에 대한 선호가 높아 정부 정책 방향 설정 시 생애주기별 특성을 고려한 정책방안을 모색할 필요성이 있다. 
〈표 3-45〉 청년층 국내여행 특성 종합 분석

\begin{tabular}{|c|c|c|c|}
\hline \multicolumn{2}{|r|}{ 구분 } & 전체 & 청년층 \\
\hline \multirow{5}{*}{$\begin{array}{l}\text { 여 } \\
\text { 행 } \\
\text { 총 } \\
\text { 량 }\end{array}$} & 종합 & \multicolumn{2}{|c|}{$\begin{array}{l}\text { - 청년층은 전체 국민과 비교하여 } 1 \text { 인 평균 여행 횟수, } 1 \text { 인 평균 여행 일수, } 1 \text { 인 평균 여행지 } \\
\text { 지출액 등 주요 국내관광 총량에서 높아 국내관광 시장을 주도하는 계층 }\end{array}$} \\
\hline & 경험률 & $92.4 \%$ & $91.2 \%$ \\
\hline & 여행 횟수 & 7.61천 회 & 8.23천 회 \\
\hline & 여행 일수 & 12.94천 일 & 14.17천 일 \\
\hline & 여행 지출 & 976천 원 & 1,118 천 원 \\
\hline \multirow{5}{*}{$\begin{array}{l}\text { 앵 } \\
\text { 태 }\end{array}$} & 종합 & \multicolumn{2}{|c|}{$\begin{array}{l}\text { - 청년층의 주요 국내관광 행태는 전체 국민과 유사한 것으로 나타나나, 여행정보 획득경로, } \\
\text { 동반자 수 및 유형, 여행지 활동, 이동 수단, 여행상품 구매 행동 등에서 차이 관찰 }\end{array}$} \\
\hline & 여행정보 & - 주변인 및 과거 방문경험에 의존 & $\begin{array}{l}\text { - 주변인 및 과거 방문경험 외에 상대적으로 } \\
\text { 인터넷사이트/모바일 앱의 이용률이 높음 }\end{array}$ \\
\hline & 동반자 & $\begin{array}{l}\text { - 2019년 기준 평균 동반자 수는 } 4.3 \text { 명, 주요 } \\
\text { 동반자는 가족(55.1\%) }\end{array}$ & $\begin{array}{l}\text { - 2019년 기준 평균 동반자 수는 4.2명, 주요 } \\
\text { 동반자는 친구/연인(69.5\%) }\end{array}$ \\
\hline & $\begin{array}{l}\text { 여행지 } \\
\text { 활동 }\end{array}$ & $\begin{array}{l}\text { - 주요 여행지 활동은 자연 및 풍경 감상, 휴 } \\
\text { 식/휴양 등 }\end{array}$ & $\begin{array}{l}\text { - 자연 및 풍경 감상, 휴식/휴양 외에 테마파 } \\
\text { 크, 유원지, 동/식물원 방문, 야외 위락 활동 } \\
\text { 등 체험활동 참여 활발 }\end{array}$ \\
\hline & 이동수단 & - 국내관광 시 주요 이동수단은 자가용 & $\begin{array}{l}\text { - 청년층은 자가용 외 상대적으로 대중교통 이 } \\
\text { 용 비중 높음 }\end{array}$ \\
\hline \multirow{4}{*}{$\begin{array}{l}\text { 코 } \\
\text { 로 } \\
\text { 나 } \\
1 \\
9 \\
\text { 영 } \\
\text { 향 }\end{array}$} & 종합 & \multicolumn{2}{|c|}{$\begin{array}{l}\text { - 코로나19 확산 이후에도 청년층은 전체 국민 대비 관광여행 중심 국내관광 활동을 활발히 } \\
\text { 영위하고 있는 것으로 나타났으나, 코로나19의 영향으로 국내관광 행태의 변화가 나타남 }\end{array}$} \\
\hline & 여행총량 & $\begin{array}{l}\text { - 코로나19의 영향으로 주요 국내관광 총량이 } \\
\text { 큰 폭으로 감소함 }\end{array}$ & $\begin{array}{l}\text { - 코로나19의 영향으로 주요 국내관광 총량이 } \\
\text { 감소하였으나, 전체 국민 대비 작은 감소폭 } \\
\text { - 여행 경험률은 2019년 대비 소폭 증가함 }\end{array}$ \\
\hline & $\begin{array}{c}\text { 주요 } \\
\text { 여행행태 }\end{array}$ & $\begin{array}{l}\text { - (이동수단) 불특정 다수에 대한 접촉을 피할 } \\
\text { 수 있는 자가용 이용 증가 } \\
\text { - (국내 여행상품 사전예약) 이용률 감소 } \\
\text { - (동반자) 여행시 동반자 수 감소, 주요 동반 } \\
\text { 자 유형은 가족, 친구/연인 등 } \\
\text { - (숙박시설) 펜션, 가족/친지집 이용 증가 }\end{array}$ & $\begin{array}{l}\text { - (이동수단) 대중교통 이용이 감소하고 자가 } \\
\text { 용 이용이 큰 폭으로 증가함 } \\
\text { - (국내 여행상품 사전예약) 이용률 소폭 감소 } \\
\text { - (동반자) 여행시 동반자 수 소폭 감소, 주요 } \\
\text { 동반자 유형은 친구/연인, 가족 여행 큰 폭 } \\
\text { 감소 } \\
\text { - (숙박시설) 호텔 이용 비중의 상대적 증가 }\end{array}$ \\
\hline & 제약요인 & \multicolumn{2}{|c|}{ - 공통적으로 코로나19 감염에 대한 우려가 국내여행의 최대 제약요인으로 나타남 } \\
\hline & 종합 & \multicolumn{2}{|c|}{$\begin{array}{l}\text { - 청년층 내 경제활동 여부, 결혼, 출산 등 생애주기에 따른 세분집단이 존재하며 일부 국내관 } \\
\text { 광 행태 및 코로나19 영향에서 세분집단별 차이가 나타나고 있음 }\end{array}$} \\
\hline $\begin{array}{l}\text { 세 } \\
\text { 분 } \\
\text { 집 } \\
\text { 단 } \\
\text { 별 }\end{array}$ & $\begin{array}{l}\text { 비경제활 } \\
\text { 동 계층 } \\
\text { (대학(원) } \\
\text { 생, 무직자 } \\
\text { 등) }\end{array}$ & \multicolumn{2}{|c|}{$\begin{array}{l}\text { - 경제적 제약으로 인해 청년층 내에서 국내관광 활동이 상대적으로 소극적인 계층이며, 여행 } \\
\text { 시 부모/친척 등에 대한 경제적 의존도가 높은 것으로 나타남 } \\
\text { - 코로나19 확산 이후에는 경제적 어려움으로 인해 국내관광에 향유 격차가 확대되었음 } \\
\text { - 반면 일부 대학(원)생은 비대면 수업의 확대로 국내관광 향유 여건이 개선된 것으로 확인 }\end{array}$} \\
\hline 슥 & $\begin{array}{l}\text { 기혼 } \\
\text { 자녀동반 } \\
\text { 가구 }\end{array}$ & \multicolumn{2}{|c|}{$\begin{array}{l}\text { - 30대 이상, 전업주부, 경제활동 계층, 기혼 자녀동반 가구는 청년층 내에서도 국내관광 활동 } \\
\text { 을 활발히 영위하고 있는 집단임 } \\
\text { - 기혼 자녀동반 가구는 국내관광 목적지 및 숙박시설 선택시 동반자녀를 위한 편의시설과 안 } \\
\text { 전을 최우선으로 고려 } \\
\text { - 코로나19 확산 후에는 감염병 위험에 대한 높은 민감도로 인해 국내관광 활동이 크게 위축됨 }\end{array}$} \\
\hline
\end{tabular}


국내관광 활성화를 위한 청년관광 실태 분석 및 정책방안

제4장

청년관광 정책현황 및 사례 



\section{제1절 우리나라 청년관광 정책과 사례}

\section{1. 청년관광 정책의 배경과 흐름}

\section{가. 우리나라 청년정책 동향}

우리나라 청년정책은 청년들이 당면한 가장 큰 어려움인 취업 문제를 감안하여 '일자 리 창출' 에 방점을 두고 시작되었다. 박근혜 정부에서 대통령 직속으로 설치되었던 〈청 년위원회>에서는 (1) 청년 일자리 창출, (2) 청년발전 정책추진 (3) 소통과 인재양성을 위 한 정책사업의 3 대 기능을 제시하였지만, 실질적 목표는 고용창출에 놓여 있었다.

〈표 4-1〉 청년위원회(2013 2017) 주요 기능

\begin{tabular}{c|l}
\hline 구분 & \multicolumn{1}{c}{ 주요 내용 } \\
\hline $\begin{array}{c}\text { 청년일자리 } \\
\text { 창출 }\end{array}$ & $\begin{array}{l}\text { ・ 공공·민간 분야 일자리 발굴, 청년창업 생태계 조성 } \\
\text { • 청년 일자리 문제 범부처적 해결, 청년 해외 진출(K-move) 지원 }\end{array}$ \\
\hline 청년발전 & $\begin{array}{l}\text { ・ 부처별 분산된 청년정책 조율, 청년관련 국정과제 이행 지원 } \\
\text { - } 2030 \text { 정책 참여단 운영 통한 현장 취재 및 소통 }\end{array}$ \\
\hline 소통인재 양성 & $\begin{array}{l}\text { - 온·오프라인 소통, 청춘순례(청년멘토 · 전문가 캠프), 청년버스(찾아가는 맞춤형 상 } \\
\text { 담서비스), 청년포털(원스톱 청년 지원정보 제공), 인재양성 프로그램 등 }\end{array}$ \\
\hline
\end{tabular}

자료: 연구자 정리

정부가 청년이 당면한 문제들 중에서 일자리 창출에 신경을 쓴 이유는 청년층의 실업 률이 우리나라 평균 실업율의 두 배를 훨씬 상회하기 때문이다(〈표 4-2〉 참조). 
〈표 4-2〉 우리나라 고용현황 추이(2015 2020)

[단위: 만 명, \%]

\begin{tabular}{c|c|c|c|c|c|c}
\hline 구분 & 2015 & 2016 & 2017 & 2018 & 2019 & 2020 \\
\hline 취업자 증감 & 28.1 & 23.1 & 31.6 & 9.7 & 30.1 & -21.8 \\
\hline 실업자 & 97.6 & 100.9 & 102.3 & 107.3 & 106.3 & 110.8 \\
\hline 실업률(\%) & 3.6 & 3.7 & 3.7 & 3.8 & 3.8 & 4.0 \\
\hline 청년실업자 & 38.9 & 42.6 & 42.6 & 40.8 & 38.6 & 37.0 \\
\hline 청년실업률(\%) & 9.1 & 9.8 & 9.8 & 9.5 & 8.9 & 9.0 \\
\hline
\end{tabular}

자료: 통계청 〈경제활동인구조사〉

주) 청년실업자 및 청년실업률 연령 기준: 15 29세

문재인 정부에서는 이전(以前) 박근혜 정부에서 설치한 〈청년위원회〉를 폐지하고 대 통령 직속에 일자리 전반을 담당하는 〈일자리위원회〉가 설치하였다. 그리고 청년문제를 담당하는 종합 위원회는 제정된「청년기본법」에 따라 국무총리 산하인 국무조정실에 〈청년정책조정위원회〉 가 2020년에 설치되었다.7)「청년기본법」에서는 〈청년정책조정 위원회〉의 설치 외에 〈청년정책기본계획〉 수립 및 시행에 관해서도 명시하고 국무총리 가 매 5년마다 청년정책 기본계획을 수립토록 하고 있으며, 기본방향과 분야별 시책, 청 년참여 확대방안 등을 담도록 하고 있다.

이에 따라 문재인 정부는 〈제 1 차 청년정책 기본계획〉을 수립하여 발표하였는데 이 계 획에서는 기존에 일자리에 치우쳐 있던 청년 정책의 범위를 다른 분야로 확장하여 '(1) 일자리(94개 과제) (2) 주거(24개 과제) (3) 교육 (83개 과제) (4) 복지·문화 (37개 과제)

(5) 참여·권리(32개 과제)' 의 5대 분야 총 270개 세부 과제를 제시하였다.

이 계획은 청년정책의 범위를 일자리에서 청년의 삶 전반으로 확대시킨 최초의 종합 적 정책 시도라는 의의는 있지만, 여전히 세부 과제의 내용은 과반 이상이 청년의 창업 과 취업에 관련된 내용으로 구성되어 있다.

7) 청년기본법 제13조(청년정책조정위원회) “(1) 청년정책에 관한 주요 사항을 심의 · 조정하기 위하여 국무총 리 소속으로 청년정책조정위원회(이하 이 조에서 "위원회"라 한다)를 둔다." 
[그림 4-1] 〈제1차 청년정책 기본계획〉 개요

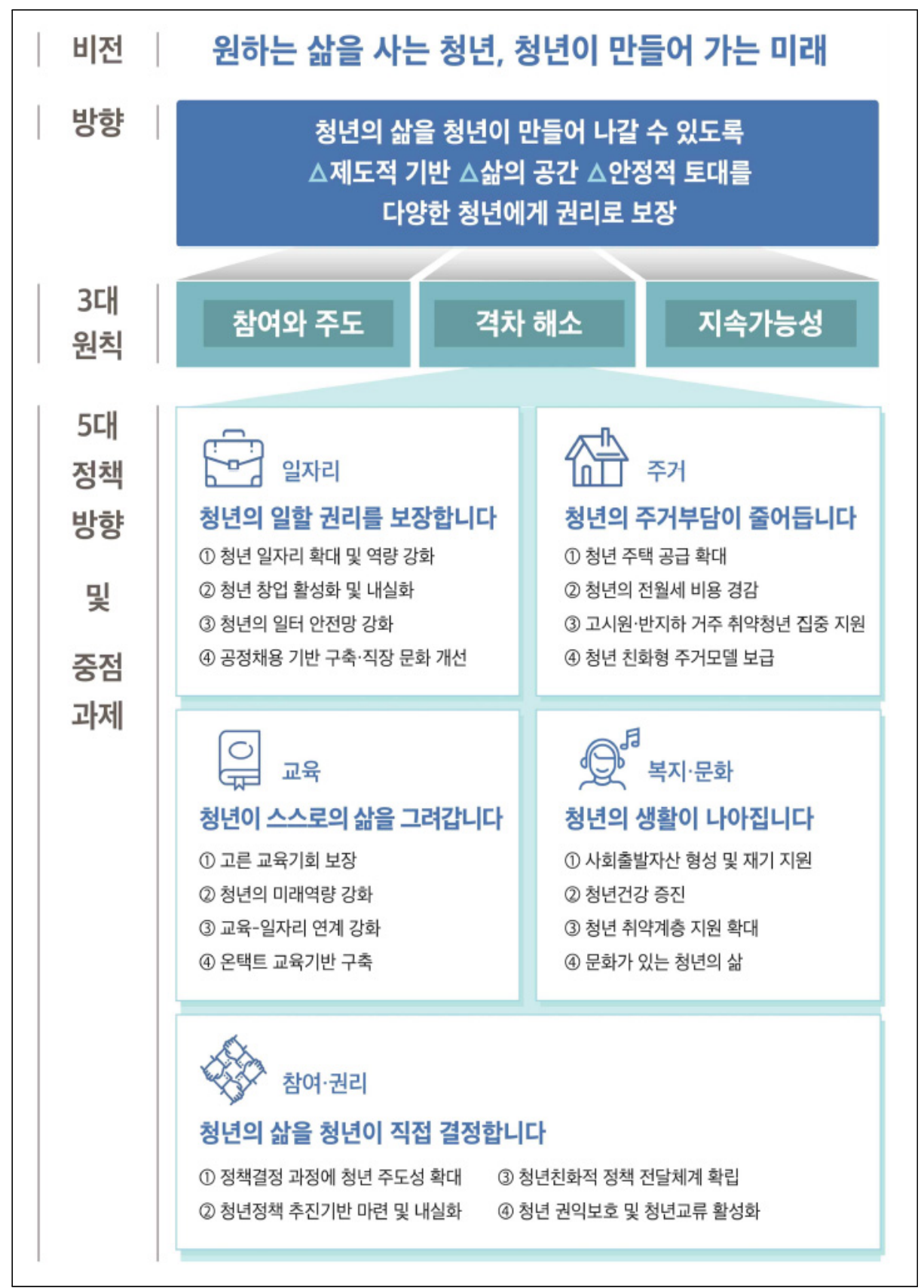

출처: 청년정책조정위원회(2020), 제 1 차 청년정책기본계획 


\section{나. 우리나라 청년관광 정책동향}

관광분야의 청년관광 정책동향도 우리나라 청년정책 기조와 유사하게 흘러왔다. 관광 분야의 청년관광 지원정책도 일자리 창출이라는 정부 중점과제에 동참하는 형태로 시작 되었다. 그러나 관광 분야는 서비스 산업이라는 특성으로 공공 분야 단기직 일자리 창출 이나 특정한 기술교육 아카데미 운영이 어려운 관계로 청년관광정책은 청년의 창업을 독려하는 방식을 채택하였다. 이러한 대표적 사업으로는 문화체육관광부의 관광벤처사 업, 관광두레사업, 청년 일 경험 지원 사업 등을 꼽을 수 있는데, 이들 사업에서 만 34세 미만 청년창업자에 대한 벤처 공모사업 선발 시 가점을 부여8)하거나 관광두레 청년 프 로듀서(PD)9) 제도의 운영을 통해 청년층의 사업 참여 확대 및 창업 기반을 독려하고자 노력했다. 또한 중앙부처가 아닌 지자체 차원에서 시행된 청년관광 정책의 경우도 역시 일자리 창출을 위하여 시행된 정책이 다수로 관광분야 청년 희망일자리사업(서울시), 청 년이 중심이 되는 원(原) 도심 특화관광 지원 사업(부산시), 관광 청년인턴 지원 사업(경 상북도)등이 있고 청년관광 전문가 양성 및 관련 일자리 창출, 지역관광 기업 지원을 목 적으로 시행되었다. 그러나 이러한 정책들은 모두 일자리 창출이라는 관점에서 시행된 사업이고 또한 해당 부처나 지자체의 핵심 사업이 아닌 정부의 청년 고용대책에 동참하 는 정도로 진행이 된 한계들을 가지고 있다.

한편 이러한 일자리 창출이라는 관점을 벗어나서 최근 국가차원의 청년종합계획 추진 에 따라 문화체육관광부에서 청년층의 문화 복지적 측면에서 관광 향유권 확대와 여행 수요 진작을 위한 사업 일부 진행하기 시작하였다. 그리고 중앙부처 이외 지자체에서는 관광객을 유치하고 지역경제를 활성화하기 위한 목적으로 관광객의 지역 내 관광비용을 보조하는 지원 사업을 전개하고 있으나, 그 대상이 청년층에 국한되지 않지만 지원 대상 선정 우대기준으로 저소득층이나 SNS 활용 여부 등을 병기하고 있어서 간접적으로 청년 관광 활동을 지원하는 효과를 불러일으킨다.

본 연구에서는 청년층의 국내관광 수요 진작이라는 측면에서 국내관광 활성화 관련 시례들에 대해 좀 더 구체적으로 살펴보겠다.

8) 문체부(사업주관:한국관광공사) 관광벤처사업 공모전에서 만 34세 미만 청년 창업자에게 가점 1점 부여

9) 〈관광두레〉 사업은 문체부가 지역주민 공동체 기반의 지속가능한 관광 사업체 창업 및 육성을 위하여 실행 하고 있는 사업인데, 본 사업에서 역시 청년관광 창업의 독려를 위하여 만 34세 미만 지원시 청년 관광두 레 PD 분야로 일정 비율을 선발함 


\section{2. 우리나라 청년관광 정책 시례}

\section{가. 문화체육관광부(한국관광공사) 정책사업}

문화체육관광부에서 현재 청년관광 활성화를 위하여 시행하고 있는 정책사업은 크게 세 가지로 청년관광 공모전(트래블리그), 청년층 갭 이어(Gap Year), 대학생 Youtube 기자단(트래블리더. move)로 사업주관은 한국관광공사에서 맡고 있다.

\section{1) 청년관광 공모전 (트래블리그)}

〈청년관광 공모전〉 정책 사업은 청년층의 국내여행 체험기회 확대, 여행수요견인 및 청년들이 여행코스를 기획하고 그 체험을 통해서 취향별 테마여행 문화를 확산하기 위 해 시행되고 있는 사업이다.

[그림 4-2] 청년관광 공모전 (트래블리그) 홍보 포스터

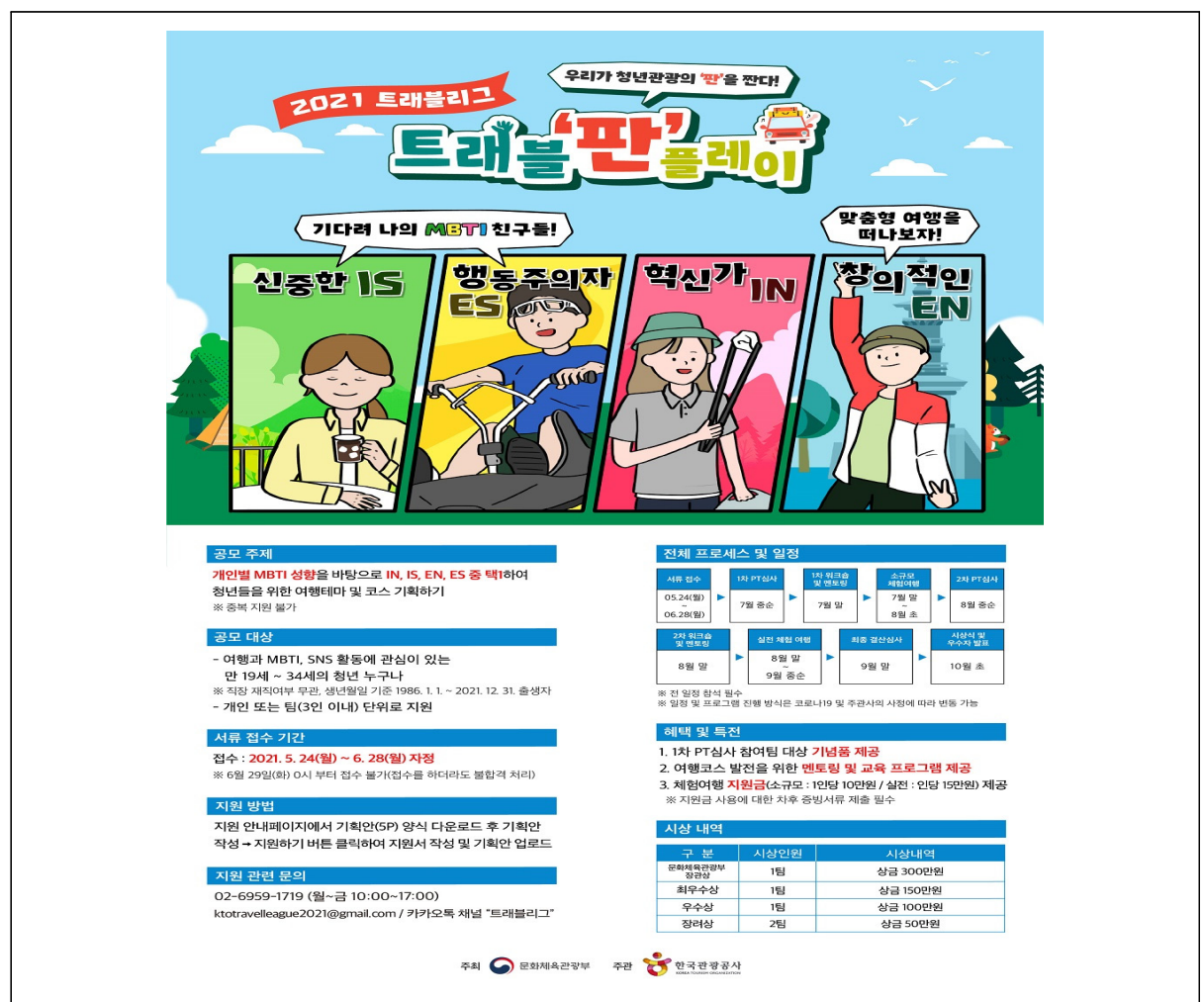

자료: 문화체육관광부\& 한국관광공사(2021) 보도자료 
동 사업은 ‘트래블 리그’ 라는 별칭처럼 단계적 오디션 방식을 통해 최종 결선팀을 가리는 특징이 있다.

[그림 4-3] 청년관광 공모전 (트래블리그) 진행 과정

\begin{tabular}{|c|c|c|c|}
\hline 서류접수 & 서류 심사 & $\begin{array}{l}\text { 1차 멘토링 및 } \\
\text { 소규모 여행 체험 }\end{array}$ & $\begin{array}{l}\text { 1차 } \mathrm{PT} \\
\text { (본선)심사 }\end{array}$ \\
\hline $\begin{array}{l}\text { 공모전 참가 } \\
\text { 지원서 접수 } \\
\text { * 지원서 형태: } \\
\text { 국내여행 코스 } \\
\text { 기획안 요약본 }\end{array}$ & $\begin{array}{c}\text { 지원서 검토 및 } \\
\text { 서류합격자 선발 } \\
\text { * 35개팀(약 100명) } \\
\text { 선발 예정 }\end{array}$ & $\begin{array}{c}\text { 기획안 코스 관련 } \\
\text { 팀별 멘토링 진행 } \\
\text { 및 소규모 여행 } \\
\text { 체험 실시 }\end{array}$ & $\begin{array}{c}\text { 1차 PT 발표 } \\
\text { 합격자 선발 } \\
\text { * 20개팀(약 } 60 \text { 명) } \\
\text { 선발 예정 }\end{array}$ \\
\hline $\begin{array}{l}\text { 2차 멘토링 및 } \\
\text { 소규모 여행 체험 }\end{array}$ & 2차 PT (본선)심사 & 실전여행 체험 & $\begin{array}{c}\text { 최종 PT 심사 및 } \\
\text { 우수팀 시상 }\end{array}$ \\
\hline $\begin{array}{c}\text { 특별미션 부여, } \\
\text { 2차 멘토링 및 } \\
\text { 소규모 여행 체험 } \\
\text { 실시 }\end{array}$ & $\begin{array}{c}\text { 2차 PT 발표 } \\
\text { 합격자 선발 } \\
\text { * 10개팀(약 } 30 \text { 명) } \\
\text { 선발예정 }\end{array}$ & $\begin{array}{c}\text { 실전여행 Tip 간단 } \\
\text { 교육 및 실전여행 } \\
\text { 체험 실시 }\end{array}$ & $\begin{array}{c}\text { 최종 PT 발표 및 } \\
\text { 우수팀 } \\
\text { (6개팀)시상 }\end{array}$ \\
\hline
\end{tabular}

자료: 한국관광공사 내부자료(2021)

또한 이 사업은 매해 특정한 공모 주제를 제시하여 각 주제에 맞춰 팀(1인가능)별로 여행코스를 구성하여 지원하게 하는데 첫해 사업의 경우 사회성 있는 주제인 로컬여행, 사회적 가치여행, 나만의 테마여행을 제시하였고, 둘째 해인 21년의 경우는 좀 더 쳥넌 층의 감성에 맞는 개인별 $\mathrm{MBTI}$ 성향(본인의 성향을 파악하는 심리검사 방법)을 공모 주제로 제시하였다.

2020 년 최종 사업결과는 결선진출 16 개 팀이 제안한 여행코스를 기초로 하여 가이드 북을 제작하였다([그림 4-4] 참조). 
[그림 4-4] 청년관광 공모전(트래블리그) 여행 가이드북 표지

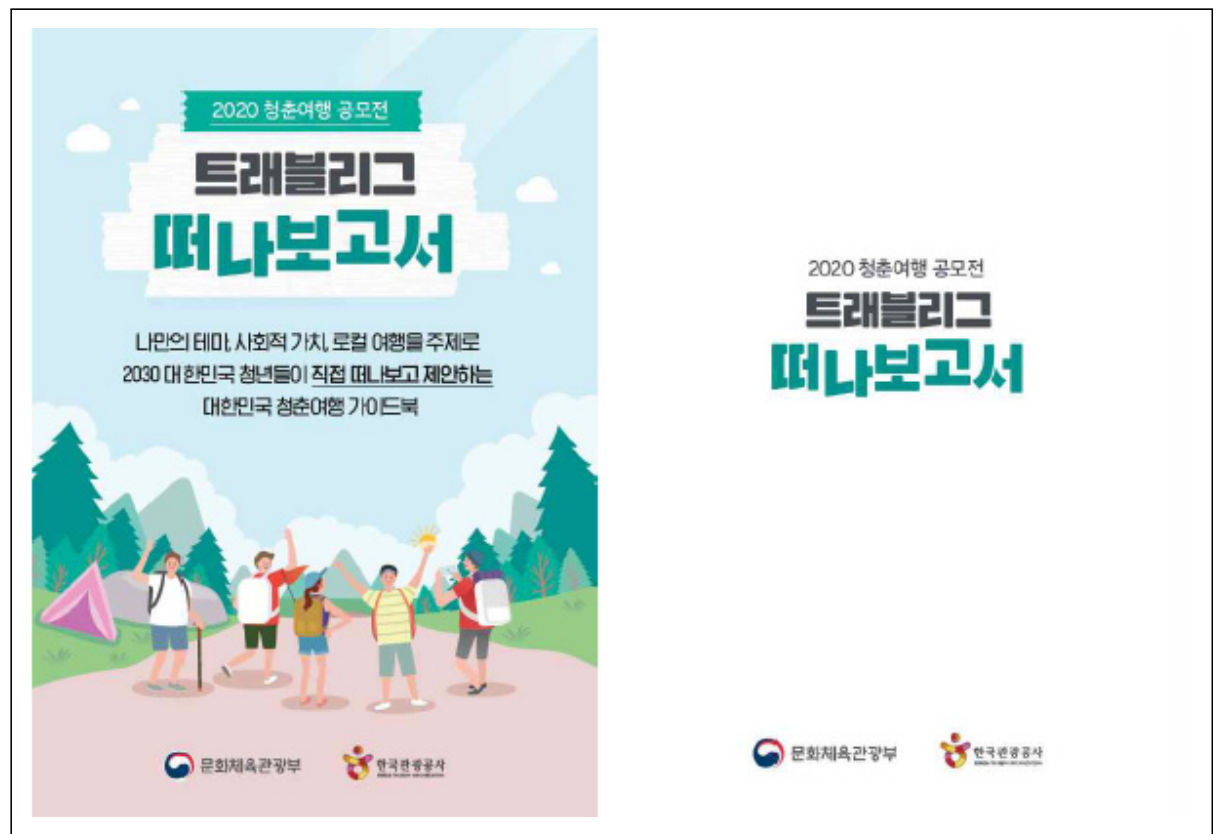

자료: 한국관광공사 내부자료(2020)

사업을 주관한 한국관광공사의 자체 조사 결과 트래블 리그 공모전 참가자들의 경우, 전체적으로 사업프로그램에 만족하고 국내여행에 대한 관심도 변화에서 긍정적 결과를 보였다. 우선 사업을 시행한 2020년, 코로나 19의 발생으로 처음에 안내했던 공모전 진행에 변동이 있기는 하였지만 참가자들의 프로그램 만족도는 전반적으로 높게 나타났 다(매우 만족: $25.8 \%$, 만족:61.3\%).

또한 본 사업의 궁극적인 목적인 국내여행에 대한 관심도 제고에 관해서도 공모전 참 여를 통해 국내여행에 대한 관심도가 높아졌다고 답한 비율이 매우 높았다(관심도 상승 응답율: $90.3 \%) .10)$

10) 다만, 이 조사는 예선통과 참가자들만을 을 대상으로 한 것이기 때문에 조사결과에 bias 가 있을 수 있다. 
[그림 4-5] 청년여행(트래블리그) 공모전 참가 이후 국내여행 관심도 변화

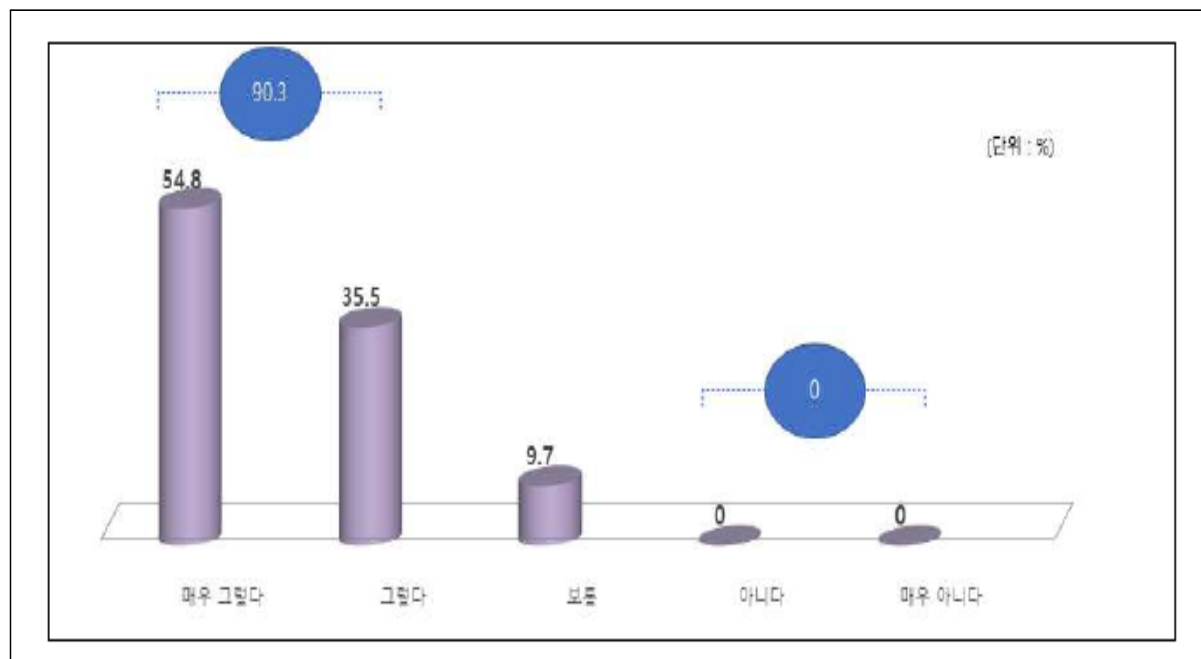

자료: 한국관광공사 내부자료(2020).

\section{2) 청년층 갭이어(Gap Year) 사업}

'갭이어(Gap Year)'는 학업을 잠시 중단하고 봉사, 여행, 진로 탐색, 교육, 인턴, 창업 등의 다양한 활동을 직접 체험하고 이를 통해 향후 자신이 나아갈 방향을 설정하는 시간 을 가리키는 용어다. 보통 북미나 유럽 등의 학생들이 고등학교 졸업 후 대학에 진학하 기 전에 1 년 정도의 시간을 가지기 때문에 학업과 학업 사이의 공백(Gap)을 본인을 돌 아보는 시간으로 사용하는 것이다.

문체부의 '청년층 갭이어' 사업은 서구의 갭이어에서 모티브(motif)를 가져오기는 했 지만 그 목적과 형태는 조금 다르다. 이 사업의 목적은 일상에 지친 청년들에게 '나를 돌아볼 수 있는 여행'을 통해 청년층 대상 새로운 국내여행(중장기 여행) 트렌드를 확산 시키는데 있다. 따라서, 사업의 지원대상도 고등학교 졸업생에게 한정하지 않고 만 20세 이상 만 34세 미만의 청년층을 대상으로 실시한다. 이 사업은 각 참가자가 직접 설계한 여행계획(최대 90 일 이내)을 공모하여 숙박비, 체험비 등 실비 지원하고 참가자의 여행 경험을 SNS를 통해서 홍보한다.

SNS를 통한 참가자 여행경험의 홍보와 국내여행 인플루언서(influencer) 양성도 동 사업의 목적 중 하나여서 트래블 리그 공모전 사업에 비하여 지원자의 SNS 활용 역량 도 중요하게 평가하고 소규모 선발(2020년 경우 5인)을 하였다. 다만 소규모 선발이기 
때문에 지역별로 기계적 분배가 아니라 여행의 컨셉에 따라서 지원대상을 선별하는 형 식을 가진다.

〈표 4-3〉 청년층 갭이어 선발자 여행주제(2020년)

\begin{tabular}{c|c|c|c}
\hline 여행주제 & 기간 & 지역 & 콘텐츠발행(편/건) \\
\hline 대한민국 섬 여행(섬지순례) & $8 / 7 ~ 9 / 27$ & 경상, 전라, 인천 & 6편/14건 \\
\hline 책 여행(Book stay) & $8 / 29 ~ 10 / 6$ & 강원, 전라, 충청 & 4편/6건 \\
\hline 방방곡곡 카라반투어 & $9 / 14 ~ 9 / 29$ & 강원, 전라 & 3편/4건 \\
\hline 제주 D-Time & $9 / 24 ~ 10 / 11$ & 제주 & 4편/5건 \\
\hline 나만을 위한 가이드 투어 & $10 / 1 ~ 11 / 6$ & 강원, 제주 & 3편/3건 \\
\hline
\end{tabular}

자료: 한국관광공사 내부자료.

참가자들이 직접 작성한 여행 콘텐츠는 SNS 채널을 통해 홍보되었는데 단일 채널이 아니라 한국관광공사 국내여행 전문채널인 방방곡곡 구석구석의 네이버 블로그, 페이스 북, 카카오 스토리 등에 게재되었다. 또한 모바일 중심의 인터넷 환경임을 감안하여 이 미지를 강조하고 각 채널 특성에 맞게 편집하여 제공되었다([그림 4-6] 참조).

[그림 4-6] 청년층 갭이어 여행콘텐츠 SNS 홍보 사례(2020년)

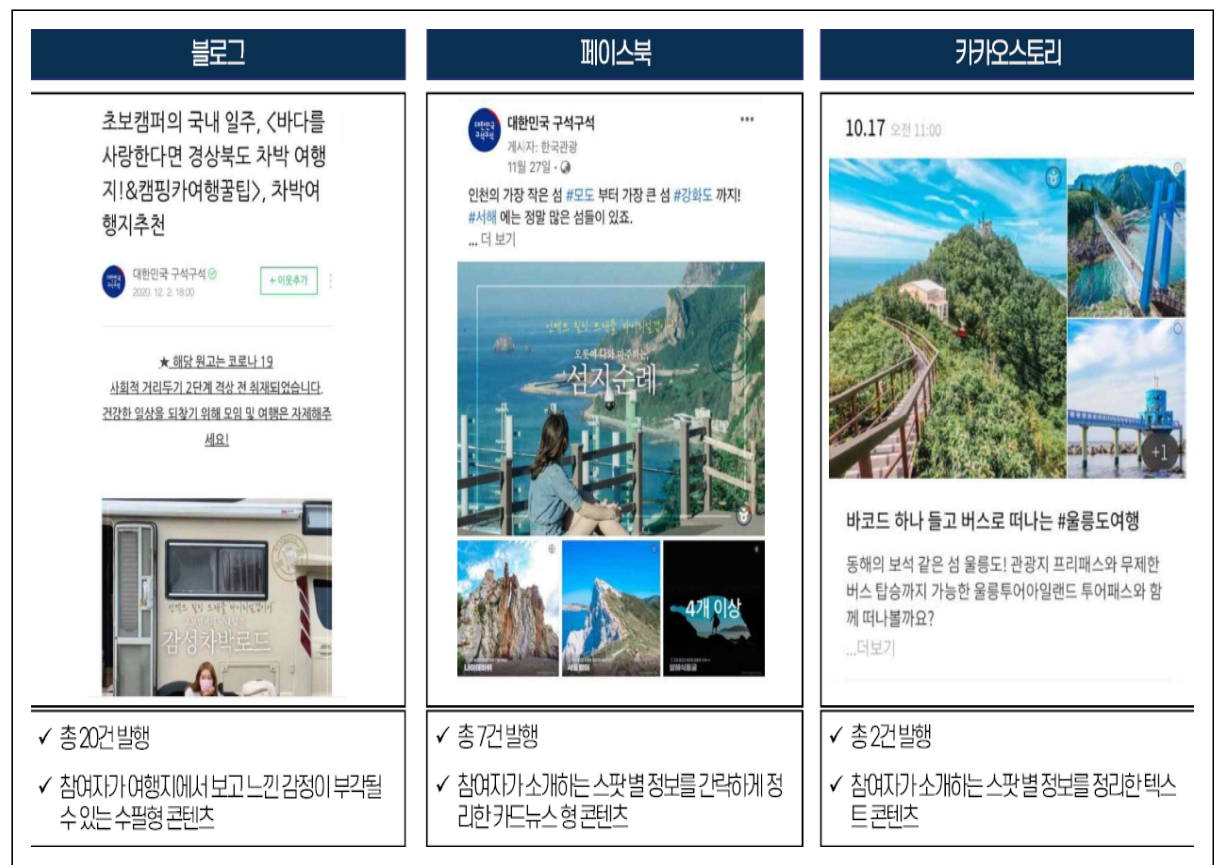

자료: 한국관광공사 내부자료(2020). 
청년층 갭이어 사업은 2021년에는 '마이 리얼 갭이어 시즌 5' 라는 이름으로 진행 중인데, 기존의 갭이어 성격 이외에 최근에 사회적으로 관심을 받고 있는 워케이션 (Workation) 과 탄소중립 주제를 사업에 반영하여 참여자를 선발하였다.

〈표 4-4〉 청년층 갭이어 선발자 여행주제(2020년)

\begin{tabular}{c|c}
\hline 여행주제 & 컨셉 \\
\hline 워케이션(Workation) & 휴가지에서 일(Work)과 휴가(Vacation)를 병행하는 형태의 여행 \\
\hline 제로-웨이스트(Zero-waster)여행 & 여행 중 쓰레기 및 탄소발생을 최소화하며 환경을 생각하는 여행 \\
\hline 소소한 전원일기 & \\
\hline
\end{tabular}

자료: 한국관광공사 "마이 리얼 갭이어 시즌5" 사업공고 정리

\section{3) 대학생 유튜브 기자단(트래블리더.mov)사업}

대학생 유튜브(Youtube) 기자단사업은 청년층이 직접 참여·생산하고 공유할 수 있는 플랫폼을 통한 청년관광 활성화를 목적으로 시행되는 사업이다. 동 사업은 앞의 두 사업 과는 다르게 대학생만을 대상으로 하고 있으며 공모를 통해 선발된 인원을 대상으로 영 상 전문 멘토를 연계하여 크리에이터 관련 교육 실시하고, 대한민국 구석구석 유튜브 채널에 제작 콘텐츠 게시, 국내 팸투어 참여 기회 등을 제공한다.

대학생 유튜브 기자단사업은 트래블리그 공모전, 갭 이어 사업에 비하여 비교적 사업 이력이 오래된 편인데, 2021년이 13번째 선발로 최초에는 관광공사 블로그를 이용하는 대학생 관광기자단 형식으로 시작해 현재는 인터넷 환경을 맞아 관광공사 유투브 채널 의 기자단형태로 발전한 것이다.

[그림 4-7] 한국관광공사 대학생 유튜브 기자단 채널 영상 Capture Image

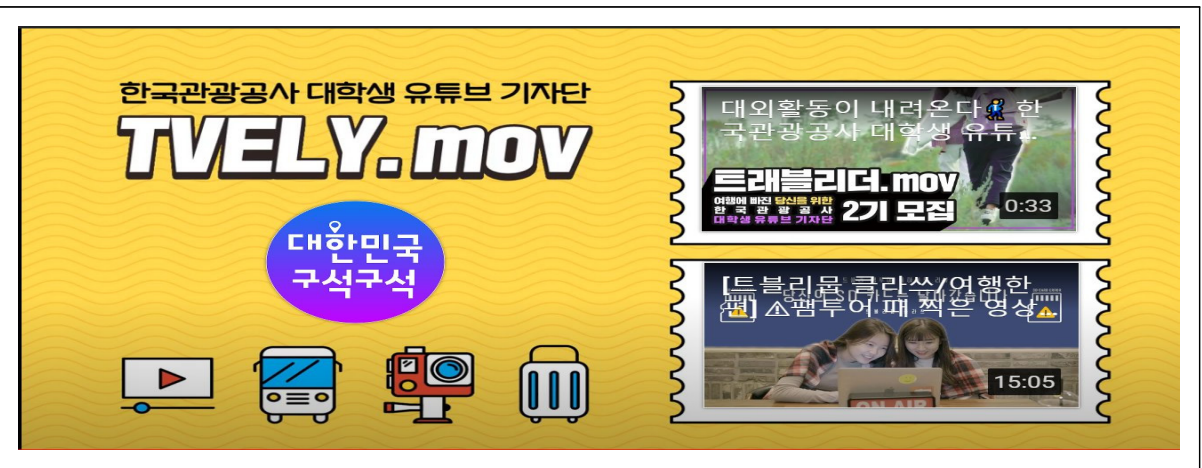

자료: 한국관광공사 Youtube 채널 “대한민국 구석구석" 


\section{나. 지자체 및 기타 청년관광 정책사업}

\section{1) 지방 지자체 체류형 관광 지원사업}

최근 체류형 여행이 각광 받으면서 국내 지방자치단체를 중심으로 관광객 유치 및 지 역경제 활성화를 목적으로 각 지방의 체류형 관광을 지원하는 프로그램이 증가하고 있 다. 이런 프로그램은 경남, 전남, 충북 등 수도권 밖의 지자체에서 실시하였으며, 만 18 세 이상의 지역 외 거주자를 대상으로 30 일 이내의 숙박비와 지역시설 입장료 등의 체험 비 등의 비용을 지원하는 것이 일반적인 내용이다.

〈표 4-5〉 청년층 갭이어 선발자 여행주제(2020년)

\begin{tabular}{|c|c|c|c|}
\hline 구분 & 지역 & 지원 대상 & 지원 내용 \\
\hline $\begin{array}{l}\text { 남도에서 한 달 } \\
\text { 여행하기 }\end{array}$ & $\begin{array}{l}\text { 전남 고흥, 영광, } \\
\text { 해남 등 } 11 \text { 개 시군 }\end{array}$ & $\begin{array}{c}18 \text { 세 이상 } \\
\text { 광주/전남 외 거주자 }\end{array}$ & $\begin{array}{l}\text { - 숙박비(1일 5만원) } \\
\text { - 지역시설 입장료 등 체험비 지원 } \\
\text { (50\% 한도) }\end{array}$ \\
\hline $\begin{array}{l}\text { 사천에서 한 달 } \\
\text { 살아보기 }\end{array}$ & 경남 사천시 & $\begin{array}{c}\text { 만 18세 이상 사천시 외 } \\
\text { 거주자 }\end{array}$ & $\begin{array}{l}\text { - 숙박비 5만원(1일/1팀, 4인 기준) } \\
\text { - 입장료 및 체험비(실비의 } 50 \%, 1 \\
\text { 일 2만원 이내) }\end{array}$ \\
\hline $\begin{array}{l}\text { 제천에서 } \\
\text { 살아보기 }\end{array}$ & 충북 제천시 & $\begin{array}{c}\text { 제천 외 타 지역에 } \\
\text { 주소를 둔 자 } \\
\text { (개별, 팀 1인 4인 이내) }\end{array}$ & $\begin{array}{l}\text { - 숙박비(1인 1박 3만원 한도) } \\
\text { - 1일 체험비의 } 50 \%(1 \text { 인 1일 2만원 } \\
\text { 한도) }\end{array}$ \\
\hline $\begin{array}{l}\text { 경남별곡, 경남에서 } \\
\text { 한 달 살기 }\end{array}$ & $\begin{array}{c}\text { 통영, 김해, 하동, 산청, } \\
\text { 합천 등 } 5 \text { 개 시군 }\end{array}$ & $\begin{array}{c}\text { 경남 지역 외 거주하는 만 } \\
18 \text { 세 이상 }\end{array}$ & $\begin{array}{l}\text { - 숙박비 5만원 } \\
\text { - 체험, 관광지 입장료 지원 }\end{array}$ \\
\hline $\begin{array}{l}\text { 전남에서 먼저 } \\
\text { 살아보기 } \\
\text { (청년형) }\end{array}$ & 전남 영광군 & $\begin{array}{c}\text { 18세-39세 이하의 } \\
\text { 타시도 거주 청년 } \\
\text { (도내 청년은 선발인원의 } \\
30 \% \text { 이내) }\end{array}$ & $\begin{array}{l}\text { - 참가자 체류공간, 지역체험 교육 } \\
\text { 프로그램 등 지원 } \\
\text { - 생활비(식비, 교통비 등), 여행자보 } \\
\text { 험 등 자부담 }\end{array}$ \\
\hline
\end{tabular}

자료: 해당 지자체 사업안내 자료 정리

지방 지자체들의 지역 체류형 관광지원 사업은 문체부에서 실시하는 Gap Year 프로 그램과 유사한데, Gap Year 사업과 달리 지자체들의 사업은 지원 대상을 청년층으로 한정하지는 않는다. 그러나 선발 조건에 블로그, 인스타그램, 페이스북 등을 활용한 지 자체의 체류여행의 정기적 게재가 있어 상대적으로 디지털 환경에 익숙한 청년층에게 유리하게 진행된다. 


\section{2) 코레일 내일로 패스 Youth}

코레일 내일로 패스 YOUTH는 만 25세(단, 2021년 까지 한시적으로 만 34세 이하 까지 사용범위 확대) 이하 청년들이 패스 한 장으로 일정기간 동안 해당열차를 무제한 이용하며 여행할 수 있는 기차 패스이다. 내일로 패스 YOUTH는 유럽의 대표적인 기차 패스인 유레일패스처럼 우리나라 기차를 통해 여행을 하는 청년들에게 교통비 부담을 덜고 국내여행을 활성화시키는 목적을 가지고 있다.

본 패스 소지자는 KTX의 좌석, 일반열차(ITX-청춘, ITX-새마을, 새마을, 누리로, 무 궁화, 통근열차)의 좌석 · 입석(자유석)을 할인된 가격(연속 7일권 기준 60,000 원)으로 자유롭게 이용할 수 있고, 또한 발매 역에 따라 해당지역에서 이용할 수 있는 관광, 체험 할인 쿠폰을 함께 제공한다. 


\section{제2절 일본 청년관광 정책과 사례11)}

\section{1. 일본 청년관광 정책 배경}

일본은 1994 년을 피크로 일본 전체 인구의 여행 참가율과 소비규모가 감소해왔다. 그 배경에는 일본 거품경제가 꺼지고 장기침체에 빠진 것과 일본 인구가 노령화되면서 낮은 출산율로 인구감소 등의 원인이 꼽힌다. 2012년 일본 아베 신조가 집권하면서 과 감한 금융완화와 재정지출 확대 등으로 일시적 소비 경제 반등으로 인하여 2014년부터 는 국내 여행 소비액이 약간의 반등을 보여주고 있지만, 아직 이전 수준으로의 회복까지 기대하기에는 어려운 수준이다([그림 4-8] 참조).

[그림 4-8] 일본인 국내여행 소비액 추이(2004-2019)

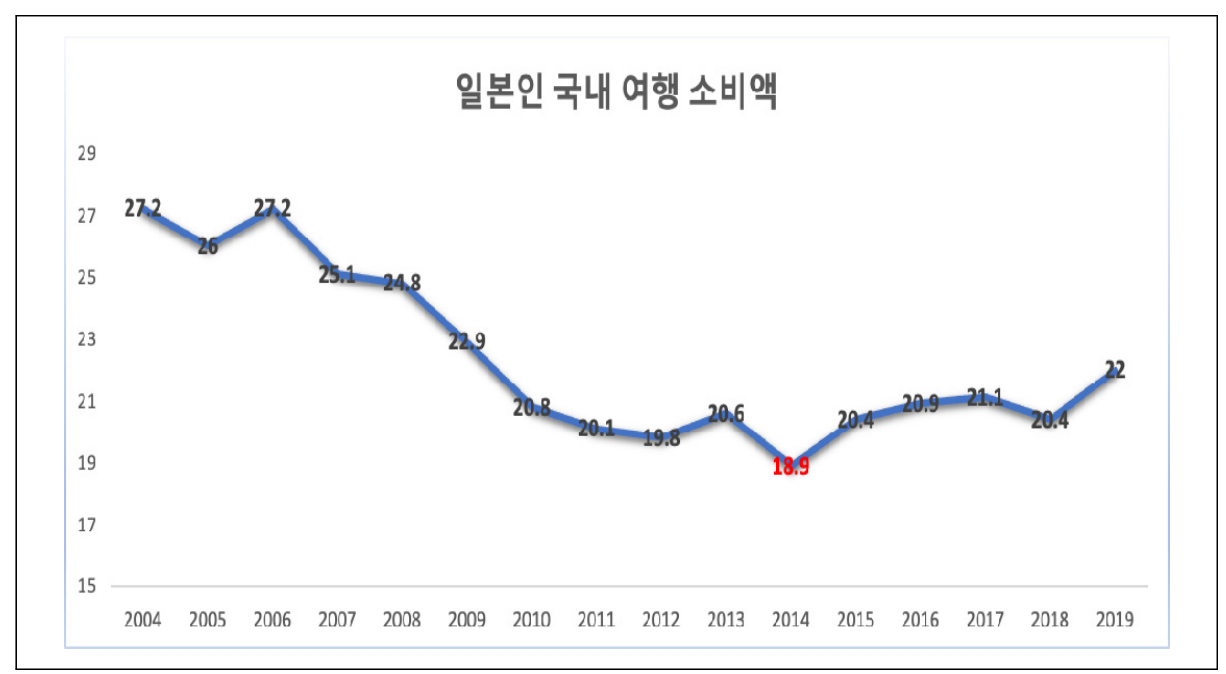

자료: 일본 관광청(2020):「여행 · 관광 소비 동향 조사」

11) 한국방송통신대학교 여경진 교수 \& 일본 Tezukayama University 강성숙 교수의 자문원고를 참고하여 작성함 
일본 청년들이 여행에 적극적이지 않은 현상에 대해 2-30대 일본 청년층은 일본의 버블경제 몰락으로 장기 경제침체기(잃어버린 20년)에 태어나 소극적이며 미니멀 라이 프를 추구하기 때문으로 설명되고 있다. 일본의 MZ 세대는 1987 2001년생이 여기에 해당하는데 이들은 취업에도 적극적이지 않아 아르바이트와 비정규직으로 최소의 수입 만 유지하고 출세나 명예 등에도 관심이 없어 일본에서는 이들을 ‘사토리(得道:득도)' 세 대라고 부르고 있다. 저성장의 여파와 고용시장 불안, 불확실한 미래로 현재의 행복을 추구한다는 점에서 '사토리' 세대는 $\mathrm{MZ}$ 세대와 유사하지만 일본 $\mathrm{MZ}$ 세대인 '사토리' 세대의 차이점은 우리나라의 $\mathrm{MZ}$ 세대와는 약간 다른 모습을 보인다.

2010년 일본 관광청의 관광시장 조사 분석 결과, 미래 관광의 주요 소비층인 20대와 30 대의 여행 빈도가 감소 추세이고 특히 20대 남성은 지난 5년 간 세대별남녀별 여행 빈도가 가장 낮게 나타났고, 과거 여행 빈도가 높았던 20대 여성도 2009년 큰 폭으로 하락하여 일본 정부에서는 일본 청년관광 활성화의 필요성을 인식하게 된다.

\section{2. 일본 청년관광 정책 사례}

관광청은 산관학의 관계자로 구성된 「청년여행진흥연구회(若者旅行振興研究会)」를 설 립하여 2010년 7월부터 2012년 6월까지 젊은 세대의 여행진흥을 위한 조사를 실시하 고, 청년 여행의 경향 및 진흥을 위한 대책을 공표하였다. 12)

이후 관광청은 장관 표창 및 와카타비 \수업(若旅丸授業) 등 청년관광 진흥활동의 보 다 원활한 전개를 위해 2014년 3월에「청년여행진흥연락회(若者旅行振興連絡会)」를 개 최하였다. 「청년여행진흥연락회」는 지금까지 관광청의 사업 보고 및 향후 반영, 참석자 가 실시한 청년여행 진흥에 관한 사업 등의 정보를 공유하는 대토론회 성격의 자리였다.

이후 2013년부터 2015년까지 「지금이 아니면 할 수 없는 여행이 있다(今しかできな い旅がある)」를 슬로건으로 하여 대대적인 청년여행 '와카타비(若旅)' 캠페인을 펼쳤다.

12) 1기는 2010년 7월부터 2011년 6월까지, 2기는 2011년 11월부터 2012년 6월까지 구성되어 개최 


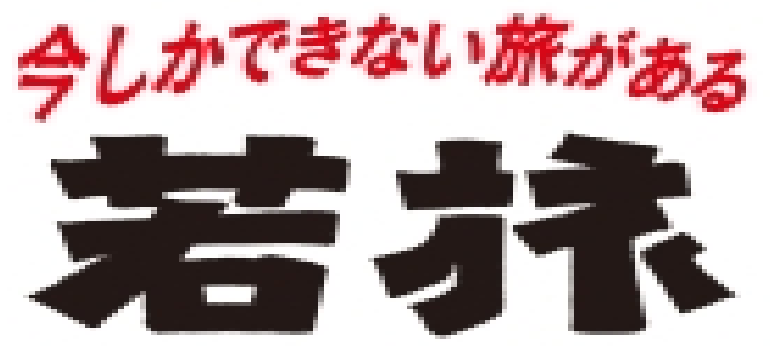

자료: 일본 관광청 홈페이지 (https://www.mlit.go.jp/kankocho/topics05_000038.html)

또한 일본 정부는 이러한 캠페인과 함께 청년여행 진흥에 기여한 지방공공단체, $\mathrm{NPO}$, 기업, 개인 등의 사례를 모집하고, 그 중 우수 사례를 선정해 관광청 장관상을 수여하고 사례집을 펴내는 등의 홍보활동도 병행하였다.

〈표 4-6〉 일본 청년여행 우수사례 시상내역

\begin{tabular}{|c|c|c|c|}
\hline & 제1회(2013.6.27.) & 제2회(2014.6.25.) & 제3회(2015.9.25) \\
\hline $\begin{array}{l}\text { 관광청 } \\
\text { 장관상 }\end{array}$ & trippiece((주)trippieace) & $\begin{array}{c}\text { 사회문제발신형 } \\
\text { 플랫폼:리디러버의 } \\
\text { 스터디투어((주)Ridilover) }\end{array}$ & $\begin{array}{c}\text { 젊은층 행동 지원 } \\
\text { 플랫폼마지뇍부(マジ经部)」 } \\
\text { ((주)리크루트 라이프 스타일) }\end{array}$ \\
\hline 장려상 & \begin{tabular}{|c}
-청년 수요 창출에 의한 일본 \\
스노우 에리어 재활성화 \\
프로젝트 \\
유키마지(雪マジ)!19-snow \\
magic((주) 리쿠르트 라이프 \\
스타일) \\
-세계 일주에 관한 정보발신, \\
이벤트 개최(세계일주단체 \\
TABIPPO) \\
-오리지널 애니메이션『걸즈 \\
앤 판처와 연동한 꿈과 마법의 \\
이야기』,친가같은 \\
마을오오아라이에서만 느낄 수 \\
있는 여행((주)Oarai크리에티브 \\
매니지먼트)
\end{tabular} & $\begin{array}{c}\text {-청년여행 in 야마구치 } \\
\text { 야마구치현내 온리 원 } \\
\text { 기업방문과 관광매력 발견의 } \\
\text { 여행 3일간(주)서경은행, } \\
\text { 히로시마 경제대학) } \\
\text {-산정 카페 프로젝트-후세에 } \\
\text { 전하고 싶은 산악여행이 } \\
\text { 있다(산정cafe-비기너를 위한 } \\
\text { 등산 서클-) } \\
\text {-도농 교류프로젝트 in } \\
\text { 이이데마치((주)JTB } \\
\text { 코퍼레이트 세일즈 }\end{array}$ & $\begin{array}{c}\text {-여행프로듀스부 in } \\
\text { nittan((주)리쿠르토 북해도쟈란) } \\
\text {-TABIPPO 젊은층이 여행하는 } \\
\text { 문화를 창조하는 트러블 } \\
\text { 커뮤니티플랫폼((주) TABIPPO) } \\
\text {-관광계 대학생에 의한 } \\
\text { 「청년여행의 기회창조」를 위한 } \\
\text { 총합적 조직(일본학생관광연맹) }\end{array}$ \\
\hline $\begin{array}{l}\text { 홋카이도 } \\
\text { 블록상 }\end{array}$ & - & - & $\begin{array}{c}\text { 청춘단기여행을 해라(Tourister } \\
\text { BUZZ 구락부) }\end{array}$ \\
\hline
\end{tabular}


〈표 계속〉

\begin{tabular}{|c|c|c|c|}
\hline & 제1회(2013.6.27.) & 제2회(2014.6.25.) & 제3회(2015.9.25) \\
\hline $\begin{array}{l}\text { 도호쿠 } \\
\text { 블록상 }\end{array}$ & $\begin{array}{c}\text { 후쿠시마를 느끼고 생각하는 } \\
\text { 스터디 투어스타나후쿠 }\lrcorner \\
\text { (스타구후쿠 프로젝트) }\end{array}$ & $\begin{array}{c}\text { 스포츠 YUKIYOSE } \\
\text { (특정비영리활동법인 } \\
\text { 톱스포츠 컨서시엄 아키다) }\end{array}$ & $\begin{array}{c}\text { 블루 투어리즘-미나미 } \\
\text { 산리쿠정의 바다를 중심으로 한 } \\
\text { 관광체험 교류사업 }\end{array}$ \\
\hline $\begin{array}{l}\text { 간토 } \\
\text { 블록상 }\end{array}$ & $\begin{array}{c}\text { 하챠게야로 여행(일반사단법인 } \\
\text { 미나카미정 관광협회) }\end{array}$ & Lunch Trip & $\begin{array}{c}\text { 「포토링 in 아시오」「기모노 데 } \\
\text { 닛코 꽤 좋은 곳」 } \\
\text { 등(닛코창신숙) }\end{array}$ \\
\hline $\begin{array}{l}\text { 주부 } \\
\text { 블록상 }\end{array}$ & $\begin{array}{c}\text { 『웃음의 힘으로 이누야마를 } \\
\text { 건강하게!』프로젝트 } \\
\text { (이누야마시 관광협회) }\end{array}$ & - & 첫 여행사업(이세시) \\
\hline $\begin{array}{l}\text { 호쿠리쿠/ } \\
\text { 신에츠 } \\
\text { 블록상 }\end{array}$ & - & $\begin{array}{c}\text { 대학 세미나 합숙 } \\
\text { 유치· 코디네이트 } \\
\text { 사업(특정비영리활동법인 } \\
\text { 가나자와 관광창조회의) }\end{array}$ & - \\
\hline $\begin{array}{l}\text { 긴기 } \\
\text { 블록상 }\end{array}$ & $\begin{array}{c}\text { 유마온천 } \\
\text { 유케무리대학(사단법인 } \\
\text { 유마온천 관광협회) }\end{array}$ & $\begin{array}{l}\text { 선플라워 청년 선상 여행 추진 } \\
\text { 프로젝트((주) 페리 선플라워) }\end{array}$ & $\begin{array}{c}\text { 신이마미야관광 인포메이션 } \\
\text { 센터를 거점으로 관광 } \\
\text { 마을만들기 사회적 실현 } \\
\text { (한남대학 국제관광학부) }\end{array}$ \\
\hline $\begin{array}{l}\text { 츄고쿠 } \\
\text { 블록상 }\end{array}$ & - & $\begin{array}{c}\text { 스포츠에 의한 지역활성화 } \\
\text { 프로젝트(히로시마 경제대학 } \\
\text { 진동관 스모츠에 의한 } \\
\text { 지역활성화 프로젝트) }\end{array}$ & $\begin{array}{c}\text { 관광객을 여행자로 변화, 지역의 } \\
\text { 본질을 체험하는 여행을 } \\
\text { 제공하는 숙박(게스트하우스) } \\
\text { 운영 } \\
\text { (구라시키 마을 안 『구루마좌`) }\end{array}$ \\
\hline $\begin{array}{l}\text { 큐슈 } \\
\text { 블록상 }\end{array}$ & - & - & $\begin{array}{c}\text { 유니버시티 · 컬리지 남규슈 } \\
\text { (구마모토현, 미야자키현, } \\
\text { 가고시마현, 니시니혼 } \\
\text { 여객철도(주)) }\end{array}$ \\
\hline $\begin{array}{l}\text { 심사원 } \\
\text { 특별상 }\end{array}$ & $\begin{array}{c}\text { 마루오우치 아사대학 환경학부 } \\
\text { 지역프로듀서 클럽 } \\
\text { (마루오우치 아사대학 } \\
\text { 기획위원회) }\end{array}$ & $\begin{array}{l}\text { 사무라이카레 프로젝트 } \\
\text { (사무라이 인터내셔널) }\end{array}$ & - \\
\hline
\end{tabular}

출처: 일본 관광청(観光庁) 홈페이지 https://www.mlit.go.jp/kankocho/news05_000150.html

\section{최근 조사를 보면 일본 20-30대의 국내여행 참가율이 조금 상승하였지만 지속적인지} 에 대해서는 좀 더 관찰이 필요하다. 
[그림 4-10] 일본인 국내 숙박여행 경험률 추이 (2012-2019)

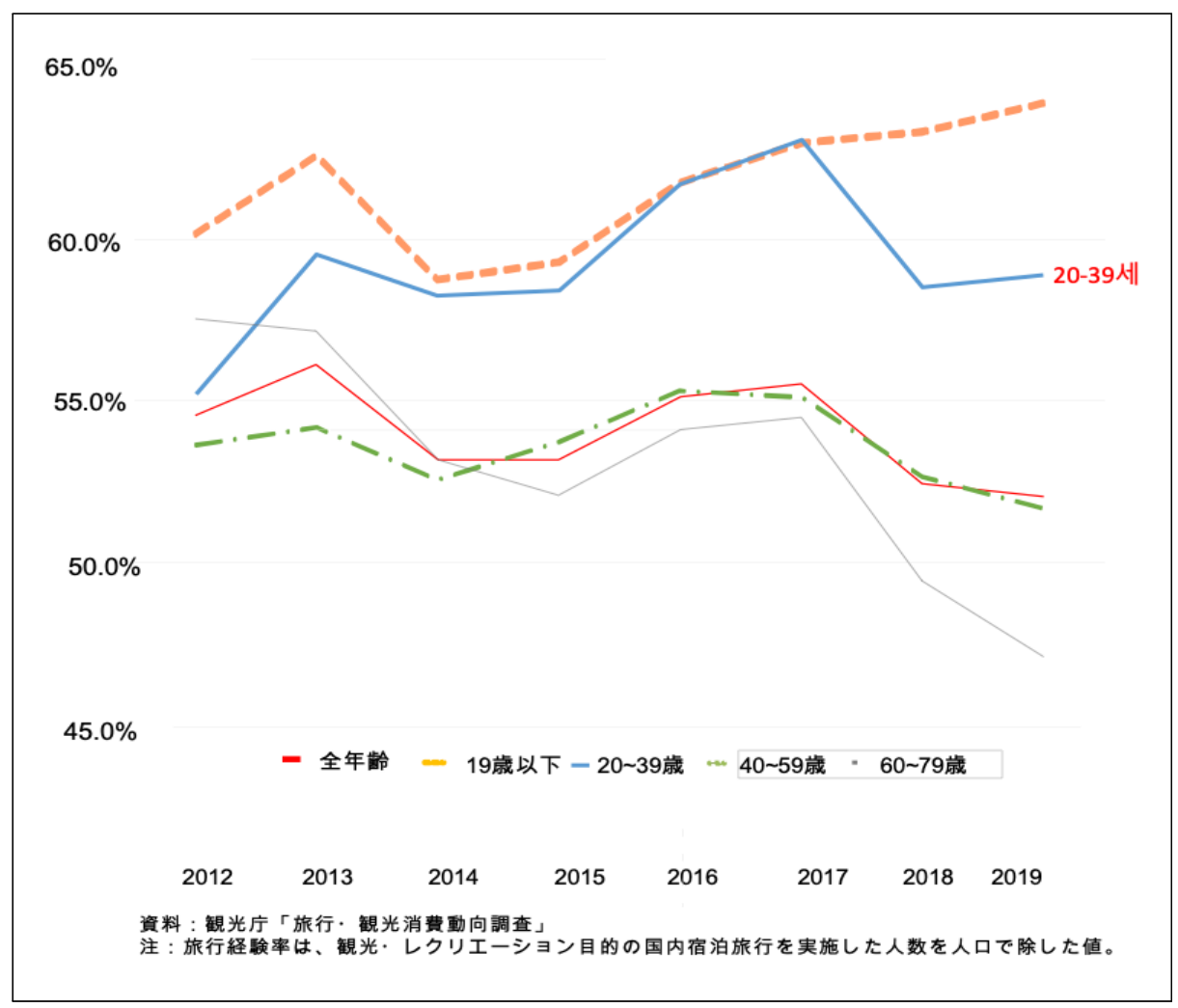

[그림 4-11] 일본인 국내 숙박여행 경험률 비교 (2018 vs 2019)

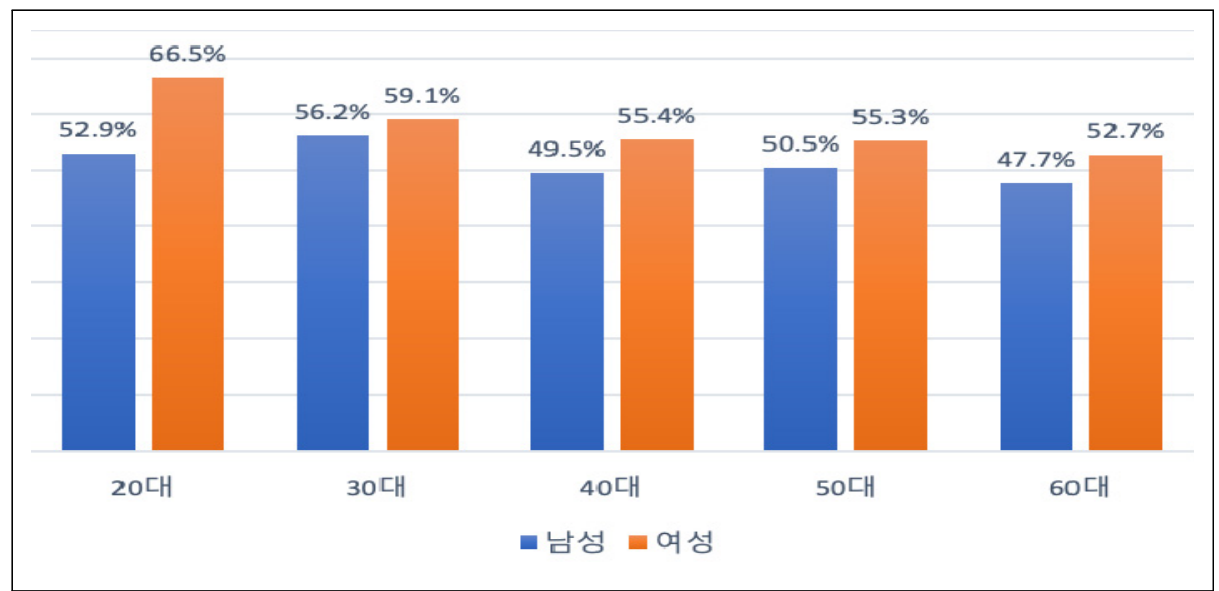

자료: 일본 관광청(2020): 「여행 · 관광 소비 동향 조사」 
다만, 과거 여행에 소극적이던 일본 청년층이 상대적으로 과거와 비교하여 국내여행 에 대한 관심도가 높아진 것으로 나타나서 이는 일본 국내관광 시장에 긍정적인 요소로 평가하고 있다.13) 또한 일본인의 세대별 여행 특징에 대한 결과를 보면 2-30세대에서 특정목적을 위한 여행(Special Interest Tourism), SNS를 해 여행지에 대한 정보 습득 과 관심 등이 높게 나타나 일본 청년층도 여행 행태에서는 $\mathrm{MZ}$ 세대의 여행 행태와 유사 한 모습을 보인다.

[그림 4-12] 일본인 국내여행 행태 세대별 비교 (2018 vs 2019)

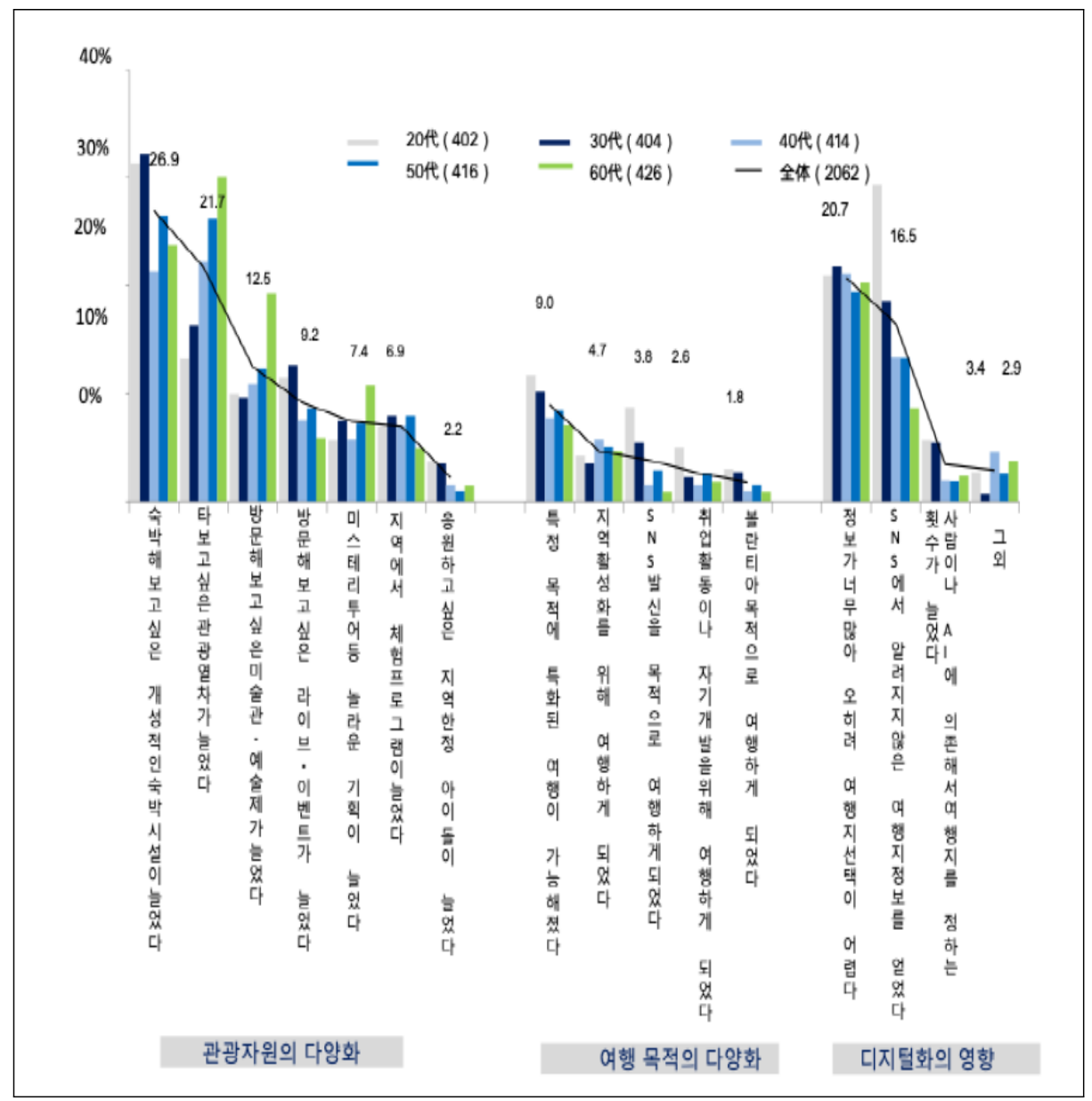

자료: 일본 관광청(2020):「여행 · 관광 소비 동향 조사」

13) 2015년 이후 방일시장이 커지고, 외국인들의 방일이 증가하면서 외국 여행객들의 직/간접 접촉을 통하여 일본 청년층도 일본 여행에 대한 관심이 커지는 효과를 불러일으킨 것으로 그 원인을 추정하고 있음 


\section{3. 일본 워케이션(Workation) 현황}

일본은 우리나라와 유사하게 근로시간이 길며, 휴가사용이 짧으며 특정한 시기에 집 중된다. 일본 청년층의 경우 주요한 여행제약 요인 중 하나가 시간적 여유가 없는 것이 다([그림 4-13] 참조).

[그림 4-13] 일본 청년층 국내여행 제약요인

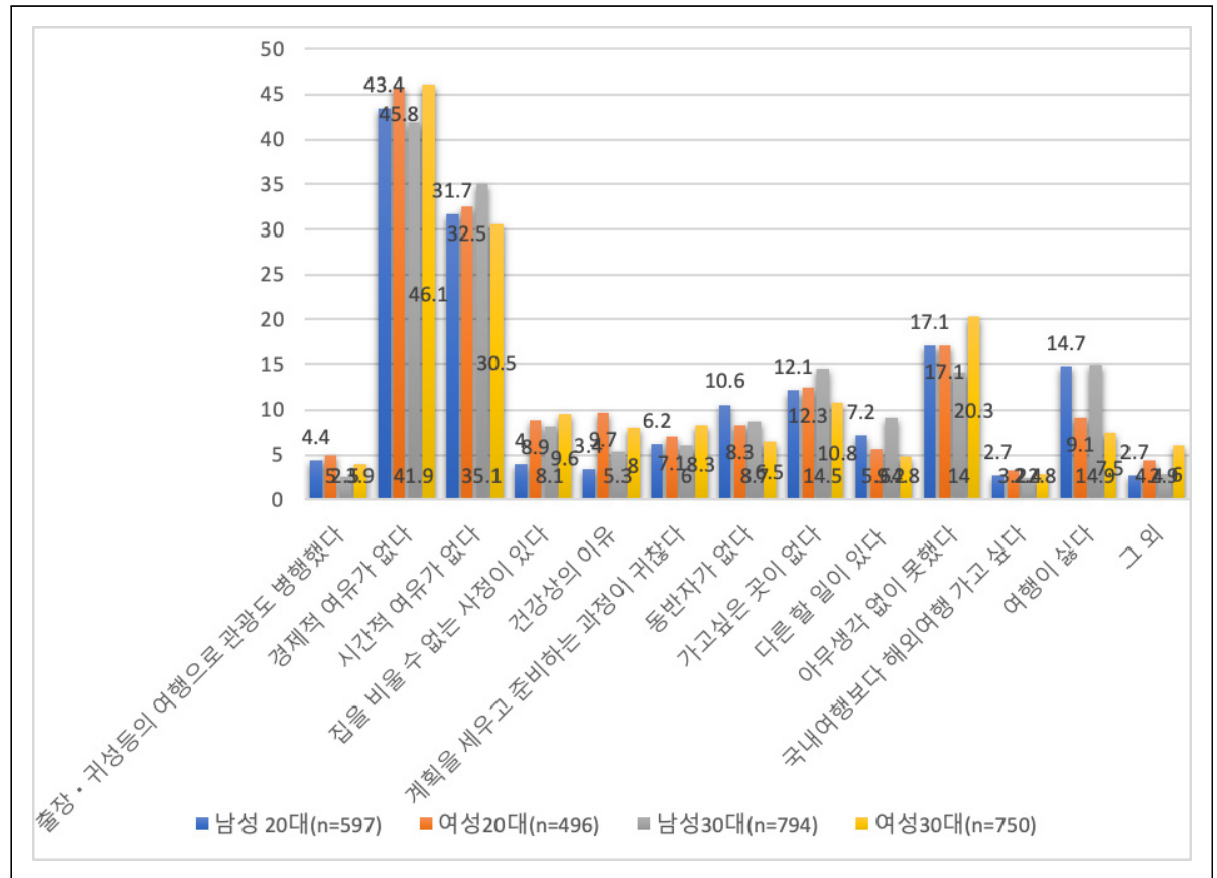

자료: 일본 관광청(2020):「여행 · 관광 소비 동향 조사」

일본 정부도 우리나라처럼 휴가 분산과 휴가의 적극적 활용을 추진하여 왔지만, 획기 적인 전환을 가져오기는 어려웠다. 그런데 최근 IT 의 발달로 텔레워크(Tele-work: 원 격지 근무)를 활용한 워케이션(Workation)이 새로운 휴가문화의 하나로 떠오르고 있다. 특히 워케이션은 코로나19 발생으로 인해 재택근무 확산과 맞물려 젊은 층을 중심으로 확산되는 경향이다. 


\section{가. 일본 워케이션 개요}

코로나19 이후 일본기업들의 재택근무 확산과 맞물려서 워케이션에 대한 관심이 높 아지면서 일본 관광청은 워케이션 확대를 적극 추진하고 있다. 특히 2020년 일본 관광 전략실행추진회의(우리나라의 국가관광전략회의에 해당함)에서 워케이션을 '새로운 여 행 스타일'로 제안하였다.

워케이션은 기업과 근로자의 상황에 따라서 다양한 형태로 진행할 수 있지만, 일본에 서는 크게 휴가형, 업무형으로 구분하고 있으며 업무형은 다시 지역과제 해결형, 합숙형, 위성 오피스형으로 나눠진다.

○ 휴가형: 리조트나 관광지에서 여가를 즐기면서 텔레워크를 하는 스타일로써 개인 단위가 기본이다. 휴가를 목적으로 하기 때문에 이동이나 숙박비용은 개인이 부담 하며, 「휴가형」은 기업의 유급휴가 취득촉진등의「복리후생형」으로 불린다. 일본 워케이션의 본격적인 계기가 된 유형이다.

$\bigcirc$ 업무형: 일을 메인으로 하는 스타일. 업무의 전후에 휴가를 즐기는 형태이다. 기업 이나 대상지역의 수요에 맞추어, 「지역과제해결형」, 「합숙형」, 「위성오피스형」 등 으로 분류된다.

- 지역과제해결형: 지역 관계자들과의 교류를 통해 지역과제를 같이 고심하는 것이 며, 이러한 유형으로는 ESG의 조직화가 요구되는 기업에 있어서 특히 주목을 받 고 있다. 향후 지역과제해결형 워케이션을 도입하는 기업이 늘어날 것으로 기대 된다.

- 합숙형: 리조트 등 일반적인 업무환경과 다른 장소에서 회의, 연수를 하므로 새로 운 아이디어 창출 등에 활용되고 있다, 이러한「합숙형」을 적극적으로 유치하는 곳은 나가노현 다테나시쵸가 유명하다.

- 위성오피스형: 일반적으로 회사가 설치하고 있는 위성오피스를 활용한 원격 근무 형태이다. 코로나19의 확산으로 인해 재택근무가 급증하면서 좀 더 효율적으로 업무에 집중하도록 환경구축을 위해 위성오피스가 급증하고 있다. 일본 와카야마 현 시라하마쵸가 이러한 위성오피스 구축을 통해 기업의 워케이션 유치에 적극적 이다. 


\section{워케이션 \\ (Work + Vacation)}

[휴가형]

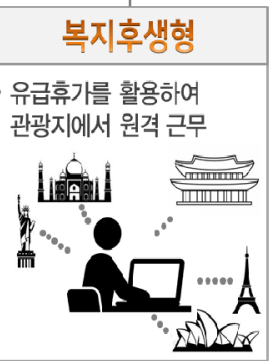

[업무형]

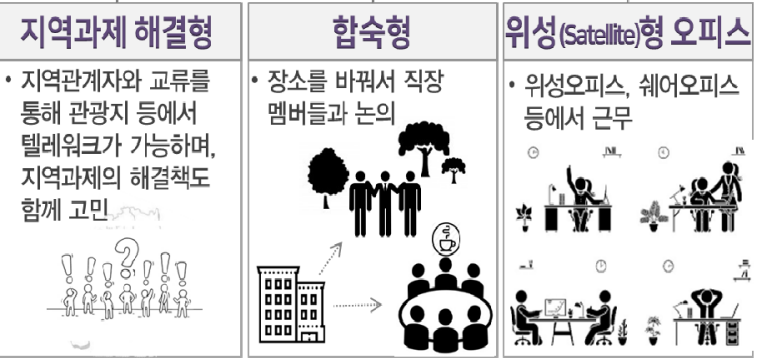

자료: https://japan-telework.or.jp/ (일본 원격근무협회) 연구자 수정

이러한 일본의 워케이션이 주목받는 이유는 코로나 19 로 인한 재택근무 확산이 이유 기도 하지만, 일본사회의 고질적인 문제인 휴가 사용 어려움이나 지방소멸 문제 등에 대한 새로운 접근법으로도 그 가능성을 보여주고 있기 때문이다.

일본의 야노 경제 연구소의 보고서에 따르면 일본의 워케이션 시장은 2020년 699억 엔에서 20215년에 약 5배 규모인 3,622억 엔까지 빠르게 성장할 것으로 예측되고 있다 (KOTRA, 2021). 
[그림 4-15] 일본 워케이션 시장 전망(2020 2025)

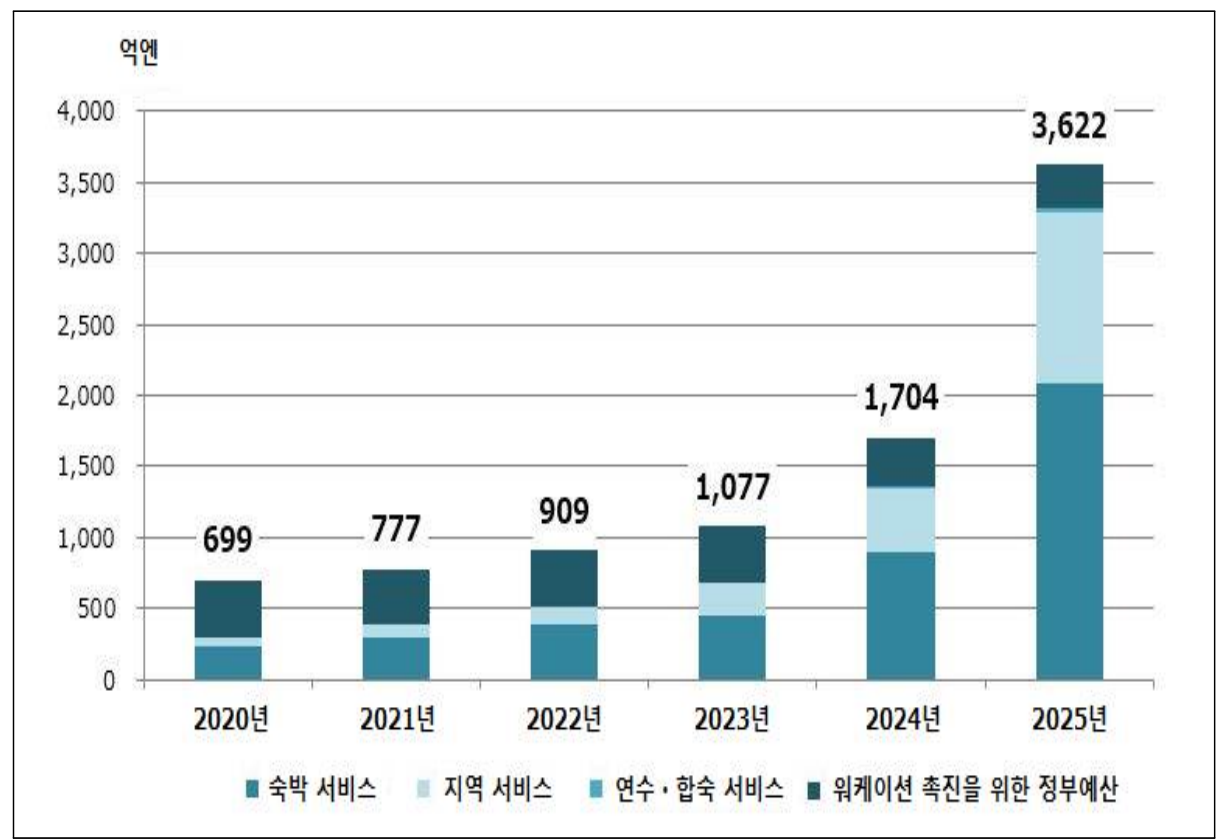

자료: 일본 야노경제연구소 (KOTRA 트렌드 보고서, "일본 워케이션 시장동향" 에서 재인용)

\section{나. 워케이션 추진지역 사례: 와카야마현(和歌山県) 시라하마초(白浜町)}

외카야마현의 시라하마초는 일본에서 워케이션을 가장 활발하게 진행하고 있는 곳으 로 평가된다. 2017년부터 지자체가 중심이 되어 지역관광산업 재생을 위해서 일본 도쿄 의 100 여개가 넘는 기업들과 협력을 통하여 워케이션 프로그램을 실시하고 있다.

시라하마쵸는 와카야마현의 남쪽 해안에 위치한 인구 약 21,000 명 정도의 리조트 지 역으로 '일본의 와이키키' 로 불릴 정도로 유명한 관광지였다. 그러나 계절 편중성이 관 광철인 여름에 집중되고, 인구도 지난 20 년간 $20 \%$ 가 감소하는 문제점을 가지고 있었 다. 간사이 지역이지만 기이반도(紀伊牛島)의 최남단에 위치하여 도쿄 지역에서 오는 방 문객은 매우 적은 문제도 가지고 있었다. 14)

14) 한국경제. 2021.03.12. "워케이션 성지된 일본의 와이키키: 시라하마의 변신" 
[그림 4-16] 일본 와카야마현(和歌山県) 시라하마초(白浜町) 위치

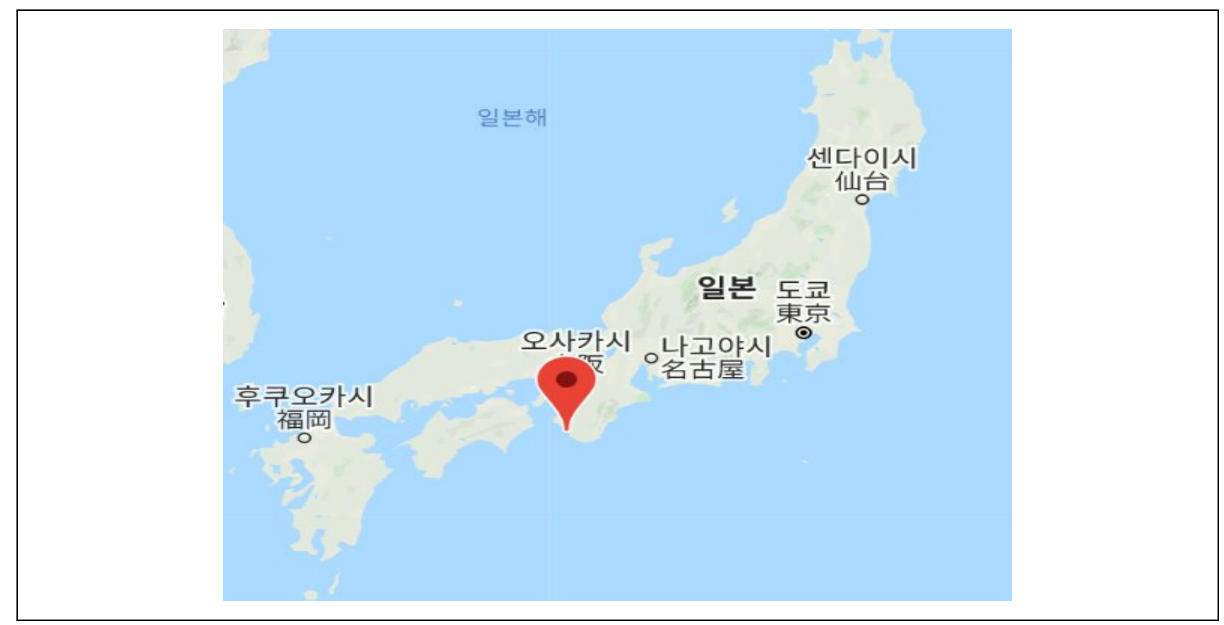

자료: Goggle Maps

정체된 지역관광 산업을 돌파하기 위해서 시라하마초는 워케이션에 힘을 쏟았는데, 우선 일본 도쿄에 위치한 IT 기업의 위성 오피스를 유치하는데 공을 들였다. 이를 위해 지역 전체에 $\mathrm{WiFi}$ 를 무료로 개방하고, 심지어 해변에서도 $\mathrm{WiFi}$ 가 가능하게 하였다.

또한 워케이션 프로젝트를 홍보하기 위하여 별도 홈페이지를 개설하고 워케이션 가이 드북도 제작하여 배포하였다.

[그림 4-17] 일본 와카야마 워케이션 프로젝트 홈페이지

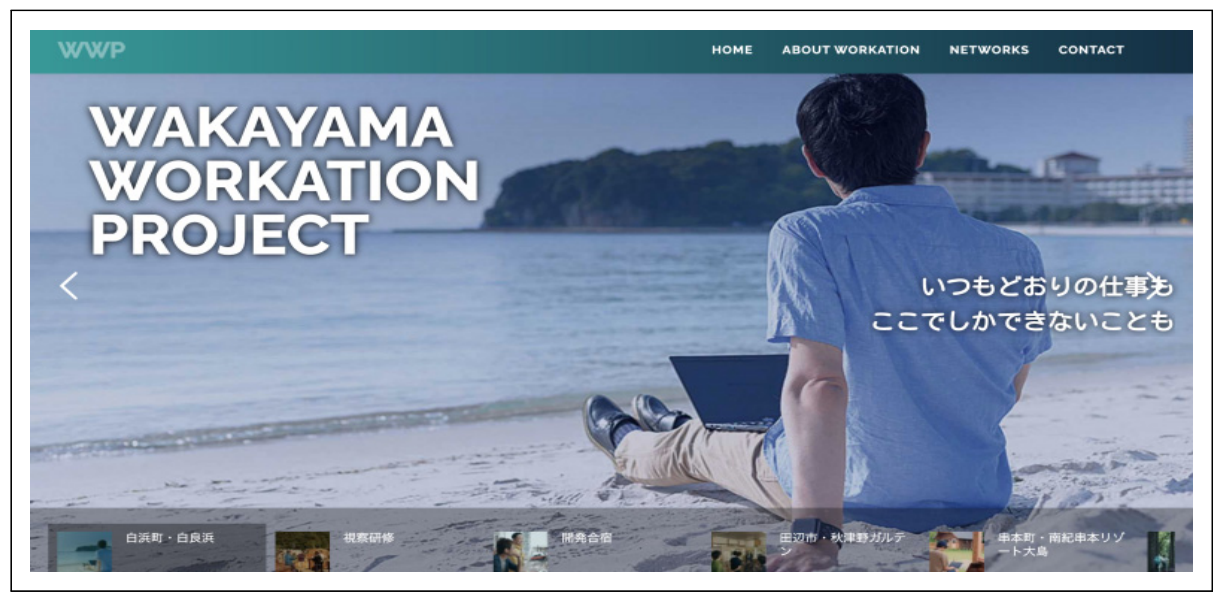

자료: https://wave.pref.wakayama.lg.jp/020400/workation/index.html 
[그림 4-18] 일본 와카야마 워케이션 가이드북에 소개된 원격근무 환경

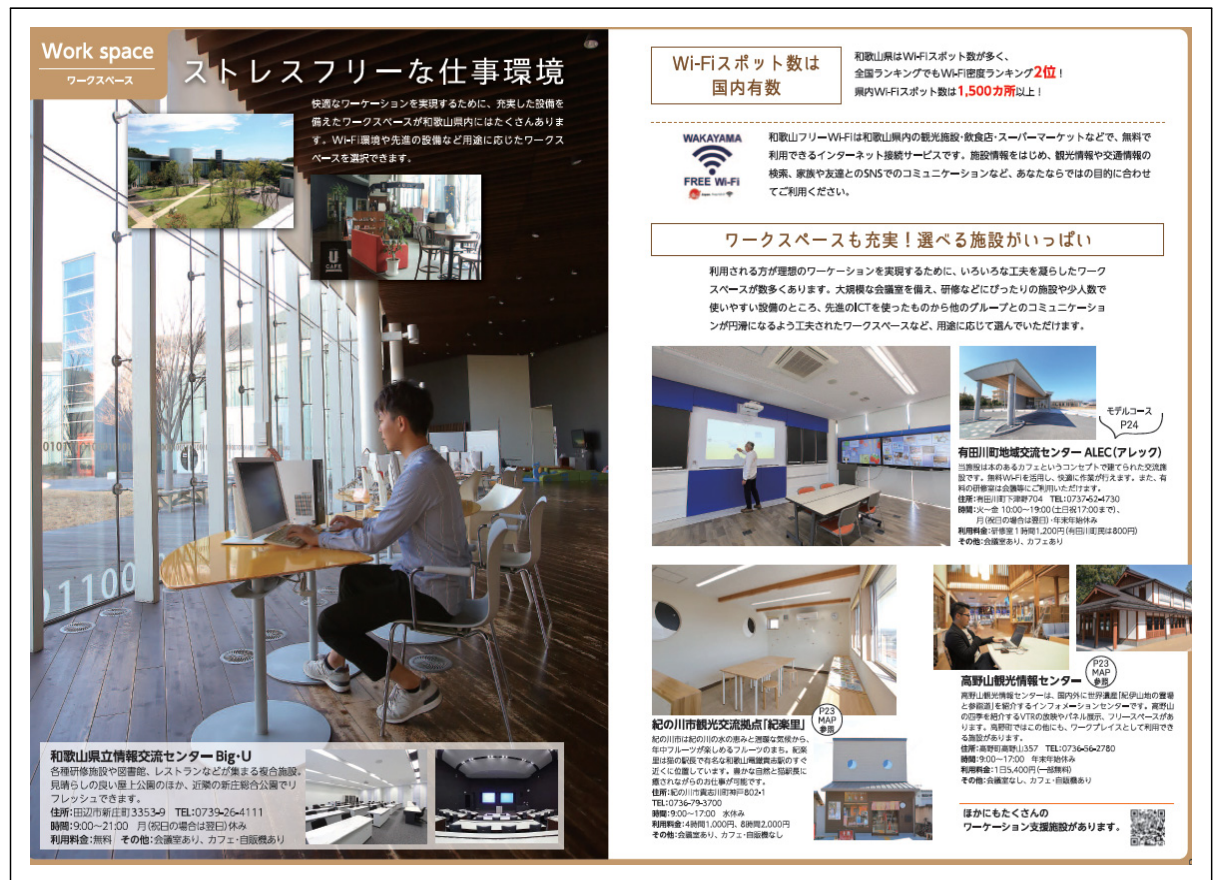

자료: Wakayama Workation Project Guide book

이러한 지자체의 노력 덕분에 일본의 NEC, 미쯔비시, 세일즈 포스(Sales Forces), JAL 등의 대기업이 와카야마현 시라하마초에 워케이션 위성 사무소(satellite office)를 열었다. 일례로 일본의 IT 클라우드 업체인 '세일즈 포스' 직원들은 3개월씩 교대로 워 케이션 프로그램에 참가하는데 근무 외 시간이나 주말에는 지역의 관광지를 방문하고 하이킹, 온천, 골프와 같은 다양한 레저를 경험한다. 
[그림 4-19] 일본 와카야마 워케이션 참가자들의 하이킹 모습

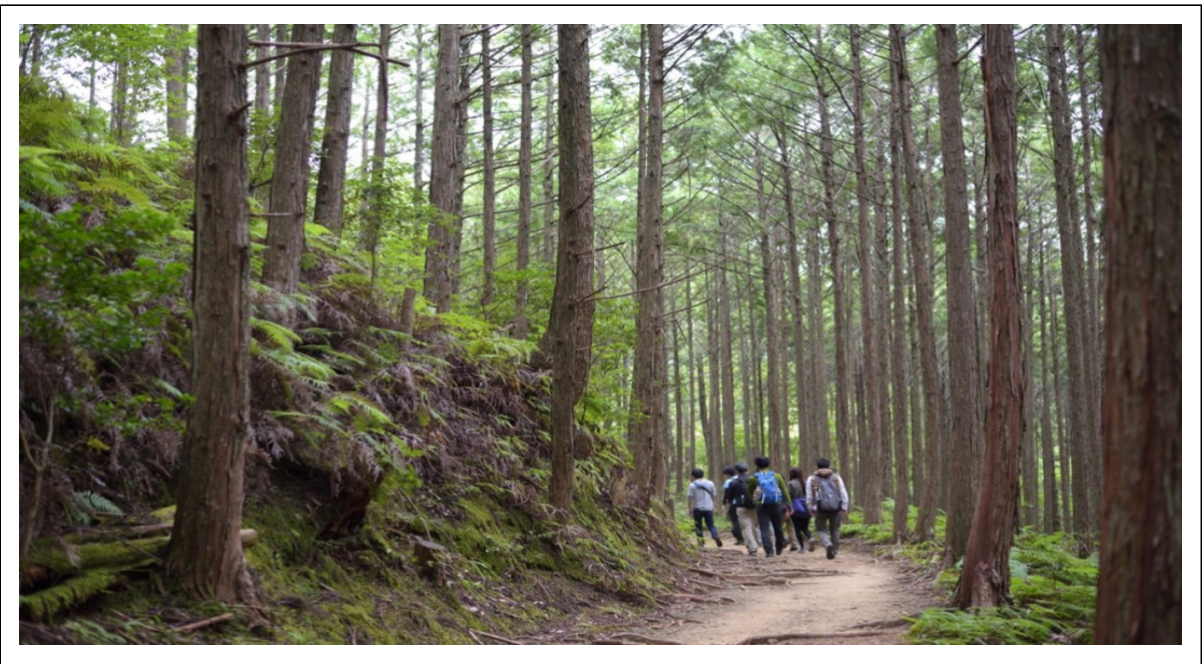

자료: https://wave.pref.wakayama.lg.jp/020400/workation/photo/photo.html

또한 이러한 워케이션 프로그램에 참가한 직원들은 회사 업무와 관광 활동 이외에 지 역주민들과의 교류에도 참여를 하여 지역과의 관계 맺기에도 노력한다. 지역 농가의 일 손 돕기 등의 발런티어 투어라든가 지역문제에 대한 합동 워크샵 등을 개최하여 단순히 오피스와 관광지에만 머물러 지역주민들과 유리되지 않도록 신경 쓰고 있다.

[그림 4-20] 일본 와카야마 워케이션 참가자들의 마을 돕기 모습

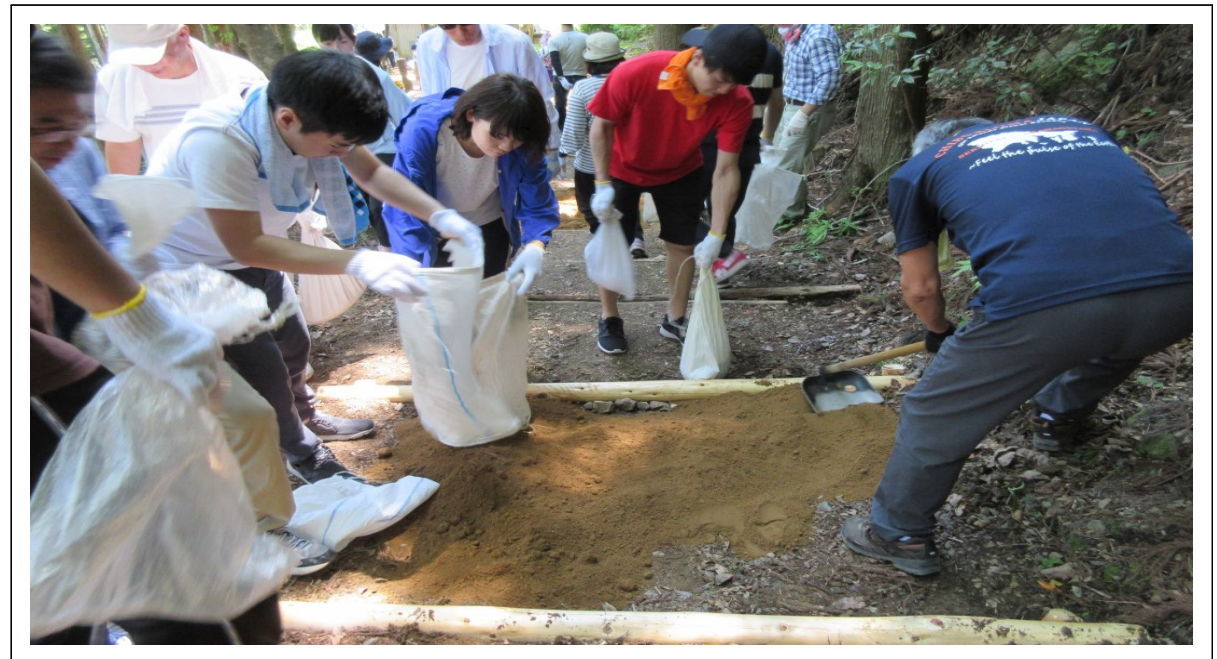

출처: https://wave.pref.wakayama.lg.jp/020400/workation/photo/photo.html 


\section{다. 워케이션 확산과 이해관계자 반응}

일본의 이러한 워케이션 확산에 대해서 이해 관계자들은 대부분 긍정적 반응이다.

일본 정부의 경우 오랫동안 노력해왔던 휴가 문화 개선과 일과 휴식의 균형에 워케이 션이 긍정적인 영향을 가져올 수 있다고 보고 있기 때문에 ‘관광전략실행추진회의'에서 다룰 정도로 적극 지원하는 입장이다. 일본 관광청이나 환경성, 농림수산성 등에서는 워 케이션을 추진하는 지자체나 사업체, 농가 등에게 워케이션 관련 인프라 개선 지원이나 숙소 리모델링 등을 할 경우 보조금을 지원하고 있다.

워케이션의 보다 직접적 이해관계자인 기업, 직장인 근로자, 지역도 호의적인 의견인 데 최근에 관광청에서 워케이션에 대해서 조사한 보고서에 따르면 다음과 같은 이유로 워케이션에 대해 긍정적 반응을 보이고 있다.

우선 워케이션을 도입한 기업은 유급 휴가의 사용촉진을 통해 휴가 보상에 대한 재정 적 부담도 경감할 수 있고, 사원들의 애사의식 향상, 지역사회 공헌 등으로 기업 이미지 개선 등의 효과가 있을 수 있어 역시 긍정적인 반응이다.

직장인 근로자들은 워케이션을 통해 그 동안 단기로 밖에 쓸 수 없었던 휴가의 장기 사용이 가능해지고, 출퇴근 스트레스에서 벗어날 수 있고, 업무 방식의 자율성과 유연성 이 증가하는 것에 대해 긍정적인 의견을 표하고 있다.

워케이션을 도입한 지역(지자체)의 경우 주말이나 휴가철에 몰리던 방문수요를 분산 시킬 수 있고, 워케이션 실시 기업과 지역과의 관계 맺기 및 교류 증가, 워케이션 관련 사업 활성화 및 유휴시설의 숙박시설 재활용 등을 통해 전반적인 지역활성화를 가져올 수 있어 역시 긍정적이다. 
〈표 4-7〉 일본 워케이션에 대한 이해관계자 멩 입장

\begin{tabular}{c|l}
\hline 구분 & \multicolumn{1}{|c}{ 내용 } \\
\hline 정부 & $\begin{array}{l}\text { 직장인 휴가 문화 개선 및 일과 휴식의 균형 확산/ 기업고용복지 및 지역활성화 정부 관련 정책 간접 } \\
\text { 효과 }\end{array}$ \\
\hline 기업 & $\begin{array}{l}\text { 휴가비 보상 부담 경감/ 귀사 의식의 향상/인재 확보 유출 억제/이노베이션 창출/기업 이미지 향상/ } \\
\text { 지역과의 관계성 구축으로 지방창생(지역활성화)에 기여 }\end{array}$ \\
\hline 직장인 & $\begin{array}{l}\text { 장기휴가의 취득촉진/ 업무 방식의 선택폭 증가/ 스트레스 경감/ 리프레시 효과/ 모티베이션의 향상 } \\
\text { / 업무효율의 향상/ 리모트 워크의 촉진/ 새로운 아이디어의 창출 }\end{array}$ \\
\hline 지역 & $\begin{array}{l}\text { 평일의 여행 수요 창출/ 교류 인구 또는 관계 인구 증가/ 관련사업의 활성화 또는 고용창출/ 기업과 } \\
\text { 의 관계성 구축/ 유휴시설 등의 새로운 활용 }\end{array}$ \\
\hline
\end{tabular}

자료: 일본 관광청 워케이션 조사보고서(2021), “新たな旅のスタイル(새로운 여행스타일)”, 연구자 부분 수정

다만, 아직까지 워케이션이 주로 IT 업종과 기업의 위성 오피스 유형에 집중되어 있 고, 일반 기업에는 많이 확산되지 못하고 있다는 것과 휴가형 워케이션(유급휴가를 떠나 서 휴가기간에 추가로 일을 하는 것)의 근무시간 산정, 코로나 19 이후 워케이션의 향방 등에 대해서는 좀 더 중장기적인 관찰과 노력이 필요한 과제로 꼽히고 있다. 


\section{제3절 소결}

\section{1. 우리나라 청년관광정책 동향 및 사례}

우리나라의 청년정책은 청년의 일자리 창출에 중점을 두고 시작되었으며, 이러한 정 책기조는 각 부처들의 청년정책에도 영향을 미쳤다. 이에 따라 청년관광정책도 일자리 창출에 중점을 두었는데 관광산업의 특성상 제조업처럼 전문기술 교육 등이 여의치 않 아 우리나라의 청년 관광정책은 창업을 독려하는 쪽에 중점을 두었다.

최근 문재인 정부에서 청년정책의 범위를 단순히 일자리 창출에서 벗어나 청년의 삶 전반으로 확대하면서 청년관광정책에서도 창업 이외 청년관광 수요 진작을 통한 국내관 광 활성화에도 관심을 가지기 시작하였다.

\section{가. 문화체육관광부(한국관광공사) 청년관광정책 사업}

문화체육관광부 현재 국내관광 활성화를 위해 실시하고 있는 청년관광 정책사업은 청 년관광 공모전(트래블리그), 청년층 갭이어(Gap Year), 대학생 유튜브 기자단(트래블리 더.mov)' 의 세 가지다. 이 사업들은 한국관광공사에서 사업 실무를 담당하여 진행되고 있는데 주로 청년들에 의한 여행 콘텐츠 개발과 그 내용을 다양한 SNS 채널 등을 통하 여 홍보하는 내용이다. MZ 세대의 특성에 맞추어 SNS 채널과 유투브를 통한 홍보 채널 등의 방식은 적정하지만, 동 사업들의 예산이 너무 적고 모두 홍보 마케팅 사업에 한정 되어 있다는 것이 한계다. 


\section{나. 지자체 청년관광정책 사업 및 기타}

특히 최근 체류형 여행이 각광 받으면서 국내 지방자치단체를 중심으로 관광객 유치 및 지역경제 활성화 목적의 한 달 살이 지원사업을 추진하고 있는 지자체가 증가하고 있다. 한 달 살이 지원사업은 경남, 전남, 충북 등 수도권 밖의 지자체에서 실시하였으며, 만 18 세 이상의 지역 외 거주자를 대상으로 30 일 이내의 숙박비와 지역시설 입장료 등 의 지역관광 체험비용을 지원하는 것이 주요 형태다. 이러한 체류형 여행 지원사업은 문화체육관광부의 사업과 달리 그 지원 대상을 청년층으로 한정하고 있지는 않다. 그러 나 선발과정에서 체험 후기의 SNS 정기적 게재를 지원 조건에 포함시킴으로써, SNS 활 용에 익숙한 청년층이 주로 선발되는 효과가 있다.

한편 코레일(KORAIL)에서는 청년층을 대상으로 일정기간 기차 무제한 이용패스인 ‘내일로 패스 YOUTH' 사업을 운영하고 있는데 코로나로 인한 청년들의 경제적 어려움 을 덜어주기 위하여 한시적으로 연령 범위를 2021년까지 만 34세까지로 확대하였다.

\section{2. 일본 청년관광정책 동향 및 사례}

일본은 우리나라 청년층과 다르게 청년층이 여행에 소극적이어서 국내외 분야를 가리 지 않고 정부 차원에서 일본 청년층의 여행을 적극 권장하고 있다. 일본 청년들이 여행 에 적극적이지 않은 현상에 대해 20-30대 일본 청년층은 일본의 버블경제 몰락으로 장 기 경제침체기(잃어버린 20년)에 태어나 소극적이며 미니멀 라이프를 추구하기 때문으 로 설명하고 있다. 저성장의 여파와 고용시장 불안, 불확실한 미래로 현재의 행복을 추 구한다는 점에서 '사토리' 세대는 MZ세대와 일맥 상통하지만 차이점은 '사토리' 세대는 소비에서도 소극적인 모습을 나타내는 차이점이 있다.

미래의 일본을 책임져야 할 일본 청년층들의 이런 태도에 대한 우려와 국내관광 시장 활성화를 배경으로 일본 정부에서 추진하고 있는 대표적인 청년관광 정책사업으로는 청 년여행 ‘와카타비(若旅)' 사업과 ‘워케이션(workation)' 사업을 들 수 있다. 


\section{가. '와카타비(若旅)' 사업}

'와카타비' 는 직역하면 '젊음여행(청춘여행') 이라는 의미다. 일본 관광청은 민간, 정 부, 학계로 구성된「청년여행진흥연구회(若者旅行振興研究会)」를 설치하고 청년들의 여 행 의욕을 고취시키기 위하여 적극적인 캠페인을 펼치고 있다. 또한 캠페인과 함께 청년 여행의 모범적인 사례를 선정하여 장관상을 수여하고 사례집을 펼쳐내면서 일본 청년들 이 여행에 좀 더 관심을 가지도록 노력하고 있다.

다행히 2018년부터는 일본 국내여행 동향에서 미약하지만 일본 청년층(20-39세)의 숙박 여행 경험률이 소폭 상승하여 일본 정부에서는 정책효과에 대하여 긍정적 평가를 내리고 있지만, 이러한 현상이 일시적인지 추세 전환에 의한 것인지에 대해서는 좀 더 관찰할 필요가 있다. 또한 일본 청년층의 국내여행에 대한 관심 상승이 정책효과인지 아니면 아베 정부의 무제한 양적완화에 의한 일본 소비경기의 일시적 상승에 의한 것인 지도 불분명한 측면도 있다. 아울러 양적완화로 엔화가치가 하락하면서 외국인들의 일본 여행이 증가하면서 일본 청년층들이 외국인 여행객들에 대한 접촉을 통하여 국내여행에 관심을 가지게 된 측면도 있는 것으로 추정하고 있다.

\section{나. ‘워케이션(Workation)' 사업}

'워케이션' 은 일(Work)과 휴가(Vacation)의 합성어로 휴가지(관광지)에서 일과 휴가 를 병행하는 형태를 가리킨다. 앞서 ‘와카타비’ 사업이 주로 정부가 주도하는 청년여행에 관한 캠페인 사업이었다면 ‘워케이션’ 사업은 일본 지자체가 먼저 시작하고 코로나19로 인하여 기업의 동참이 증가하게 된 경우다. 이 사업은 일본 청년층에만 특화된 사업이 아니지만, 사업의 특성상 IT 업종에 근무하는 청년층의 참여가 높은 특징이 있고, 정부, 기업, 근로자, 지자체의 다양한 이해관계자가 모두 수혜를 볼 수 있는 복합 효과가 있다.

코로나19 이후 일본기업들의 재택근무 확산과 맞물려서 워케이션에 대한 관심이 높 아지면서 일본 정부는 워케이션 확대를 적극 추진하고 있다. 특히 2020년 일본 관광전 략실행추진회의(우리나라의 국가관광전략회의에 해당함)에서 외케이션을 '새로운 여행 스타일 로 규정하고 주요 과제 중의 하나로 추진하고 있다.

워케이션은 기업과 근로자의 상황에 따라서 다양한 형태로 진행할 수 있지만, 일본에 서는 크게 휴가형, 업무형으로 구분하고 있으며 업무형은 다시 지역과제 해결형, 합숙형, 
위성 오피스형으로 나눠진다. 현재는 위성 오피스형이 주요 형태로 추진되고 있으며 일 본 와카야마현 시라하마쵸가 대표적인 지역이다.

현재는 IT 기업 업종에 주로 한정되어 있다는 한계가 있지만, 코로나19 확산과 일본 정부의 적극적인 지원, 일/휴가 정립을 위한 근로 문화 개선 노력 등과 맞물려 향후 점차 확대되고 관련 시장도 2025 년까지 약 5 배의 성장을 예상하고 있다. 

국내관광 활성화를 위한 청년관광 실태 분석 및 정책방안

제5장

청년관광 활성화 방안 



\section{제1절 연구결과 종합 및 기본방향 설정}

\section{1. 연구결과 종합}

본 장의 제 1 절에서는 청년관광 활성화를 위한 정책방안을 제시하기 전에 먼저 기본방 향설정을 위해 각장의 연구결과와 시사점을 정리하였다(〈표 5-1〉 참조).

〈표 5-1〉 연구결과 종합 및 시사점 정리

\begin{tabular}{|c|c|c|c|}
\hline 구분 & \multicolumn{2}{|r|}{ 연구결과 } & 시사점 \\
\hline \multirow[b]{3}{*}{$\begin{array}{l}\text { 청년 } \\
\text { 관광과 } \\
\mathrm{MZ} \text { 세대 }\end{array}$} & $\begin{array}{l}\text { 청년 } \\
\text { 정책 } \\
\text { 범위 }\end{array}$ & $\begin{array}{l}\text { - 청년에 대한 보편적 정의는 없으며 국가별 상황과 정 } \\
\text { 책목적에 따라 유동적임 } \\
\text { - 우리나라에서 정책대상으로서의 청년은 만 19세 34 } \\
\text { 세의 연령대에 있는 연령층을 가리킴 }\end{array}$ & $\begin{array}{l}\text { - 정책대상의 청년은 우리나라 총 } \\
\text { 인구의 약 } 20 \% \text { 에 해당하나 관 } \\
\text { 광정책에서는 관심을 받지 못함 }\end{array}$ \\
\hline & $\begin{array}{l}\mathrm{MZ} \\
\text { 세대 } \\
\text { 개요 }\end{array}$ & $\begin{array}{l}\text { - } \mathrm{MZ} \text { 세대는 국가별로 세대구분 연령에 약간 차이가 있 } \\
\text { 지만 각 국가 청년층의 핵심그룹에 해당 } \\
\text { - } \mathrm{MZ} \text { 세대는 개인주의 성향이 강하고 디지털 사용에 능 } \\
\text { 숙하며 현재의 행복을 추구 }\end{array}$ & \multirow{2}{*}{$\begin{array}{l}\text { - MZ세대 특성과 여행 행태에 부 } \\
\text { 합하는 정책 마련이 필요 } \\
\text { - 집단보다는 개인, 문자보다는 } \\
\text { 이미지, 오프라인 매체보다는 } \\
\text { 온라인 매체와 디지털에 대한 } \\
\text { 높은 의존도를 반영 } \\
\text { - 청년층에 대한 홍보 마케팅 방법 } \\
\text { 의 고도화 필요 } \\
\text { - MZ 세대의 디지털 이용도 과거 } \\
\text { 블로그에서 인스타그램, 유튜브 } \\
\text { 등으로 다변화 되고 영상화 되 } \\
\text { 어가는 경향을 고려하여 청년관 } \\
\text { 광 홍보 마케팅도 고도화기 필 } \\
\text { 요함을 알 수 있음 } \\
\text { - 코로나 } 19 \text { 로 국내여행 소비와 관 } \\
\text { 심이 증가한 } \mathrm{MZ} \text { 세대에 대한 정 } \\
\text { 책적 관심이 필요 } \\
\text { - 국내여행에 대한 관심 유지위한 } \\
\text { 정책적 노력 필요 }\end{array}$} \\
\hline & $\begin{array}{c}\mathrm{MZ} \\
\text { 세대 } \\
\text { 소비 } \\
\text { 문화 } \\
\\
\text { 및 } \\
\\
\text { 여행 } \\
\text { 트렌드 }\end{array}$ & $\begin{array}{l}\text { - MZ세대의 경제력은 이전 세대에 비해 낮지만 본인들 } \\
\text { 의 만족을 위한 소비에는 적극적 } \\
\text { - 일반 생필품(가성비) vs 취미생활(Flex:자기과시)의 } \\
\text { 이중적 소비행태 } \\
\text { - 코로나19로 MZ세대 소비트렌드가 다른 세대에까지 } \\
\text { 확대 } \\
\text { - MZ세대는 여행트렌드 주도 세대 } \\
\text { - 틀에 박힌 관광지가 아닌 새로움을 추구하는 활동적 } \\
\text { 세대 } \\
\text { - 문화체험 및 레포츠, 맛집 탐방 등 테마여행 } \\
\text { - 여행 전 정보수집 및 여행과정, 여행 후기 기록 등에 } \\
\text { 서 SNS를 적극적으로 활용 } \\
\text { - 코로나19 이후 MZ세대의 국내여행 증가 } \\
\text { - 코로나19로 국외여행이 불가능해지면서 여행욕구를 } \\
\text { 국내여행을 통해 발산 }\end{array}$ & \\
\hline
\end{tabular}


〈표 계속〉

\begin{tabular}{|c|c|c|c|}
\hline 구분 & & 연구결과 & 시사점 \\
\hline \multirow{4}{*}{$\begin{array}{c}\text { 청년층 } \\
\text { 국내관광 } \\
\text { 현황 } \\
\text { 및 } \\
\text { 특성 }\end{array}$} & $\begin{array}{l}\text { 여행 } \\
\text { 동향 }\end{array}$ & $\begin{array}{l}\text { - 청년층 국내여행 경혐율이 전체 국민 여행 경험률 } \\
\text { 보다 높음 (청년층: } 91.6 \% \text { > 전체 국민: } 86.4 \%) \\
\text { - } 1 \text { 인 평균 여행 횟수, 여행 일수, 평균 여행지 지출 } \\
\text { 도 전체 국민과 비교해 높음 } \\
\text { - 청년층이 전반적으로 여행활동이 활발하지만 세부 } \\
\text { 집단 별로 차이 } \\
\text { - 비경제활동 청년층의 경우 여행향유 격차 확대 }\end{array}$ & $\begin{array}{l}\text { - 여행에 가장 적극적인 세대 } \\
\text { - 코로나 } 19 \text { 로 관광활동이 전반적으로 } \\
\text { 위축되었지만 국내관광을 통해 관광 } \\
\text { 활동 지속 } \\
\text { - 향후 관광시장 회복과정에도 핵심적 } \\
\quad \text { 역할을 할 계층 } \\
\text { - 청년 여행 취약계층에 대한 정책적 관 } \\
\text { 심 필요 }\end{array}$ \\
\hline & $\begin{array}{l}\text { 여행 } \\
\text { 행태 }\end{array}$ & $\begin{array}{l}\text { - 여행정보 획득 경로: 온라인 매체 및 SNS 콘텐츠에 } \\
\text { 대한 선호도 높으며 단일 채널이 아닌 복수의 채널 } \\
\text { 을 활용 } \\
\text { - 디지털 매체를 통해 정보를 수집하고 다시 재생산 } \\
\text { - 여행 활동(Activities): 지역 특색을 나타내는 장소 } \\
\text { 및 체험 활동 선호 } \\
\text { - 새로운 여행지 및 다양한 여행체험 선호 } \\
\text { - 이동 수단: 여행의 자유로움 때문에 자가용을 주로 } \\
\text { 선호하나 경제적 요인에 따라서 대중교통도 이용 } \\
\text { - 코로나 } 19 \text { 로 여행안전에 대한 우려로 자가용 이용 } \\
\text { 더욱 증가 }\end{array}$ & $\begin{array}{l}\text { - 청년여행 정보제공 및 홍보 방법 정교 } \\
\text { 화 필요 } \\
\text { - 인스타그램 등 선호 SNS를 활용하 } \\
\text { 는 방법에 대한 고민 필요 } \\
\text { - 청년여행 행태를 고려한 상품 개발 } \\
\text { - 독특한 체험, 그 장소에서만 가능한 } \\
\text { 체험 관광상품 개발 } \\
\text { - 자가용 활용 증가에 대한 정책사업 } \\
\quad \text { 반영 }\end{array}$ \\
\hline & $\begin{array}{l}\text { 여행 } \\
\text { 제약 } \\
\text { 요인 }\end{array}$ & $\begin{array}{l}\text { - 국내여행 제약 주요 요인 } \\
\text { : 시간 부족, 인프라 불편, 경제적 여유 부족 } \\
\text { - 시간 부족: 직장인 청년집단에게 가장 큰 제약요 } \\
\text { 인이며 휴가사용이 어려운 직장분위기가 큰 원인 } \\
\text { - 인프라 불편: 여행 목적지 내에서의 이동, 즉 교통 } \\
\text { 인프라에 대한 불편사항이 가장 큰 제약 } \\
\text { - 경제적 여유 부족: 비경제활동 인구의 경우 부모/ } \\
\text { 친지 등으로부터 경비 지원을 통해 여행경비에 대 } \\
\text { 한 부담 }\end{array}$ & \multirow{2}{*}{$\begin{array}{l}\text { - 국내여행 제약 주요 요인 경감을 위한 } \\
\text { 정책방향 수립 } \\
\text { - 시간부족 해소: 직장인 대상 방안 마 } \\
\text { 련 필요 } \\
\text { - 교통 인프라 불편: } \\
\text { 관광지 내 이농불편 해소방안 } \\
\text { - 경제적 여유 부족: 경제적 취약 청년 } \\
\text { 계층을 위한 방안 마련 }\end{array}$} \\
\hline & $\begin{array}{l}\text { 주요 } \\
\text { 개선 } \\
\text { 희망 } \\
\text { 분야 }\end{array}$ & $\begin{array}{l}\text { - 국내여행 활성화를 위한 주요개선 희망분야 } \\
\text { : 상품개발, 서비스, 인프라 구축 등 } \\
\text { - 상품개발 및 서비스: 민간 역할 중요 } \\
\text { - 인프라 구축: 공공 역할 중요 } \\
\text { - 청년 세부집단 별로 개선희망 순위 차이 } \\
\text { - 직장인: 근로자휴가지원사업, 유연근무제 확대 시 } \\
\text { 행 등 } \\
\text { - 대학생: 여행경비 지원 등 }\end{array}$ & \\
\hline
\end{tabular}




\section{2. 청년관광정책 기본방향 설정}

〈표 5-1〉의 연구결과 및 시사점을 바탕으로 다음 청년관광 인프라, 청년관광 관련 제 도, 청년관광 홍보 및 콘텐츠 고도화의 세 가지 정책 기본방향을 설정하였다

\section{가. 세부집단 수요를 반영한 청년관광 제도 개선}

우리나라 청년관광 실태 및 특성 분석 결과에서 나타난 것처럼 청년층은 공통적으로 나타나는 여행 동향들도 있지만, 세분집단에 따라 약간씩 차별을 보이는 부분도 있었다. 따라서 청년 전체에 공통적인 정책방안 뿐 아니라 각 세분집단(sub-group)에 부합하는 제도적 개선을 마련해야 좀 더 높은 정책방안의 효과를 기대할 수 있을 것이다. 예를 들어 직장인 청년층에 대해서는 휴가 사용을 좀 더 원활하게 할 수 있고 촉진시킬 수 있는 지원방안을 마련하고, 비경제 활동으로 경제적 부담이 어려운 청년층에게는 여행경 비 지원을 할 수 있는 제도적 방안이 필요하다.

\section{나. 청년관광 행태를 반영한 홍보 전략 개선}

$\mathrm{MZ}$ 세대 청년층의 여행 특징과 설문조사에서도 나타난 것처럼 청년층의 국내여행은 디지털 콘텐츠와 SNS 채널에 대한 의존도가 높게 나타났다. 전통적인 미디어인 TV 나 종합 포털 사이트의 이용도보다 인스타그램, Youtube 등의 새로운 채널이 부각하고 있 으며 이미지 정보에 대한 반응이 크다. 그러므로 청년들의 이러한 관광행태와 취향을 반영한 홍보전략 수단을 수립할 필요가 있다.

\section{다. 청년관광 불편사항 경감을 위한 인프라 개선}

청년층은 여행지내에서의 이동과 숙박비 등에 대해서 큰 제약을 느끼고 있었다. 또한 영유아 자녀를 동반하여 여행을 하는 기혼 청년층은 숙소의 안전과 위생 부분에 대한 염려가 컸다. 따라서 청년층의 주요 국내관광 제약요인인 관광 목적지 내에서의 교통, 영유아 등을 배려한 가족 친화 환경 조성, 깨끗하고 안전한 숙박 시설 등 관련 인프라 개선을 통해 청년들의 국내관광 편의성을 제고하고 국내관광 활성화를 유도하여야 한다. 


\section{제2절 청년관광 정책방안}

\section{1. 청년관광 제도개선}

\section{가. 근로자 휴가지원 사업 지역연계 확대}

1) 추진배경

설문조사 결과 청년층이 희망하는 추진 필요 정책에서 근로자 휴가지원 사업 확대는 가장 높은 순위를 기록하였다. 참여기업, 근로자, 정부가 공동으로 여행자금을 적립하고 이를 근로자가 국내여행에 이용하는 근로자 휴가지원 사업은 국내 여행 관련하여 신규 수요 창출 및 국내여행에 대한 인식개선에 긍정적인 효과를 가져 온 것으로 평가되었다 (한국관광공사, 2020)

[그림 5-1] 근로자 휴가지원사업 국내여행 신규 수요창출 효과

\section{3. 참여근로자 조사결과}

\section{다. 신규 수요 창출}

- 당초여행계획이없었으나근로자휴가지원사업을통해여행을다녀온근로자는 $58,5 \%$ 로, $58.5 \%$ 의신규수요가창출된것으로나타남

- 근로자휴가지원사업의신규수요창출은2014년시범사업 이후매년증가하는추서를보임

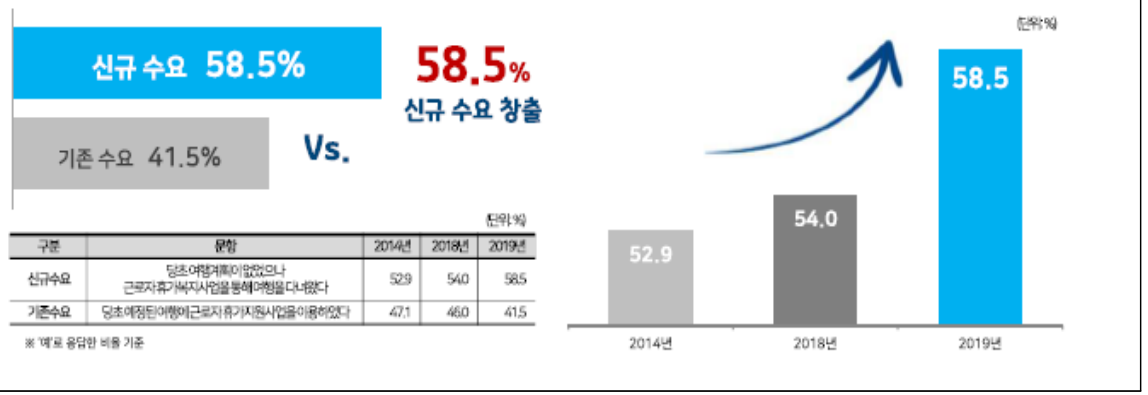

자료: 한국관광공사(2020), 「근로자휴가지원사업 성과분석 및 발전방안연구」, 


\section{3. 참여근로자 조사결과}

\section{아. 인식 조사: 국내여행에 대한 인식}

- 근로자휴가지원사업에참여함으로써근로자들의국내여행에 대한인식이긍정적으로 변화된것으로나타남

- 특히, 응답자의 $87.3 \%$ 가사업 침여로 인해 국내새로운 지역에 대한 관광욕구가증가하였고, 국내여행에 대한관심이증가했고( $81.0 \%)$, 국나여행에대 한긍정적인식이중가(79,5\%)한것으로나타남

$87.3 \%$

새로운 지역 관광욕구 증가

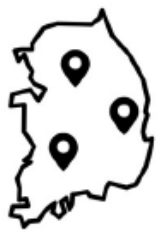

$81.0 \%$ 국내여행 관심 증가

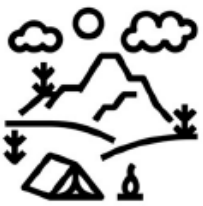

$79.5 \%$ 국내여행 긍정적 인식

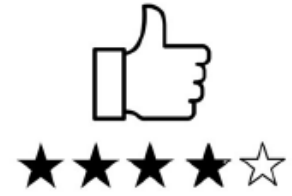

자료: 한국관광공사(2020), 「근로자휴가지원사업 성과분석 및 발전방안연구」,

2) 추진내용

근로자 휴가지원 사업이 국내여행 활성화 및 직장인 휴가문화 개선에 긍정적인 효과 가 있음에도 불구하고, 현재 근로자 휴가지원 사업의 혜택을 보는 비중은 전체 중소기업 근로자의 $0.5 \%$ 에 불과하다. 15$)$ 따라서 한국관광공사의 2020년 사업 평가보고서에서는 동 사업의 확장을 위하여 관련 부처 및 지자체와의 협력 모델을 제시하였는데 이 중 국 내관광 활성화 측면에서 지자체의 관광객 지원 사업과 근로자 휴가지원사업을 연계하는 방안이 참고할 필요가 있다.

이 방안은 해당 지자체의 관광상품을 근로자 휴가지원사업에 참여하는 근로자가 구입 할 경우 지자체에서 추가 지원을 하는 것이다. 참가 근로자들은 여행경비의 추가 지원으 로 경비 부담을 좀 더 덜 수 있고, 해당 지자체는 근로자 여행객들의 지역 방문을 독려하 여 지역관광 활성화에 도움이 되게 할 수 있다. 현재는 강원도와 경상북도에서만 시행16) 하고 있는데 이를 시도관광국장회의와 연계하여 다른 지자체로도 확대할 수 있게 추진 한다. 이를 위해 지역협의체를 구성하고 문체부에서는 지자체별로 산발적으로 운영되는

15) 2020년 사업 기준

16) 2020년 사업의 경우 경상북도는 근로자들이 경북 관광상품을 구매 할 경우 최대 10 만원, 강원도는 최대 5 만원의 추가 할인혜택을 제공함 
유사사업 모델을 통합 조정하고, 지자체에서는 지역관광 상품 발굴 및 홍보를 담당할 수 있게 한다(한국관광공사, 2020).

〈표 5-2〉 근로자 휴가지원 사업 확대를 위한 지자체 협력방안

$$
\text { 주요 내용 }
$$

- 추진방향: 근로자 휴가지원사업과 지자체 지역방문 관광객 지원 사업을 연계

- 강원도 \& 경상북도 모델을 타 지자체로 확대

- 정부와 지자체간 지원경비 공동부담을 통해 지원대상 확대 및

- 국내관광 활성화 및 지역관광 활성화 도모

- 추진방법: 광역지자체 중 근로자 휴가지원 사업 협력 의향 지자체를 중심으로 실시

- 시도 관광국장회의를 통해 정례적 논의 및 협의

- 문체부는 유사사업모델 통합 및 조정 유도

- 지자체는 지역 관광 콘텐츠 및 상품개발 및 홍보

자료: 한국관광공사(2020), 「근로자휴가지원사업 성과분석 및 발전방안연구」, 연구자 수정

\section{나. 워케이션 시범사업 추진}

\section{1) 추진배경}

연구조사 결과 청년층의 국내여행 주요 제약요인 중 하나는 여행을 할 시간 여유가 없다는 것이었다. 이는 특히 직장인 청년계층에서 여행을 제약하는 요인이었으며 구체적 으로는 '휴가를 마음대로 사용하기에 어려운 직장 분위기' 가 그 세부 요인으로 꼽혔다. 문재인 정부에서는 일과 휴식의 균형을 강조하고 우리나라도 제 1 차 국가관광전략 회의 에서 "심표가 있는 삶“ 이라는 구호를 내세웠지만 여전히 직장인들의 자유로운 휴가 사 용은 쉽지 않은 문제임을 알 수 있다. 그러므로 직장인들의 휴가 사용 촉진과 함께 그것 을 보완할 수 있는 방법으로 우리나라도 현재 일본에서 확산 중인 '워케이션' 제도에 대 해서 우리도 도입을 검토해볼 필요가 있다.

실제로 얼마 전 강원도 관광재단은 국내 한 여행사와 협력하여 강원도를 대상으로 워 케이션 관광상품 기획전을 시행한 적이 있었다. 이 사업의 목적은 강원도의 주중 관광을 활성화시키고 코로나로 침체된 강원도 관광지 지역 경제 활성화를 위한 것이었는데, 여 행자들이 여행상품을 구입한 후에 개인 인스타그램에 필수 해시태그 및 사진 업로드시 에 지역 상품을 구입할 수 있는 모바일 강원상품권을 지급하는 인센티브를 제공하였다. 또한 해당상품을 판매하는 여행사들은 강원도 지역호텔 및 리조트들과 함께 객실 업그 
레이드, 비즈니스 라운 지용 등의 프로모션을 펼쳤다. 이 워케이션 상품 기획전은 출시 후 주중 숙박이 같은 기간보다 $25 \%$ 이상 증가 3 박 이상 예약이 $13 \%$ 이상 증가, 고성군 의 경우 전년 동기 주중 숙박 $97 \%$ 이상 증가의 성과를 가져온 것으로 알려졌다. 17$)$

[그림 5-3] 강원도 워케이션 관광상품 홍보 포스터

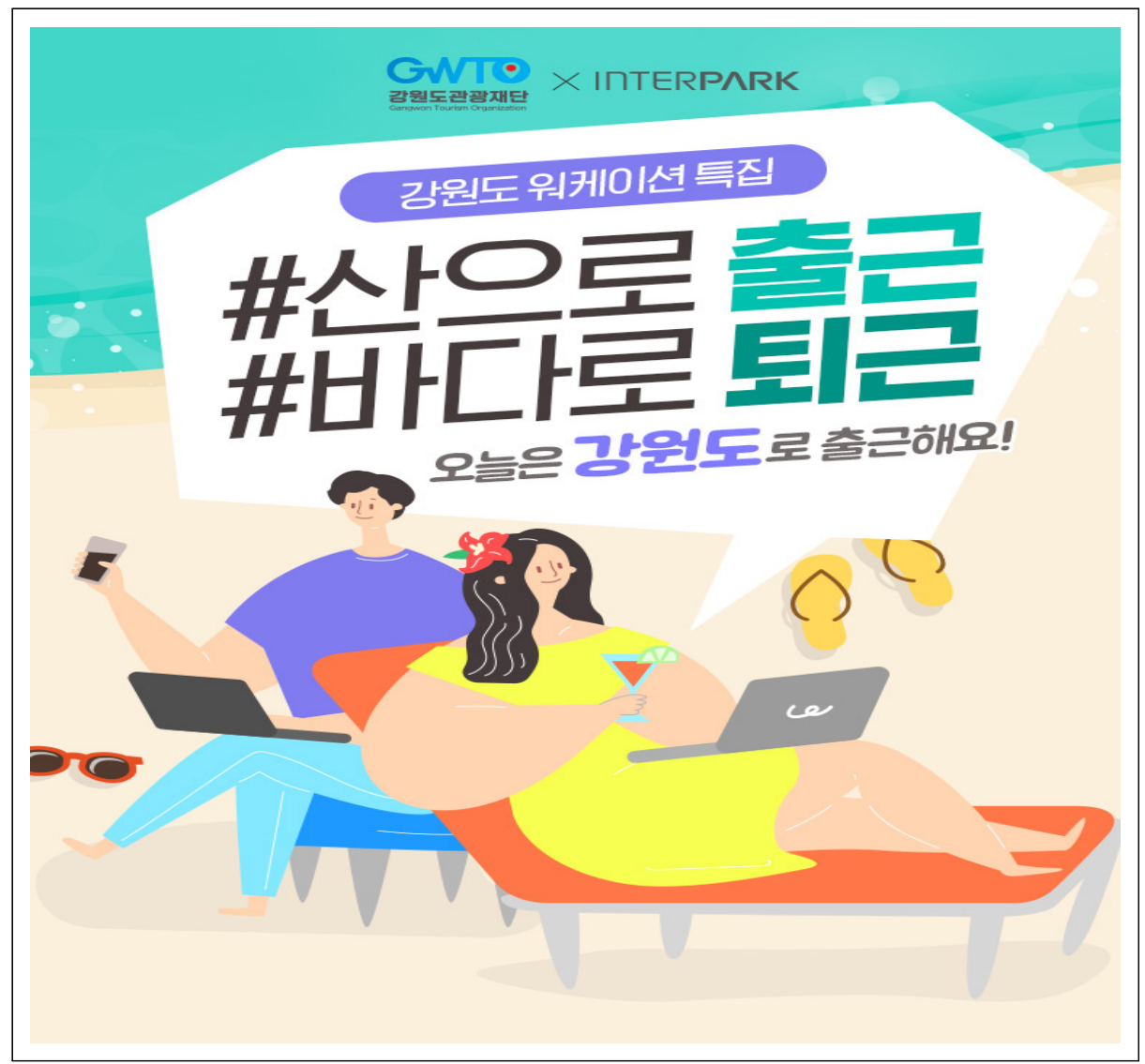

자료: 강원관광재단(http://gwto.or.kr/) 보도자료

그러나 실제로 강원도 워케이션 여행 상품을 구입한 소비자들이 워케이션을 위하여 구입한 직장인 근로자인지에 대한 분석은 실시하지 않아서 단순히 일반 여행객들이 할 인 프로모션을 노린 것인지, 아니면 직장인 근로자들의 워케이션에 대한 수요였는지는 정밀하게 분석하지 못한 한계가 있다.18)

17) 강원도 관광재단 보도자료

18) 강원도 관광재단 워케이션 사업 담당자 통화를 통해 확인 


\section{2) 추진방안}

에어비앤비가 2020년에 실시한 여행트렌드 조사에 따르면 한국인 응답자의 61\%가 워케이션을 시도해볼 의향이 있다고 밝혔다.19) 따라서 근로자들의 워케이션에 대한 잠 재적 수요는 우리나라에도 있을 것으로 추정해볼 수는 있다. 또한 우리나라 김해시에서 는 김해 지역 체류여행 선발 時, 워케이션 참여 가능자 우대 조건을 제시하고 있어 일부 지자체에서도 워케이션에 대한 초기적 관심은 있다는 것을 알 수 있다.

\section{〈표 5-3〉 근로자 휴가지원 사업 확대를 위한 지자체 협력방안}

\begin{tabular}{|c|c|}
\hline 구분 & 내용 \\
\hline 필수사항 & $\begin{array}{l}\text { - (지역성) 경남지역 외 거주자로 만 19세 이상 여행에 관심이 많은 자 } \\
\text { - (홍보력) SNS(유튜브, 인스타, 페이스북 등) 운영이 가능한 자 } \\
\text { - (충실성) 김해 여행의 구체화 및 충실한 자 } \\
\text { - (이해력) Gimhae live \& life(요즘김해, 지금여행) 사업 취지를 충분히 이해한 자, 여행 중 } \\
\text { 홍보 미션 수행이 가능한 자. 초상권 및 콘텐츠 저작권 귀속이 가능한 자 }\end{array}$ \\
\hline 우대사항 & $\begin{array}{l}\text { - (청년특별도 연계성) 경남도 핵심과제와의 연계를 위해 청년(만19 만34세) 우대 } \\
\text { - (홍보특화성) SNS 활동이 활발하며, 온라인 상 높은 영향력을 가진 자 우대 } \\
\text { - (적극성) 우리시에 대한 강한 호기심과 알고자 하는 열망이 높은 자 우대 } \\
\text { - (특별성) 재직증명서, 재택근무확인서 등 워케이션 참여 가능 자 우대 }\end{array}$ \\
\hline
\end{tabular}

자료: 김해시2020), 지역체류형 관광지원 프로그램 「요즘 김해 지금 여행」 안내문 발췌, 수정

그러나 워케이션을 실시하는데 있어 가장 큰 영향력을 행사할 이해관계자인 우리나라 기업들이 워케이션 제도를 받아들일 준비가 되어 있는지에 대해서는 알려진 바가 거의 없고. 근로자, 지자체, 중앙 관련부처 워케이션 관련 이해 관계자들의 입장에 대해서도 좀 더 세밀한 연구가 필요하다.

이후 연구결과를 바탕으로 워케이션 시범사업을 추진할 수 있을 것인데, 추진방식과 유형은 기업과 근로자들의 수요에 따라 진행한다. 지자체의 경우에는 일본 지자체들처럼 해당 지자체에 워케이션 근무가 용이한 원격 근무 인프라를 구축하고 이에 대한 홍보 등을 담당하며 문체부는 이에 대해 일부 지원을 담당할 수 있다.

또한 워케이션 사업을 기 시행 중인 근로자휴가 지원사업과 연계하는 방안도 검토해 볼 필요가 있다. 예를 들어 일본의 휴가형 워케이션 사업처럼 유급 휴가 사용기간 중에 도 일정 시간 업무 후에 회사에 보고하면 이를 정상 근무로 인정해주는 것이다. 20)

19) https://news.airbnb.com/ko/2021-travel-trends/ "2021년 여행 트렌드: 원격근무와 원격 교육 등 으로 일과 여행, 주거가 혼합될 것" 


\section{다. 청년 문화누리카드 도입 및 확대}

\section{1) 추진배경}

연구조사 결과, 청년층의 국내여행을 제약하는 또 다른 요인은 경제적 부담이다. 특히 이는 비경제 활동 청년층의 주요 제악요인으로 나타나고 있어 청년층 사이에서도 관광 활동에 대한 경제적 차별화가 나타나는 것을 알 수 있다.

현재 문화체육관광부(한국문화예술위원회).에서 경제적 취약계층의 문화관광체육 활 동 생활을 지원하기 위해 실시하고 있는 '문화누리카드' 사업은 기초생활수급자와 차상 위 계층을 대상으로 하고 있다.

〈표 5-4〉현행 문화누리카드 사업 개요

\begin{tabular}{l}
\hline 주요 내용 \\
\hline - 사업대상자(2021년 기준) \\
- 기초생활수급자 및 차상위 계층(6세 이상, 2015.12.31 이전 출생자) \\
- 기초생활수급자: 생계, 의료, 주거, 교육급여 수급자, 조건부 수급자, 보장시설 수급자 \\
- 법정차상위계층: 차상위자활근로자, 장애수당 수급자, 장애아동수당 수급자, 장애인연금 부가급여 수급자 \\
(차상위초과자 제외), 본인부담경감대상자, 저소득한부모가족, 차상위계층확인서 발급자(구 우선돌봄차상위), \\
교육급여 수급자(학생) 외 나머지 가구원 \\
- 지원금액: 1인당 연간 10만원 지원 \\
- 사용분야: 공연 · 영화 · 전시 관람을 비롯해 국내 여행, 4대 프로스포츠 관람 \\
$\quad$ (축구, 농구, 야구, 배구) 등
\end{tabular}

자료: 문화누리사업 홈페이지(http://www.mnuri.kr/munhwa) 발췌, 연구자 정리

문화체육관광부는 2022년부터 모든 저소득층 경제적 어려움으로 문화생활이 저해되 지 않도록 모든 저소득층(기초·차상위계층) 청년에게 문화누리카드(年10만원) 지급을 목 표로 하고 있다.21)

\section{2) 추진방안}

현재 문체부가 청년 문화누리카드 도입을 계획하고 있지만 아직 확정된 것은 아니다. 따라서 우선적으로는 2022년부터 계획대로 청년 문화누리카드 도입이 순조롭게 되도록

20) 일본항공(JAL: Japan Air Line)은 연간 최대 5일까지 휴가지에서의 업무 시간을 정산근무로 인정해주고 있음

21) 제1차 청년정책기본계획(2020), 청년문화활동 기반강화 과제로 제시 
추진하는 것이 필요하다.

그리고 도입이 된 이후에는 그 지원 대상을 확대시킬 필요가 있다. 현재의 문화누리카 드는 기초생활수급자와 차상위 계층으로 그 대상을 한정하고 있어서 이 대상범위를 따 를 경우 여기에 해당하지 못 하는 청년계층의 경우 정책대상에서 소외될 우려가 있다. 그러므로 청년 문화누리 카드 도입 후 사업의 효과성을 분석하여 그 결과가 긍정적으로 나올 경우 지원 대상을 청년층 전체로 넓히도록 한다. 청년기본법에서도 명시하고 있는 것처럼 청년의 문화향유에 대한 것은 국가의 책무이다.22) 따라서 청년의 문화활동에 대 한 지원은 복지적 개념이 아니라 청년의 기본권적인 관점에서 접근하여야 한다.

\section{2. 청년관광 홍보전략 개선}

\section{가. 청년 관광 인스타 100 선 선정}

1) 추진배경

현재 정부는 많은 예산을 투입하여 TV, 라디오, 대형 유통업체 등과 연계한 대중 광고 를 불특정 다수를 대상으로 송출하고 있다. 그러나 본 연구에서 추진된 청년층 인터뷰 결과 해당 방식으로 송출된 정부의 국내관광 정보에 대한 청년층의 인지도는 매우 낮은 수준 것으로 드러났다.

청년층은 전체 국민과 비교하여 정보획득 시 인터넷/스마트폰 등에 대한 이용률이 상 대적으로 높으며, 디지털 매체를 통해 여행후기를 활발히 공유하는 등 여행정보에 대한 공유와 소통을 중요시 하는 행태를 보이고 있다. 특히 청년층은 인터넷/스마트폰 등 매 체 활용의 특성뿐만 아니라 '관광 매력물의 사진과 해시태그로 구성된 SNS 콘텐츠'와 같이 특정 형식의 디지털콘텐츠에 대한 선호를 함께 드러내었다. 따라서 청년층의 디지 털 매체( 및 콘텐츠) 활용의 특성을 고려하여 청년층이 선호하는 국내 관광지와 매력물 을 홍보함으로써 보다 효과적으로 정보를 전달할 필요성이 있다.

22) 청년기본법 제23조(청년 문화활동 지원) '국가와 지방자치단체는 청년의 다양하고 창의적인 문화 활동을 지원하기 위한 대책을 마련하여야 함' 


\section{2) 추진내용}

본 사업은 청년층을 대상으로 공모를 통해 '(가칭) 청년 관광 인스타 100 선'을 선정하 는 것으로 시작한다. 콘텐츠의 유형은 청년층이 선호하는 '관광 매력물의 사진과 해시태 그로 구성된 SNS 콘텐츠'로 하며, 청년층이 여행지 선택 시 주로 고려하는 지역의 먹거 리, 예쁜 사진찍기 좋은 장소 등을 주제로 하여 추진한다. 선정된 콘텐츠를 대상으로 '\# 청년 관광 인스타 100 선' 해시태그를 부여하며, 문화체육관광부 및 유관기관은 ‘\#청년 관광 인스타 100 선 해시태그를 중심으로 청년층 대상 홍보와 이벤트를 진행한다.

본 사업 방식의 핵심적인 기대효과는 SNS 채널의 특성에 따른 확장 가능성에 있다. 인스타그램은 해시태그를 중심으로 콘텐츠에 대한 접근이 이루어지며 연계 콘텐츠로의 무한한 접근 가능성을 제공한다. 따라서 문화체육관광부는 본 사업을 통해 우수한 청년 관광 콘텐츠를 확보할 뿐만 아니라 인증 콘텐츠를 통해 해당 채널에서 노출되고 있는 다수의 연관 콘텐츠를 잠재 관광객이 구독하도록 유도할 수 있다.

[그림 5-4] (가칭) 청년 관광 인스타 100선 공모 및 확산 과정

\begin{tabular}{|c|c|c|c|}
\hline 서류접수 & 서류 심사 & 콘텐츠 노출 & 홍보 \\
\hline $\begin{array}{c}\text { 공모전 참가 } \\
\text { 지원서 접수 } \\
\text { * 지원서 형태: } \\
\text { 관광 매력물의 } \\
\text { 사진과 해시태그로 } \\
\text { 구성된 SNS } \\
\text { 콘텐츠 }\end{array}$ & $\begin{array}{c}\text { 지원서 검토 및 } \\
\text { 서류합격자 선발 } \\
\text { * } 100 \text { 개 콘텐츠 } \\
\text { 선발 예정 }\end{array}$ & $\begin{array}{l}\text { 선정된 콘텐츠 } \\
\text { 대상 “\# 청년 관광 } \\
\text { 인스타 100선” } \\
\text { 해시태그 부여 및 } \\
\text { 지원자 계정을 } \\
\quad \text { 통해 게시 }\end{array}$ & $\begin{array}{l}\text { 청년 관광 인스타 } \\
100 \text { 선 사업 및 } \\
\text { “\# 청년 관광 } \\
\text { 인스타 } 100 \text { 선” } \\
\quad \text { 홍보 }\end{array}$ \\
\hline 유입 & \multicolumn{3}{|c|}{ 확장 } \\
\hline $\begin{array}{c}\text { 청년 잠재 관광객 } \\
\text { "\# 청년 관광 } \\
\text { 인스타 } 100 \text { 선" } \\
\text { 검색 및 구독 }\end{array}$ & \multicolumn{3}{|c|}{$\begin{array}{c}\text { “\# 청년 관광 인스타 100선" 콘텐츠를 통해 연관 콘텐츠 정보 지속 노출 } \\
\text { 〈예시〉 “\# 청년 관광 인스타 100선”을 통해 강릉 커피거리 관련 콘텐츠 } \\
\text { 최초 구독 =〉 콘텐츠 내 강릉 커피거리 관련 해시태그 및 연관 콘텐츠 } \\
\text { 추천을 통해 '강릉 커피거리' 콘텐츠에 지속 노출 }\end{array}$} \\
\hline
\end{tabular}




\section{나. 지역 관광 $\mathrm{TV}$ ‘라이브 방송’ 지원}

1) 추진배경

정부는 여행주간, 근로자휴가지원사업 등 추진 중인 국내관광 활성화 사업 홍보에 많 은 예산을 투입하고 있으나, 본 연구 결과에 의하면 TV, 라디오와 같은 대중매체를 통해 노출된 정보에 대한 청년층의 인지도는 매우 낮은 실정이다.

이에 문화체육관광부는 청년층 갭이어 사업, 대학생 유튜브 기자단 등의 사업을 추진 하고 있으나, 현재 SNS와 연계한 홍보 - 마케팅 사업은 콘텐츠를 통해 잠재 관광객과 소 통하기 보다는 콘텐츠 작성 역량을 갖춘 청년을 선발하여 콘텐츠 제작 및 송출을 유도하 는 사업 방식을 근간으로 하고 있다.

그러나 청년층은 송출되는 정보를 일방적으로 수용하는 것 보다는 양방향 소통을 통 해 정보를 획득하고 공유하는 것을 중요하게 여기는 것으로 알려져 있으며, 이런 추세에 맞춰 '라이브 방송' 형태의 콘텐츠가 다양한 분야에서 정보 제공의 수단으로 각광 받고 있다. 따라서 청년층의 디지털 정보 및 소통을 선호하는 특성을 고려하여 '(가칭) 지역 관광 TV ‘라이브 방송 지원 사업’의 추진을 고려할 필요성이 있다.

\section{2) 추진내용}

본 사업의 추진은 지자체와 인플루언서의 참여를 근간으로 하며, 문화체육관광부는 지자체가 기획한 라이브 방송 중 우수한 기획을 선정하여 방송의 제작 및 송출에 필요한 절차를 지원하는 사업이다.

'라이브 방송' 방식의 정보 제공은 인플루언서가 참여한다는 점에서 방송 그 자체로서 화제성이 있으며, 방송 종료 이후에도 동영상 스트리밍 서비스(유튜브, 아프리카tv 등)를 통해 반복적으로 노출을 이어나갈 수 있다. 또한 양방향 소통을 위해 지역의 전문가 참 여가 필수적이며, 지자체에서 주도적으로 지역의 관광 매력물을 홍보할 수 있다는 장점 이 있다. 
[그림 5-5] (가칭) 지역 관광 TV '라이브 방송' 지원 사업 추진 과정

\begin{tabular}{|c|c|c|c|}
\hline 서류접수 & 서류 심사 & 방송 제작 & 확산 \\
\hline $\begin{array}{c}\text { 공모전 참가 } \\
\text { 지원서 접수 } \\
\text { * 지원서 형태: } \\
\text { 지역 관광 } \\
\text { 매력물을 홍보하기 } \\
\text { 위한 라이브방송 } \\
\text { 기획서(지자체) }\end{array}$ & $\begin{array}{l}\text { 지원서 검토 및 } \\
\text { 우수 기획안 선발 } \\
\text { * 20개 내외 } \\
\text { 콘텐츠 선발 예정 }\end{array}$ & $\begin{array}{c}\text { 선정된 기획안을 } \\
\text { 바탕으로 } \\
\text { 인플루언서 섭외, } \\
\text { 방송제작 및 송출 } \\
\text { 지원 }\end{array}$ & $\begin{array}{c}\text { ‘라이브 방송’ } \\
\text { 활용 2차 콘텐츠 } \\
\text { 생산 및 공공 } \\
\text { SNS 채널 활용 } \\
\text { 노출 }\end{array}$ \\
\hline
\end{tabular}

\section{다. 메타버스 연계 지역관광 홍보·마케팅 지원}

1) 추진배경

메타버스(Metaverse)는 가상, 초월을 뜻하는 메타(Meta)와 세계를 뜻하는 유니버스 (Universe)의 합성어로 아바타가 존재하는 3차원의 가상세계를 의미한다. 코로나19로 인한 비대면 문화의 확산은 각 분야의 가상세계를 통한 상호작용 확대를 촉진하고 있으 며, 관광분야에서도 필수적인 마케팅 수단으로 주목받고 있다.

본 연구의 결과 청년층은 전체적인 여행 참여 빈도가 높고 국내관광 시장을 주도하는 계층이다. 특히, 코로나 19 의 영향으로 국내관광 활동의 크게 위축된 상황에서도 관광여 행 중심의 국내관광 활동을 지속적으로 이어가는 등 코로나 19 이후 국내관광 시장을 주 도하는 핵심 계층으로 자리매김하고 있다. 그러나 청년층 내에서도 영유아 동반 가구, 경제적 취약 계층 등 일부 집단은 코로나 19 의 영향으로 인해 국내관광 활동이 크게 위축 된 모습을 나타내기도 하였다. 코로나19 종식 이후 국내관광 시장의 탄력적 회복을 위해 서는 관광활동 취약계층을 포함한 청년층 전체의 국내관광 참여를 독려하고, 국내관광에 대한 경험을 지속적으로 공유하는 기회를 제공할 필요성이 있다.

따라서 본 절에서 반복적으로 제시한 바와 같이 청년층의 인터넷/스마트폰 및 디지털 콘텐츠 선호 특성을 고려할 때 '메타버스를 활용한 지역관광 홍보 - 마케팅 지원'사업은 국내관광 활성화 측면에서 상당한 효과를 기대할 수 있는데. 본 사업의 추진 효과는 다 음의 추진내용과 연계하여 구체적으로 기술하고자 한다. 


\section{2) 추진내용}

본 사업의 특징은 비대면 지역관광 마케팅을 강화하고 가상세계 속 아바타를 통해 상 호작용 할 수 있는 콘텐츠를 제공하는데 있다. 본 사업은 지역 관광목적지가 메타버스 플랫폼과 연계하여 청년층을 대상으로 홍보 - 마케팅을 제공하는 것을 목적으로 한다. 지 자체는 경포대 해수욕장, 불국사, 무령왕릉, 통영케이블카 등 지역 관광지를 활용한 콘 텐츠를 설계하고 이를 통해, 관광 정보, 가상관광체험, 현장 방문 시 활용할 수 있는 인 센티브 등을 제공한다. 특히 가상관광 체험은 게임적 요소를 적용하여 관광객이 주어진 퀘스트를 수행하여 관광지를 체험하도록 하고 미션을 완료하는 경우 할인쿠폰, 지역화폐 등의 인센티브를 보상으로 제공한다.

본 사업의 기대 효과는 청년층의 국내관광에 대한 관심을 지속적으로 환기하는 것으 로 코로나19 상황 하에서 가상 세계를 통한 국내관광 콘텐츠 노출과 상호작용을 통해 효과의 확대 재생산을 기대할 수 있다. 두 번째 효과는 국내관광에 대한 가상의 경험을 통해 청년층이 국내관광, 특히 지역 관광 목적지에 대해 가지고 있는 심리적 제약요인을 완화하는 것이다. 관광객은 가상관광체험 과정에서 퀘스트 수행을 통해 교통, 숙박, 편 의시설 등 지역관광 정보를 제공받으며, 실제 지역 방문시 해당 정보를 활용할 수 있다.

[그림 5-6] 메타버스 연계 홍보·마케팅 사례

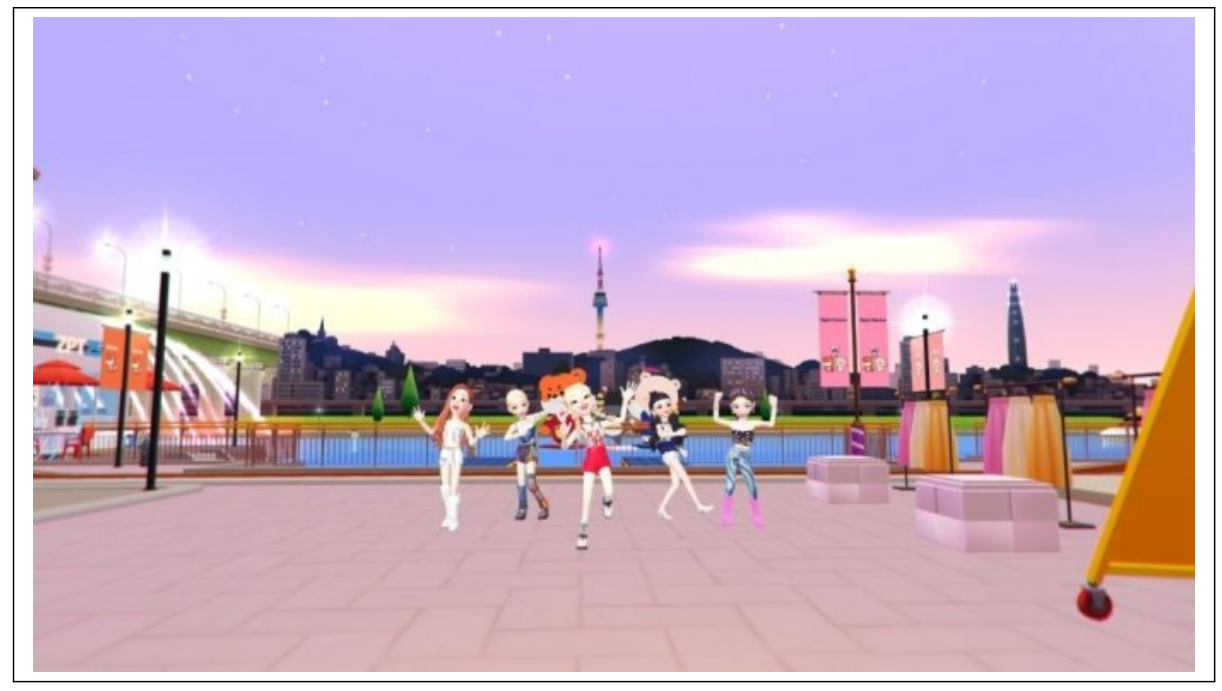

자료: 한국관광공사 


\section{3. 청년관광 인프라 개선}

\section{가. 지역관광 공유 자동차 이용 편의시설 지원}

1) 추진배경

본 연구의 조사 결과 관광 목적지 내 교통수단 불편이 청년층의 국내관광 주요 제약요 인으로 확인되었다. 청년층은 경제적인 요인에 의해 대중교통에 대한 이용률이 상대적으 로 높은 편이지만 빠르고 편리한 국내관광이 가능하고 자유로운 일정 진행이 용이한 자 동 이용에 대한 높은 수요를 가지고 있다. 그러나 청년층은 대부분 학생 또는 사회초년 생의 신분으로 자가용 보유 비율이 낮아서, 렌터카 이용을 현실적인 대안으로 꼽고 있으 나 사군 단위 관광 목적지를 방문하는 경우 이용 가능한 렌터카 공급이 제한적이며, 가 격 또한 높아 경제적 부담을 느끼고 있었다. 특히, 상당수의 국내 관광 목적지는 관광 매력물의 집적도가 낮으며, 지역 내에서 또는 인접 시군으로의 이동을 통한 연계 관광 필요성이 존재하나 렌터카의 경우 일반적으로 대여한 장소를 통해 반납해야 하는 사업 구조를 가지고 있기 때문에 자유로운 일정 진행을 선호하는 청년층은 렌터카 이용에 불 편함을 느끼고 있다.

따라서 지역 관광 활성화를 위한 인프라 구축의 맥락에서 '지역관광 공유 자동차 이용 편의시설 구축 지원 사업 의 추진의 필요성이 있다. 다만 공유 자동차 사업은 민간부분 의 사업 영역으로 정부의 지원은 관광교통 취약 지역 내 관광목적 공유 자동차 도입 및 스테이션 구축을 위한 지원, 청년층 관광 공유 자동차 이용 시 인센티브 지원 등에 한정 될 필요성이 있다.

\section{2) 추진내용}

본 사업의 추진은 지역 관광 공유자동차 구축 지원 사업의 타당성 검토를 위한 학술연 구 용역, 시범사업을 위한 사업자의 선정, 사업 추진의 단계로 진행될 필요성이 있다.

우선 시범사업의 추진을 위해 학술연구용역을 통해 국토부 및 관련 사업체 등 관계기 관 의견 조사, 공유 자동차 이용 실태 조사, 공유 자동차 도입 선호 지역 조사, 국내외 사례 분석, 운영 방식에 대한 선호도 조사, 공유 자동차 도입에 따른 교통 수급분석 등 실시한다. 
시범사업의 방식은 기존 공유차 사업과 같이 시간단위 차량 공유 방식을 기본으로 하 되, 정책 목적을 이용 가능 지역을 관광교통 취약지역으로 한정하는 방안이 검토 되어야 할 것이다. 또한 청년층이 공유 자동차에 편리하게 접근하여 이용하고 반납할 수 있도록 지역 내 주요 출입지점, 관광지 등을 중심으로 복수의 공유 자동차 스테이션을 구축하기 위한 방안이 모색되어야 한다. 이를 위해서는 현재 다수의 지자체에서 시행하고 있는 공유 자전거, 공유 킥보드 사업의 운영 방식을 참고할 필요성이 있다.

\section{〈사례〉 서울자전거: 따릉이}

따릉이는 누구나 쉽고 편리하게 이용할 수 있는 저탄소 이용수단을 목표로 도입되었다. 따릉이는 무인 정류 장 형태의 대여소를 통해 누구나 자전거를 이용할 수 있으며, 대여소는 지하철 출입구, 버스정류장, 주택단 지, 관공서, 학교, 은행 등 접근이 편리한 주변 생활시설 및 통행장소를 중심으로 운영되고 있다. 대여소가 설치된 곳 어디에서나 ‘따릉이 앱’을 통해 자전거를 대여하고 반납할 수 있다.

청년층 공유 자동차 이용시 인센티브를 제공하기 위한 방안으로는 기존에 지자체에서 운영하고 있는 관광교통패스와의 연계 및 지자체별 한달 살기 프로그램과의 연계를 고 려할 수 있다. 이들 사업은 타 지역에서 지역을 방문한 관광객을 대상으로 지역 관광사 업체 이용 시 할인 혜택을 제공하고 있는데, 혜택 제공의 대상에 관광 공유 자동차를 포함하는 것만으로도 청년층이 합리적인 비용으로 지역 관광 활동에 참여할 수 있는 기 회를 제공할 수 있을 것으로 기대된다.

\section{나. 가족 친화 관광 인프라 조성 지원}

1) 추진배경

본 연구 결과 청년층 내 여성, 30대, 기혼, 자녀동반 가구 등은 평소 국내여행 활동이 활발한 계층으로 확인되었다. 그러나 국내여행 시 영유아 등 동반가족을 위한 편의시설 부족을 불편 요인 꼽고 있었으며, 국내관광 개선사항으로 유아동반 관광객 편의시설 확 충에 대한 선호가 높은 것으로 나타났다. 특히, 코로나19 확산 이후 안전에 대한 우려와 로 편의시설 부족으로 국내여행 활동이 급격히 위축된 것으로 확인되었다.

특히 우리 정부는 청년층의 출산을 장려하고 육아를 지원하는 정책 기조를 확대하고 있으며, 생애주기별 관광지원 정책 기조를 통해 국민 누구나 관광을 향유할 수 있는 환 
경을 조성하는 것을 정책 목표로 하고 있다. 따라서 가족 친화 관광 인프라 조성을 지원 함으로써 영유아를 비롯하여, 고령층, 신체적 취약 계층 등을 동반한 가족여행에 대한 제약을 해소하기 위한 노력을 기울일 필요성이 있다.

\section{2) 추진내용}

본 사업의 추진은 (가칭) 가족 친화 관광사업체 인증 제도를 시행하는 것으로 문체부 공모를 통해, 숙박, 유원시설 등을 중심으로 가족 친화 관광사업체를 지정하는 것이다. 가족 친화 관광사업체로 인증받기 위해서는 관광사업체가 영유아, 고령층, 신체적 취약 계층 등을 위한 시설을 구축하고 서비스를 제공하기 위한 전담 인력을 배치하여 운영해 야 한다.

가족 친화 관광사업체 공모에 선정된 업체는 지정업체로서 문화체육관광부 및 유관기 관의 홍보 채널을 통한 노출이 가능하며, 관련 친화 인프라 구축을 및 개보수를 위한 자금을 지원받는다. 또한 관광기금 융자 등에 있어서 추가적인 인센티브를 제공 받을 수 있다.

\section{다. 가칭 ‘청년 복합 게스트 하우스’ 추진}

\section{1) 추진배경}

본 연구 결과 청년층이 평소 국내여행 시 비용 부담이 가장 크다고 생각한 항목은 단 연 숙박비였다. 펜션이나 호텔은 편의성과 시설이 우수하기는 하지만 가격대가 높으며 민박은 저렴하기는 하지만 청년들이 선호하지는 않는다. 청년들은 숙박 장소도 특색이 있고, 주위 관광지로 이동하기에도 편한 장소를 원한다. 게스트하우스가 이러한 청년들 의 취향(주위 관광지로 이동하기 편하고 20-30대 청년층 교류 장소로 기능)에 부합하는 형태이지만 제주도와 같은 지역에만 몰려있다는 지역적 한계를 가지고 있다.

또한 최근 지자체들이 경쟁적으로 시행하고 있는 체류형 ‘한달살기’ 관광지원 사업에 서도 지자체들은 단순히 경비지원에만 그치고 숙소 구하기와 생활 정보 등에 대해서는 별 다른 지원이 없어 제주도와 같은 지역을 제외하고는 적당한 숙소를 찾는 것이 여행자 들에게 부담이 되고 있다. 


\section{2) 추진내용}

청년층의 숙박비 부담을 경감해주고 청년 여행자들의 교류의 장이 될 수 있는 가칭 '청년 복합 게스트하우스 공모사업’을 추진한다. 동 사업은 지자체 대상 공모사업으로 실시하며 새로운 시설을 건축하는 것보다는 청년들이 선호하는 이동 편의성을 갖추어야 하므로 도심 내 유휴 건물을 재활용하는 것을 추천한다.

또한 이 게스트 하우스는 단순히 단기 청년 여행자들을 위한 숙소뿐이 아니라 청년들 의 지역 내 체류형 관광을 위해서 종합 정보 제공센터 및 장기 숙소로도 활용할 수 있도 록 한다. 아울러 향후 지역 워케이션을 대비하여 공유 비즈니스 센터의 공간도 확보하여 복합 기능을 가진 ‘복합 게스트하우스'가 될 수 있도록 한다.

동 사업은 지자체 대상 공모사업으로 추진하며 문체부와 지자체 매칭 펀드 방식으로 추진한다.

〈표 5-5〉 가칭 '청년 복합 게스트하우스' 사업 개요

\begin{tabular}{c|l}
\hline 구분 & \multicolumn{1}{c}{ 내용 } \\
\hline \multirow{3}{*}{ 목적 } & $\begin{array}{l}\text { - 국내여행 청년들의 경제적 부담을 덜어주고 교류할 수 있는 숙박 공간 제공 } \\
\text { - ‘한달살이' 와 같은 지역 체류형 여행자에게 기초적 지역생활 정보 제공 } \\
\text { - 워케이션 참가자들을 위한 공유 비즈니스 공간 }\end{array}$ \\
\hline \multirow{3}{*}{ 공간구성 } & $\begin{array}{l}\text { - 숙박공간 - 장단기 지역 청년여행자들을 위한 숙소 } \\
\text { - 교육 및 소통 공간 - 장기 여행자들을 위한 지역 정보 및 교류 공간 } \\
\text { - 공유 비즈니스 공간- 지역 워케이션 참가자 및 지역 청년기업가들을 위한 공유 비즈니스 공간 }\end{array}$ \\
\hline & $\begin{array}{l}\text { - 지자체 공모사업으로 추진(문체부 + 지자체 매칭 펀드 방식) } \\
\text { - 게스트 하우스 시설이 부족한 지역 우선 고려 } \\
\text { - 운영계획 및 프로그램 충실도 고려 }\end{array}$ \\
\hline
\end{tabular}


이상의 국내관광 활성화를 위한 청년 정책 방안을 정리하면 〈표 5-6〉 과 같다.

〈표 5-6〉 국내관광 활성화를 위한 청년관광 정책방안(종합)

\begin{tabular}{|c|c|c|c|}
\hline 기본방향 & 정책방안 & 내용 & 추진주체 \\
\hline \multirow{3}{*}{$\begin{array}{l}\text { 청년관광 } \\
\text { 제도개선 }\end{array}$} & $\begin{array}{l}\text { 근로자휴가 } \\
\text { 지원사업 확대 }\end{array}$ & $\begin{array}{l}\text { - 근로자 휴가지원사업과 지자체 지역방문 관광객 지 } \\
\text { 원사업의 연계를 통하여 지원대상 확대 }\end{array}$ & $\begin{array}{l}\text { 문체부 } \\
\text { 지자체 }\end{array}$ \\
\hline & 워케이션 시범사업 & $\begin{array}{l}\text { - 국내 워케이션 수요조사를 통해 시범사업 추진 } \\
\text { - 근로자 휴가지원사업과도 연계검토 }\end{array}$ & $\begin{array}{l}\text { 문체부 } \\
\text { 기업 및 } \\
\text { 지자체 }\end{array}$ \\
\hline & $\begin{array}{l}\text { 청년문화누리카드 } \\
\text { 도입 }\end{array}$ & $\begin{array}{l}\text { - 청년층 경제부담 경감을 위하여 청년 문화누리카드 } \\
\text { 도입(2022년) } \\
\text { - 도입 시 경제적 취약계층 / 향후 전체 청년층으로 } \\
\text { 확대 추진 }\end{array}$ & 문체부 \\
\hline \multirow{3}{*}{$\begin{array}{l}\text { 청년관광 } \\
\text { 홍보전략 } \\
\text { 개선 }\end{array}$} & $\begin{array}{l}\text { 청년관광 인스타 } \\
\text { 100선 }\end{array}$ & $\begin{array}{l}\text { - 청년층의 SNS 선호취향을 반영한 홍보전략 추진 } \\
\text { - 해시태그를 이용한 공모방식 }\end{array}$ & 문체부 \\
\hline & $\begin{array}{c}\text { 지역관광 TV } \\
\text { 라방(라이브 방송) }\end{array}$ & $\begin{array}{l}\text { - 일방적 정보 전달이 아닌 양방향 소통 방식의 관광 } \\
\text { 홍보전략 } \\
\text { - 라이브 방송을 통한 지역관광 정보 제공 }\end{array}$ & $\begin{array}{l}\text { 문체부 } \\
\text { 지자체 }\end{array}$ \\
\hline & $\begin{array}{c}\text { 메타버스 연계 } \\
\quad \text { 지역관광 } \\
\text { 홍보· 마케팅 지원 }\end{array}$ & $\begin{array}{l}\text { - 가상 지역관광 콘텐츠를 체험 및 상호작용 지원 } \\
\text { - 코로나19 이후 청년층의 국내관광 관심 환기 } \\
\text { - 가상여행을 통한 지역관광 제약요인 완화 }\end{array}$ & $\begin{array}{l}\text { 문체부 } \\
\text { 지자체 }\end{array}$ \\
\hline \multirow{3}{*}{$\begin{array}{l}\text { 청년관광 } \\
\text { 인프라 개선 }\end{array}$} & $\begin{array}{l}\text { 지역관광 공유자동차 } \\
\text { 아용편의 시설지원 }\end{array}$ & $\begin{array}{l}\text { - 교통불편 지역 여행 시 청년들의 렌터카 이용 편의 } \\
\text { 증진 } \\
\text { - 청년층의 지역 내 공유차량 이용실태 조사를 통하 } \\
\quad \text { 여 사업 추진 }\end{array}$ & $\begin{array}{l}\text { 문체부 } \\
\text { 지자체 }\end{array}$ \\
\hline & $\begin{array}{l}\text { 가족친화 관광시설 } \\
\quad \text { 인증사업 }\end{array}$ & $\begin{array}{l}\text { - 안전과 위생에 대한 수요가 높은 영유아 동반 기혼 } \\
\text { 청년층을 위한 인증 } \\
\text { - 가족 친화관광사업체 인증 }\end{array}$ & 문체부 \\
\hline & $\begin{array}{l}\text { 청년 복합게스트 } \\
\text { 하우스 }\end{array}$ & $\begin{array}{l}\text { - 청년층 숙박비 부담 경감 및 장단기 체류형 숙소/ } \\
\text { 정보 제공 및 네트워크 장소/워케이션 참가자를 위 } \\
\text { 한 공유 워크 스페이스 공간 } \\
\text { - 지자체 공모사업으로 진행 }\end{array}$ & $\begin{array}{l}\text { 문체부 } \\
\text { 지자체 }\end{array}$ \\
\hline
\end{tabular}



국내관광 활성화를 위한 청년관광 실태 분석 및 정책방안

제6장

결론 



\section{1. 결론}

청년은 생애주기에 있어서 가장 왕성한 신체적 활동과 사회에 막 진출하기 시작한 중 요한 시점에 있다. 또한 청년세대는 한 사회의 미래를 책임질 세대로서 그 사회의 향후 미래의 발전상을 결정짓는 집단이기도 하다. 청년은 신체적으로는 성인이지만 막 사회에 진출하여 경제적 자립을 이루지는 못한 상태이기 때문에 경제적으로 취약한 상황이다. 특히 최근의 저성장 경제는 청년들의 경제적 문제를 한층 더 어렵게 하고 있다. 이러한 이유로 우리나라 뿐 아니라 전 세계에서 청년 문제에 많은 관심을 기울이고 있으며 다양 한 청년정책을 수립하고 있으며 우리나라도 예외는 아니다.

과거 우리나라의 청년정책은 일자리 창출에 그 방점이 있었고 최근 청년관광 기본계 획 수립으로 청년의 삶 전반으로 청년정책의 범위가 확대되기는 했지만, 여전히 무게 중심은 고용정책에 있다. 이러한 정책기조로 인하여 우리나라 청년관광 정책도 과거에는 청년창업에 주로 관심을 두다가 최근에서야 청년의 국내관광 활성화를 위한 수요 창출 에 신경을 쓰기 시작했다. 그러나 그 예산이 매우 한정적이고 유형이 마케팅과 홍보에 주로 한정되어 있다.

본 연구에서는 이러한 문제점을 인식하고 청년관광 실태분석을 통해 국내관광 활성화 를 위한 청년관광 정책방안을 도출하고자 하였다. 그 목적을 위해 국민여행 실태조사 분석 및 설문조사, 청년층 FGI 실시, 일본의 청년관광 사례조사 등을 통해 청년관광의 제약요인을 분석하고 청년층의 수요를 반영한 제도개선, 청년 관광 취향에 맞는 홍보전 략 수립, 청년층 불편을 경감하는 인프라 개선의 정책방향에 따른 각각의 과제들을 제시 하였다.

\section{2. 정책 제언}

그동안 우리나라 국내관광정책에서는 청년계층에 대하여 크게 정책적 관심을 두지 않 았다. 이러한 이유는 청년층은 국내여행보다 국외여행을 선호한다는 특성 때문에 청년관 광정책은 우리나라 청년층의 국내여행 활성화 보다는 해외관광객의 방한 유치에 좀 더 관심이 컸기 때문이다. 그러나 코로나19로 인하여 국제여행이 실질적으로 불가능해지면 
서 국내여행에서 청년층의 영향과 활동이 매우 커진 것을 확인할 수 있었다. 코로나 전 과 후를 비교한 세대 별 소비지출에서도 청년층은 여행소비가 국외에서 국내로 이동하 였고, 규모 축소가 크지 않았다. 또한 가장 적극적으로 국내여행에 참여하고 있다는 것 도 확인할 수 있었다.

코로나19가 생각보다 장기화되면서 청년층의 국내여행 활동이 당분간은 지속될 것으 로 예상되는 점을 감안할 때, 현 시점은 우리나라 청년들의 국내여행에 대한 관심을 좀 더 확산시키는데 역설적으로 좋은 기회가 될 수 있다. 청년은 여행에 대한 욕구가 강하 고, 또한 청년시기에 경험한 여행들은 향후의 여행경험과 취향에도 계속 영향을 미칠 수 있다. 이러한 청년시기 여행의 중요성을 고려하여 정부는 청년의 국내관광 참여를 확산시키기 위하여 정책적 관심을 지속적으로 가져야 할 것이다. 


\section{참고문헌}

- 관계부처 합동(2017.12.18.), 「관광진흥 기본계획」.

- 경향신문(2021,04.26), "부모보다 가난한 첫 세대' 청년층, 팬데믹에 더 아프다“ http://news.khan.co.kr/kh_news/khan_art_view.html?art_id=202104261651 001\#csidxf7a9bfe185bdd46bfeeaa4e7d236faf.

- 국가법령정보센터 홈페이지, https://www.law.go.kr/.

- 대학내일20대연구소(2019), ‘밀레니얼-Z세대트렌드 2020」. 서울: 위즈덤하우스.

- 문화체육관광부(2020), 「2019년 국민여행조사 보고서」.

(2020.12.30.), 문체부, '문화가 있는 청년의 삶' 중점 추진(보도자료).

$\bullet$ (2021), 「2020년 국민여행조사 보고서」.

- 심혜정(2019), "연령-소득 프로파일(age-earnings profile) 추정을 통한 세대 간 소 득격차 분석: 경제학공동학술대회-한국재정학회 분과회의.

- 이원희·박주영·조아라(2019), 관광 트렌트 분석 및 전망: 2020-2024」. 서울: 한국문 화관광연구원.

- 와카야마 워케이션 홈페이지, https://wave.pref.wakayama.lg.jp/020400/ workation/index.html.

- 우리금융연구소(2021a), 세대별 온라인 소비행태 변화와 시사점. 우리금융연구소.

- 는 (2021b), 2021년 비즈니스트렌드. 우리금융연구소.

- 이수현(2019), 한국청년들의 여행경험에 관한 연구. 여가학연구, 17(1): 21-47, 미래 정치연구소.

- 일본 관광청(2020), 「여행 - 관광 소비 동향 조사」.

- (2021), 「워케이션 조사보고서: “新たな旅のスタイル(새로운 여행스타일)”」.

- 일본 관광청(観光庁) 홈페이지, https://www.mlit.go.jp/kankocho/ news05_000150.html.

- 조아라·김형종(2019), 「국민의 해외여행 동향분석」. 서울: 한국문화관광연구원.

- 제프 프롬 \& 앤지 리드(2018), 〈Z세대가 온다〉. 
- 청년정책조정위원회(2020), 제1차 청년정책기본계획.

- 통계청, 각년도「경제활동인구조사」

- 파이낸셜뉴스(2021.05.12.), "부모보다 가난해지는 MZ 세대“ https://www.fnnews.com/news/202105121506483868.

- 하나은행 하나금융경영연구소(2021), 세대별 온라인 소비행태 변화와 시사점.

- 한국관광공사(2018), 「관광교통패스 도입 방안 연구」, 원주: 한국관광공사.

$\cdot$ (2020),「근로자휴가지원사업 성과분석 및 발전방안연구」, 원주: 한국관 광공사.

(2021), 「빅데이터에 남겨진 세대별 여행기록」, 원주: 한국관광공사.

- 한국관광공사 Youtube 채널 "대한민국 구석구석".

- 한국일보(2021.04.28.), "일본의 젊은이들은 왜 소비를 멀리할까?" https://www.hankookilbo.com/News/Read/A2021042613320005265.

- 허석재(2015), 세대연구의 경향과 쟁점. 미래정치연구, 5(1): 21-47, 미래정치연구소.

- 홍춘욱·박종훈(2019), 「밀레니얼 이코노미」.

- Deloitte Development LLC(2019), [Deloitte Global Millennial Survey].

- Hotel \& Restaurant(2020.09.), 전복선 칼럼: ‘워케이션’ 으로 새로운 돌파구 모색하 는 일본의 관광산업.

- Huang, Songshan \& Chen, Ganghua(2018). Perceived Personal Development Benefits from Backpacking: A Cross-Cultural Comparison. Tourism Culture \& Communication, 18; 275-286.

- KOTRA(2021), 트렌드 보고서, “일본 워케이션 시장동향”.

- UNWTO \& WYSE(2011), 「The Power of Youth Travel.

- WYSE Press release(2020), "The Youth Travel Industry and COVID-19", https://www.wysetc.org/research/wyse-covid-19-travel-business-impact-se ries/.

・国土交通省·観光庁(2011).「若者旅行振興の必要性について」. 


\title{
ABSTRACT
}

\section{A Study on the Current Trend of Youth Tourism and Policy Measures to Revive Domestic Tourism}

\author{
Yongseok Shin $\cdot$ Hyunsoo Kang
}

Youth is the period of being engaged in the most vigorous physical activity in the human life cycle, and also an important time to begin their career journey. In addition, the youth generation, a generation responsible for the future of a society, is a group that determines the future development of the society. In this regard, countries around the world are focusing more attention on social issues for young people and various youth policies are being formulated and Korea is no exception.

In the past, Korea's youth policy was focused on job creation. Notwithstanding that the scope of youth policy has been expanded to the overall life of young people with the recent development of the Tourism master plan for youth, the main attention is still on the employment policy. With such policy directions, youth tourism policy in Korea focused mainly on youth entrepreneurship, but just recently began to put emphasis on creating demand for youth tourism in Korea. However, the related budget is very tight and the policy implementation is mainly limited to marketing and public relations.

Based on these considerations, this study aims to derive tourism policy measures for youth to invigorate domestic tourism by analyzing the current situation of youth tourism. In order to achieve the purpose of the study, the characteristics of the youth tourism and constraining factors for domestic tourism are analyzed by examining National Travel Survey, conducting FGI (Focus Group Interview) with the youth group, and carrying out a case study on the Japanese youth tourism. The 
study proposes each task in accordance with the policy directions of the institutional improvement reflecting the demand of the youth, development of a marketing strategy considering the preferences of young tourists, and enhancement of infrastructure to mitigate the inconvenience of young people.

Thus far, the domestic tourism policy of Korea has made low political attention to the youth group. This is due to the characteristic of young tourists preferring overseas travel rather than domestic travel, hence the youth tourism policy was more focused on attracting foreign youth to Korea than on invigorating domestic travel by young people. However, as international travel became practically impossible due to the outbreak of COVID-19, it is witnessed that the influence and activities of young people on domestic travel have greatly increased. In terms of consumption expenditure by generation compared before and after the COVID-19 outbreak, the tourism consumption of the youth group has shifted from overseas to domestic travel, and there was no significant reduction in the consumption. It is also found that they are most actively engaged in domestic travel.

Given that the COVID-19 pandemic continues longer than expected, domestic travel by young tourists will continue to be strong for the time being. Now is therefore an opportune time to further attract young people's interest in domestic travel. Young people have a strong desire for travel, and the trips experienced during their youth would have a continuous effect on their future travel experiences and preferences. Considering the significance of youth tourism, the government should pay continuous attention to policies to expand youth participation in domestic tourism.

\section{Keywords}

Revitalizing domestic tourism, Domestic tourism, Youth, Young people, Youth tourism, Youth tourism policy 


\section{부록}

설문지 



\section{부록}

\section{청년층 국내관광 특성 심층조사}

\section{SQ. 응답자 정보}

SQ1. 귀하의 성별은 무엇입니까?

(1) 남성

(2) 여성

[로직: 만18세 이하, 만 35세 이상 조사 종료]

SQ2. 귀하의 나이(연세)는 만으로 어떻게 되십니까?

만()세

SQ3. 귀하께서 현재 거주하고 계신 지역은 어디입니까?
(1) 서울
(10) 충북
(2) 부산
(11) 충남
(3) 대구
(12) 전북
(4) 인천
(13) 전남
(5) 광주
(14) 경북
(6) 대전
(15) 경남
(7) 울산
(16) 제주
(8) 경기
(17) 세종
(9) 강원

SQ4. 귀하께서는 2019년 1월 1일부터 현재까지 국내여행을 다녀온 경험이 있습니까?

(1) 있다 $\rightarrow$ SQ5로 이동

(2) 없다 $\rightarrow$ 조사종료 
SQ5. 귀하의 직업은 무엇입니까? 학업과 경제활동을 병행하는 경우 주업에 응답해 주십시오.
(1) 대학(원)생
(4) 프리랜서
(2) 직장인
(5) 무직
(3) 자영업
(6) 기타)

SQ5-1. (SQ5=11) 응답자만 응답) 귀하께서는 2019년 1월 1일부터 현재까지 필요한 경비(교 육비, 용돈 등)를 마련하기 위해 경제활동(아르바이트 등)을 수행한 경험이 있습니까?

(1) 예

(2) 아니오

\section{I. 국내여행 특성}

Q1. 가장 최근에 다녀온 국내여행은 당일여행입니까? 숙박여행입니까?
(1) 당일여행
$\rightarrow$ 문2로 이동
(2) 숙박여행
$\rightarrow$ 문1-1로 이동

Q1-1. 가장 최근에 다녀온 국내여행 기간은 며칠입니까?

() 박 () 일

Q2. 가장 최근에 다녀온 국내여행 시, 연차(휴가)를 사용하셨습니까?
(1) 사용하지 않았음
$\rightarrow$ 문3으로 이동
(2) 사용하였음
$\rightarrow$ 문2-1로 이동

Q2-1. 사용한 연차(휴가) 기간은 어떻게 되십니까?

() 일

Q3. 가장 최근에 다녀온 국내여행 목적지는 어디입니까? 여러 곳을 방문한 경우 가장 오 래 머문 곳 1 개만 응답해 주십시오.
() 시/도
() 시/군/구 
Q4. 방금 응답한 [제시: Q3=시/군/구 응답값]을/를 여행 목적지로 선택한 이유는 무엇입 니까? 우선 순위대로 3 개만 골라 주십시오.

(1) 가까운 이동거리 때문에

(2) 가고 싶은 맛집이 있어서

(3) 특가 프로모션 때문에

(4) 고급스럽거나 특색있는 숙박시설 때문에

(5) 체험거리가 다양하기 때문에

(6) 전망, 사진촬영 때문에

(7) 해당 지역만의 고유한 특성을 느끼기 위해서

(8) 가성(심)비 있는 여행 목적지이기 때문에

(9) 가족(친인척), 지인 등을 만나기 위해서

(10) 과거 방문 시 좋았던 기억 때문에

(11) 영유아 동반 친화적인 여행지이기 때문에

(12) 기타0

\section{Q5. 가장 최근에 다녀온 국내여행 목적지까지 출발지에서 얼마나 걸리셨습니까?}

※ 당일여행: 집에서 첫 번째 방문한 관광지까지의 이동시간 기준

※ 숙박여행: 집에서 숙소 혹은 첫 번째 방문한 관광지까지의 이동시간 기준

(1) 2 시간 이하

(2) 3-4시간

(3) 5-8시간

(4) 8 시간 이상

Q6. 가장 최근에 다녀온 국내여행은 누구와 햠께 하셨습니까? 해당 되는 것을 모두 골라 주십시오 $※$ 영유아 $=$ 만3세 이하, 어린이 $=$ 만13세 이하
(1) 혼자[중복선택불가]
(2) 가족/친지(영유아/어린이 미동반)
(3) 가족/친지(영유아/어린이 동반)
(4) 친구
(5) 연인
(6) 단체/모임(산악회, 동호회 등)
(7) (직장)동료
(8) 기타) 
Q7. 가장 최근에 다녀온 국내여행 본인 몫의 비용은 어떻게 마련하셨습니까? 우선 순위대로. 2개까지 골라 주십시오.

(1) 전액 본인 스스로 경제활동을 통해 마련

(2) 전액 또는 일부 경비를 가족/친지의 지원을 통해 마련

(3) 전액 또는 일부 경비를 가족/친지 외 지인의 지원을 통해 마련

(4) 전액 또는 일부 경비를 소속 단체/모임의 지원을 통해 마련

(5) 전액 또는 일부 경비를 정부/지자체의 지원 프로그램을 통해 마련

(6) 기타)

Q8. 가장 최근에 다녀온 국내여행 시, 이용한 교통수단은 무엇입니까? 해당 되는 것을 모두 골라 주십시오.
(1) 자가용
(6) 항공기
(2) 렌터카
(7) 시내/시외/고속버스
(3) 기차(KTX, ITX, 새마을 등)
(8) 전세버스
(4) 지하철
(9) 선박
(5) 택시
(10) 기타)

Q8-1. (Q8=(1), (2) 응답자만 응답) 가장 최근에 대녀온 국내여행 시 자가용렌터카를 이용한 이유 는 무엇입나까? 가장 주된 야유 1개만 골라 주십시오

(1) 국내여행 목적지까지 쉽고 빠르게 이동할 수 있기 때문에

(2) 자가용/렌터카를 이용하는 것이 대중교통을 이용하는 것보다 경제적이기 때문에

(3) 상황에 따라 자유로운 여행일정 진행이 가능하기 때문에

(4) 다양한 관광지를 방문할 수 있기 때문에

(5) 기타)

Q8-2. (Q8=(1), (2) 이외 응답자만 응답) 가장 촤근에 대녀온 국내여행 시 대중교통을 이용한 이유 는 무엇입니까? 가장 주된 이유 1 개만 골라 주십시오

(1) 국내여행 목적지까지 쉽고 빠르게 이동할 수 있기 때문에

(2) 대중교통을 이용하는 것이 자가용/렌터카를 이용하는 것보다 경제적이기 때문에

(3) 와이파이 이용, 스마트폰 충전 등 편의성 때문에

(4) 대중교통만의 특별한 여행경험(감성)을 느낄 수 있기 때문에

(5) 운전면허가 없기 때문에

(6) 기타) 
Q9. (Q1=(2) 응답자만 응답) 가장 최근에 다녀온 국내여행 시, 이용한 숙박시설은 무엇입니까? 해당되는 것을 모두 골라 주십시오.
(1) 호텔
(2) 콘도미니엄(리조트, 콘도)
(3) 모텔/여관
(4) 펜션
(5) 민박(도시형/농촌형)
(6) 찜질방
(7) 게스트하우스
(8) 가족/친지/지인집

(9) 야영/캠핑/차박 등

(10) 자연휴양림 내 숙박시설

(11) 전통 한옥 숙박시설

(12) 연수원/수련원

(13) 유스호스텔

(14) 공유 숙박(에어비앤비 등)

(15) 무박 여행

(16) 기타)

Q9-1. (Q1=(2) 응답자 and Q9=88, (15) 이외 응답자만 응답) 방금 응답하신 숙박시설은 어디 에서 구매/예약하셨습니까? 해당되는 것을 모두 골라 주십시오.

(1) 숙박시설 공식 채널(현장, 전화, 홈페이지 등)

(2) 오프라인 여행사

(3) 온라인 여행사(인터파크투어, 마이리얼트립, 트립닷컴 등)

(4) 숙박예약 플랫폼(야놀자, 호텔스닷컴, 부킹닷컴, 호텔스 컴바인, 아고다 등)

(5) 포털사이트(네이버 호텔 예약 등)

(6) 소셜 커머스(쿠팡, 위메프, 카카오 핫딜 등)

(7) 기타()

Q9-2. (Q1=(2) 응답자 and $\mathrm{Q9=88,} \mathrm{(15)} \mathrm{이외} \mathrm{응답자만} \mathrm{응답)} \mathrm{방금} \mathrm{응답하신} \mathrm{숙박시설을}$ 구매/예약할 때, 중요하게 고려한 것은 무엇입니까? 우선순위대로 3개만 골라 주십시오.
(1) 비용/가격
(8) 객실안전 및 보안상태
(2) 객실 청결 및 위생상태
(9) 할인혜택 유무
(3) 교통 편리(위치)
(10) 조식 우수성
(4) 주변 볼거리 및 놀거리
(11) 수영장 우수성
(5) 주변 먹거리
(12) 피트니스 우수성
(6) 화장실 및 샤워시설 수준
(13) 기타()
(7) 숙박시설 인테리어 
Q10. 귀하께서 평소 다른 여가 활동과 비교해 국내여행을 하는 주된 이유는 무엇입 니까? 우선순위대로 3 개만 골라 주십시오.

(1) 지역별 먹거리와 맛집을 즐길 수 있기 때문에

(2) 아름답고 이색적인 장소를 배경으로 사진을 촬영할 수 있기 때문에

(3) 짧은 휴가기간을 이용하여 여행이 가능하기 때문에

(4) 계획 없이 즉흥적으로 국내여행이 가능하기 때문에

(5) 가보고 싶었던 관광지(유원지 포함)를 다녀오기 위해서

(6) 국내여행은 어린 자녀와 함께 할 수 있는 활동이기 때문에

(7) 일상에서 벗어난 경험을 할 수 있기 때문에

(8) 힐링, 휴식 등을 경험할 수 있기 때문에

(9) 가족, 친지 등을 만날 수 있기 때문에

(10) 기타()

Q11. 귀하께서 국내여행 욕구를 불러 일으키는(가고 싶게 만드는) 디지털 콘텐츠 유형은 무 엇입니까? 우선순위대로 3 개만 골라 주십시오.

(1) 여행지의 상징적 이미지를 시각화 하고 있는 영상 광고

(2) 여행지의 풍광과 매력물의 정보를 제공하는 다큐멘터리 형식의 영상물

(3) 크리에이터가 국내여행 과정을 소개하는 여행후기 형식의 영상물

(4) 관광 매력물의 사진과 해시태그로 구성된 SNS 콘텐츠

(5) 관광 매력물의 이미지와 단문의 텍스트 정보를 도식화하여 3-4장의 슬라이드

(5) 형태로 소개하는 관광정보 콘텐츠

(6) 사진(또는 동영상)을 포함한 장문의 텍스트로 설명된 여행 후기 콘텐츠

(7) 단문의 텍스트를 통해 개별 여행지(또는 여행상품)에 대해 평가하는 후기 콘텐츠

(8) 기타)

Q12. 귀하가 평소 국내여행을 계획할 때, 주로 이용하는 여행정보 디지털 콘텐츠의 유형은 무엇입니까? 정보를 많이 얻은 순서대로 3 개만 골라 주십시오.

(1) 여행지의 상징적 이미지를 시각화 하고 있는 영상 광고

(2) 여행지의 풍광과 매력물의 정보를 제공하는 다큐멘터리 형식의 영상물

(3) 크리에이터가 국내여행 과정을 소개하는 여행후기 형식의 영상물

(4) 관광 매력물의 사진과 해시태그로 구성된 SNS 콘텐츠

(5) 관광 매력물의 이미지와 단문의 텍스트 정보를 도식화하여 3-4장의 슬라이드 형태로 소개하는 관광정보 콘텐츠

(6) 사진(또는 동영상)을 포함한 장문의 텍스트로 설명된 여행 후기 콘텐츠

(7) 단문의 텍스트를 통해 개별 여행지(또는 여행상품)에 대해 평가하는 후기 콘텐츠

(8) 기타) 
Q12-1. [제시: Q12=1순위 응답]을 조로 이용하는 이유는 무엇입니까?

Q13. (Q13=(1), (2) 응답자만 응답) 귀하께서는 다녀온 여행 경험을 온라인에 공유하고 있습니까?

(1) 매번 다녀온 여행에 대해 공유한다

(2) 여행이 매우 좋거나 혹은 나쁜 경우에만 공유한다

(3) 공유한 적이 없다

(4) 기타)

Q13-1. (Q13=11, (2) 응답자만 응답) 귀하께서 다녀온 국내여행의 경험을 공유하는 방 법은 무엇입니까? 자주 이용하는 순서대로 3 개만 골라 주십시오.

(1) 여행지의 상징적 이미지를 시각화 하고 있는 영상 광고

(2) 여행지의 풍광과 매력물의 정보를 제공하는 다큐멘터리 형식의 영상물

(3) 크리에이터가 국내여행 과정을 소개하는 여행후기 형식의 영상물

(4) 관광 매력물의 사진과 해시태그로 구성된 SNS 콘텐츠

(5) 관광 매력물의 이미지와 단문의 텍스트 정보를 도식화하여 3-4장의 슬라이드 형태로 소개하는 관광정보 콘텐츠

(6) 사진(또는 동영상)을 포함한 장문의 텍스트로 설명된 여행 후기 콘텐츠

(7) 단문의 텍스트를 통해 개별 여행지(또는 여행상품)에 대해 평가하는 후기 콘텐츠

(8) 기타)

Q13-2. 귀하께서 다녀온 여행 경험을 온라인에 공유하는 이유는 무엇입니까? 


\section{ㅍ. 국내여행 제약}

Q14. 귀하께서 다음 국내여행 제약 요인에 대해 얼마나 동의 하십니까?

\begin{tabular}{|c|c|c|c|c|c|}
\hline 구분 & $\begin{array}{c}\text { 전혀 } \\
\text { 그렇지 } \\
\text { 않다 }\end{array}$ & $\begin{array}{l}\text { 그렇지 } \\
\text { 않다 }\end{array}$ & $\begin{array}{l}\text { 보통 } \\
\text { 이다 }\end{array}$ & 그렇다 & $\begin{array}{c}\text { 매우 } \\
\text { 그렇다 }\end{array}$ \\
\hline 1. 국내여행에 대한 흥미가 없다 & (1) & (2) & (3) & (4) & (5) \\
\hline 2. 국내여행을 함께 할 사람이 없다 & (1) & (2) & (3) & (4) & (5) \\
\hline 3. 국내여행을 할 시간이 없다 & (1) & (2) & (3) & (4) & (5) \\
\hline $\begin{array}{l}\text { 4. 국내여행을 위한 관광 인프라(교통/숙박 } \\
\text { 등)가 불편하다 }\end{array}$ & (1) & (2) & (3) & (4) & (5) \\
\hline 5. 국내여행을 할 경제적 여유가 없다 & (1) & (2) & (3) & (4) & (5) \\
\hline 6. 국내여행에 대한 정보가 부족하다 & (1) & (2) & (3) & (4) & (5) \\
\hline 7. 국내여행을 하는 것은 안전하지 않다 & (1) & (2) & (3) & (4) & (5) \\
\hline
\end{tabular}

Q15. (Q14-1=(4), (5) 응답자만 응답) 귀하께서 국내여행에 대한 흥미가 없다고 응답하 신 이유는 무엇입니까?

Q16. (Q14-3=(4), (5) 응답자만 응답) 귀하께서 국내여행을 할 시간이 없다고 응답한 이유는 무엇입니까? 우선순위대로 2개만 골라 주십시오.

(1) 학업/취업준비 등에 대한 부담

(2) 국내여행을 위해 휴가를 내기 어려운 직장 분위기

(3) 주5일 근무제 미시행 등 근로시간 부담

(4) 가사노동에 대한 부담

(5) 기타()

Q17. (Q14-4=(4), (5) 응답자만 응답) 국내여행을 위한 관광 인프라 가운데 가장 불편하 다고 생각한 것은 무엇입니까? 우선순위대로 2개만 골라 주십시오.

(1) 관광지역까지 이동할 교통수단

(2) 관광지역 내에서의 이동을 위한 교통수단

(3) 국내 관광객을 위한 숙박시설

(4) 관광 관련 용품을 구압하거나 대여할 수 있는 시설

(5) 영유아, 고령층 등 동반자를 위한 편의 시설 및 서비스

(6) 기타() 
Q18 (Q14-5=44, (5) 응답자만 응답) 귀하께서 평소 국내여행 시, 비용 부담이 크다고 생각한 항목은 무엇입니까? 우선순위대로 2개만 골라 주십시오.
(1) 교통비
(4) 쇼핑비
(2) 숙박비
(5) 입장료/관람료
(3) 식/음료비
(6) 기타()

Q19. 귀하께서는 가장 최근에 다녀온 국내여행 목적지를 향후 1년 이내에 다시 방문할 의 향이 있습니까?

\begin{tabular}{c|c|c|c|c}
\hline $\begin{array}{c}\text { 전혀 그렇지 } \\
\text { 않다 }\end{array}$ & 그렇지 않다 & 보통/반반 이다 & 그렇다 & 매우 그렇다 \\
\hline (1) & (2) & (3) & (4) & (5) \\
\hline
\end{tabular}

Q19-1. (Q19=(1), (2) 응답자만 응답) 다시 방문할 의향이 없다면 이유는 무엇입니까? 우선순위대로 3 개만 골라 주십시오.

(1) 경제적으로 부담되서

(2) 교통 관련 인프라가 불편해서

(3) 숙박시설이 불편해서

(4) 관광객을 위한 편의시설이 부족해서

(5) 지역주민이 불친절해서

(6) 볼거리가 부족해서

(7) 먹거리가 부족해서

(8) 체험활동이 부족해서

(9) 지금까지 가보지 않은 새로운 곳으로 국내여행을 다녀오고 싶어서

(10) 기타()

Q19-2. (Q19=(4), (5) 응답자만 응답) 다시 방문할 의향이 있다면 이유는 무엇입니까? 우선순위대로 3 개만 골라 주십시오.

(1) 경제적으로 부담이 되지 않아서

(2) 교통 관련 인프라가 편리해서

(3) 숙박시설이 편리해서

(4) 관광객을 위한 편의시설이 충분해서

(5) 지역주민이 친절해서

(6) 볼거리가 충분해서

(7) 먹거리가 충분해서

(8) 체험활동이 충분해서

(9) 기타() 


\section{III. 국내여행 평가}

Q20. 2019년 1월 1일부터 현재 귀하께서 경험한 국내여행을 바탕으로 다음 항목에 대해 평가해 주십시오

\begin{tabular}{|c|c|c|c|c|c|}
\hline 구분 & $\begin{array}{l}\text { 전혀 } \\
\text { 그렇지 } \\
\text { 않다 }\end{array}$ & $\begin{array}{l}\text { 그렇지 } \\
\text { 않다 }\end{array}$ & $\begin{array}{l}\text { 보통 } \\
\text { 이다 }\end{array}$ & 그렇다 & $\begin{array}{l}\text { 매우 } \\
\text { 그렇다 }\end{array}$ \\
\hline $\begin{array}{l}\text { 1. 청년(및 동반자)이 이용하기 쉽게 관광정 } \\
\text { 보 제공 채널이 다양하다 }\end{array}$ & (1) & (2) & (3) & (4) & (5) \\
\hline $\begin{array}{l}\text { 2. 청년(및 동반자)이 이용가능한 관광정보의 } \\
\text { 내용이 풍부하다 }\end{array}$ & (1) & (2) & (3) & (4) & (5) \\
\hline $\begin{array}{l}\text { 3. 청년(및 동반자)이 여행하기 쉽게 환경(인 } \\
\text { 프라)이 조성되어 있다 }\end{array}$ & (1) & (2) & (3) & (4) & (5) \\
\hline $\begin{array}{l}\text { 4. 청년(및 동반자)이 여행하기 쉽게 편의시 } \\
\text { 설이 마련되어 있다 }\end{array}$ & (1) & (2) & (3) & (4) & (5) \\
\hline $\begin{array}{l}\text { 5. 방문지에서 청년(및 동반자)이 여행하기 } \\
\text { 쉽게 안내가 이루어진다 }\end{array}$ & (1) & (2) & (3) & (4) & (5) \\
\hline $\begin{array}{l}\text { 6. 환대시설(호텔, 음식점 등)에서 종사자의 } \\
\text { 서비스가 적절하다 }\end{array}$ & (1) & (2) & (3) & (4) & (5) \\
\hline 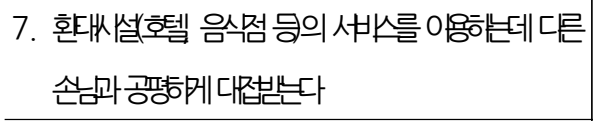 & (1) & (2) & (3) & (4) & (5) \\
\hline $\begin{array}{l}\text { 8. 청년(및 동반자)으로서 선택할 수 있는 여 } \\
\text { 행상품이 다양하다 }\end{array}$ & (1) & (2) & (3) & (4) & (5) \\
\hline $\begin{array}{l}\text { 9. 청년(및 동반자) 관련 여행상품의 가격이 } \\
\text { 적절하다 }\end{array}$ & (1) & (2) & (3) & (4) & (5) \\
\hline $\begin{array}{l}\text { 10. 여행하는데 다른 관광객들의 시선이 불 } \\
\text { 편하다 }\end{array}$ & (1) & (2) & (3) & (4) & (5) \\
\hline $\begin{array}{l}\text { 11. 청년(및 동반자)이 이용할 수 있는 콘텐츠 } \\
\text { (또는 매력물)이 충분하다 }\end{array}$ & (1) & (2) & (3) & (4) & (5) \\
\hline $\begin{array}{l}\text { 12. 청년(및 동반자)에게 국내여행은 안전 } \\
\text { 하다 }\end{array}$ & (1) & (2) & (3) & (4) & (5) \\
\hline
\end{tabular}




\section{IV. 청년층 국내여행 활성화를 위한 개선사항}

청년층 관광저변 확대: 캠페인 등을 통해 청년층의 활동은 학업, 취업, 노동 등 생산 활동에 국한해야 한다는 기존 인식을 해소하고 청년층 관광 향유권의 확대와 당위 성에 대한 긍정적 시선 변화 유도

- 인프라 구축: 청년층 및 동반자가 이용하기에 편리한 청년 친화적인 시설을 구축함

- 서비스 개선: 종업원 교육 등을 통해 연령, 동반자 등에 따른 차별 없이 청년층들에 게 공평한 서비스를 제공하고 청년 관광에 대해 불편한 시선을 느끼지 않도록 함

상품 개발/개선: 청년층의 선호를 고려하여 다양한 관광상품 구성 및 콘텐츠 개발을 통해서 관광상품 선택의 자유를 부여함

Q21. 귀하께서는 청년들의 국내여행 활성화를 위해 다음 사항이 얼마나 중요하다 고 생각하십니까? 2019년 1월 1일부터 현재 귀하께서 경험한 국내여행을 바탕 으로 응답해 주십시오.

\begin{tabular}{l|c|c|c|c|c}
\hline \multicolumn{1}{|c|}{ 구분 } & $\begin{array}{c}\text { 전혀 } \\
\text { 중요하지 } \\
\text { 않다 }\end{array}$ & $\begin{array}{c}\text { 중요하지 } \\
\text { 않다 }\end{array}$ & $\begin{array}{c}\text { 보통 } \\
\text { 이다 }\end{array}$ & $\begin{array}{c}\text { 중요 } \\
\text { 하다 }\end{array}$ & $\begin{array}{c}\text { 매우 } \\
\text { 중요하다 }\end{array}$ \\
\hline 1. 청년층 관광저변 확대 & (1) & (2) & (3) & (4) & (5) \\
\hline 2. 정보제공 확대 & (1) & (2) & (3) & (4) & (5) \\
\hline 3. 인프라 구축 & (1) & (2) & (3) & (4) & (5) \\
\hline 4. 서비스 개선 & (1) & (2) & (3) & (4) & (5) \\
\hline 5. 상품개발/개선 & (1) & (2) & (3) & (4) & (5) \\
\hline
\end{tabular}

[로직: Q21의 항목 5개 로테이션]

Q22. 귀하께서는 청년의 국내여행 활성화를 위해 [제시 Q21-1 TO Q21-5]에서 민 간의 역할이 중요하다고 생각하십니까? 아니면 공공의 역할이 중요하다고 생 각하십니까?

※ 민간부문: 관광, 여행, 숙박 관련 사업체 등

※ 공공부문: 중앙정부, 지방자치단체, 관광 관련 공사, 국책 연구원 등

\begin{tabular}{l|l|l|l|l|l|l}
\hline \multirow{2}{*}{ 민간 } & 매우 & 약간 & 중간 & 약간 & 매우 & \multirow{2}{*}{ 공공 } \\
\cline { 2 - 5 } & & & & & & \\
\hline
\end{tabular}




\section{Q23. 귀하께서는 청년의 국내여행 활성화를 위해 정부가 추진해야 할 정} 책이 무엇이라고 생각하십니까? 우선순위대로 2개만 골라 주십시오.

(1) 대학(원)생 여행경비 지원

(2) 근로자 휴가지원사업 확대(정부와 기업이 함께 근로자의 국내여행 경비를 지원)

(3) 워케이션 제도 도입(휴가지에 머물면서 일을 병행하는 근무형태)

(4) 주 52시간 근무제 등 유연근무제 확대 시행

(5) 비대면 수업, 재택근무 등 확대

(6) 지역 관광지 대중교통 접근성 개선

(7) 유아동반 관광객 편의 시설 확충

(8) SNS 관광지 홍보/마케팅 강화

(9) 청년층이 선호하는 이벤트, 체험활동 등 매력적인 국내관광 상품/서비스 개발

(10) 국내 관광지 바가지요금 개선

(11) 기타()

\section{$\mathrm{DQ}$. 응답자 특성}

DQ1. 귀 가구의(함께 살고 있는 사람) 지난 $\mathbf{1}$ 년 간 월 평균 소득은 어떻게 되십니까? 세금을 포함하여 말씀해 주십시오.

※ 총 소득을 12개월로 나눈 금액으로 응답해 주십시오.

※ 소득은 근로소득, 사업소득, 재산소득, 이전소득, 비경상 소득을 모두 포함하여 말씀해 주십시오.
(1) 소득없음
(7) 500-600만원 미만
(2) 100 만원 미만
(8) 600-700만원 미만
(3) 100-200만원 미만
(9) 700-800만원 미만
(4) 200-300만원 미만
(10) $800-900$ 만원 미만
(5) 300-400만원 미만
(11) 900-1,000만원 미만
(6) 400-500만원 미만
(12) 1,000 만원 이상

$\mathrm{DQ}$ 2. 귀하의 지난 1 년 간 월 평균 소득은 어떻게 되십니까? 세금을 포함하여 말씀해 주십시오.

* 총 소득을 12개월로 나눈 금액으로 응답해 주십시오.

※ 소득은 근로소득, 사업소득, 재산소득, 이전소득, 비경상 소득을 모두 포함하여 말씀해 주십시오.
(1) 소득없음
(7) 500-600만원 미만
(2) 100 만원 미만
(8) $600-700$ 만원 미만
(3) 100-200만원 미만
(9) 700-800만원 미만
(4) 200-300만원 미만
(1) $800-900$ 만원 미만
(5) 300-400만원 미만
(11) $900-1,000$ 만원 미만
(6) 400-500만원 미만
(12) 1,000 만원 이상 
DQ3. 귀하께서는 자가용을 보유하고 계십니까?
(1) 보유
(2) 미보유

DQ4. 귀하께서는 평소 월 평균 소득 중 몇 \%를 국내여행하는데 사용하십니까?

(1) $5 \%$ 미만

(2) $5-10 \%$ 미만

(3) $10-20 \%$ 미만

(4) $20-30 \%$ 미만

(5) $30 \%$ 이상

$\mathrm{DQ} 5$. 귀하의 결혼상태는 어떻게 되십니까?
(1) 기혼
(2) 미혼
(3) 이혼
(4) 기타)

DQ6. 귀하는 자녀가 있습니까?

(1) 있다

(2) 없다

DQ6-1. 자녀가 있다면, 총 몇 명입니까?

총 ()명

DQ6-2. 가장 어린 자녀의 출생연도는 어떻게 되십니까?

() 년 

집필내역

연구책임

신용석 한국문화관광연구원 부연구위원: 제 1 장 제 2 장, 제4장, 제5장 제6장

강현수 한국문화관광연구원 연구원: 제3장, 제4장 1절, 제5장 2절

연구 자문

강성숙 Tezukayama University 교수

박은경 대구대학교 호텔관광학과 교수

여경진 한국방송통신대학교 관광학과 교수

이인재 가천대학교 관광경영학과 교수

이혜정 구미대학교 호텔관광항공서비스과 교수

정란수 프로젝트 수 대표

최승묵 청운대학교 관광경영학과 교수

국내관광 활성화를 위한 청년관광 실태 분석 및 정책방안

발 행 인 김 대관

발 행 처 한국문화관광연구원

서울시 강서구 금낭화로 154

전화 02-2669-9800 팩스 02-2669-9880

http://www.kcti.re.kr

인 쇄 일 2021년 10월 15일

발행 일 2021년 10월 15일

인 쇄 인 (사)한국장애인이워크협회 일자리사업장

I S B N 978-89-6035-878-2 93300

DOI https://doi.org/10.16937/kcti.rep.2021.e16

이 연구보고서를 인용하실 때는 다음과 같은 사항을 기재해 주십시오.

신용석, 강현수(2021), 국내관광 활성화를 위한 청년관광 실태 분석 및 정책방안,

한국문화관광연구원 


\section{OPEN}

한국문화관광연구원

서울특별시 강서구 금낭화로 154

전화 02-2669-9800

팩스 02-2669-9880

www.kcti.re.kr 